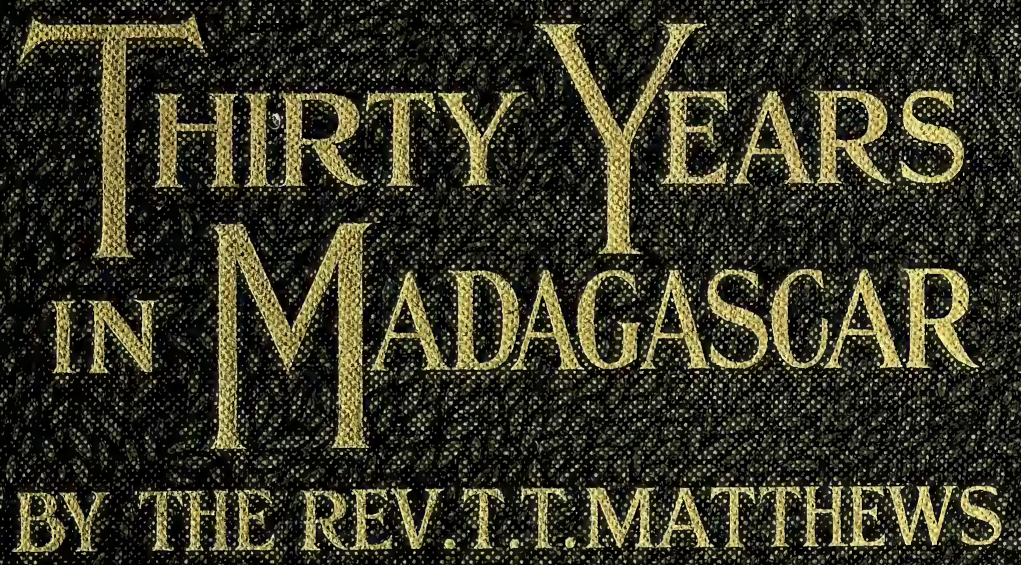




$$
11.5-28
$$


cthpaib Pozs
Deaforth Trtmathomal 6 

THIRTY YEARS IN MADAGASCAR 
OXFORD

HORACE HART, PRINTER TO THE UNIVERSITY 



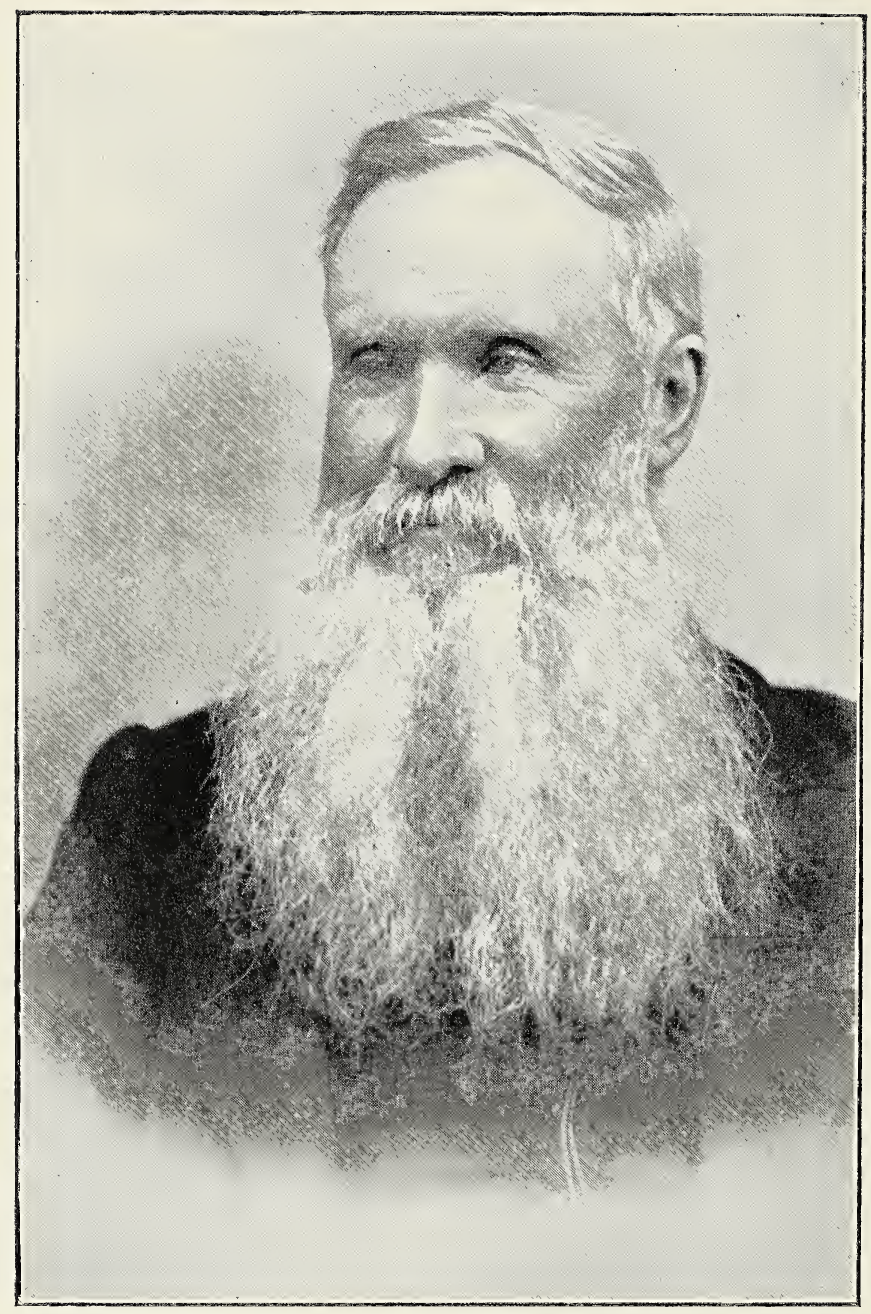

THE REV. T. T. MATTHEWS. 


\section{THIRTY YEARS IN 1 MADAGASCAR}

BY THE REV. T. T. MATTHEWS

OF THE LONDON MISSIONARY SOCIETY

WITH

SIXTY-TWO ILLUSTRATIONS

FROM PHOTOGRAPHS

AND SKETCHES

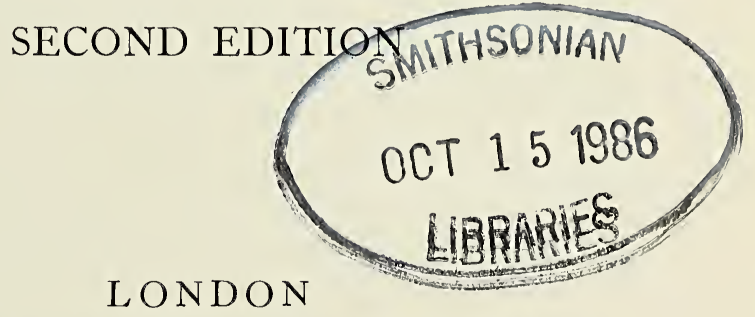

THE RELIGIOUS TRACT SOCIETY

4 BOUVERIE STREET AND 65 ST. PAUL'S CHURCHYARD

I 904 



\section{PREFACE}

FOR the facts of the historical introduction I am mainly indebted to the writings of earlier writers and missionaries, and to unpublished native accounts of the earlier years of the mission and of the persecutions; for mine would have been almost impossible had it not been for the labours of those other workers in the same field, and for the native sources I have mentioned. Without such knowledge as this introduction gives no correct conception can be formed of Madagascar and the Malagasy, of the work done for and among them, the present condition and future prospects of the people, and of the future of Christian work in the island.

I have been also indebted to a long course of reading on mission work at large, and on the work in Madagascar in particular. Much of this has become so mingled with my own thoughts that I cannot now possibly trace all the sources of it; but I have tried, as far as I could, to make acknowledgement of all the sources of information to which I have been indebted, and special acknowledgement of those more recent sources of information not alluded to in any other book on Madagascar. There are many things in this book derived from native sources that have not been utilized before.

Believing that 'a plain tale speeds best being plainly told,' I have tried to tell my story in plain and pointed language, and I hope I have also been able to tell it graphically enough to make it interesting. My great 
difficulty has been condensation; very often paragraphs have had to be reduced to sentences, and chapters to paragraphs.

One who has spent thirty years in the hard, and often very weary, work of a missionary in Central Madagascar-not to mention the arduous and exhausting duties of deputation work while on furlough-with all the duties, difficulties, and anxieties involved in the superintendence of large districts, with their numerous village congregations and schools, could hardly be expected to have much spare time to devote to the cultivation of the graces of literature or an elegant style. I have tried to tell my story in a warm-hearted way, being anxious only that my meaning should be clearly expressed, whatever might be its verbal guise. I have never been able to understand why, without flippancy or irreverence, religious topics may not be treated at times ' with innocent playfulness and lightsome kindly humour.' Why, too, should the humorous side, and even humorous examples, be almost entirely left out of records of foreign mission work? Such incidents sometimes help to relieve the shadows by the glints of sunshine, and for this reason I have ventured to describe the bright, and even humorous, as well as the dark side of missionary work. I have tried to set forth the joy and humour as well as the care, the sunshine as well as the shadow.

John Ruskin says: 'A man should think long before he invites his neighbours to listen to his sayings on any subject whatever.' As I have been thinking on the subject of missions for forty years, and have been engaged in mission work for thirty, if my thoughts are not fairly mature on the subject now, and my mind made up on most points in relation to missions and 
mission work, they are never likely to be. At the same time, when an unknown writer asks the attention of the Christian public upon such an important theme as foreign missions, he is at least expected to show that he has such a thorough and practical acquaintance with them as fairly entitles him to a hearing. I hope the following pages will prove my claim to this consideration. If they help to create interest in the great cause of foreign missions in some quarters, and to deepen it in others, I shall feel well repaid for all the trouble the preparation of them has cost me.

I am deeply indebted to friends for their valuable help and advice, and render them my very hearty and sincere thanks. 



\section{CONTENTS}

Chapter I. PAGE

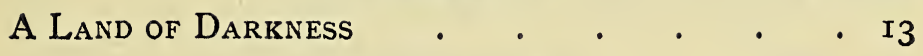

Chapter II.

'The Killing Times' . . . . • 42

Chapter III.

From Darkness to Dawn . . . . . . $\quad$. 69

Chapter IV.

The Morning Breaking . . . . . 87

Chapter V.

Breaking up the Fallow Ground . . . 107

Chapter VI.

EArly Experiences • • . • • • . . I23

Chapter VII.

Shadow and Sunshine $\quad$. $\quad . \quad$. 142

Chapter VIII.

District Journeys And InCidents . • . . . I68

Chapter IX.

Development and Consolidation . . . . $\quad$ r 83

Chapter X.

The Dead Past . . . . . . . . 202 
8

Contents

Chapter XI. PAGE

Progress all along the Line. . 213

Chapter XII.

Gathering Clouds

Chapter XIII.

Bible Revision and 'an Old Disciple' • . 248

Chapter XIV.

The Light Extending

Chapter XV.

The Conguest of Madagascar . . . . . $29 \mathrm{I}$

Chapter XVI.

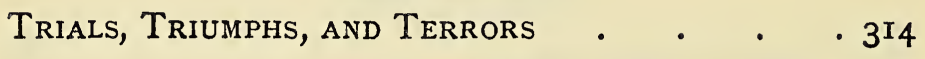

Chapter XVII.

The End of the Monarchy • • . . 352

Chapter XVIII.

The Triumph of the Gospel . . . . . . 369

INDEX $\quad$ - $\quad . \quad \cdot \quad \cdot \quad \cdot \quad \cdot \quad \cdot 38 \mathrm{I}$ 


\section{LIST OF ILLUSTRATIONS}

The Rev. T. T. Matthews . . . Frontispiece

MaP of MadaGascar . . . . To face page I3

Malagasy Hair-dressing . . . . . " 28

A Heathen War-dance . . . . . " " 28

The Cave in which the Bible was hid for

Twenty Years . . . . . . " " 44

The Fosse in which Rasalama was speared " 44

The Martyrdoms at Ampamarinana . . " 5 I

The Spearing at Anbohipotsy . . . " 60

The Stoning at Fiadanana . . . . " , 60

The Burning at Faravohitra . . . " " 60

Criminals in Chains, illustrating how the

MARTYRS WERE TREATED . . . . " " 64

Radama I. Radama II . . . . . " 74

The Royal Idols of Madagascar . . . " 74

The Palace, Antananarivo . . . . " 74

A River Scene and a Forest Scene in Mada-

GASCAR . . . . . . . .

Heathen Malagasy . • . . . . " io 
Malagasy Types: A Hova Princess. A Hova Christian. A Minstrel. Malagasy POUNDING Rice . . . . . . To face page II 2

The Palace Church, Antananarivo . . " im

Malagasy Christian Workers . . . " I44

A Group of Native Preachers and EvanGELISTS . . . . • • . . "

Analakely: Church and Market-Place . ” I64

The Piazza, Andohalo . . . . . " " 164

Martyrs' Memorial Church, Fihaonana . „ 186

The Spurgeon of Madagascar . . . " 186

Martyrs' Memorial Church, Ampamarinana „ 186

The Mission Hospital. Miss Byam, the

Matron. A Group of Nurses . . " 195

Suburban Church, Old Style . . . " $20 \mathrm{I}$

Suburban Church, New Style . . . " $20 \mathrm{I}$

IMERIMANDROSO CHURCH . . . . . " $20 \mathrm{I}$

Memorial Church, Ambatonakanga . . " 230

INTERIOR OF THE CHURCH . . . . " 230

Ambatonakanga from Faravohitra . . " 237

Antananarivo on a Fête Day • . • " 237

The Queen of Madagascar on The Way to THE LAST REVIEW . . . . . " 245

A Garden Party at the Queen's Gardens " 245 


\section{List of Illustrations}

The Author travelling in Palanquin. The

Manse at Finaonana . . . To face page $25^{\circ}$

Fianarantsoa, Capital of Betsileo. . . " $\quad 267$

MALAGASY WORKING THE SOIL . . . . " 267

The Old School, Ambatonakanga . • • „ 279

The New School, Ambatonakanga. • • „ 279

Group of Scholars, Teachers, and Christian

WORKERS • . . . . . . " 279

The Last Kabary . . . . . . ” $29 \mathrm{I}$

The QueEn's Lake, Antananarivo. • . " 29 I

Rainilaiarivony, the Last Prime Minister of MAdAGASCAR . . . . . . " 300

William and Lucy Johnson . . . . ”305

General Gallieni . . . . . . " 320

B. Escande. P. Minault • • • • " 353

The Last Queen of Madagascar . . . „ 359

The London Missionary Society PrintingOFFICE • . . . . . . " 364

The Normal School • • • • • " 364

The Governor of Tamatave . . . . " 374 




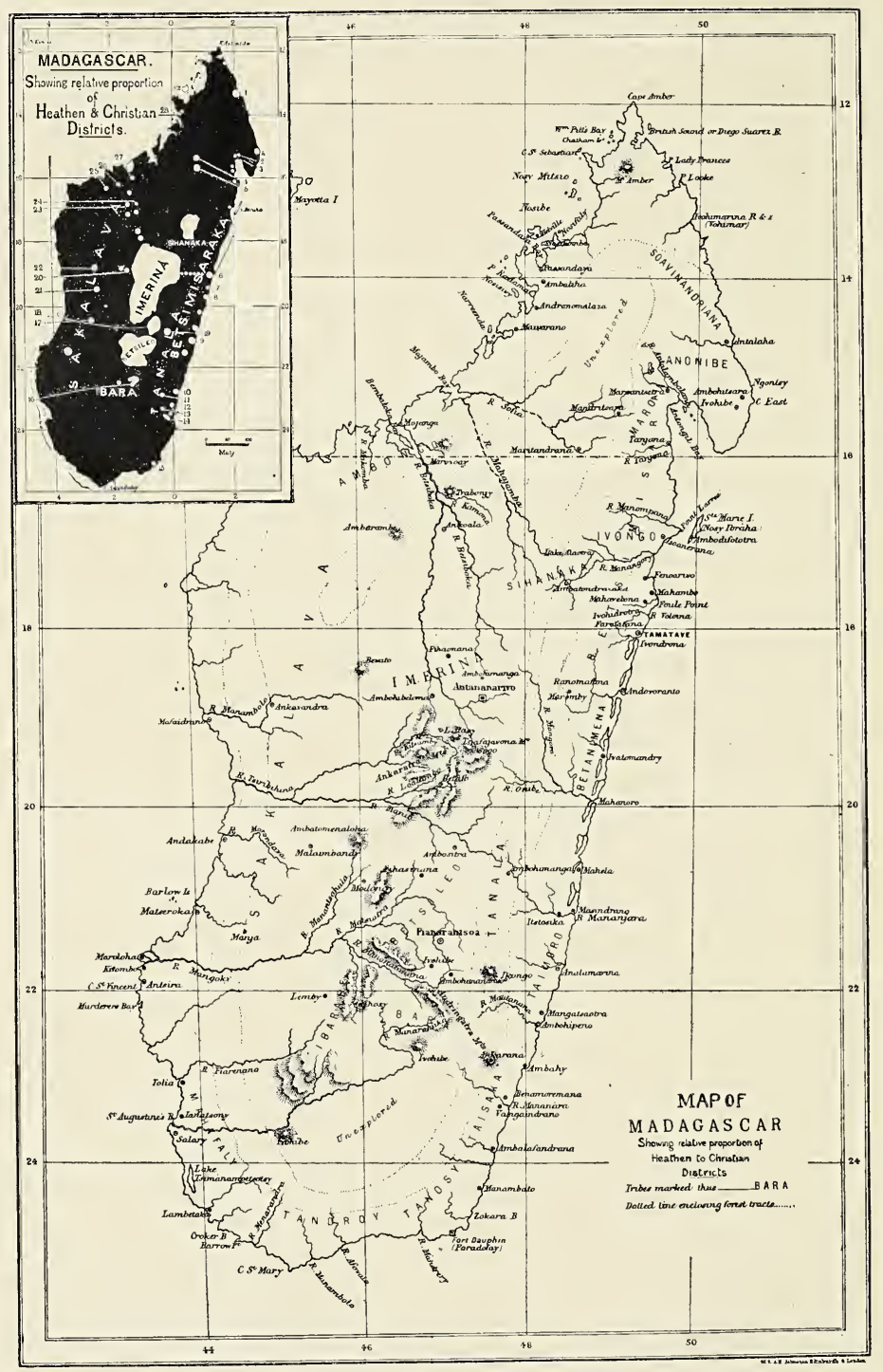

MAP OF MADAGASCAR. 


\section{THIRTY YEARS IN MADAGASCAR}

\section{CHAPTER I}

\section{A LAND OF DARKNESS}

'He brought them out of darkness.'-Psalm cvii. I4.

MADAGASCAR is the third largest island in the world, about I,O0o miles long, by 375 at its widest part, with an average breadth of about $25^{\circ}$ miles. It has an area of about 230,000 square miles, so that it is almost four times the size of England and Wales, or two and a half times that of Great Britain and Ireland, or seven times the size of Scotland!

This important island is situated in the Indian Ocean, and separated from the east coast of Africa by the Mozambique Channel, which is some 250 miles broad. It lies between latitude $12^{\circ} 2^{\prime}$ to $25^{\circ}$ I $8^{\prime}$ south of the line, and longitude $44^{\circ}$ to $50^{\circ}$ east of Greenwich, about $55^{\circ}$ miles to the north-west of the island of Mauritius-the far-famed 'key of the Indian Ocean'-some 950 miles to the north-east of Port Natal, and $75^{\circ}$ to the south-east of Zanzibar.

'Although visited by Europeans only within the last 400 years, Madagascar has been known to the Arabs for many centuries, probably a thousand years at least, and also, although perhaps not for so long a time, to the Indian traders of Cutch and Bombay.' Moreover, some of the great classical writers of Greece and Rome, such as Aristotle, Pliny (the elder), and Ptolemy, seem 
to have heard of Madagascar; though until a few years ago this had escaped notice, owing to the fact that the island was known to them by different names.

There is perhaps some ground for supposing that the Jews may have known of Madagascar, and that the sailors of Solomon, in their voyages in the 'ships of Tarshish,' may have visited that island. 'Ages before the Arabian intercourse with Madagascar, it is highly probable that the bold Phoenician traders' ventured as far to the south, or at least obtained information about this great island.

The fact that the Ophir of Scripture, from which came the famous 'gold,' is now believed by most high authorities to have been on the east coast of Africa, renders it highly probable that these 'ships of Tarshish,' with Solomon's sailors on board, may have visited Madagascar. If so, it is easy to account for the close resemblance between certain Malagasy and Jewish customs, such as the scape-goat and the sprinkling of blood, or rather their practice of soaking a piece of bulrush in the blood of the bullock killed at the annual festival of the Fandroana, i. e. ' the bath,' and placing it above the lintel of the door of the hut for its sanctification and protection from evil influences. The killing of a bullock at the annual festival of the Fàndròna seems to suggest some slight connexion with the Jewish sacrifice of a bullock on the day of Atonement. Quarrels were made up, and binding engagements entered into, over the body of a slain animal. The Jewish forms of marriage, the practice of levirate marriage, the Jewish law as to bankruptcy, under which the bankrupt and his wife and family were sold into slavery for the behoot of his creditors-there is a Malagasy proverb which says: 'Pretentious, like a slave of Hova parentage'- 


\section{Ancestors of the Hovas}

and other usages seem all to point in the direction of Jewish influences.

There are fifteen different tribes in Madagascar, but the Hova tribe-that occupies the central province of Imèrina, Ankòva (the land of the Hova) - was for about a century the dominant one. The Hovas were not the aborigines of Central Madagascar; these were a tribe or people called the Vazimba, who were dislodged by the ancestors of the Hovas, and who have been extinct for ages. In their heathen state the Hovas worshipped at the tombs of the Vazimba, and offered sacrifices to their shades to propitiate them, as they believed they could harm them or do them good. The Hovas might be called the Anglo-Saxons of Madagascar, a race of foreigners who entered the island I,000, perhaps 2,000 , years ago, and who, strange to say, belong to the Malay portion of the human family, and are thus allied to the South Sea Islanders.

How the ancestors of the Hovas came to Madagascar is a mystery, as the nearest point from which it is believed they could have come is the neighbourhood of Singapore, upwards of 3,000 miles away. Hova tradition states that their forefathers landed on the north-east coast of the island, fought their way gradually up into the interior, and finally took possession of the central province of Imèrina. That is probably as near the truth as will ever be discovered.

'About the seventh century, the Arabs of Mecca took possession of the Comoro Islands, lying to the north-west of Madagascar, and extended their commerce all over the coasts of that great island; and it was to a marked extent their language, civilization, and religion which for centuries dominated the north-west of the island. The great Arab geographer Edresi, who lived in A.D. I099, has left 
among his writings a description of Madagascar, which he calls Zaledi. The same author refers to the emigration of Chinese and Malays, who settled in Madagascar at an epoch which unfortunately cannot now be precisely determined, but which at least is not so very remote; these were probably the ancestors of the Hovas.'

Madagascar was first made known to modern Europe by the celebrated Venetian traveller Marco Polo, in the thirteenth century. He, however, had never seen or visited the island, but had heard during his travels in Asia various accounts of it under the name of Magaster, or Madagascar. He devotes a chapter of his most interesting book of travels to a description of the island; but he seems to have confounded it with Magadoxo on the adjoining coast of Africa, as much of what he relates is evidently confused with accounts of the districts on the mainland of Africa, and of the island of Zanzibar, since he says that ivory is one of its chief products, and that it contained elephants, camels, giraffes, panthers, lions, and other animals which never existed in Madagascar. The 'rock' or 'rukh,' a gigantic bird which he describes, is in all probability the aepyornis, the original of the huge bird of Sinbad the Sailor, long deemed fabulous. The aepyornis, now extinct, was a struthious bird allied to the New Zealand moa. It produced an egg which would fill a gentleman's silk hat.

It was not until the beginning of the sixteenth century that any European set foot on Madagascar. Towards the end of the fifteenth century the adventurous Portuguese navigators, Bartholomew Diaz and Vasco da Gama, reached the southernmost point of Africa, and rounded the Cape of Good Hope, thus discovering the sea route to India and the far East. On the Mozambique coast 
da Gama found numbers of Arabs trading with India, and well acquainted with the island of Madagascar. In A. D. I 505, King Manoel of Portugal sent out a fleet to the Indies, under the command of Don Francisco de Almeida, who in the following year sent back to Portugal eight ships laden with spices. On their way they discovered, on February I, A.D. I506, the east coast of Madagascar. Joas Gomez d'Abrew discovered the west coast of the island in the same year, on August ro, St. Laurence's Day, from which circumstance it was called the Island of St. Laurence, a name which it retained for more than a hundred years.

During the early times of French intercourse with Madagascar, in the reign of Henry IV, it was known as the Île Dauphiné; this name was never accepted by other nations. There is, however, every reason for believing that the name Madagascar is not a native name, but one given to the island by foreigners. 'Nòsindàmbo' (the isle of wild hogs) was a name sometimes given to Madagascar; but when the Malagasy themselves spoke of the whole island, they usually called it Izao rehetra izao, or Izao tontolo izao (the universe). The Malagasy, like many other islanders, probably thought that their island home, if not the whole universe, was certainly the most important part of it, and that the Arabs and other foreigners came from some insignificant spots across the sea. Another name used by the Malagasy for their island is Ny anivon'ny riaka (what is in the midst of the floods), a name that might be fairly applied to most islands. This name, it is said, was engraved on the huge solid silver coffin of Radàma I, the King of Madagascar, or rather King of the Hovas. On it he was called Tompon'ny anivon'ny riaka (Lord of what is in the midst of the floods). 
As might be expected, the accounts given of Madagascar by early voyagers and writers are full of glowing and extravagant language as to the fertility and natural wealth of the island. Although these are certainly very great, they have been much exaggerated.

The earliest known English book on Madagascar was written by Walter Hammond, surgeon, and published in 1640 . The same author published another book in 1643, dedicated to the Hon. John Bond, Governor and Captain-General of the island of Madagascar; but who this Hon. John Bond was, or what right he had to that title, no one seems to know. In the latter part of the seventeenth century a book on Madagascar was published by a Richard Boothby, merchant in London. From the preface of his book we learn that two years before its publication there had been a project to found an English colony, or plantation, as it was called in those days, in Madagascar.

Doubtless there were many who mourned over the failure of this project, just as there are many, and the writer among them, who regret that the British flag does not wave over Madagascar to-day. Such a state of matters, they think, would be better for the world at large, and for Madagascar in particular. In their opinion the British flag, like the American, represents justice, mercy, and equal rights to all men of whatever clime or colour. This cannot be said to the same extent for all symbols of dominion. British and American statesmen seem still to have a belief-even although at times it may suffer partial eclipse-that 'Righteousness exalteth a nation; whereas sin is a reproach to any people.' Nations, civilized or uncivilized, cannot permanently be governed by falsehood and chicanery.

Until I8 Io Madagascar seems to have been almost lost 


\section{The Slave Trade}

sight of by European nations. In that year the islands of Mauritius and Bourbon, or Réunion, were captured from the French by the British, under Sir Ralph Abercromby. When the peace of 1814 was arranged, the island of Réunion was restored to France; but the island of Mauritius remained in the possession of Great Britain. Shortly afterwards a proclamation was issued by Sir Robert Farquhar, then Governor of the lately acquired colony of Mauritius, taking possession of the island of Madagascar as one of the dependencies of Mauritius. This proceeding, prompted by the belief that Madagascar was such a dependency, was discovered to be a mistake, and all claim to the island was given up.

The slave trade was at that time in full operation in Madagascar. Malagasy slaves supplied the islands of Mauritius and Bourbon, while shiploads were conveyed to North and South America, and even to the West Indies. Slaves could be bought on the coast of Madagascar in those days at from six to twelve pounds, and sold at from thirty to sixty pounds for a man, and at from forty to eighty pounds for a woman; and hence the trade proved a very tempting one to many. It reflects lasting honour on the British nation that no sooner had Madagascar come, to some extent, under the influence of Great Britain, through her possession of Mauritius, than a series of efforts were put forth to annihilate this vile traffic in human flesh. The attitude of British offcers, consuls, and other officials towards man-stealing has ever been most uncompromising. Not even their bitterest enemies have ever dared to accuse them of selling the protection of their country's flag to Arab slavers. And it was due, in the first instance, to the exertions of Sir Robert Farquhar, the able and humane Governor of 
Mauritius, that the slave trade with Madagascar was abolished.

At the close of the year I816 Sir Robert Farquhar sent Captain Le Sage on a mission to Madagascar, to induce Radàma $I$ to send two of his younger brothers to Mauritius to receive an English education. They were sent, and placed under the care of Mr. Hastie, the governor's private secretary, who afterwards took them back to Madagascar; and ultimately became himself the first British Agent to that island, and one of its best and noblest friends, a friend who has never been forgotten, notwithstanding all that has taken place in recent years. A most favourable impression was made on the mind of Radàma $I$ by the way in which his brothers and he had been treated by Sir Robert Farquhar and the British.

Advantage was taken of this impression, and Mr. Hastie had instructions to negotiate a treaty with Radàma I for the abolition of the slave trade. This he ultimately accomplished by promising an annual subsidy from the British government of some two thousand pounds; and a present of flint-locks and soldiers' old clothes for the king's army. No act of Radàma's life shed such lustre on his reign, or will be remembered with so much gratitude, as his abolition of the slave trade. Sir Robert Farquhar, however, contemplated not merely the civilization of Madagascar, but also its evangelization. With this in view, he wrote to the Directors of the London Missionary Society suggesting Madagascar as a field for missionary enterprise, and giving them every encouragement to enter upon it.

At one of the earliest meetings of the Directors of the Society in 1796 the subject of a mission to Madagascar was taken up; and when the subsequently famous 
Dr. Vanderkemp left England in 1796 for South Africa, he had instructions to do all in his power to further the commencement of missionary operations among the Malagasy. The propriety of his paying a visit to the island to learn all he could for the guidance of the Directors was suggested. In $1_{8}$ I $_{3}$ Dr. Milne, whose name was destined to be so honourably connected with China, was also instructed to procure in Mauritius, on his way to China, all available information regarding the contemplated sphere of labour.

But it was not until 1818 that the first two London Missionary Society missionaries left our shores for Madagascar. In November of that year the Rev. D. Jones with his wife and child landed at Tàmatàve, and in January, I8I9, the Rev. T. Bevan with his wife and child arrived, only to find that Mrs. Jones and her child were already dead of fever, while Mr. Jones lay very dangerously ill with it. Mr. Bevan at this seems to have lost heart. His child died on January 20 , he himself on the 3 Ist, and his wife on February 3. Thus within a few weeks of landing on the coast of Madagascar, five of the mission party of six had passed away, and the sole survivor was at the gates of death! They did not then know, what we know now, the proper season for landing on the coast of Madagascar. They landed just at the beginning of the fever season, and having no quinine they were but imperfectly equipped for fighting so dire a foe as Malagasy fever.

When able to travel, Mr. Jones returned to Mauritius to recruit his strength, and in September, 1820, he returned to Madagascar, along with Mr. Hastie, the first British Agent appointed to the court of Radàma I. The king received them very kindly, and when he understood the object of Mr. Jones's coming, he sent a letter 
to the Directors of the London Missionary Society, in which he said: 'I request you to send me, if convenient, as many missionaries as you may deem proper, together with their families, if they desire it, provided you send skilful artisans, to make my people workmen as well as good Christians.'

Accordingly between 1820 and 1828 the Directors of the London Missionary Society sent fourteen missionaries to Madagascar-six ordained men and eight missionary artisans. Among the latter were a carpenter, a blacksmith, a tanner, a cotton-spinner, and a printer. Thus almost all that the Malagasy know to-day of the arts and industries of civilized life, in addition to the knowledge of 'the way of Salvation,' they owe to the missionaries of the London Missionary Society. The best of the Malagasy people have always been grateful to the Society for all it has done through its agents for their temporal and spiritual welfare.

Recently, however, another and a very different version of Malagasy history has been produced. It begins by casting reflections upon our work in Madagascar. We are told that the British missionaries have never done anything for the Malagasy, except to teach them to sing a few hymns and make hypocrites of them ! We are seriously asked to believe that the Malagasy owe all their knowledge of civilization, and of the various arts and handicrafts of civilization, to a French sailor, who was wrecked on the coast of the island, found his way up to the capital, and there became the very intimate friend (or more, as some French writers maintain) of Rànavàlona $I$, the persecuting queen. Voltaire is credited with saying that he could 'write history a great deal better without facts than with them.' This 'New Version of Malagasy History' fully conforms 


\section{Protestants and the Bible}

to his ideal-the facts are lacking. This 'old man of the sea ' is a myth like his prototype.

Whatever else they may have done, it cannot be denied that the British missionaries were the first to reduce the language to writing. When the missionaries arrived in Madagascar the people had no written language. The king had four Arabic secretaries, and, but for the advent of the missionaries, in all probability the characters used in the language of Madagascar would have been Arabic, which of course would have made the acquisition of the language much more difficult to foreigners than it is. When the king saw the Roman characters, he said: 'Yes, I like these better, they are simpler, we'll have these.' And so the character in which the language of Madagascar was to be written and printed was settled by the despotic word of the king under the influence of the missionaries.

When the language was mastered, and reduced to writing, the first task the missionaries undertook was the translation of the Scriptures. Here lies the radical distinction between Protestant and Roman Catholic missionaries. The former always give the people as soon as possible the Word of God in their own tongue; the latter never give it. There have been Roman Catholic missionaries in various parts of Madagascar since 1641 ; but they have never yet translated the Scriptures into Malagasy, and are not likely to do so. When the missionaries had translated and printed the Gospel of St. Matthew they sent up a copy to the king. It was read to him by one of his young noblemen whom the missionaries had taught to read. The king did not seem particularly interested in the Gospel until the account of the Crucifixion was reached, when he asked: 'Crucifixion, what is that?' It was explained to him. 
'Ah!' he said, 'that's a capital mode of punishment; I will have all my criminals crucified for the future. Call the head-carpenter.' He was called, and ordered to prepare a number of crosses. I was very intimate for fourteen years with a Malagasy native pastor who had seen some of those crosses. During the dark and terrible times of persecution, tyranny, and cruelty under the rule of Rànavàlona I, some criminals, it is said, were really crucified.

When there was an addition to his family, Radàma I used to proclaim an Andro-tsi-màty-a day of general and unrestrained licentiousness. The whole country, and the capital in particular, was turned into a pandemonium of bestiality. Similar licence attended the great gatherings for the ceremony of circumcision. Mr. Hastie, the British Agent, compelled Radàma to put a stop to these orgies. He threatened, if another were proclaimed, to publish the proclamation in every gazette in Europe, and thus expose and hold him and his court and people up to the execration of Christendom. This had the intended effect. The king was always anxious to stand well with the nations of Europe; but when his wife came to the throne, she, being herself a shameless and outrageously licentious woman, restored these hideous customs.

Some years ago a missionary on the Congo stated in Regions Beyond that moral purity was quite unknown where he was labouring. A girl morally pure over ten years of age could not be found. It was the same in Madagascar, and is the same there to-day among the tribes that have not yet been reached by Christianity. Heathenism presents an indescribable state of things, and yet it never was so bad in Madagascar as in some other lands. A missionary from Old Calabar declared 


\section{The Malagasy 'Peter the Great'}

some years ago that in the sphere where he laboured he did not know a woman either in the Church or out of it who, in the days of heathenism, had not murdered from two to ten of her own children. The dark places of the earth are not only the habitations of cruelty, but of every unutterable abomination.

Radàma I was an extraordinary man. He has been called the 'Peter the Great' of Madagascar, and from some points of view perhaps he deserved the title. Some called him the 'Noble Savage'; but he hardly deserved the epithet of 'noble,' for he was ruthless and cruel. At his first interview with $\mathrm{Mr}$. Hastie and Mr. Jones he seems to have been so pleased with them that he invited them back to dine with him next day. They accordingly went to the palace, and while they were seated at table a slave bringing in a tureen stumbled and spilt a little soup on it. Radàma turned and looked at one of the officers who stood behind him, and the latter left the room. When Mr. Hastie and Mr. Jones quitted the presence of the king, they saw the headless body of the poor slave lying in the yard. $\mathrm{He}$ had had his head struck off for insulting the king by spilling soup on the table in the presence of the sovereign and his guests! On another occasion, in I 826, the king went down to the port of Tàmatàve to see a British man-of-war. While at Tàmatàve he sent a slave up to the capital with a message, giving him six days to go up and return. It is still regarded as a hard journey either to go up to the capital or to come down in six days. This poor slave must have run every hour of those nights and days; and yet because he did not return on the evening of the sixth day, but the morning of the seventh, he was killed! Terrible as such things are, they are mild compared 
with some of the enormities perpetrated in heathen countries.

Radàma died in $\mathrm{I} 828$, a victim to his own vices. Rabòdo, his wife, or rather one of his wives, for he had twelve, by the aid of a number of officials, who were most of them opposed to Christianity and to the changes introduced by Radàma $\mathrm{I}$, had herself proclaimed queen as Rànavàlona $I$. She soon made her position secure by murdering all the lawful heirs to the throne. Radàma had designated Rakòtobè, his nephew, the eldest son of his eldest sister, as his successor. He was a young man of intelligence who had been trained by the missionaries in their schools. He and his father and mother were put to death, as were also a number of the more enlightened officials. Andrìmihàja, a young Malagasy nobleman who had been a very great favourite with the queen, and had been mainly instrumental in placing her on the throne, and who was believed to be the father of her child, the future Radàma II, soon fell under her displeasure and was murdered. He had been considerably attracted towards Christianity, and at the time when his executioners reached his house he was reading the recently translated New Testament.

The original plan had been to banish all Europeans at once; but on the ground that they were useful in the work of education and civilization, he had secured their continuance for a time in the island, and had also aided and encouraged the work of the artisan missionaries. The queen sent to the missionaries to say that she did not mean to interfere with them or their work, as she was no less anxious than her late husband that the people should learn to be 'wise and clever.' The missionaries therefore thus continued to labour, and such 


\section{A Malagasy Enthusiast}

great progress was made that they and their converts very soon got into trouble.

Rànavàlona I was an able, unscrupulous woman. Her subjects regarded her with terror. She combined the worst vices of barbarism with the externals of semicivilization. Brutal amusements and shameless licentiousness were conspicuous at her court. Her extravagance was great, yet her subjects condoned this, and even her acts of cruelty, on account of her extraordinary capacity for government. She had her rice picked by her maids of honour, grain by grain, so that no atom of quartz or stone might be found in it. If a single particle of grit reached Her Majesty's tooth, it cost the offending maid of honour her life.

'Among those who had gained a slight knowledge of the doctrines of Christianity before the missionaries were expelled in 1836 was Rainitsiandàvaka, in some respects a remarkable man. He was then a middle-aged man, of extra sanguine temperament. He did not belong to the congregation of Ambàtonakànga. He had never been baptized, but he had conversed with some of the church members and with some of the missionaries. After a time he began to make a stir in and around his own village in the north, teaching the people that Jesus Christ was to return to the earth, when all men would be blessed and perhaps never die; that there would be no more slavery, for all men would then be free; that there would be no more war, and that cannons, guns, and spears would be buried. Even spades might be buried then, for the earth would bring forth its fruits without labour. The idols, he said, were not divinities, but only guardians.

' $\mathrm{He}$ and his followers formed themselves into a procession, and went up to the capital to tell the queen the glorious news. The queen appointed some of her 
officers to hear his story. They returned and reported it to Her Majesty. She sent back to ask him if she, the Queen of Madagascar, and the Mozambique slave would be equal in those days? "Yes," he replied. When this was told the queen she ordered the prophet and his chief followers to be put into empty rice-pits, boiling water to be poured over them, and the pits to be covered up ${ }^{1}$.'

Such is heathenism! Missionaries are sometimes charged with a tendency to give only the bright side of things without much reference to the other. The charge is unjust. Common decency forbids more than a suggestion of what heathenism implies. The missionaries are the 'messengers of the churches,' whose task it is to make the darkness light, and their narratives must necessarily bear upon the results of their labours. By God's good help and blessing, what has been done in Central Madagascar, in the islands of the South Seas, in New Guinea, in Central Africa, in Manchuria, in Livingstonia, and in other parts of the mission field, can be told; while that which the Gospel has supplanted may well be left to be the unspeakable hardship of those who have to face it in the name of their Lord, and of our common Christianity and civilization.

A famous missionary once attempted to tell his experiences as to heathenism, and got himself into trouble for his pains. Missionaries give their hearers credit for Christian common sense, and for the knowledge that there is a dark and dreadful side to missionary work, such as to justify the sacrifices of the churches and their agents in undertaking it. One significant fact may be mentioned here. While there was a name for every beast, and bird, and blade of grass, and tree, and stone, 


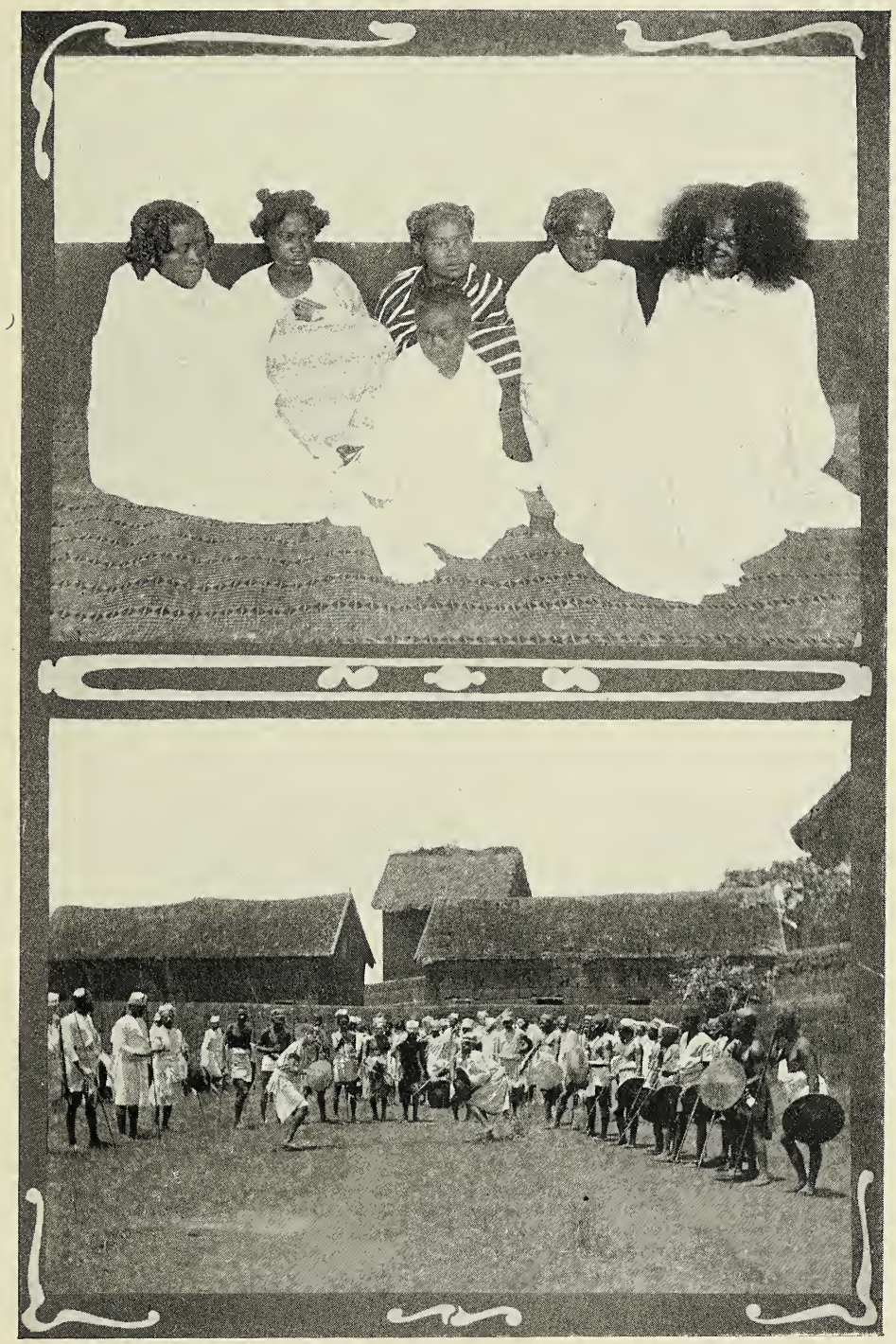

MALAGASY HAIR-DRESSING.

A HEATHEN WAR-DANCE. 



\section{Translation of the Bible}

and creeping thing, there was not in the language of Madagascar a word for moral purity. Such a thing had no existence until the people received the Gospel, and learned from it to value the things that are pure, lovely, and of good report.

In 1823 the work of translating the Scriptures into Malagasy was begun, and in 1824 Radàma I gave the missionaries permission to preach the Gospel in the vernacular. The natives were not a little amazed to hear a European declaring to them with fluency in their own tongue the wonderful works of God. The mission made very rapid progress for a few years. There were about a hundred schools established in the provinces of Imèrina and Vònizòngo, and some four thousand children gathered into them. These schools were not centres where a large amount of secular and a small amount of religious education was given ; they were also preaching stations, visited periodically by the missionaries, where the Gospel was preached and the Scriptures were explained. The truth thus found entrance into many benighted souls, laying hold of them in a way that nothing had ever done before, proving that it was still the power of God unto salvation unto every one that believeth. Many had grown weary of their old heathenism, and were feeling after God, if haply they might find Him.

The people had often spoken of Andriamanitra ${ }^{1}$ Andrianànahàry (God the Creator) as existing, and the people had been told in their proverbs, with which all were familiar, that 'God looks from on high and sees what is hidden'; that they were 'Not to think of the

1 Literally 'The Fragrant One,' suggesting freshness. 'In primitive religious thought, the idea of godhead is specially connected with that of fresh unfading life, and the impurity which must be kept aloof is associated with physical corruption and death.' 
silent valley' (that is, as a place in which it was safe to commit sin); 'for God is over our head.' They were told that 'God loves not evil'; and also that 'It is better to be condemned by man than to be condemned by God '; and again that 'The waywardness of man is controlled by God ; for it is He Who alone commands.'

In their proverbs God was also acknowledged as 'the Giver to every one of life.' This confession is found in the ordinary phrase used in saluting the parents of a newly born child, which was, 'Salutation! God has given you an heir'; while His greatness is declared in another proverb which says, 'Do not say God is fully comprehended by me.' He was recognized as the rewarder both of good and evil ; and hence their proverb, ' God, for Whom the hasty won't wait, shall be waited for by me.' God's omniscience was recognized in the proverb, 'There is nothing unknown to God, but $\mathrm{He}$ intentionally bows down His head' (that is, so as not to see); a rather remarkable parallel to the Apostle Paul's words, 'The times of ignorance, therefore, God overlooked.' One proverb says, 'Let not the simple or foolish one be defrauded, God is to be feared '; while another tells that, "The first death may be endured, but the second death is unbearable.'

In the Malagasy proverbs and folk-lore you have some few of the 'fossilized remains of former beliefs'; and in these the people were told something of God and goodness, of right and wrong, while hints were given of a life beyond the grave, where good men would be rewarded and wicked men punished.

These, however, were but ragged remnants of former beliefs, which, while they might be enough to show that God had not left Himself without witness, had lost most of their meaning for the people, and almost all 


\section{Evils of Superstition}

their power over them. They were in no way guided by the fear of God in their daily life and conduct. God was not in all their thoughts, for He was a name and nothing more to the vast majority of the people.

The Malagasy were under the baneful sway of the most degrading superstitions. Hence polygamy, infanticide, trial by the poison ordeal, and all the attendant horrors of heathenism were everywhere rampant. The people were goaded on to commit the most cruel and heartless crimes against their nearest and dearest by the Mpanandro (the astrologers), or the Mpisikidy (the workers of the oracle), and the Ombiàsy (the diviners or witch-doctors). They and theirs were harmed or made ill, as they thought, by the Mpàmosàvy (the wizards or witches). They thought that all disease arose from bewitchery, and hence medicine was known as Fànafody, i. e. that which removes or takes off the $\dot{O} d y$, the charm or witchery. The far-famed Odi-mahery (powerfulcharm) for which Vònizòngo, my own district during my first term of ten years in Madagascar, was once so famous, was mainly composed of the same ingredients as the witches' broth in Macbeth-the leg of a frog, the tongue of a dog, the leg of a lizard, the head of a toad, and such like. The great poet says that 'One touch of nature makes the whole world kin,' and the same may be said of the touch of superstition.

The people had been sunk for ages in ignorance, and formed a counterpart to the heathen world which the Apostle Paul describes as 'having the understanding darkened, being alienated from the life of God through the ignorance that was in them, because of the hardening of their heart. Being past feeling, they gave themselves over unto lasciviousness, to work all uncleanness with greediness.' This made them mere playthings in the 
hands of the 'astrologers,' 'workers of the oracle,' and 'diviners'; for without their assistance they regarded themselves as completely at the mercy of the much feared $M \not p a m o s a ̀ v y$ (the wizards or witches).

Everything-marriages, business, journeys-could be happy or successful only if undertaken on an auspicious day, and hence the proper authorities had to be paid to find out the lucky days. If a child was born on an unlucky day, or during the unlucky month of Alakàosy, it had to be put to death, otherwise it was believed it would grow up to be a curse to its parents and its country. Of a child born on one of the so-called unlucky days, or during the so-called unlucky month, the diviner would at once say: 'This child must die, or it will grow up to be a curse to the country, Manana vintan-dràtsy izy (it has a bad destiny hanging over it).'

There were different ways of putting these unfortunate innocents to death. If they were born during the unlucky month, they were placed in the evening at the gateway of the village, to be trampled to death by the cattle as they were being driven into the village for the night. If the gods inspired the cattle to step over the infant, its life was generally, though not always, spared. The Malagasy are very fond of their childrenthe parents would kneel by the pathway, the father on the one side, the mother on the other, pleading, with strong crying and tears, that the gods would spare their little one. Sometimes the cattle, with more sense than the people, when they came up to the babe, would sniff at it and step over it, and thus its life might be spared. This was the case, it is said, with Rainilàiàrivòny, the late prime minister of Madagascar, who was born during the unlucky month. It was not so often that male children were exposed in this way, some excuse 


\section{Heathen Atrocities}

was usually found by the 'diviners'; but as a rule the female children were thus exposed. Twins, whether male or female, were always put to death.

A child was not always spared even when the cattle had stepped over it. The diviner would sometimes say: 'A mistake has been made; this child is not to die in that way, but by the Ahohoka.' Water was poured into a large wooden platter, called a sahàfa. The child was taken, turned over, and its face held in the water until the poor innocent was suffocated. Some diviners were more exacting than others. Instead of effecting death by suffocation, they would cause a round hole to be dug in the ground, in which the child was placed, and covered with earth up to the waist; boiling water was then poured over it until death relieved the poor child of its torments, after which the pit was filled up with earth and pounded over. Thus thousands upon thousands of children fell victims to this superstition, and do so still in those parts of the island unreached by the benign influence of the Gospel of Christ. Members of my own congregation at Fìhàonana, Vònizòngo, had seen such atrocities as those I have just described committed, if they had not themselves. actually taken part in them.

The standard of morality was by no means high in heathen Madagascar. A man might be a drunkard, dishonest, a liar, or quarrelsome and given to fighting, and as such be regarded by his neighbours as a bad man, that is a bad member of society; but in other respects he might be utterly immoral without earning that title. A man's morals were not regarded as having anything whatever to do with his personal character they were regarded as his own private affair. The community passed no judgement upon him. 
I have said a man, because a woman was not really regarded as having any place in society. Women were viewed as little more than chattels necessary for the furnishing of a man's house. They were the slaves of their lord and master. They were spoken of as àmbin-jàvatra, that is, surplus belongings. Under these circumstances the marriage relationship was not regarded as of much consequence, and before 1879 a man had only to say to his wife, in the presence of a witness, Misàotra anào, màndehàna hianào, 'Thanks, go!' and she was divorced. Marriage was said not to be a binding tie, but only a knot out of which you could slip at any time. With such views of the highest and holiest relationship in life, with divorce easy, and polygamy rampant, the condition of society may be better imagined than described. Yet it could not exactly be said of the Malagasy that the 'emblems of vice' had been ever 'objects of worship,' or that 'acts of vice' had ever been regarded by them as 'acts of public worship,' as can be said of the people of some heathen lands.

Such a state of things, of which many were wearied, paved the way, in a measure, for the new teaching. The work of the mission made rapid progress. The Gospel effected a marvellous change in the lives of the people, and numbers were baptized on profession of faith and received into church fellowship. The old heathen party became alarmed at this, and rose in arms against the New Religion. As Samuel Rutherford said: 'Good being done, the devil began to roar.' This he did with a vengeance, making use of all who had vested interests in immorality and superstition, and especially of the keepers of the royal idols. The converts were charged with refusing to worship the gods 
of their forefathers, and to pray to the spirits of their departed ancestors, and with praying instead to 'the white man's ancestor, Jesus Christ.'

History was repeating itself. The keepers of the royal idols frightened the queen by telling her that the gods were getting exasperated, and that if they once were enraged they would send fever, and famine, and pestilence, and all kinds of calamities. Although a strong-minded woman, and in some respects unusually shrewd, the queen was very superstitious, and the idol-keepers and the heathen party were able to work upon her fears, and, as the issue proved, with deadly effect.

'She determined to introduce important changes in the government of the kingdom. She gave notice to the British Agent, and all Europeans, of her withdrawal from the treaty which Radàma I had made with the British government for the abolition of the foreign slave trade. She picked a quarrel with the British Agent because he had ridden on horseback into the village where a celebrated idol was kept, drove him from the capital, and ultimately from the island ${ }^{\text {?.' }}$ Things had seemingly reached a crisis, and the missionaries felt that they might soon have to follow the British Agent; but this was for a time prevented by a rather singular incident.

There was no soap of any kind in Madagascar in those days. The queen had come into possession of some English soap, and thought it desirable to get the white teachers to make soap from the materials found in her own island, and instruct some of her young noblemen to make it. This is not exactly noble-

1 Cameron.

C 2 
men's work, as we should think ; but in those days, and in that land, every one had to do as the queen commanded, or have their heads cut off. To attain her object she resolved to keep the gods and the royal idol-keepers quiet for a time, until some of her young noblemen had learned the mystery of soapmaking.

She had already proposed to the missionaries that they should confine their efforts to mere secular education, which, however, they had politely but firmly declined to do. The influence of the artisan missionaries had been of immense service to the Madagascar Mission in those early days of its existence ; and mainly to their teaching must be attributed much of the skill of the Malagasy workmen to this day. There can be no doubt that the manifest utility of their work did much to win for the mission a large measure of tolerance, as this incident of the soap-making shows.

'Having driven the British Agent from the capital and the island, and wishing next to get rid of the missionaries, the queen sent and asked them all to meet at the house of the senior missionary, as she had a communication to make to them. The queen's messengers met them, and in her name thanked them for all they had done and all they had taught the people. The queen wished to know, they said, if there was anything they could still teach her people. The missionaries replied that they had only taught the very simplest elements of knowledge, and that there was still many things of which the Malagasy were quite ignorant, and they mentioned sundry branches of education, among which were the Greek and Hebrew languages, which had been partially taught to some. The messengers carried this answer to the queen, and when they came 


\section{Theologians and Soap}

back they said that the queen did not care for the teaching of languages that nobody spoke; but she would like to know, they said, whether they could not teach her people something more useful, such as the making of soap from materials to be found in the country ${ }^{1}$.'

This was rather an awkward question to address to theologians, and the ministerial members of the mission were much perplexed. Instruction in soap-making had not been part of their college training, and they knew little about it. 'After a short pause, the senior member of the mission asked Mr. J. Cameron whether he could give an answer to that question. Mr. Cameron replied: "Come back in a week, and we may give an answer to Her Majesty's inquiry." At the end of the week they returned, and Mr. Cameron presented them with two small bars of tolerably good soap made entirely from materials found in the island ${ }^{1}$.' This incident, along with the conversations which the missionaries had with Her Majesty's messengers, arrested for a time the backward trend of things. It revealed to Her Majesty and her heathen advisers their want of knowledge about the most common things, and their need of the most elementary education, and led to further inquiries about various matters. The tone adopted towards the missionaries and the treatment of them and their converts became more gentle and considerate.

The queen herself was so pleased with the soap that, on condition that Mr. Cameron would undertake a contract to supply the palace and the government with a certain amount of soap, and teach some of the young noblemen how to make it, things were to be allowed

1 Cameron. 
to go on ; and the missionaries were not to be interfered with in their work. Mr. Cameron and Mr. Chick, another of the artisan missionaries, undertook contracts for soap-making and the production of other useful articles. The government wanted them to undertake a contract for making gunpowder; but this they declined. It took nearly five years to fulfil this agreement. Perhaps their brethren had given Messrs. Cameron ${ }^{1}$ and Chick a hint to deal out their instruction as to the soapmaking in homoeopathic doses, so that they might be able to accomplish as much as possible of their higher service to Madagascar before the end of the period at which the contracts expired. One most important result to the mission from these contracts was a fresh impulse to the work of education throughout the central province. New schools were allowed to be established, and, although the queen and government would have much preferred to patronize merely secular education, had the missionaries agreed to separate it from religious. teaching, they were constrained for the sake of the secular instruction to sanction and countenance the religious education.

$1 \mathrm{Mr}$. Cameron was a lineal descendant of the massacred chief of Glencoe. It was known that the three sons of the chief escaped on the night of that terrible massacre ; but they were lost sight of, and historians could not tell what afterwards became of them. One of them fled over the hills into Morayshire, changing his name, and two of his descendants are to be found in a northern city to-day. The other two, escaped into Perthshire, took their mother's name of Cameron-she was a Cameron of Lochiel. One of them, Hugh, afterwards emigrated to Canada, the other lived and died in Perthshire. His eldest son became the tax-collector of the village of Dunkeld, and his eldest son James went to Madagascar in 1826 as a missionary artisan (he had been instructed and greatly helped in his studies by the late Rev. Mr. Black, Congregational minister of Dunkeld). 
The education of the young naturally formed an important element in the work of the mission from its commencement, and under the patronage of Radàma I the work flourished greatly. Radàma never became a Christian. 'My Bible,' he would say, ' is within my own bosom.' But he was a shrewd and clever man, and his ideas had been much broadened through intercourse with foreigners, and especially through his constant intercourse with Mr. Hastie, the British Agent, and he clearly saw that the education of the children would be an immense gain to his country. Thus he did all in his power to further this branch of missionary work, and both he and $\mathrm{Mr}$. Hastie showed great interest in the prosperity of the schools.

In the year 1826 about thirty schools had been founded, and there were nearly 2,000 scholars; in 1828 the schools were forty-seven, but the number of scholars had fallen to $r, 400$. At one time the missionaries reported 4,000 as the number of scholars enrolled, though there were never so many as this actually receiving instruction. During the fifteen years the mission was allowed to exist $(1820-1835)$ it was estimated that from 10,000 to 15,000 children passed through the schools; so that when the missionaries were compelled to leave the island there were thousands who had learned to read, and who had by the education they had received been raised far above the mass of their heathen fellow countrymen.

The direct spiritual results of the missionaries' work were of slow growth, and it was not till eleven years after Mr. Jones's arrival in the capital that the first baptisms took place. This was on the Sabbath, May 29, I 83r, in Mr. Griffiths's chapel at Ambòdin-Andohàlo, when twenty of the first converts were baptized in 
the presence of a large congregation. On the next Sabbath, June 5, eight more were baptized by Mr. David Johns in the newly erected chapel at Ambàtonakànga.

From this time the growth was comparatively rapid and encouraging, and by the time of the outbreak of persecution two hundred had been received into church membership.

During the carrying out of the contracts the missionaries were hard at work on their translation of the Scriptures. They knew very well that what had taken place was but a calm before the storm, which they saw approaching, and that when it burst they would all be expelled from the island. They were most anxious to be able to leave the completed translation of the Word of God with the people. In March, 1830, a first edition of 3,000 copies of the New Testament was completed. Messrs. Cameron and Chick used to go down for a few hours in the morning to the Government Works at Ampàribè, to see to the soap-making and other work going on there; and after that they and the other artisan members of the mission went up in turns to help at the printing-office. The ministerial brethren would be there with their translation, and, under the guidance of the superintendent of the press, one member of the mission put up the type, while another brought the paper, another inked the type, and the rest took their turn at working the press. When, as was latterly the case, no labourers could be got to do it, even the ladies of the mission sometimes helped at this heavy task.

Thus these devoted men and women often worked to the small hours of the morning printing off the Scriptures. Before their task was finally accomplished the 


\section{Leaves from the Tree of Life}

New Testament, and also single books of both the Old and New Testaments, were bound up and set in circulation. Single sheets even of the Gospels, tracts, leaves of the Pilgrim's Progress, and of the small hymn-book found their way all over the island; and some of these, as late as $187 \mathrm{I}, \mathrm{I}$ found in the possession of the people in Vònizòngo. 


\section{CHAPTER II}

\section{'THE KILLING TIMES'}

'Yea, and all that will live godly in Christ Jesus shall suffer persecution.' -2 TIM. iii. 12 .

THE edict of Queen Rànavàlona I against the Christian religion was published on March $\mathrm{I}, \mathrm{I} 835$. To effect a return to absolute heathenism at all costs was the settled policy of the queen and her advisers. Christianity and heathen barbarism could not exist together. Very soon, however, to the astonishment of the queen and her advisers, it was found that although the missionaries had been expelled, and the Bible and other religious books burned, a stop had not really been put to the 'praying.' They had not been able to expel the Spirit of God from the hearts of the people. The good seed of the Kingdom began through persecution to strike its roots deeper, and under the influence of the dews of Heaven to spring up and yield fruit. Midnight prayer-meetings were begun in the capital itself, within gun-shot of the palace. At one of those midnight prayer-meetings, when discovery meant certain death, a young man, Razàka, and his wife from Vònizòngo were baptized. $\mathrm{He}$ had been a scholar in the mission school at Fihàonana, and afterwards became the native pastor of the mother-church at Fihàonana, which office he held for more than twenty years. Not only so; he became the Apostle 
of Vònizòngo, and founded some forty of the village congregations in that district.

The queen, thus thwarted, became more incensed than ever, and severer measures were resorted to in order to exterminate the hateful ' praying.' Death was the penalty of the slightest act of disobedience; but still the people continued to pray, and the Kingdom of God to make quiet but sure progress. The queen discovered, as other persecutors had done before, that the more she persecuted the people of God the more they increased and grew. Had the queen taken Christianity under her patronage, after the expulsion of the missionaries, she might have stifled it, or made it a mere name; but in persecuting the Christian faith she did it the best service possible. Persecution rooted and grounded Christianity in the hearts of the Hova people in a way that nothing else could have done. And not only so, but her cruelties did service to the cause of Christ in other lands besides Madagascar; for it was by the light of those martyr fires, which she in her cruelty had kindled, that thousands in this and other lands saw Madagascar, and were roused to take interest in the island and in Christian missions. Thus once more did God make the wrath of man to praise Him.

'At the time when the missionaries left the capital severe persecution was directed against Rafàravàvy, a woman of rank who had become a convert prior to the proscription of Christianity. Her family, and she among them, had once been devoted in an exceptional degree to the service of the national idols. She was accused of "praying," but upon the day they left Antanànarivo she was pardoned on payment of a fine, and warned that if she was again found guilty her life would be forfeited. About a year later, with ten others 
she was again accused of praying and allowing others to pray in her house. When arrested she refused to betray those who had been associated with her. The officers entrapped a young woman named Ràsalàma, who had been included in the same impeachment, into revealing the names of seven Christians hitherto unknown to the officials. Among these was a former diviner, Ràinitsihèva by name, memorable in Madagascar annals by his name of Paul. Rafàravàvy would have been executed, and thus have become the first Christian martyr in Madagascar, but for a great fire on the eve of the day fixed for her execution. This led to a postponement of her execution. Ràsalàma, while in prison, grieved by the weakness which had led her to betray others, uttered words which, on being reported to the commander-in-chief, determined him to put her to death.

'She was ordered for execution next morning, and the previous afternoon was put in irons, which, being fastened to the feet, hands, and neck, confined the whole body in a position of excruciating pain. In the early morning she sang hymns, as she was borne along to the place of execution, expressing her joy in the knowledge of the Gospel, and on passing the chapel in which she had been baptized, she exclaimed: "There I heard the words of the Saviour." After being borne more than a mile farther, she reached the fatal spot-a broad, dry, shallow fosse or ditch, strewn with the bones of previous criminals, outside what was formerly a fortification, at the southern extremity of the hill on which the city stands. Here, permission being granted her to pray, Ràsalàma calmly knelt on the earth, committed her spirit into the hands of her Redeemer, and fell with the executioner's spears buried in her body. 


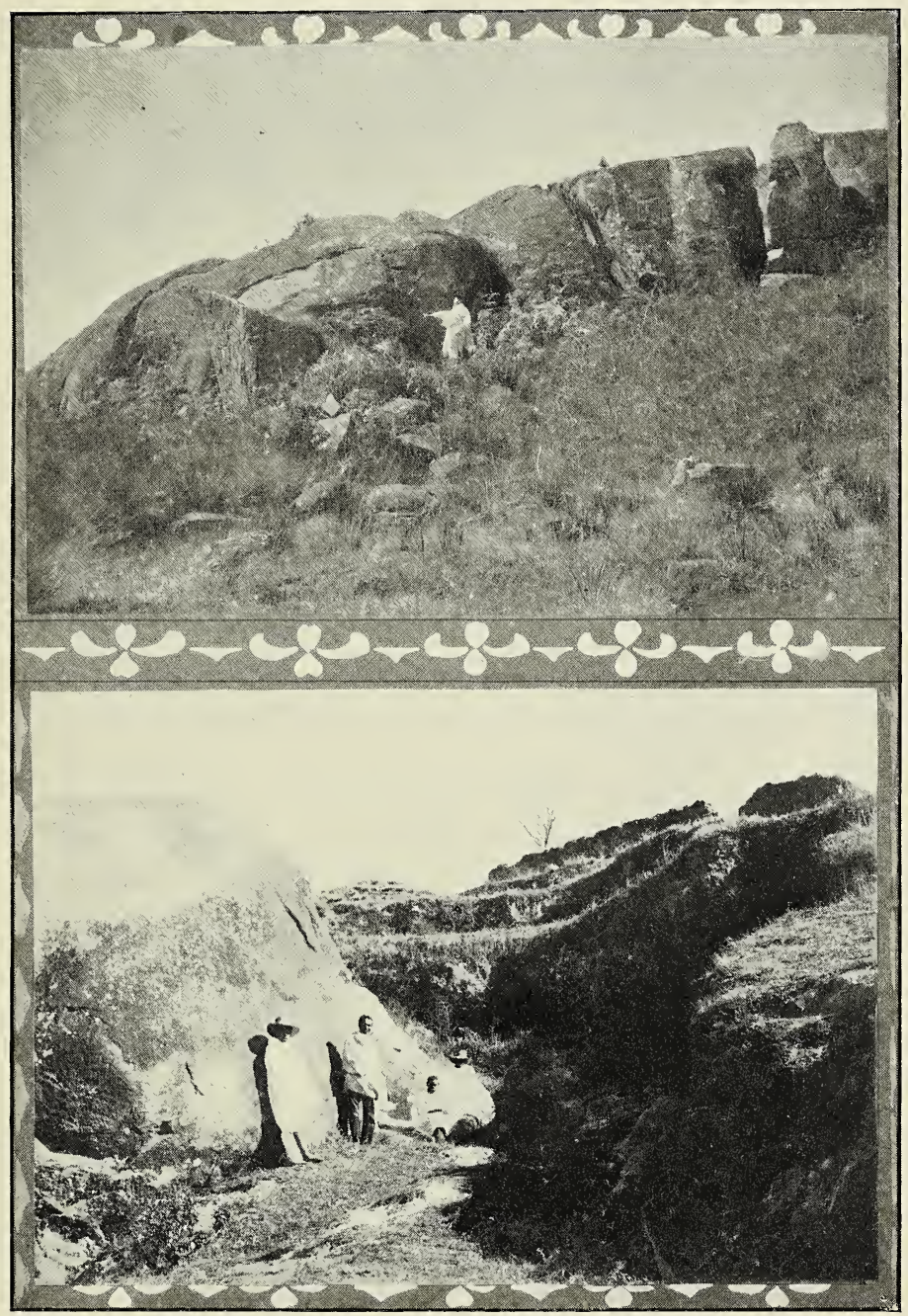

THE CAVE IN WHICH THE BIBLE WAS HID FOR TWENTY YEARS. THE FOSSE IN WHICH RASALAMA WAS SPEARED. 

'So suffered, on August 14, r 837 , Ràsalàma, the first who died for Christ of the martyr Church of Madagascar, which thus, in its early infancy, received its baptism of blood. Heathenism and hell had done their worst. Some few of the bystanders, it was reported, cried out: "Where is the God she prayed to, that $\mathrm{He}$ does not save her now?" Others were moved to pity for one whom they deemed an innocent sufferer; and even the heathen executioners declared: "There is some charm in the religion of the white people, which takes away the fear of death." Most of her more intimate companions were either in prison or in concealment; but one faithful and loving friend, who witnessed her calm and peaceful death, when he returned, exclaimed: "If I might die as tranquil and happy a death, I would willingly die for the Saviour too ${ }^{1}$."

'Ràsalàma was accused of praying, one of her own servants being the accuser. She was taken to the house of one of the high officers in Andòhàlo. This officer made use of bad language towards her, when Ràsalàma severely reproved him, saying: "Take care what you say, for we shall meet again face to face at the last day." The officer replied: "I shall not meet you again, you silly young woman." "You cannot avoid doing so," said Ràsalàma, "for we must all appear at the judgement seat of God on the last day; and every idle word spoken by men shall be revealed to them on the day of judgement."

'Just before her martyrdom, Ràsalàma wrote a letter to one of the missionaries who had taught her, in which she said : "This is what I beg most earnestly from Godthat I may have strength to follow the words of Jesus

${ }^{1}$ Lovett, History of the London Missionary Society, vol. i, pp. 703, 704 . 
which say: "If any one would come after $\mathrm{Me}$, let him deny himself, and take up his cross, and follow Me.' Therefore I do not count my life as a thing worth mentioning, that I may finish my course, that is, the service which I have received from my Lord Jesus. . . . Don't you missionaries think that your hard work here in Madagascar for the Lord has been, or will be, of no avail. No! that is not, and cannot be the case; for through the blessing of God your work must be successful."

"She also called to mind the words of Scripture which say: "Precious in the sight of the Lord is the death of His saints ${ }^{1}$." '

'After the death of Ràsalàma, 200 Christians were sold into slavery. Rafàravàvy was also sold, but her owner, so long as she did her allotted task, allowed her much personal liberty. Among those who had witnessed Ràsalàma's martyrdom was the young man referred to above, named Rafàralàhy, who had been in the habit of receiving Christians for worship at his house near the capital. This man was betrayed by a former friend, an apostate who owed him money, and took this means of cancelling his debt.

'After being confined in heavy irons for three days, he was taken out for execution. On the way he spoke to the officers of the love and mercy of Christ, and of his own happiness in the prospect of so soon seeing that divine Redeemer Who had loved him and died to save him. Having reached the place of execution, the same spot on which Ràsalàma had suffered nearly a twelvemonth before, he spent his last moments in supplication for his country and his persecuted brethren, and in commending his soul to his Saviour. As he rose from

1 Native Narrative of the Persecutions (unpublished). 


\section{Shade and Sunshine}

his knees, the executioners were preparing, as was the custom, to throw him on the ground, when he said that was needless, he was prepared to die; and, quietly laying himself down, he was instantly put to death, his friends being afterwards allowed to inter his body in the ancestral tomb.

'Rafàralàhy's wife was seized, cruelly beaten, and compelled to name those who had frequented his house. Rafàravàvy, one of these, fled, and by the aid of native friends finally reached Tàmatàve. There, by the aid of sympathetic friends among the Europeans, with six other Christians, she escaped to Mauritius in safety. Five of these, including Rafàravàvy, visited England, and were present at a great meeting at Exeter Hall on June 4, I839. Their presence centred extraordinary interest upon Madagascar, and indirectly upon the general work of the Society. The refugees were accompanied by Mr. Johns. They returned to Mauritius in 1842 , and undertook work there among the many Malagasy slaves then in that island ${ }^{1}$ '

The measures taken to destroy Christianity were not at all times equally severe; there were lulls in the storm, during which the persecuted had comparative quietness, and even gleams of sunshine. The years that stand out with special prominence in the annals of the persecution are $1835-37,1840,1849$, and 1857 . The next series of martyrdoms occurred in 1840 . David Griffiths had been allowed to return to Antanànarìvo as a trader, and he, in connexion with Dr. Powell, whom business took to Madagascar, did all in their power to aid those whose Christian faith brought their lives into jeopardy. In May, I840, sixteen of the proscribed made an attempt

${ }^{1}$ Lovett, History of the London Missionary Society, vol. i, pp. 704, 705 . 
to reach the coast. Unhappily, they were betrayed, captured, and, five weeks after their flight, they were brought back. Two managed to escape. Of the rest, on July 9, r840, nine were executed.

Many of the native converts fled to the forests, where they died of fever; or to the mountains, where they lived among the dens and the caves of the earth; or to distant parts of the island, such as to the Ankàrana in the north, or to the Bètsilèo country in the south, or to the Sàkalàva tribe who occupy some six hundred miles of the west side of the island-where the most of them were murdered as Hova spies.

The province of Vònizòngo, being about forty miles to the north-west of the capital, having no governor, and very few government officials, became a hiding-place for many of the persecuted Christians. Midnight prayermeetings were held there for years-first in the house of Ràmitràha, who was afterwards burned at Fàravòhitra, and afterwards in the house of Razàka. The converts travelled twenty, thirty, and even forty miles to attend those meetings. At Fihàonana they had one of the few Bibles that had been saved. This was a well in the desert, for the 'Word of God was precious in those days.' The converts met and spent the night in reading the Scriptures and prayer; and on the very dark nights of the rainy season they ventured on singing a hymn to refresh their weary hearts and souls, trusting the noise of the falling rain would drown their voices, as it might well do. On such nights the queen's spies did not venture abroad.

Many of the persecuted fled from the capital and other parts to Vònizòngo, and hid there for months, and some for years. The rice-pits under the floors of the huts were favourite hiding-places, while refuge was also found 


\section{A Narrow Escape}

among the rocks, in ravines on the hill-sides, and in the 'cave,' used as a small-pox hospital. Some of the ricepits had underground passages connecting them with pits in the neighbouring huts, from which a passage led to the outside, so that if any in hiding in the first rice-pit were searched for, they could crawl into the pit in the adjoining hut, and thence find their way outside.

On one occasion Rafàravàvy Marìa, who afterwards escaped from the island and was brought to England, was in hiding in a hut in Vònizòngo, when an officer sent to search for her arrived in the village. He had come so suddenly that she had not had time to get into the rice-pit or outside into the fosse; she had barely time to crawl under a low wooden bedstead, and the woman of the house had only time to draw the mat on the bed down in front of it to hide her. She put some baskets with rice and manioc on the bedstead, to keep the mat from slipping down, when the officer entered the hut. $\mathrm{He}$ said: 'Have you Rafàravàvy here?' The woman of the house answered : 'Look and see.' He just looked round the hut, did not look under the bedstead, and went away. When he left the village to seek for her elsewhere Rafàravàvy escaped to a place of safety.

When very strict search was made by the queen's orders for Bibles and other Christian books-for she more than suspected that they had not all been given up-the Christians in Vònizòngo were very much afraid they might lose their copy of the Scriptures. They said: 'If we lose our Bible what shall we do?' A consultation was held as to how and where the Bible was to be hidden to ensure its safety; and it was agreed that the best and safest place in which to hide the Bible was the small-pox hospital. The officers dreaded small-pox too much to venture there. 
A little to the north-east of the village of Fihàonana a hill rises, and near the foot of it stands a cluster of large boulders. Inside that cluster, during the lulls in the persecution, from ten to thirty of the converts used to hold a Sabbath morning service. Underneath one of the largest of the boulders, at the foot of the hill, there is an artificial cave, dug out by the people to serve as a small-pox hospital for the village : in the dark corner of this cave the Bible was hidden between two slabs of granite. The queen's officers arrived at the village, as it was expected they would, to search for the Bible and other Christian books, which the queen and government had reason to believe, from the reports of spies, were to be found there. A bootless search was made in the huts of the suspected, in the rice-pits, and in the village fosse; and then the officers directed their way to the cluster of boulders on the hill-side. As they were about to enter the cave where the Bible lay, some one said : ' I suppose you know that this is the small-pox hospital ?' 'We did not,' they said, starting back in horror. 'Wretch! why did you not tell us sooner? Why did you let us come so near ?' The officers beat a hasty retreat, and the Bible was safe. This particular copy is now, and for many years has been, in the library of the British and Foreign Bible Society, Queen Victoria Street, London.

Razàka lay for over two years in hiding in that cave, and during that time he seemed to have learnt most of the Bible by heart. After the martyrdom of Ràmitràha the queen had sent to have him arrested as the ringleader of the 'prayers' in Vònizòngo. Had he been caught, he would have been put to death. He had before that been sold into slavery for his religion; but, as a distant relative bought him, his slavery was of a mild type. He heard that the officers had been 



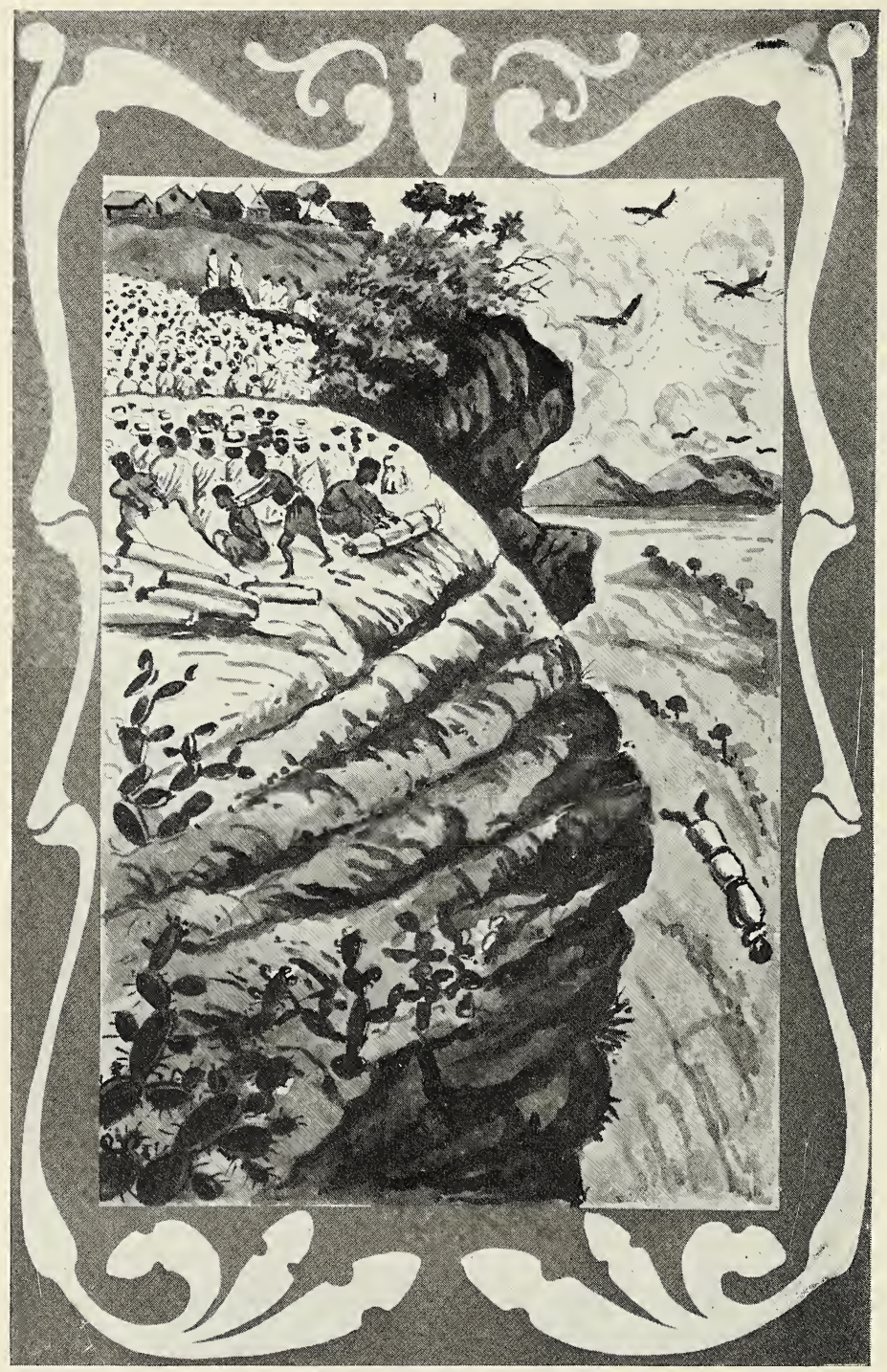

THE MARTYRDOMS AT AMPAMARINANA.

(From a Native Sketch.) 
sent out to arrest him, and went into hiding. A report was spread that he had escaped to the Sàkalàva tribe in the west, and the search was given up.

On a dark night he returned to the cave, and there began his long concealment of two years. At night his wife took him rice; in the daytime, when it was safe, he lay at the mouth of the cave and read and re-read the Bible. How many times he read it through I do not know, but I do know that he had the most extraordinary knowledge of the Scriptures of any man I have met. This qualified him for the honour afterwards conferred upon him of becoming native pastor of the motherchurch at Fihàonana and the Apostle of the Vònizòngo district.

I have been unable to discover the number of church members in the Vònizòngo district when the persecution began, in 1835 ; but in a letter written in 1856 it was stated that there were then 193. I was told, however, in $187 \mathrm{I}$, by Razàka, that when the persecution began, there were thirty-six church members at Fihàonana, ten of whom were then alive. Of the twenty-six dead, two died as martyrs. One, Ràmitràha, was burned at Fàravòhitra Antanànarìvo; the other, Rakòtonomè, was thrown over the rocks at Ampàmarìnana. These men were preachers at Fihàonana.

Ràmitràha was chief of the village and district of Fihàonana-his younger brother was chief in our time; their mother had been the first convert to Christianity in the Vònizòngo district. Ràmitràha seems to have been a very remarkable man. After the outbreak of the persecution, and when it became known that there were many Christians in the Vònizòngo district, several officers and men were sent to bring them to the capital. While the officers were on their way there, Ràmitràha was

D 2 
informed of their coming, and that he was specially named as being a leader, and because midnight prayermeetings had been held in his house. He was advised to flee; but he nobly refused. 'Where could I flee to?' he said. 'If I flee to the west, I shall be speared by the Sàkalàvas as a Hova spy. If I flee to the forest, I shall die of fever. If I flee to the mountains or to the wilderness, I shall die of famine or fever; and if I am to die, I prefer to die for my faith.' He was carried to the capital, along with some three hundred others, of whom the majority did not stand the test. To save their lives they took the oath to worship the idols and pray to the spirits of their ancestors and the departed sovereigns. Ràmitràha stood firm, and died for his faith in the flames. at Fàravòhitra, while his fellow labourer, Rakòtonomè, was rolled down the precipice at Ampàmarìnana.

' All through this period (from 1835 to 1849 ) accused Christians were often compelled to drink the tangèna, and many of them died. But it was not until 1849 that another fierce wave of persecution rolled over the infant church. On February 19, 1849, two houses belonging to Prince Ramònja, which had been used for Christian worship, were destroyed, and eleven Christians cast into prison. A kabàry was held at Andohàlo (the central piàzza of Antanànarivo), and once again Christians were ordered to accuse themselves. In Vònizòngo a noble named Ràmitràha and others refused to worship the idols, and eighteen were condemned to death at Anàlakèly ${ }^{1}$.'

'Ràmitràha, a noble and a descendant of one of the most distinguished chiefs of the province of Vònizòngo, replied-when asked to take the oath invoking the idols-" God has given none to be worshipped on the

1 Lovett, History of the London Missionary Society, vol. i, p. 708. 


\section{A Good Confession}

earth, nor under the heavens, except Jesus Christ." "Fellow," exclaimed the officer, "will you not pray to the spirits of the departed sovereigns, and worship the sacred idols that raised them up?" To which the steadfast confessor replied: "I cannot worship any of them; for they were sovereigns given to be served, but not to be worshipped. God alone is to be worshipped for ever and ever, and to Him alone I pray." This faithful man sealed his testimony to Jesus Christ in the flames.

'On February 25, 1849, the accused Christians were gathered at Andohàlo for examination and trial. They were asked: "What is the reason that you will not forsake this new religion, and that, notwithstanding threats of severe punishment and even death, you keep on earnestly practising it? Speak out and tell the truth, don't lie." They answered, one by one, but the substance of what was said was: "This is the reason why we love it: we can pray to the true God for the queen, the kingdom, and for ourselves who work; and thank Him for redemption and the blessings received at His hands. We know that true religion benefits the kingdom, because in the Word of God, which we accept, there are good laws which benefit the subjects and bless them; and these laws are not opposed to the laws of the land."

'During the first week of March, the Christians throughout the central provinces were ordered to accuse themselves at the appointed place in each district. "I give these 'prayers' time to accuse themselves," said the queen's message; "but not for their own sakes do I give them time, but for the sake of Imèrina; and were it not so, I would put them all to death ; for they persist in doing what I hate ${ }^{1 . "}$ '

${ }^{1}$ Native Narrative of the Persecutions (unpublished). 
'On March 21 and 22, 1849, the Christians were gathered at Anàlakèly, and were again subjected, not to examination as to their rigid adherence to the new religion, but whether they would take the prescribed oath or not. One by one they were asked the following questions, and all gave similar answers.

"The Officer: "Do you still practise prayer?"

"Christian: "Yes, I still pray."

"Officer: "Will you not pray to the twelve sacred mountains, and the sacred idol that raised up and sanctified the twelve sovereigns?"

"Christian: "The mountains are but earth to be trodden upon, and the idols are but wood from which houses are built, quite lifeless, the work of God's handshence we cannot pray to them or worship them."

"Officer: "Will you not pray to Andrianampòinimèrina and Radàma?"

"Christian: "Andrìnampòinimèrina and Radàma were worthy of reverence as sovereigns while here on earth; but as to worshipping them, that cannot be done, as the objects of worship cannot be increased."

' Officer: "Will you not worship Her Majesty Rabòdonàndrìnampòinimèrina ?"

"Christian: "Rabòdonàndrìanampòinimèrina is the sovereign appointed by God to be served and obeyed; but she is only human, hence we cannot worship her, we can only worship God."

"Officer: "Won't you take the oath ?"

"Christian: "We cannot do so, and we have vowed not to do so."

"Officer: "Do you still regard the Sabbath day as sacred, and abstain from all work on it ?"

"Christian: "The Sabbath is a day set apart for the service of God; during the six days we labour 
and do all our work, but we still hold the Sabbath sacred."

"Officer: "Why do you say that you will not worship or pray to any one except God; and yet you worship and pray to Jehovah and Jesus Christ?"

'Christian: "Jehovah and Jesus Christ are God under different names."

"One man was asked by the officer: "Who are your companions, fellow ?" To whom he replied: "You and all the people on the earth are my companions." This same man strengthened his fellow Christians by saying: "Be not afraid of them who kill the body, but are not able to kill the soul; but rather fear Him Who is able to destroy both soul and body in hell."

' On Wednesday, March, 28, I849, a proclamation was issued and read at Anàlakèly condemning the eighteen Christians who had refused to give up praying to Jesus Christ and worship the idols. It ran-" Concerning these eighteen brothers and sisters whom I have interrogated and examined: they will not follow the doings of you the majority of my subjects; therefore I shall put them to death. Some of them shall be burned at Fàravòhitra, and the rest I shall fling over the precipice." When the condemned heard the sentence, they began singing a favourite hymn: "We are going home, O God."

'The Christians were mocked, jeered at, and vilified by their fellow countrymen, called traitors to their fatherland, and worshippers of the "white man's ancestor ${ }^{1}$." '

'The sentences of the queen upon the offenders were divided into classes, according to their rank or their crimes. The four nobles, two of whom were husband and wife, were sentenced to be burned alive at Fàra-

${ }^{1}$ Native Narrative of the Persecutions. 
vòhitra, at the northern end of the hill on which the city is built ; and they were burned under circumstances of cruelty which dare hardly be described. The fourteen others of inferior rank were sentenced to be hurled from the edge of Ampàmarinana, a precipice to the west of the palace, and their wives and children sold into irredeemable slavery. The total number of those on whom one or other of the sentences was pronounced on this occasion amounted, at the lowest computation, to $\mathrm{I}, 903$, but by some accounts it is nearer 3,000 .

'The soldiers took up the four nobles, and carried them from the plain up the hill-side to Fàravòhitra, to a place on the highest part of the hill. As they were carried along they kept on with their hymn-singing. Thus they sang until they reached the spot where four piles of firewood were built up. They were then fastened to stakes in the centre of the piles above the wood. When the piles were kindled, and the flames were rising round them, they prayed and praised the Lord. Among the utterances then heard by those standing near were: "Lord Jesus, receive our spiritslay not this sin to their charge"; and, as if the visions of the future triumphs of the Lord were given to their departing spirits, one was heard to exclaim: "His name, His praise, shall endure for ever and ever."

One of the four burned was a woman, Ramàrindàlana, the wife of Andriampanìry, who was a preacher at Fìrènana, West Vònizòngo. The condition of this poor woman failed to move the hearts of her persecutors, She was about to become a mother, and actually gave birth to a child in the flames which consumed her and her offspring. Truly 'the tender mercies of the wicked are cruel.'

'Once, if not more than once, the falling rain extin- 


\section{'A Good Confession'}

guished the fire, which was rekindled; and to one of the sufferers (as we have said) the pains of maternity were added to those of the flames. While they were thus suffering, a large and triple rainbow-the sign of God's promise and faithfulness-stretched across the heavens, one end seeming to rest upon the spot whence the martyrs' spirits were departing. Some of the spectators, to whom the phenomenon appeared supernatural, fled in terror. One friend, who faithfully remained to the end, records of the martyrs: "They prayed as long as they had life. Then they died; but softly, gently. Indeed, gentle was the going forth of their life, and astonished were all the people around that beheld the burning of them there ${ }^{1 . "}$

The names of the four martyrs burned at Fàravòhitra were Ràmitràha, Andrìantsiàmba, Andrìampanìry and Ramànandàlana his wife.

'Among these so-called criminals who perished at the stake were some, as we have seen, of the highest rank, in whose veins the blood of former kings was supposed to flow. In the same order and manner in which they had been brought to receive judgement the remaining fourteen confessors (all of whom were from the province of Vònizòngo) were taken along the public streets, through the crowds in the city, the agitated and deeply affected crowds, to the top of the rock at Ampàmarìnana, the Tarpeian rock of Antanànarìvo. There on the top of that lofty precipice, at the edge of the western crest of the hill on which the city is built, the filthy fragments of matting wrapped round their bodies were removed. Their arms still remained pinioned and their ankles bound. Thus bound they were rolled in mats, carried one by one to the edge of the precipice

${ }^{1}$ Ellis, The Martyr Church of Madagascar, pp. 168-7r. 
and rolled over the downward-curving edge, whence they fell fifty feet, striking a projecting ledge, bounding off, and then falling upon the jagged and broken fragments of granite lying at the base of the precipice, some two hundred feet below the edge from which they had been hurled ${ }^{1}$.'

'One of them, before he was rolled in the matting, asked permission to stand up and view once more the striking scene before him, as from that spot the country can be seen for some sixty miles in three directionswest, north-west, and south-west. His request was granted; he rose, feasted his eyes for a few moments on the familiar scene, and then bowed his head in prayer. He was then rolled in the mat and hurled over the precipice. As his body descended to the rocks below he was heard singing ${ }^{2}$ '

Another, Rainiàsivòla, after being rolled over the edge of the downward-curving rock, was caught by the thorns which grow out of a fissure of the rock, some twenty feet below the edge. The officers who had rolled him over were in mortal terror, for it seemed as if their commission was not to be accomplished, and they might have to answer with their own lives for its failure. Lying there among the thorns on the edge of that precipice, the man must have looked up and seen their trepidation; for he shouted up to them: 'Don't be needlessly alarmed; I will wriggle myself clear and roll myself over!' By violent exertion the thorns were snapped, he was freed, and fell upon the jagged rocks below, where he lay a mangled corpse. That man had been idol-keeper and diviner to Razàka-Ratrimo, the father of Rànavàlona II, the first Christian Queen

1 Ellis, Faithful unto Death, pp. 153-4.

2 Native Narrative of the Persecutions. 
of Madagascar; but after his conversion he made firewood of the idol, and, as we have seen, died a martyr for his faith in Jesus Christ ${ }^{1}$.

'Ranivo, an interesting and beautiful young woman of one of the first families, for she belonged to the tribe or clan from which the reigning family traced their descent; the queen herself, therefore, wished to save her. When questioned she said: "I cannot serve the idols: God alone will I serve, as long as my life shall last; for God alone has given me life and spirit-a higher spiritual life to worship Him; and for that reason I worship God."

" "You are wrong in your mind, or ill," said the examining officer, "or you are under some charm; and you should consider well lest the queen hate you, and you should destroy yourself for no purpose."

" "I am not deranged," she replied, "nor am I ill." Then addressing her father, who was present, she said: "You indeed love me, $\mathrm{O}$ father, but God has given me a spirit to worship Him, and I should be filled with fear if I were to cease to pray to Him ; therefore I shall not cease to worship Him, lest I should die everlasting death."

" "Bind her!" said the officer; and she was bound like the others.

' The queen, anxious to save her, had with that view ordered her to be placed so that she might see her fellow Christians hurled from the fearful height, expecting that that would frighten her into submission. After they had all been hurled over, she was led by the executioner to the edge of the rock, and directed to look down upon the mangled bodies of her friends. She did so, but the sight did not lead her to waver in mind; for she still declined to take the required heathen

1 Native Narrative of the Persecutions. 
oath necessary to save her life. "Dispatch me," she said, "for my companions have already gone." Her relatives entreated her to comply with the queen's demand, and so save her life; but she said she could not take the oath, and she preferred to follow her martyred friends. They thought her insane, and reported to the queen to this effect, and hence her life was saved ${ }^{1}$.'

A younger brother of Ranivo was a great friend of mine for many years, and I got him to write a sketch of the life of his sister for our Malagasy monthly, Good Words.

'The mangled and scarcely lifeless bodies of Ranivo's Christian companions, who had been hurled over the precipice, were dragged to the spot on the top of the Fàravòhitra hill, on which the four nobles had been burned, and there consumed in one vast pile. The lurid flames of this funeral pyre were intended to spread awe and terror among the inhabitants of the numerously peopled villages around from which they were visible?

While Ràmitràha was in prison his mother visited him, and is said to have urged him to promise to pray to the idols sometimes, seeing that they were ' nothings,' and save his life; but he answered, 'I will not, I cannot.' I once asked Razàka, our native pastor at Fihàonana, and Ràmitràha's successor, in conducting the midnight prayer-meetings at Fihàonana, if he thought Ràmitràha's mother was a really good woman. He said she was one of the best Christian women he had ever known. 'For,' said he, 'her life was a testimony to her faith. She used to visit the sick, read the Scriptures to them, pray with them, teach the children, and do everything you could think of a good woman doing. In fact she was instant, in season and out of season, in every good work.' 'Well,

1 Ellis, Faithful unto Death, pp. 147-8.

2 Ibid., p. 155. 


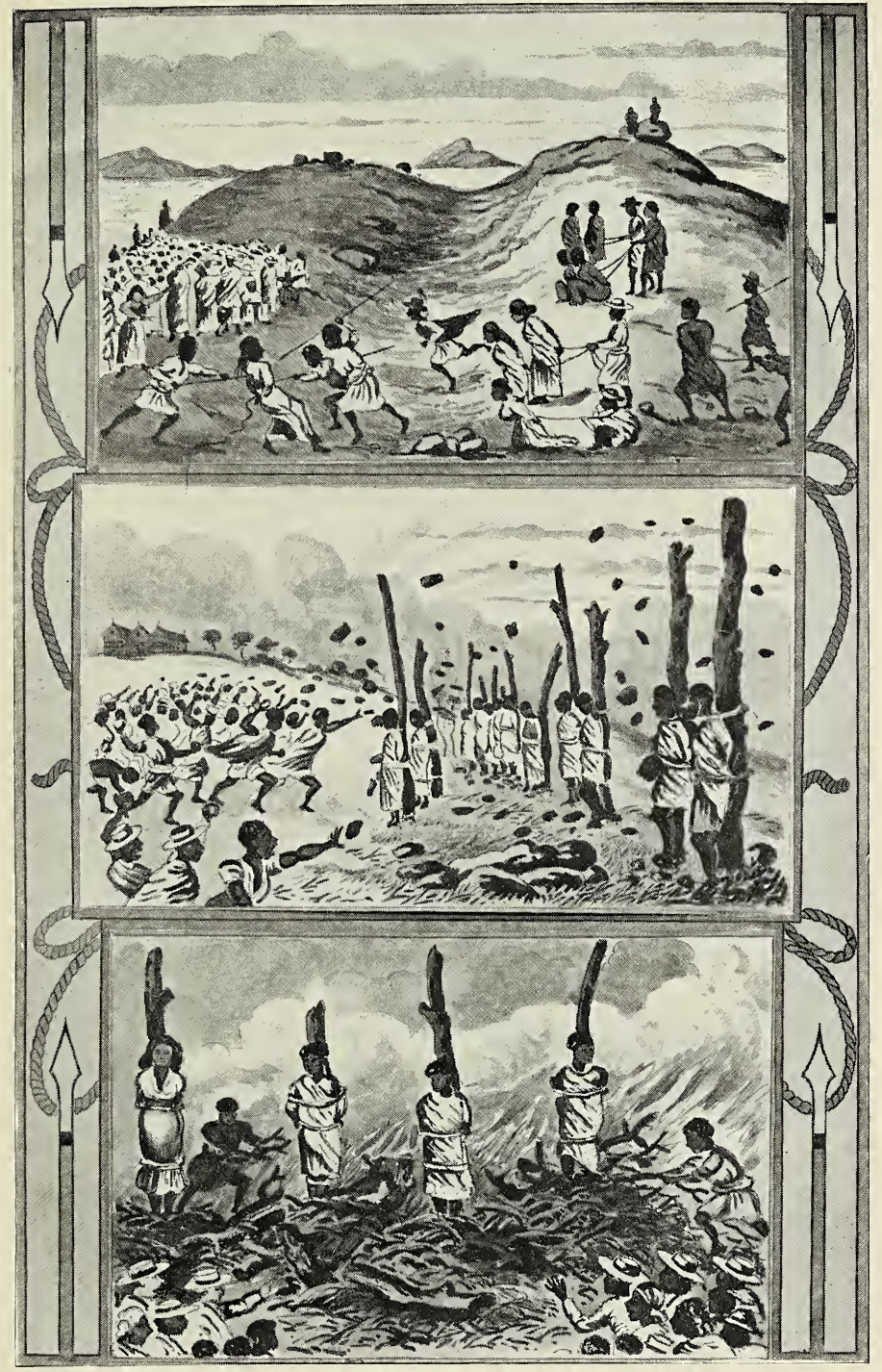

THE SPEARING AT AMBOHIPOTSY.

THE STONING AT FIADANANA.

THE BURNING AT FARAVOHITRA.

(From Native Sketches.) 

but,' I said, ' if she was really the good Christian woman you say she was, how do you explain her asking her son to promise to pray to the idols sometimes in order to save his life ?' He replied: 'I cannot explain it, sir ; but she must have half lost her senses through grief at the prospect of death to her first-born and much loved son; for I am quite sure that she was a truly good woman.'

Ràmitràha's younger brother, Andrìmpàrany, also visited him while in prison, and I asked him whether his brother seemed daunted at the prospect of death. 'Not at all,' he replied, ' he seemed rather to rejoice.' I had in my possession Ràmitràha's New Testament and some of the books of the Bible which had belonged to him; they were given to me by his widow, who was a member of my congregation at Fihàonana. To my intense regret they were lost by a friend in Scotland to whom I sent them. Her husband's death was a life-long sorrow to her till, in 1876 , pneumonia brought her release, the deaconesses and other Christian women soothing her last moments with hymns of faith and hope. Their only son, Rakòtovào, has been for many years pastor of one of the churches in the Fihàonana district. There was also a daughter, Rànàhy, who lived with a relation in the village of Fihàonana-a grey-haired, fine-featured, good old lady of one of the chief families of the district, 'an old disciple,' known as Rafàravàvifòtsivòlo-greyhaired Miss Last-born.

It was about this time at one of the midnight prayermeetings, held in the house of Rafàravàvy Maria in the capital, that Razàka and his wife were baptized and received into the church. He had been a pupil of the missionaries, had been expelled from his father's house for his adherence to the New Religion, and had his first wife (the wife his father and friends had provided for 
him) taken from him by her parents. They refused to allow their daughter to live with an outcast! He wrote his story for me, on condition that I should not publish it during his lifetime. After his death, in I884, it appeared in the Malagasy Good Words, and was afterwards issued in the form of a booklet, many copies of which have been given as school prizes. He told me that during the persecutions many of the Christians fled from the capital to Vònizòngo, and there remained in hiding for many a day.

After the martyrdom of Ràmitràha, Razàka secured the Bible which belonged to the small Christian community at Fihàonana, and with it carried on the midnight prayer-meetings, which Ràmitràha had begun. He once said to me: 'You know, sir, that often at those midnight prayer-meetings, when we read the Bible, we came upon parts we did not understand. We had no missionary to explain them.' 'What then did you do?' I asked. 'We read and re-read them,' he replied, 'prayed and re-prayed over them until we thought we understood them.' They used often, he said, to long for the rainy season, for a thunderstorm with its torrential rains, that they might be free to refresh their hearts with a hymn. In the central provinces of Madagascar some five months of the year pass without rain; but when the rains do come they descend in a deluge. Terrific thunderstorms usher in these tropical rains. In an hour and a half I have known three inches of rain to fall. In the lap of such storms the persecuted found freedom to worship God. The Malagasy are fond of singing, and sing well. Their language lends itself to musical expression. It has been called the 'Italian of the Southern Hemisphere.' It is soft, liquid, flexible, and rich in vowels.

'In 1853 the Rev. William Ellis, sent out by the 
London Missionary Society, and Mr. James Cameron from the Cape visited the port of Tàmatàve, but they were not allowed to journey to the capital. In June, I $8_{54}, \mathrm{Mr}$. Ellis again went to Tàmatàve, and during a stay there of some weeks saw many Christian refugees; and was enabled to do something to sustain the courage and the hope of the persecuted natives.

'In July, 1856 , Mr. Ellis visited the island again, was allowed to visit the capital, which he reached on August 25 , and where he stayed until September 26. He saw much to confirm the constancy of the disciples, tidings of which had reached England from time to time. While aware of the dangers to which the Christian natives were exposed, he and other friends of Madagascar were hopeful that matters would now improve, especially as the prince royal was known to be favourably disposed towards Christianity. But these hopes were speedily overclouded. In July, I 857 , a renewed and even fiercer outbreak of persecution occurred ${ }^{1}$.'

It has been asserted that the Christians who were stoned to death at Fìadànana and Fàravòhitra in July, I 857 , were political rather than religious martyrs; and one ill-informed clergyman has actually gone the length of saying that no Malagasy has ever been martyred for belief in Christianity! He affirms that any who suffered death did so because of their connexion with the Lambert and Laborde conspiracy-with which Ida Pfeifer, the famous German lady traveller, who was in Antanànarivo at the time, became involved-to dethrone the queen and place her son, the crown prince, afterwards Radàma II, on the throne. There is, however, not only not a vestige of proof for such an assertion, but the following extract from the Native Narrative of the Persecutions gives ${ }^{1}$ Lovett, History of the London Missionary Society, vol. i, p. 709. 
verbatim the queen's order for their execution and the reason for it. The royal order for their execution runs : ' They persist in the practice of the worship which I have prohibited, says the sovereign, and they are grieved, it is said, on account of those I have previously put to death, and state that I have executed as many as I,300 in one day. These are crimes worthy of death, and I inform you, O ye under heaven.'

Not a single word about any conspiracy - which would certainly have been referred to had there been any foundation for the above-mentioned reckless assertions. The names of all the fourteen who suffered are given in the Narrative, which says: 'On July 18 , I 857 , at Fiadànana (an open space a little to the south-west of the capital, and which can be easily seen from the palace-yard), they were stoned to death in the presence of an immense gathering of the people. They were first bound to stakes, and at the order "Fling!" a shower of stones darkening the sky almost like a cloud of locusts was hurled at them. All the fourteen were not stoned together at Fiadànana, only eleven, as Ràmahàzo, who was arrested after the others, was stoned by himself the following day; Ramànandàfy was pounded to death in his own house, and Rabètsàrasàotra, who was caught later, was stoned to death at Fàravòhitra on July 29, I 857. At the execution of all the Christian martyrs, but especially at the execution of those stoned to death at Fiadànana, everything was done calculated to rouse and excite the populace to the utmost. Bands with bugles sounding, big drums and kettledrums being beaten, and cymbals clashing, marched through the streets and lanes of the capital. The royal chanters and the conch-shell blowers paraded through the city, chanting the praises of the sovereign and sounding their shells. The cannon 


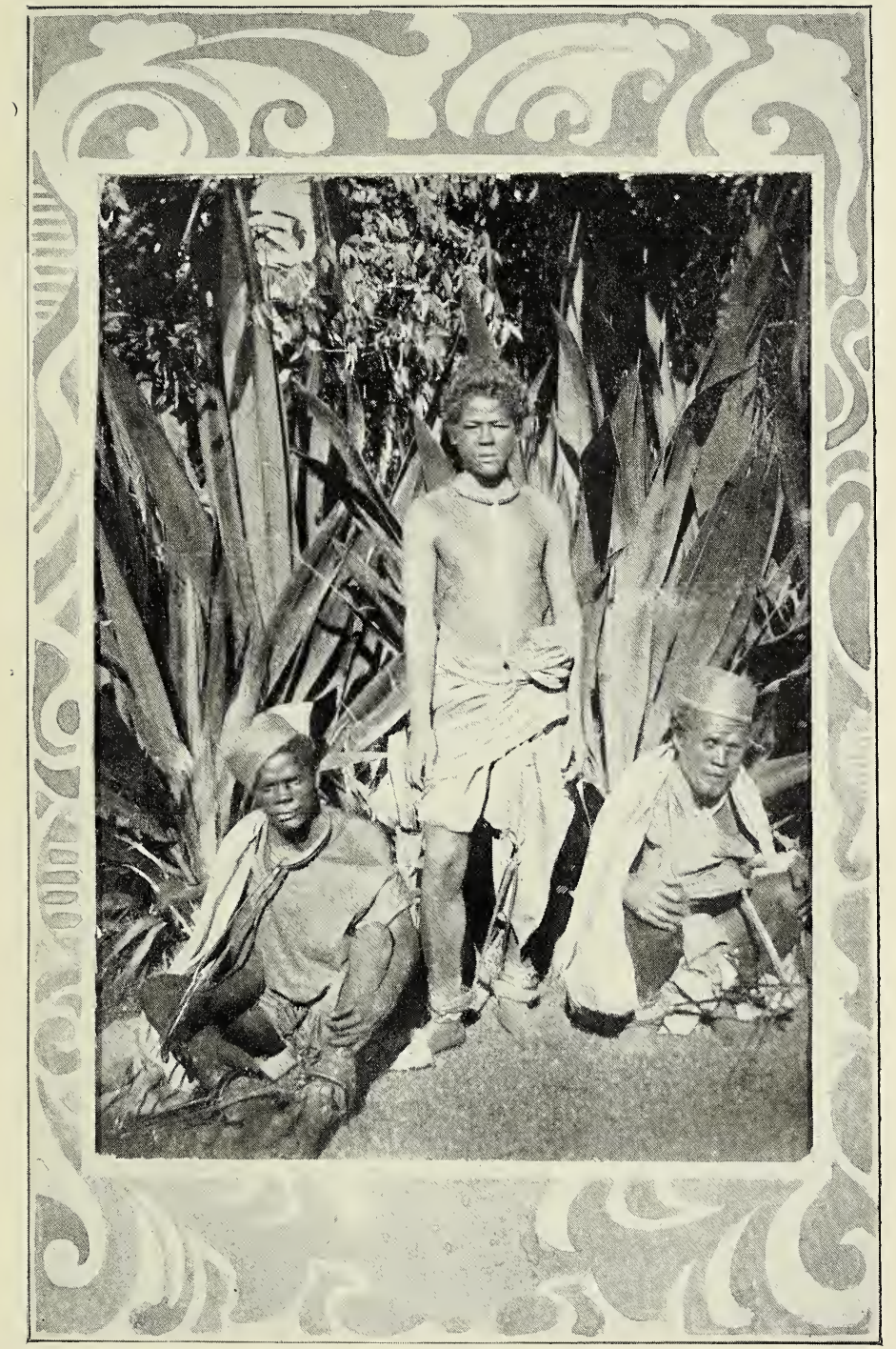

CRIMINALS IN CHAINS, ILLUSTRATING HOW THE MARTYRS WERE TREATED. 



\section{'They were stoned'}

roared from dawn to midday. An immense pile of Bibles, books of the Bible, Gospels, hymn-books, catechisms, and other Christian books was raised on a spot to the north of the palace and burned. The excitement and yelling of the people, who had been wrought up into a state of frenzy, was frightful to see and hear: the city was a perfect pandemonium ${ }^{2}$ '.

The cruel instincts of a people like the Malagasy, just emerging from heathenism, can only be gradually eradicated by time. It will take a long course of Christian training, through many generations-as in our own and other lands-to effect a permanent change. It augurs well, however, for the future of Madagascar that so much has already been accomplished in that direction in so short a time. Volumes might be written on the progress of Christianity during the periods of persecution, as it would take volumes to recount the sufferings of that evil time. Enough has been said, however, to indicate the baptism of blood and suffering which ushered in the new life of that benighted people. It is said that the darkest hour is that which precedes the dawn-and the dawn for Madagascar was at hand.

On Friday, August 16, I861, Queen Rànavàlona died at the age of eighty-one, after a reign of thirty-three years; or-as the Malagasy rather poetically put it-' she turned her back on the affairs of this life,' since they dared not say that a sovereign died. She ended her long life of cruelty and shameless immorality in the darkness of heathenism, without a ray of hope for the future to lighten up the gloom of the dark valley, while terrors of some kind-probably the superstitious horrors of a guilty conscience-seem to have tormented her

1 Native Narrative of the Persecutions. 
during her last hours ; as if the shadows from the swiftcoming eternity were appalling her, chilling her heart, and filling her soul with horrors.

Her reign was a veritable reign of terror, and lives as such in the memory of her people. They tell that when any of her fighting bulls died she had their carcases rolled in silk plaids and buried; but when her subjects complained of the severity of the forced labour which she demanded, she used to say: 'Make three of them!' that is, behead them and cut them through the middle! It is believed that during her reign some ten thousand perished from the poison ordeal alone. Her Christian subjects were treated as common criminals, and chained together by the neck by hundreds, a gang of them sometimes extending to nearly half a mile. If one of the gang died, the dead body had to be dragged along by the living, until the guard struck off the head and released them from the 'body of death.'

In the interior of the island, in the Bètsilèo country and wherever the Hovas had jurisdiction, criminals were kept in chains. Some of the condemned Christians were so treated. Prisoners had to earn their own living, and were only confined to prison during the night. On the days, however, on which the sovereign appeared they were not allowed to leave the prison; or if allowed out on those days, at noon, before the sovereign was to appear, they had all to return to prison, were counted and locked up. Why? Because if one of those criminals managed to secrete himself, and then emerged from his hiding-place to gaze at and salute the sovereign as she passed, wearing her diadem and beautiful in the glory of her royal apparel, he was a free man whatever his crime had been. His chains were at once struck off, for he had looked on the 
sovereign in her beauty and saluted her-the salutation being: 'Is it well with you, my sovereign?' and no one could do that and still remain a prisoner. 'Thine eyes shall see the king in his beauty' (Isa. xxxiii. I7); 'Whosoever shall call on the name of Jehovah shall be delivered' (Joel ii. 32).

Razàka informed me that when tidings reached the province of Vònizòngo of the queen's illness, he started for the capital with a beating heart. He felt that he was now on the threshold of liberty. When he arrived at the capital he sought out his old friend Andrìambèlo, the pastor of Ampàribè, Antanànarìvo, and asked: 'How is the queen?' He was told that she was very ill. Next day he called again and asked, and was told that she was at the point of death.

On the third day, while these old friends sat and discussed the possibilities of the future, they saw first one man run past the house, and then others. They went to ascertain the cause of excitement. They were then told that 'the queen had turned her back on the affairs of this life.' 'When we were told this,' he said, 'we could not speak. We took hold of each other's hands, looked each other in the face, and wept. This was all we could do. We wept for joy ; we were free.' I said: 'Did you weep for joy, Razàka, that the queen was dead ?' He answered: 'We did, sir, for we knew that we were free from our sufferings and our sorrows, and free to worship God when and where we pleased; and we wept for joy.'

On the death of the queen, Razàka and other worthy men who had been sold into slavery, put in chains, or banished to distant provinces for their faith, were set free, and they set to work to build up what had been broken down, and spread anew the Word of God. Much 
was done in that direction in the province of Vònizòngo, mainly by the labours of those men.

The dire persecution, which had lasted from 1835 , came to an end with the death of Queen Rànavàlona $I$, in August, I86r. Her son became king, as Radàma II, and the cruel laws against Christianity were repealed.

'Rànavàlona $I$ was the wife given to Radàma $I$ by his father, Andrìanàmpòinimèrina, the founder of the dynasty, with the express injunction that a child of his, of whom she should be the mother, should be his successor. Rànavàlona was neither the wife of his choice nor the mother of his children.' Her only child, Radàma II, had been born a year after her husband's death. It has been said that, cruel and heartless as Rànavàlona was, she was not incapable of acts of personal kindness. She had climbed to the throne over the murdered bodies of the lawful heirs to it, and ' her position as a despotic queen called into exercise her fiercest passions and her indomitable will-both being fostered and intensified by the superstitions of her country and her time. She was declared to be the divinity incarnate, invested with absolute rule and resistless power. In the overruling providence of God, this woman became the means of testing, purifying, and strengthening in her country that divinely implanted faith which the chief energies of her life were employed to destroy.' 


\section{CHAPTER III}

\section{FROM DARKNESS TO DAWN}

'The people that walked in darkness have seen a great light: they that dwelt in the land of the shadow of death, upon them hath the light shined.'-ISAIAH ix. 2.

'WITH the accession of Radàma II a new era in the history of Madagascar began. For although not himself a Christian, he had long been recognized as the friend and protector of the persecuted Christians; and one of his first acts, as King of Madagascar, was to proclaim religious liberty, a blessing so earnestly desired by hundreds of his subjects, but so persistently denied by his mother ${ }^{1}$.

'The reopening of Madagascar to the Gospel stirred up in other churches a strong desire to share in Christian work. Even before the arrival of the Rev. William Ellis (who had been sent out by the Directors of the London Missionary Society to reopen the mission), Roman Catholic priests and workers had reached the capital. From the first these agents pursued the invariable policy of Rome. They denounced Protestantism, they attempted to secure the direction of affairs, and they showed no scruples in the means they used to secure their ends.

' French political agents were also already on the

${ }^{1}$ Cousins, A Brief Review of the London Missionary Society Mission in Madagascar from I86I to 1870. 
spot, and active in their efforts, only too successful, to gain an influence over the king, and to aggrandize France. The French Consul was M. Laborde, and in close association with him was M. Lambert, who, in 1857 , had been banished along with $M$. Laborde and others by Rànavàlona because detected in a plot to dethrone her. Mr. Pakenham, the English Consul_ " the degenerate son of a noble sire, married to a low French-Creole woman "contrary to all reasonable expectation, took the side of the French as against Mr. Ellis, and did all in his power to lower the missionary's influence and weaken his authority ${ }^{1}$.

' On September 23, 1862, in the presence of an immense gathering of natives, and a fair number of Europeans, including the English and French embassies, Radàma II was crowned. At that time he appeared to be almost the idol of his people; and little did those present at the ceremony of September anticipate that within eight months the reign that had been begun under such favourable auspices would come to a tragic and melancholy end. Had the weakness and instability of Radàma's character been better known and more fully considered, and had his dissoluteness and licentiousness been better known, the sad termination of his short reign would have produced far less surprise. His steady friendship for the persecuted Christians, his hatred of bloodshed, and his desire to stand well in the estimation of Europeans are well known. But the darker side of his character seems never to have been known or understood by those most interested in his career. A halo of romance was consequently thrown around the youthful king in the imagination of many; and hence the violent shock and bitter disappointment caused by his death. 1 Lovett, History of the London Missionary Society, vol. i, p. 714. 


\section{A Ruined Josiah}

A juster estimate of his character has probably long since been formed by those most interested in Madagascar. Probably, however, there still lurks in the minds of some the idea that the character of Radàma underwent a more rapid deterioration than was actually the case; and that during the early part of his short reign he was one of whom it might have been said that he was "not far from the Kingdom of God." Such a favourable view of his character is, however, utterly opposed to facts but too well known in Madagascar.'

While the above statements from the pen of my friend the Rev. W. E. Cousins are no doubt accurate, and it is also true that the Rev. William Ellis was greatly deceived as to the real character of Radàma, and grossly imposed upon, it is nevertheless a fact that the ruin of the unfortunate king was accelerated, and his untimely end much hastened, by the conduct of some who went to the capital to be present at his coronation and remained there, and aided and encouraged him in his downward course, and in the orgies practised in his palace. Things were brought to a crisis by the king insanely throwing all Malagasy law and tradition to the winds, and wishing to introduce and legalize the custom of duelling. It is said that the prime minister, the commander-in-chief, and the officers of the palace besought him on their knees with tears not to introduce such a practice; but he would not relent. The prime minister deliberately asked him: 'Do you mean to say that if two men quarrel, they can go out and fight with swords or pistols, and if one kills the other the murderer shall not be punished?' To which the king replied: 'That's it, that's exactly what I mean.' The prime minister then said: 'But we cannot have that.' To that the king replied: 'But $I$ will have it; I am the king, and 
I shall have what I please.' 'That is enough,' said the prime minister. 'It is time for us to see to our own interests,' and left the palace. The obnoxious order cost the king his life.

'In estimating the effect of Radàma's policy upon the Church of Christ in Madagascar, it must be acknowledged that his thorough hatred of restraint of every kind, and the absolute freedom granted by him to all classes of his subjects, allowed the long repressed power of Christianity to assert itself, and by its rapid progress to take such a firm hold upon the people of the central province of Imèrina as to convince the government of the folly of again attempting a policy of repression.

' Radàma II was succeeded by his widow, Rabòdo, who was proclaimed queen on the afternoon of the day on which her husband was assassinated, under the title of Ràsohèrina. Before she was proclaimed, a paper was presented to her by ministers, advisers, and officers containing seven articles, one of which set forth the terms upon which she would be acknowledged as queenthat CHRISTIANITY SHOULD NEVER MORE BE FORBIDDEN OR HINDERED BY THE GOVERNMENT OF MADAGASCAR! It was generally understood that that was mainly, if not entirely, the work of the late prime minister. The new queen was personally unfavourable to the Christian religion; but during the five years of her reign she never openly deviated from that agreement, the acceptance of which was made a condition of her assuming the crown. In many respects the reign of Ràsohèrina was a period of retrogression, and the Christians were often troubled by the fear of another outbreak of persecution.

'At several of the great kabàries, or public assemblies, held at various times during the reign of Ràsohèrina, 


\section{A Queenly Request}

messages hostile to Christianity were sent to her by representatives of some of the more important places. But her uniform answer to such messages was that she was determined not to depart from the policy of toleration with which her reign began. Towards the end of the reign of Ràsohèrina a more steady confidence gained ground among the people; and Christianity continued to make slow but real progress. Treaties of friendship were made with Great Britain (signed June 27, 1865), and with America (signed February 14, 1867); and thus the fears of any breach between Europeans and the Hova government, and of any consequent hostility to Christianity, were dispelled.

- A French treaty was under consideration in Ràsohèrina's reign; but was not finally agreed to till August 8 , I 868, some months after the accession of Rànavàlona II.' To the honour of Great Britain and of Britain's late noble and beloved Queen be it told, 'that the British Consul, who negotiated the treaty of friendship, was charged with a special personal message from Queen Victoria, asking that, as an expression of friendship to herself, the Queen of Madagascar would not allow the native Christians to be persecuted on account of their religion. This noble request had the desired effect, by securing the insertion of the toleration clause in the treaty: "Her Majesty the Queen of Madagascar, from her friendship for Her Britannic Majesty, promises to grant full religious liberty to all her subjects." This will form, in the estimation of many, one of the brightest jewels in the crown of the late great Queen, whilst it will remind some of the memorable message sent from Windsor Castle by Queen Adelaide in March, 1837 , to the persecuting Rànavàlona I: "Tell the Queen of Madagascar from me, that she can 
do nothing so beneficial to her country and her people as receive the Christian religion ${ }^{1 . "}$."

Thus, from $186_{5}$ to 1896 , the Malagasy people owed it to the late Queen Victoria that they enjoyed (what they once more enjoy) the fullest religious toleration. It was little wonder, therefore, that they had the most extraordinary admiration and veneration for Her Majesty, though they could not understand how it was that she forsook them at the last-as they thought-and did not come to their help. I believe many thought that her prime minister, or some of her advisers, had told her lies about them, otherwise their great and good friend Queen Victoria could never have deserted them.

'Queen Ràsohèrina died on Wednesday, April I, I868; and early on the morning of Thursday, April 2. Ramòma, a first cousin of Ràsohèrina, was proclaimed Queen of Madagascar under the title of Rànavàlona II. No idols were brought forth when she made her first public appearance to the people on the balcony of the large palace; and no idols were to be seen at the funeral of Queen Ràsohèrina. From all that could be learned at the time, the new reign promised to be more favourable to Christianity than that of Ràsohèrina had been.

' The attempt that had been made to change the government had failed; but the strong desire on the part of the people for more liberal measures had been clearly shown; and the rulers of the country saw that they had been standing upon a mine ready to explode at any moment, and that their continuance in power must depend upon their keeping in harmony with the advancing ideas of their people ${ }^{2}$ '

Things had come to a crisis, and the rulers of the

1 Cousins, A Brief Review of the London Missionary Society Mission in Madagascar from I86I to I870.

2 Ibid. 


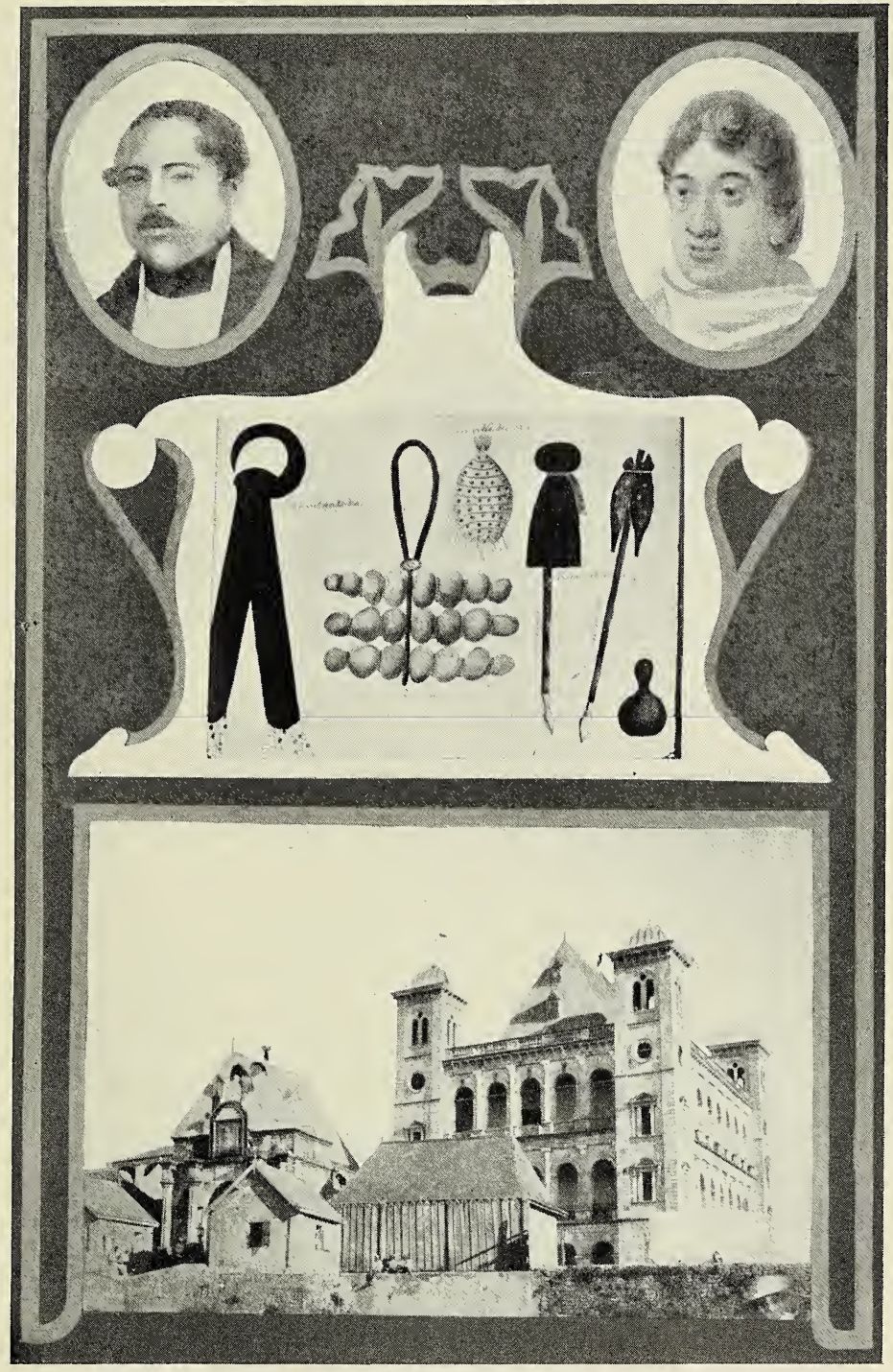

RADAMA II.

RADAMA I.

THE ROYAL IDOLS OF MADAGASCAR.

THE PALACE, ANTANANARIVO. 

country had to make up their minds either to lead the people or be led by them. They could not afford to follow, so they were bound to lead them. Various changes were accordingly made. The new queen had in early life been interested in Christianity, and much impressed with the truths taught her by her nurse, a slave woman in her father's household and a secret Christian, who sometimes took her young mistress to a midnight prayer-meeting. She had also felt the power of the words secretly read to her from the Bible by one of the native preachers; and a Bible, or some books of it, were said to have been hid for years in one of the corners of her father's courtyard.

Little did that poor slave woman and native preacher dream of the service they were rendering future generations and the Kingdom of God by their efforts to fill the mind of that young princess with the truths of Christianity. The good seed of the Kingdom, which had been sown in her mind, seemed for years as if it had been choked by the corruptions of the court of her aunt, Queen Rànavàlona I, and kept from bringing forth fruit by the persecutions of those terrible times. The truth was not dead, however; for the announcement that she was to be the future queen seemed to have quickened it into life, and to have led her to think seriously of the opportunity soon to be hers of serving God and His Cause, by taking a stand for Him and His Word. She informed her officers that she meant to worship the true God, and she began her reign by having family worship in her palace morning and evening.

' One by one there came indications that the queen and the prime minister would declare themselves Christians. At the coronation of the queen, which took place on September 3, 1868, the declaration in 
favour of Christianity was unmistakable; for the people were told in the royal proclamation (art. 8) - "And this also is my word to you, ye under heaven, in regard to the praying: it is not enforced; it is not forbidden; for God made you."

"Rànavàlona $I$, the cruel persecuting queen-the "Bloody Mary" of Madagascar-had done her best to burn and destroy all the Bibles in the land; but Rànavàlona II, the Christian Queen of Madagascar, had a Bible placed on a table at her side in sight of the thousands of her subjects, gathered from all parts of Madagascar to be present at her coronation. And thus for the first time the Bible and the crown were associated in Madagascar.

'The reign of Rànavàlona I was one of terror and bloodshed; but at the coronation of Rànavàlona II the words-"Glory to God"; "Peace on earth "; "Good will among men"; "God shall be with us" were inscribed in letters of gold on the canopy under which her throne was placed. These things augured well for the progress of Christianity, and time proved that they were not mere empty symbols, but that Rànavàlona II and her very able and enlightened prime minister were most anxious to see Madagascar a Christian country; and a succession of most important events afterwards made this evident to all ${ }^{1}$ '

' On the Sabbath, October 25, 1868, a religious service was begun in the palace for the benefit of the queen and prime minister and their attendants. From the beginning, up to April, r88o, this service was conducted by native preachers only. Probably some fear of difficulty with the French kept the queen from asking

${ }^{1}$ Cousins, A Brief Revierw of the London Missionary Society Mission in Madagascar from $186 \mathrm{I}$ to 1870. 


\section{The Christian Queen}

any of the British missionaries to take part in the services. About the same time as the palace service was begun all government work was stopped on the Sabbath. The various markets formerly held on the Sabbath were ordered to be changed to some other day. Proclamations were made throughout the country to the effect that the queen commanded the people to abstain from all work on the Sabbath; and on February 21, 1869, the queen and the prime minister were publicly baptized ${ }^{\text {.' }}$

On July 20, 1869, the foundation-stone of a chapel royal was laid, and in the cavity the following statement was placed :-

'By the power of God, and the grace of the Lord Jesus Christ, I, Rànavàlona, Queen of Madagascar, founded this House of Prayer on the I3 Adimizàna (July 20), in the year of the Lord Jesus Christ I 869, as a House of Prayer for the praise and service of God, King of Kings, and Lord of Lords, according to the word in the sacred Scriptures, by Jesus Christ the Lord, who died for the sins of all men, and rose again for the justification and salvation of all who believe in and love Him.

' For these reasons this stone house, founded by me as a House of Prayer, cannot be destroyed by any one, whoever may be sovereign of this my land, for ever and for ever; for if he (or she) shall destroy this House of Prayer to God which I have founded, then is he (or she) no longer sovereign of my land Madagascar.

'Wherefore I have signed my name with my hand and the seal of the kingdom.

'(Signed) RÀnAVÁLOMANJÀKA, 'Queen of Madagascar. 
' This word is genuine, and the signature by the hand of Rànavàlomanjàka is genuine,' (says) Rainilaiàrivòny, prime minister and commander-in-chief of Madagascar.

'Mr. William Pool, of the London Missionary Society, made the designs for this house of prayer ${ }^{1}$.'

The building, when finished, was publicly opened by the queen in person, on April 8, 1880, when missionaries of the London Missionary Society and the Friends' Foreign Mission Association preached and presided, having been requested to do so by Her Majesty. After the first day of the opening, the chapel royal was thrown open to the congregations of the twenty sections, or districts, into which the mission of the London Missionary Society and the Friends' Foreign Mission Association were divided, and Her Majesty worshipped there with her people in her own chapel royal every day for twenty days! The chapel royal is certainly a beautiful building, and reflects the greatest credit upon the late Mr. W. Pool, the architect and builder for the London Missionary Society in Madagascar, by whom the plans were drawn, and who also superintended its erection, as well as upon the Malagasy workmen employed. It may also be very fairly said to have been ' a visible manifestation to all of the unhesitating manner in which the religion of the Lord Jesus Christ had been adopted by the rulers of Madagascar, and confirmed the truth of what Queen Rànavàlona II repeatedly stated on public occasions after her accession to the throne: "I rest my kingdom upon God!" '

On September 8, r869, Ikèlimalàza (the small but famous Sampy), the chief royal idol in Imèrina (the central province of Madagascar), was committed to the 1 Missionary Chronicle (London Missionary Society), Jan. 1870. 


\section{Burning the Idols}

flames by the orders of Rànavàlona II, Queen of Madagascar. During the remainder of the month of September, a general burning of idols and charms took place all over the provinces of Imèrina and Vònizòngo; and the great majority of the people, in those two provinces at least, destroyed their idols-the objects of veneration and terror for ages--without any great signs of grief at their loss.

Some seem to have thought that it was a mere matter of state policy on the part of the queen and prime minister to profess Christianity when they did. But, looking to her consistent conduct and earnest Christian character to the end of her reign, I believe that on the part of the late queen, at least, it was a matter of the purest and highest principle. But even if it had been a mere matter of policy, surely Christian policy, and the policy which brought such blessings to multitudes and to the Church of Christ, was a good thing for Madagascar.

The congregations, both in the capital and in the country districts, grew in numbers, and indeed were almost swamped by additions from heathenism or semiheathenism; while some six hundred village congregations were formed in various parts of the provinces of Imèrina, Bètsilèo, Antsihànaka, and on the coasts within twelve months. The people gathered together on the Sabbaths, but there was no one to preach, or even read the Scriptures to them. In some cases they met, simply sat quiet for a time in the building they had erected, and then dispersed; or they sang a hymn, or a verse of one, over and over again before breaking up.

From all parts of the country there came applications to the missionaries for teachers and preachers, which they could not meet. So that the work done during the last thirty years has been mainly that of teaching heathen, or 
semi-heathen, congregations what are the first principles of the Gospel of Christ. We have, however, had very apt scholars, and they have made extraordinary progress in many directions, and doubtless would have made even greater advance had they had better teachers. Much of the success has been due to the circulation of the Word of God among the people. For, although the majority of the missionaries have given their best and done their very utmost, still the sad thing has always been that we could never overtake a hundredth part of our work, or do it as we should have liked, and as it ought to have been done. How could we? Most of us had charge of a mother-church and the oversight of some sixty village congregations or preaching stations and day schools. In one case a hundred and twenty were reported to be, in a very nominal way, connected with one mother-church; and, the tie being so slight, the results were only what might have been expected.

The work has always suffered from its very successsuffered in depth from its vast extension, for it is hardly possible to have both depth and extension at the same time. It has also suffered somewhat, as was to be expected, from the imperfections of the native agents who had to be employed as pastors, local preachers, and evangelists. For while the majority of these did marvellously well, all things considered, and many of them were really gifted speakers, yet very few had had training of any kind or even much instruction. Most extravagant expectations were entertained of them and the work they could do, mainly because of their number and it seemed to have been quite forgotten how very recently they had emerged from heathenism.

Great mistakes have sometimes been made with regard to the Madagascar Mission. Many supposed that the 


\section{A Peaceful Revolution}

burning of the idols in Imèrina meant that all the Malagasy had been converted, and some have still the idea that the whole of Madagascar-an island four times the size of England and Wales-has been Christianized. Yet, as a matter of fact, only about one million-out of five-of those in the central provinces have been reached. The burning of the idols, which was greatly overruled for the glory of God and the cause of Christianity. in Madagascar, was indeed an event for which we have all the greatest reason to feel most profoundly thankful; but it by no means meant the conversion of all the Malagasy. And, notwithstanding all the good work done, two-thirds of the island is still in heathen darkness.

By burning the idols the Malagasy government simply assumed a new attitude towards Christianity and Christian civilization. The vast majority of the people in the central province of Imèrina and the adjacent districts and provinces followed the example set them by the queen and government; but they did so mainly from loyalty or fear, and not from any real heart-love for the Christian religion. Doubtless there were hundredsI should like to believe there were thousands - who were actuated by higher and nobler motives, some by the very highest and holiest, and who rejoiced and sincerely thanked God for the change of policy which $\mathrm{He}$, in His providence, had led the rulers of the land to initiate.

Still the fact remains that the movement was mainly a political one on the part of the majority of Her Majesty's advisers, and could in no sense be truly and honestly called 'the conversion of the Malagasy as a nation to God' by any one who understood the real state of the case. The Malagasy as a people were not 
converted at the burning of the idols. They and their rulers took up a new position with regard to Christianity, and made it no longer a crime to worship God. As a result of this, there was a large influx into the existing churches of semi-heathenism, while some six hundred new ones were formed in the province of Imèrina alone within twelve months.

The news of the burning of the idols reached the Directors of the London Missionary Society in London about the middle of January, I87o, and they decided to reinforce the Madagascar Mission by four new missionaries. On January I 7 I was asked if I would be one of the four, who were to sail the following month. I consented, and was told to go and prepare at once, as the vessel by which we were to sail was posted for February 26. I immediately set to work to get ready, and within a month was ordained and married, and had bought, packed, and sent off our outfit and stores, and said farewell to my friend James Gilmour and other friends. On the way to London, however, I had the misfortune to be struck down with typhoid fever, which detained us some six weeks longer in the country, so that it was not until April 6 that we sailed from Gravesend in the 'Sea Breeze' for Mauritius. I was in a very weak state when we left England, and did not derive much benefit from the voyage; consequently was not much stronger when we reached Mauritius.

We reached Mauritius on Sabbath evening, July 3, having been eighty-four days on the voyage from England; and we left Mauritius again for Madagascar on Saturday, July 9, reaching Tàmatàve on Thursday, July I4, and Antanànarivo on Saturday, July 30, fully five months from the time we left home. As might be expected in the circumstances, my journey from 



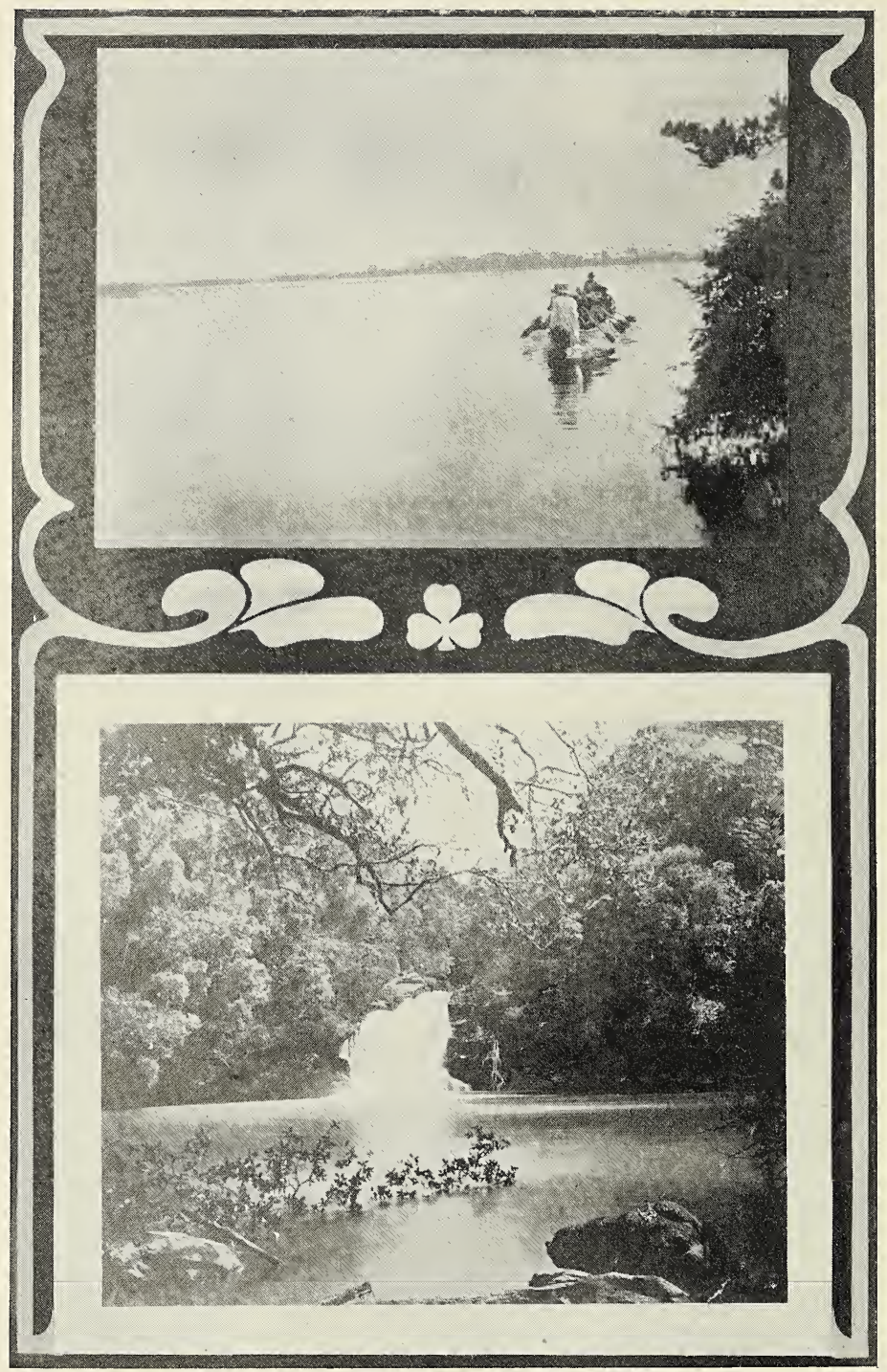

A RIVER SCENE AND A FOREST SCENE IN MADAGASCAR. 


\section{From Coast to Capital}

the coast to the capital was far from comfortable. For there are pleasanter experiences than being jolted on the shoulders of four bearers for over 200 miles, in a very poor apology for even a Malagasy palanquin, while suffering from an acute attack of sciatica.

We spent our first Sabbath in Madagascar, on our way from the coast to the capital, at one of the mission stations of the Church Missionary Society, where we had a very quiet, comfortable day, although unfortunately the missionary was from home. We had met him on his way to Tàmatàve, when he expressed his regret at being unable to entertain us in person at his station, and most kindly gave us liberty to occupy his house, and to make use of all we wanted. We attended most interesting native services in the mission chapel. Our journey up country, through the great forest with its thousands of orchids and tree-ferns, over the thickly wooded mountains, up the great river, and across the plains and plateaus, had all the pleasures of novelty, while the songs of our men, as they paddled us up the rivers, added to our enjoyment.

The climbing over the mountain ranges was very fatiguing. It was the cold season, when the south-east winds prevail, which render the nights on the plateau of Imèrina most piercingly cold, and we found them growing much colder as we penetrated further into the interior. As we could not speak to our men, we had to leave them to proceed in their own fashion, and carry us when and where they pleased. They were all fond of long journeys; but unfortunately all did not travel at the same rate. The palanquin-bearers kept rushing on, so as to get up to the capital as soon as possible; while the porters with the bedding, boxes, and provisions followed more slowly. On two occasions we 
did not reach the village where we were to spend the night until long after dark. One night the porters with our beds and provisions did not overtake us at all, and in consequence we had to go supperless to such beds as we could make for ourselves under the circumstances, had a very wretched night, and had to start next morning-a very cold, drizzly one-without our usual cup of coffee. This, and the night of torment we had suffered from mosquitoes and the other insects for which Malagasy villages are notorious, did not tend to put us in a very happy frame of mind.

At last, on the ninth morning of our journey, we saw Antanànarivo (' the city of a thousand men '- not townsthe full and original form having been Antanànarivolàhy), the capital of Madagascar, about forty miles away. We reached Ambàtovòy that afternoon, where we found a small European house, with a member of the Friends" Mission waiting for us. We entered the capital next day. We were met a few miles from it by the members of the London Missionary Society and Friends' Missions, who all gave us a most warm and hearty reception. We had reached our destination.

Central Madagascar can in no sense be called either picturesque or beautiful. Those who have described the bare plateau and bald hills of Imèrina as beautiful must either have an inaccurate notion of what constitutes beauty of scenery or must have viewed that portion of the island through a highly-coloured medium. As a general rule, not only is the central province of Imèrina without the two main elements of beautyvariety of outline and variety of colour-but the features are rarely so grouped together as to form any distinct or impressive combination. The tangled and almost featureless hills of the lowlands of Scotland 


\section{Central Madagascar}

afford perhaps the nearest parallel to them that I know; but even they are beauty itself, and picturesque in the extreme, when compared with the characterless hills, dales, and ditches of Imèrina.

It is only fair to say, however, that we saw Central Madagascar for the first time at its worst-in the middle of the cold season, when all is bleak, bare, and desolatelooking. In the early months of the year, after the first rains have fallen, when the young rice is appearing in the rice-fields, and the downs and hill-sides are covered with the fresh dark green grass, it is very different. It was at that season that the lamented Mr. Cameron, the war correspondent of The Standard, saw Central Madagascar in 1884, and although the beautiful little piece of word-painting, in which he tells us how it appeared to him, may seem slightly overdone, it is worth quoting, as the testimony of a man of such shrewdness and world-wide experience to the change that mission work had wrought over the once barbarous Hovas. He says :

'Antanànarìvo itself was in sight; and we could plainly see the glass windows of the palace glistening in the morning sun on the top of the long hill on which the city is built. It was Sunday, and the people were clustering along the footpaths on their way to church, or sitting on the grass outside waiting for the service to begin, as they do at home. The women, who appeared to be in the majority, wore white cotton gowns, often neatly embroidered, and white, or black and white, striped lambas thrown gracefully over their shoulders. The men were clad also in cotton-white cotton pantaloons, cotton làmbas, and straw hats with large black silk bands.

'In the morning sun the play of colours over the 
landscape was lovely. The dark green hills, studded with the brilliant red-brick houses of the inhabitants, whose white garments dotted the lanes and footpaths, contrasted with the brighter emerald of the rice-fields in the hollows. The soil everywhere is deep red, almost magenta in colour, and where the roads or pathways cross the hills, they shine out as if so many paint-brushes had streaked the country in broad red stripes. Above all, the spires of the strange city, set on the top of its mountain, with a deep blue sky for a background, added to the beauty of the scene. It was difficult to imagine that this peaceful country, with its pretty cottages, its innumerable chapels, whose bells were then calling its people to worship, and its troops of white-robed men and women answering the summons, was the barbarous Madagascar of twenty years ago '.'

${ }^{1}$ Quoted by the Rev. W. E. Cousins in Madagascar of To-day. 


\section{CHAPTER IV}

\section{THE MORNING BREAKING}

Arise, shine ; for thy light is come, and the glory of the Lord is risen upon thee.'-ISAIAH lx. I.

ON Friday, August 6, there was a meeting of the Imèrina District Committee, that is, the committee of management for all London Missionary Society affairs in Imèrina. I laid my instructions from the Directors of the London Missionary Society on the table, and asked for some one to go with me to Vònizòngo, in order to examine the district and see where it would be best, in the interests of the mission, for me to have my station. For although I was allowed by my instructions to remain for the first year at the capital, if I felt so inclined, and thought it would be of advantage to my work, or for my acquisition of the language, I was very anxious to go at once to my own station and become acquainted as soon as possible with the people for whom I had especially come. Our minds were made up accordingly to go on at all risks.

The Rev. W. E. Cousins, the senior member of the Committee, was asked to accompany me to Vònizòngo, and kindly consented. But before we could start, I was prostrated by another severe attack of sciatica, from which I suffered for four months, and was thus prevented from reaching Vònizòngo at all during $187 \mathrm{o}$, as by the time I was better the rainy season had set in. As it afterwards proved, however, this illness and disappointment were but blessings in disguise. 
Early in $187 \mathrm{I}$ we began to make preparations for proceeding to Vònizòngo ; but to this the doctors very strongly objected. They said I was quite unfit to face the fever of the west, adding that I little knew to what I was going, and in this they were perfectly right. As, however, we refused to abandon our determination to push on to our station as soon as the season would allow, the doctors ordered us away to the hills near the Great Forest for a month, that we might get somewhat braced up before starting for the west. We were on the hills during the month of April, and on our return to the capital, Mr. Cousins and I set out on a fortnight's tour in Vònizòngo. We went over the greater part of the district, and everywhere met with a very hearty reception.

The province of Vònizòngo is one of the central provinces of Madagascar, situated about forty miles to the north-west of Antanànarivo, the capital. It lies between two ranges of high hills, and is bounded on the north, south, and west by two large rivers, the Ikòpa and Bètsibòka, or to speak more precisely still, by two branches of one river, the Bètsibòka, or Kàtsèpo. Within these two branches of the Kàtsèpo lies Vònizòngo proper. It has no very extensive valleys (though in a sense about half of the province is one long, wide valley); but small fertile valleys abound, where large quantities of rice are grown. Like other parts of the island, the province formerly was split up into numerous subdivisions. The five most important places were Fihàonana, Fierènana, Ankàzobè, Isoàvina, and Miàntso.

Vònizòngo was never conquered, but the Andriandàhy, or "chiefs, submitted themselves to the rule of the Hova government on certain conditions. Originally the whole province was under a number of chiefs, or petty 


\section{Kinglet Pastors}

kinglets, very similar to the chiefs of the Scottish highlands in former times; and, of course, there was much intestine warfare. Every large village had its own chief or kinglet, who was lord and master of all it contained, either as slaves or vahoaka (clansmen). The people were almost at the absolute disposal of their chief, and hence generally followed blindly as he led to good or evil. In several cases I discovered that the chief had been chosen pastor of the church in his village, apparently for no other reason than that as chief of the village the people thought he ought to be also pastor and head of the church.

This arrangement, with all its drawbacks, was perhaps not the worst that could have been made, in the then ignorant and semi-heathen state of the people, and in the absence of proper men to undertake the duties of the pastorate. It must be remembered, and gratefully acknowledged, that to many of these pastor-chiefs the Church of Christ in Vònizòngo owed a great deal. Some of the most devoted of the martyrs came of their number, as Ràmitràha for one, and many of the most earnest and zealous of the pastors and preachers of our own time were also drawn from this class.

Vònizòngo was a province that had always been renowned for having an unusual number of petty chiefs. These generally claimed exemption from certain kinds of government service, such as digging, fetching wood from the forest, and assisting in building palaces for the sovereign. A number of these petty chiefs were chosen by Radàma I, to assist in cultivating some land at Foule Pointe, on the east coast, where he formed a colony ; and on the service being declined by them, as incompatible with their dignity as chiefs, Radàma lyielded the point ; but he still availed himself of their "services, by 
ordering that, as carrying a spade would be derogatory to their dignity, carrying a musket could not, and they must, therefore, honourably serve with the army in his wars. Hence there was a far larger number from Vònizòngo in the army than from any other province in the island.

The inhabitants of Vònizòngo were notorious in former times for their attachment to charms and idols. They have now for years been famous for their affection for the Gospel, their knowledge of it, and trust in it. In the year 1828 , three of the natives of this province were executed for making ody mahèry-powerful medicines or spells; in other words for being sorcerers. During the persecution, fourteen from Vònizòngo were put to death for their love to the Lord Jesus Christ.

From the time that the first missionaries arrived at Antanànarivo, in 1820 , a number of the people of Vònizòngo came into contact with them; and when they opened their first schools, they had several young men from the province as pupils, some of whom were for years among the most devoted pastors of the district. To certain of these, such as the late Razàka, the pastor of the mother-church at Fihàonana, we owed, under God, almost all that had been done in the province for the advancement of the Redeemer's Kingdom. I was told that Mr. Johns, who to the day of his death had a deep interest in Vònizòngo, first visited Vònizòngo in 1832 , when he gathered 'the seekers after God' into six small congregations, and afterwards began schools at Fihàonana, Fierènana, Ankàzobè, Miàramanjàka, Àndrambàzana, and İsoàvina.

The hut in which we lived for nearly two years in the village of Fihàonana, stood on the site of the hut in which the first small congregation used to meet thirty. 
nine years before our arrival. The mother of the chief of Fihàonana was the first convert, and her eldest son, Ràmitràha, became the first preacher to the small church. A third son was second pastor of the church at Fihànana whilst we were in Madagascar.

The people have always had the highest respect for the memories of these devoted missionaries who first carried the glad tidings of the Gospel to Madagascar. They often spoke most affectionately of them and their work. For the Rev. Mr. Johns and the Rev. Mr. Griffiths they entertained a more than ordinary regard. The year after the churches were founded in Vònizòngo, Radàma I died; but the churches seem to have made progress for some years. Even after the expulsion of the missionaries, when they were entirely at the mercy of Queen Rànavàlona $I$, they flourished and gained strength. When matters had assumed a really serious aspect at the capital, all was still quiet in Vònizòngo. This may be accounted for in part by the distance of Vònizòngo from the capital, in part also by the small numbers of government officials there, compared with the rest of the country.

After the mission was reopened in 1862 , Vònizòngo was visited for the first time by the Rev. W. E. Cousins. He paid a second visit in May, 1864 , after which visit he wrote: 'This district formed a hiding-place for many of those who fled from the capital, and from it many of the most steadfast martyrs came. Nothing would so rejoice the Christians of Vònizòngo as the appointment of a missionary to reside among them, and take charge of the churches in the district.'

Of course the people in most of the large villages were very anxious that the missionary should settle in their particular village; but after the most careful 
consideration of all claims we came to the conclusion that Fihàonana, 'The Home of the Martyrs,' where was located the mother-church of the province around which clustered so many sacred associations, memories of the martyrs and of the persecutions of former times, was decidedly the most suitable place for the new mission station, and every year of our stay in the island proved the wisdom of this decision.

Much preaching and teaching was done during this visit. We attended many gatherings of the pastors, local preachers, and deacons, and a great number of questions of all kinds were answered. Some of the questions put to us were of a somewhat curious nature. For example, I was asked: 'Who was the Queen of Sheba, and where did she come from?' 'How was it that Melchisedec had neither father nor mother?' 'Who were the brethren of the Lord?' 'How was it that Satan was allowed to fight in heaven?' That seemed to be a great difficulty with them, since they thought all fighting was finished here on earth, and how there could be fighting again in heaven was a great mystery to them. And then we were asked a very strange question, but one which showed more than all the others the stage in religious knowledge reached by the people at the time of our settlement among them. The question was: 'Whether the late Mr. Pool (the Society's architect and builder for Madagascar, whose name is pronounced by the Malagasy Powlie), and the Apostle Paul (also pronounced Powlie), who wrote the Epistles, were one and the same person!'

We found that one of the local preachers had been electrifying the district by a sermon, which consisted mainly of a dialogue purporting to have taken place in heaven between God the Father and God the Son, when 


\section{Theology and Discipline}

the Son, prompted by love, wished to leave heaven and come amongst men to seek and to save the lost. The Father was represented as remonstrating with the Son, and warning Him that mankind were intensely wicked; that they would treat Him very badly, and finally murder Him : and the Son as replying, that He knew all that very well; but such was His love for men, that although they were so very wicked, and although $\mathrm{He}$ was well aware they would put Him to death, and indeed just because they were so bad, He was determined to come and save them. And consequently, in spite of His Father's remonstrances, He left heaven, came to earth, suffered from privation and poverty, and finally was crucified by the very men He came to redeem. Nevertheless, by that same death the salvation of men had been made possible; for such was the Father's love for the Son, that He had agreed that all who believed on Jesus Christ as the Son of God, and accepted Him as their guide and friend for the future, should be saved with an everlasting salvation.

We also found, or rather were told, of an instance in which church discipline had been exercised after a new, and rather a drastic fashion, a few weeks before our arrival in the district. The Malagasy knew of no discipline except military discipline, which they had introduced into the church, and would have employed still, had we not arrived on the scene. The special case was this: A worthless character from the capital had been going through the district teaching hymn-singing. $\mathrm{He}$ taught so many hymns and tunes for so many dollars. $\mathrm{He}$ posed as one of the aides de camp of the prime minister, and this gave him a status in the eyes of the people which he otherwise would never have had. At the same time it ensured the prompt payment of his fees. At one 
of the villages he met with one as worthless as himself in the person of the wife of one of the deacons, and together they eloped. When this was discovered, a church meeting was called and the husband laid his case before the meeting. He said : 'Here is a servant of the church at large, whom you brought here. He has run away with my wife, and I think it is your duty to help me to recover her.' 'Yes,' they said, 'that is quite right,' and they thereupon appointed another deacon to accompany the husband and assist him in his search for his lost wife. They found out the direction the runaways had taken, followed, and found them sitting sunning themselves on a rock overhanging the river Ikòpa. They caught the man, bound him, rolled him up in his cotton plaid, tied the ends, and flung him from the top of the rock into the river. Then taking the woman with them, they returned and reported the church business finished ${ }^{1}$ !

Our visit to Vònizòngo in $187 \mathrm{I}$ was most memorable. I then met for the first time many of the early disciples, men and women who had fought a good fight and kept the faith all through 'the killing times,' and who had hazarded their lives for the Gospel, and suffered the loss of their little all for their loyalty to the New Religion. Some had been sold into slavery, while others had been put in chains, and others again had to flee for safety to the forest, or other parts of the island, or, like Razàka, had to hide for years in caves, or rice-pits, or dens of the earth. It was a joy to see

1 'The transition of any community from a state of repression to one of supremacy tends to change the character of the offences of which it takes cognizance. It accentuates the organization. It elevates the by-laws to a new prominence, and makes offences against them important.'-Hatch. 


\section{Memorials of the Past}

such noble men and women, headed by the noblest of them all, Razàka. I also met for the first time the widow and children-a son and daughter-of the martyr Ràmitràha, and the son of Àndriampanìry and his wife, who were burned along with Ràmitràha at Fàravòhitra.

We visited the famous small-pox hospital, the cave, in which the Bible was hidden for over twenty years, and Razàka for two. We also saw the small space inside the circle of immense boulders on the hill-side, where during lulls in the persecution from ten to twenty-five of the persecuted Christians met on the Sabbath mornings for worship. It thrilled one to see these truly sacred places, and to hear what the faithful band had to tell us of the sufferings of those times of strain and trial. We were given portions of the Scriptures, even leaves of the Bible, or of the Pilgrim's Progress, leaves of the hymn-book, tracts, portions of sermons, and catechisms, which had been kept all through the darkest days, and handed on from one to the other, and so had helped to support the faith of those suffering saints.

My friend and I had some memorable experiences during that visit to Vònizòngo. Of course, preachings, catechizings, interrogations, and deputations were abundant. Our experiences in the science of entomology were rather trying; but one of our greatest troubles was that our food was so badly cooked, and so smoked that we could hardly eat it. This was intentional on the part of the cook and his assistants, whose perquisite what food we left was; so we had to take measures to stop such practices.

We were not able to visit the Ankàzobè district, at the north end of the province, as malarial fever was raging there that season. All our porters were not 
vitatàzo, i. e. fever proof, so for their sakes and our own we were advised not to go, and returned to Fihàonana. The Malagasy have the idea that if once you have malarial fever severely and recover, you will never have so severe an attack again, and so will be vitatàzo. I have known a porter on a journey to the coast abstain from taking quinine, although he had it at hand, and deliberately run the risk of a severe attack of fever, since if he got over it he would be vitatàzo, and so fit to go anywhere.

There is no doubt something in this idea, as I have proved in my own person during the past twenty years; for after suffering greatly from malarial fever during the last five years of our first period of service, having been prostrated with it ten times, I have only had four mild attacks of fever since. It is necessary to state, however, that we have not lived in such a malarious district during the last twenty years as we did during the first ten. By exercising greater care, by taking quinine and a certain form of iron, and by other precautions, such as good food, wearing flannel, or lamb's wool underclothing, \&c., we have been able to keep ourselves as near normal health as possible. Once you get below par in the tropics, it usually means fever or something worse. Dr. Livingstone says that 'living in a malarious district, the whole tone is so lowered through the blood being poisoned, that you are not only liable to all the ills that flesh is heir to; but that if you do get any of them, you have it ten times worse.'

Having settled that Fìhànana was the right place for our work, we sought out a hut in which we could live until I built a house. We found a large mud hut, some twenty feet by twelve, in the centre of the village of Fìhòonana. Although it was far from what we would 


\section{Our First Home}

have liked in the way of a dwelling, it was the best to be had; so we took it, had it cleaned out, and the walls whitewashed. It was the ordinary mud hut of Central Madagascar, an oblong structure with mud walls, earthen floor, and a pillar in the centre for the support of the thatched roof. There was no ceiling, of course, and as the thatch was thin we suffered from the bitter east winds during the nights of the cold season. There were three small apertures in the walls, one at each side and one in the end, which served the purpose of windows, or rather wind-holes, for they let very little light into the hut. I had frames filled with glass fitted into these apertures, and this helped to keep the dust out of the hut, but did not increase the scanty supply of light.

As we were in the middle of a Malagasy village, our surroundings were not of the sweetest, especially as in those days the villages of Vònizòngo swarmed with pigs. Whenever we opened the door these creatures came into the hut. Of course I helped them out, to the astonishment of the natives, with whom the pigs were great favourites. People and porkers lived and slept in the same hut ; and to my remonstrances the people replied: 'The pigs help to keep the hut warm on the cold nights, sir.'

We found that enteric fever was endemic in the village; but I was able to improve things a little by having channels made from the stagnant pools and cattlepens to the fosse, from which the water drained away to a lake south-east of the village, and thus the rains of the wet season helped to cleanse the village and somewhat sweeten the atmosphere. It cost some trouble to get those channels cut, for the stagnant water with its coat of green slime on it had stood in pool and pen from time 
immemorial, and why make any change? One Sabbath afternoon, while we were all in church, a child toddled out of a hut and fell into one of the stagnant pools and was drowned. The mother, who was in the hut, heard nothing. She wondered why the little fellow had not found his way back into the hut again. On looking out to see where he was, she saw the body in the pool. An alarm was raised, we were called out of church, and did our best to restore animation, but we had been called too late.

A space of some six feet at the north end of our large hut was partitioned off by a low mud wall, and this we made our bedroom. We had besides two small huts; half of one was my study and the other half served as a storeroom, while the remaining hut was used as a kitchen. Everything was of the most primitive, makeshift, and inconvenient nature; but nothing else could be obtained until I could get a house built. When circumstances will not bow to mind, the only alternative is for mind to bow to circumstances, and make the best of it. This we did, and, all things considered, were fairly comfortable.

In 1873 the late Rev. Dr. Mullens, the then Foreign Secretary of the London Missionary Society, and the late Rev. John Pillans were sent by the Board of Directors to visit the Madagascar Mission. During the fortnight they spent with us in Vònizòngo, I took them down to see the village of Fìhàonana and our former habitation there. After looking into the hut, Dr. Mullens said: 'Well, you did write us some strongly worded letters about your need for a proper house; but I admit you had cause. We had no idea in London that you were living in a hovel like that, and amid such surroundings.' And yet we were no worse off than hundreds of missionaries who go to found new mission stations in 
other heathen lands. Those who spend all their missionary life amid the comforts and conveniences, such as they are, of city or sanatorium stations, know little of what life at lonely country stations in unhealthy districts means, and consequently do not always sympathize as they ought with others less fortunately placed.

A missionary's life at a lonely station, far from friends, fellow labourers, and human sympathy, is often very trying, but it is also one in which many useful lessons are taught more directly than they could be anywhere else, or in any other walk of life.

It was while living in the village of Fihàonana that my wife had her first severe attack of malarial fever, while our child had croup badly, followed by a severe attack of bronchitis, brought on by the bitterly cold night winds, from which our hut afforded us insufficient protection. In this connexion $\mathrm{I}$ am reminded of a splendid feat of one of our Malagasy men, who had been a servant of ours, but had fallen into disgrace and been discharged. When he heard that I wanted a man to go to the capital for medicine for my child, he volunteered to go, and ran to the capital and back, a distance of eighty miles, in fourteen hours! We took him back into our service, my wife trained him to be a good cook and a first-class baker, and he only left our service in 1898 to take up a temperance restaurant at Fìhàonana.

On July I2, I 87 r, we left Antanànarivo for Vònizòngo, and arrived that evening at Fihàonana, where we settled down to work. We lived and laboured there until driven away in July, I879, after many months of severe suffering from fever. The first and last years of our first term of service were trying indeed. In our first year my own protracted sickness, followed by my wife's 
dangerous illness, made it a specially trying time for us. Throughout our last year we had not a single month in which one or other of us was not prostrated by fever. We had two very bad fever seasons in succession in Vònizòngo, and lost some five thousand of our people. The interval between our first and last years was simply glorious. Full of our work, we flung ourselves heart and soul into it. We loved our work and our people, and were loved by them in return. As their first missionaries we were their first Rai-àman-drèny, 'father and mother.' They had several teachers after us, but none that they ever recognized in the same way as their Rai-àman-drèny.

Then our children were about us, and we were as happy and contented as could be. But after the first term of service it is always a very different story, for it is then but an impoverished, lopsided life that the missionary and his wife must live. He is a very fortunate man who is able to spend two years out of the next twenty with his family. Therein lies the sacrifice and suffering of missionary family life; and the children feel it most, for they miss their parents greatly, just at the very time when their help and advice would be of highest service. Good, kind, warm-hearted friends do much for the missionaries' children, and make such compensation for their parents' absence as is possible. Ninety per cent. of all missionary families have to suffer in this way (otherwise I should feel ashamed to mention the matter); and yet I question if ten per cent. of the members of the home churches, whose messengers, in a very real sense, the missionaries are, ever give a single thought to this side of missionary life.

Our first Sabbath at Fihàonana was one long to be remembered, for on that day I spoke for the first time 


\section{The Day of Small Things}

to my own people. The small chapel was quite full, although there were few present except the regular congregation. They were all clean, tidy, and attentive, and the only thing $I$ had to find fault with was that so many of them chewed tobacco, or rather sucked snuff, which they placed in their lower lip, holding it between the lip and the gum, and expectorated into spittoons, which were for the most part open tins or earthenware basins, or empty 'Day and Martin's' blacking bottles! I had only once to ask them to desist from such a filthy and objectionable practice in the house of God, though I had the greatest difficulty in putting a stop to the same thing twelve years afterwards in the city congregation of Ambàtonakànga.

We began a day-school at once, and my wife started a sewing-class. We had also a large Sabbath school class for young and old, for Bible reading on the Sabbath afternoons. My first schoolmaster was Rakòtovào, a fine, open-faced, manly fellow, who did splendid work in that school for some years, and then rendered still better service as an evangelist for many more. He and his two sons were carried off by some of his personal enemies, who accompanied the heathen mob which attacked Fihàonana during the rising in I 897 , and all three were shot--murdered in cold blood.

Our station school began with thirty, but went on increasing until we had two hundred and sixty. I did my utmost to get a school started in connexion with every village congregation, or preaching station, for from the first we recognized that in the children lay the hope of the future. My success, however, was by no means what I had expected; very few, except church members, would send their children to school, and as most of these were old, and their children quite 
grown up, we had but poor schools indeed for some years.

After a time I found out one reason for this reluctance on the part of parents who were only adherents to send their children to school. It was this. The year before our arrival in Vònizòngo, a Jesuit priest had passed through the province, and had tried to found some Roman Catholic stations, and to gather the children into schools. In his anxiety to get the children gathered in, he is reported to have said: 'We want not your children's bodies, but only their hearts.' Some old heathen, proud no doubt of his exceptional wisdom, explained to the people what that meant. He said: "Those white men are very clever and very cunning. They want to get the children gathered into schools, under the pretence of teaching them to be wise and good; but once they get them they will kill them, take out their hearts, dry them in the sun, and then reduce them to powder and make it into their medicine. For that is what their powerful medicine is made of, powdered children's hearts!' The ignorant people believed that story, hence their reluctance to allow their children to attend school. Later they became more enlightened, the more so after Queen Rànavàlona II issued her famous proclamation with regard to education.

Once settled at Fihàonana, I began visiting the outlying village congregations, eighty-four in number, of which I was supposed to be in charge. Although I was not able to do much in the way of preaching at each place, still I could give out a hymn to be sung, read certain chapters, and give a short address. The people everywhere were delighted to see me, always giving me a hearty welcome, and these visits did us all good. They listened 'with eyes and ears' to all I had to tell them 


\section{The Wonderful Story}

about the Gospel, the love of God, and salvation; for it was a wonderful story to them, and came to them with a freshness and an interest which those who have heard it from their infancy can hardly understand. That Andriamànitra Andrianànahàry, God the Creator, should think of them, and love them, and send His onlybegotten Son to seek and to save them, poor, degraded, besotted, sorcery-ridden Malagasy, amazed them, and they were never weary listening to the good news. Even to those of us who could tell the Gospel story only with stammering lips and another tongue for some time, they listened with a patience and a politeness that surprised and encouraged us.

I was not long in finding out how true the statement is that "There is a work to be done by missionaries which people in Christian lands hardly dream of. They have to create a moral sense before they can appeal to it-to arouse the conscience before they can look to its admonitions to enforce their teachings. Heathen consciences are seared, and their moral perceptions blunted. The memories scarcely retain anything we teach them; so low have they sunk, that the plainest text in the whole Bible cannot be understood by them. It is hard, until one goes to a heathen country, to realize how much civilization owes to Christianity.' I found when I came to teach my own children the elements of religious truth, how quickly they apprehended them as compared with the Malagasy children; but they had been born with a measure of a mental and moral nature to which the Malagasy children were utter strangers.

The Malagasy have the capacity of our Covenanting and Puritan forefathers for sermon hearing, and four sermons a Sabbath-two in the morning and two in the afternoon-of an hour each was the common thing, until 
the practice had to be abandoned for lack of preachers. My wife was often asked in those earlier days if I was quite well, because I had not preached quite so long as usual. Even to-day, the modern sermonette prepared for 'home consumption' would meet with but scant courtesy and little mercy at the hands of a Malagasy congregation.

In my visits to the outlying congregations of the district I was at first much struck with the appearance of many village pastors and their wives. They were nicely and neatly dressed. The husbands wore clean white cotton pants, white shirts, and white làmbas (cotton plaids); while the wives had pretty print dresses and white làmbas. After a few visits it occurred to me that there was a striking sameness about the dresses of the pastors' wives; but the obvious explanation was that they had probably all come from the same piece of print.

It was my custom at the first to visit the village congregations at their own request, or after sending them notice of my intended visit; but after a time I thought I should like to pay surprise visits, in order to see what their usual state was. I was astonished to find a sort of epidemic among the village pastors and their wives. Almost everywhere I went, on asking for the pastor I was told he was not well, and his wife also was ill. The epidemic did not seem to affect any one except the pastors and their wives. I soon found out the cause of all this pretended illness. When they were expecting my visit on the Sabbath, the pastor and his wife sent and hired proper clothing for the occasion; but when I arrived unexpectedly, they had no proper clothing in which to appear before the white man, and hence the feigned sickness. This also explained the sameness in 


\section{Original Preachers}

their attire; for the same gown, the same pants, and the same white shirt had done duty all over the district, having been hired for a few pence wherever and whenever wanted.

Previous to our settlement at Fìhàonana, some of the village congregations had been visited by strange preachers from the capital, who professed to be local preachers connected with one of the congregations there. Razàka told me how an impostor of this kind arrived at Fìhàonana one Sabbath morning. He was taken at his word, and invited to preach. He gave out a hymn, prayed, and then announced his text-a verse from the fortieth chapter of Matio (Matthew), pronouncing it Madio (clean). Razàka suggested Matio, but he persisted in saying Madio. Razàka then gently hinted that there were not forty chapters in Matio; but the preacher was quite equal to the occasion, for he replied: 'I don't know anything about your village Bibles, I go by the capital Bibles!'

The village churches on the long route from the capital to the port of Mojangà, on the north-west coast, were often victimized by these self-styled preachers. A worthless creature, with that gift of speech which so many of the Malagasy possess, would arrive at a village on a Saturday afternoon, pretending to be a local preacher from the capital, and probably adding that he was an officer of the prime minister's sons, or some palace official. Of course a deputation from the village church at once waited upon him, and invited him to preach next day. As a guest of the Christian community he received hospitality from Saturday to Monday at least, perhaps for a week, sometimes for a whole month. Some member, possibly a deacon's wife, or a deaconess, but generally one of the young women of the 
choir, was appointed to keep house for him, and this often led to grave scandals.

I was informed of this state of affairs by my colporteur, whom I had sent down to visit those remote churches. I immediately reported it to the committee in Antanànarivo. Printed certificates were prepared, which one of the missionaries in the capital, or I, was empowered to fill up, sign, and give to bona fide local preachers. I dispatched my colporteur again to Mojangà, with instructions to show a copy of the certificate to each church, and inform them that no one who failed to bring one of those documents duly signed was to be allowed to preach; nor was any one to be allowed to join them in the Communion Service, unless he brought a certificate of membership from the church to which he belonged.

While my colporteur was at Mojangà, the late Sir Bartle Frere visited the port. He landed on the Sabbath morning, worshipped, and joined in the Communion Service with the small native church there. The following May, being in London, he attended the annual meeting of the London Missionary Society in Exeter Hall, took a seat on the platform, and in the course of the meeting asked the chairman's permission to make a few remarks. In a graceful speech he testified to what he himself had seen of the fruits of the society's work on the north-west coast of Madagascar ${ }^{1}$.

${ }^{1}$ See Missionary Chronicle of the London Missionary Society, June, I884. 


\section{CHAPTER V}

\section{BREAKING UP THE FALLOW GROUND}

'A light for revelation to the Gentiles.'-ST. LUKE ii. 32.

From the first I had to give a good deal of medical advice to my people, and my work in that direction increased so rapidly that, finally, I had to confine medical work to one day a week, unless the case was very urgent. It is important that the majority of missionaries should know something about medicine-if only enough to impress them with its mysteries and their ignorance of its action, so as to keep them from prescribing unless they are pretty sure of their diagnosis. Medical skill is often of great service in the work and to the workers themselves. Besides, no native will believe that a European knows nothing of medicine. There is, however, a danger of a man being tempted (and many yield to the temptation) to give more time than he can afford to that part of his work, to the detriment of other and even more important duties.

Dentistry was very popular, for the Malagasy suffer much from toothache. One of their proverbs says: 'A worm in the tooth, there is no cure except extraction.' The Malagasy may almost be said to know nothing of nerves in our sense of the term; but I have seen a Malagasy young woman writhing on the ground under the agony of toothache, from which she only found relief on my extracting the tooth. One morning 


\section{Breaking up the Fallow Ground}

I drew three teeth, one after the other, for one woman, who never once winced, but, with her mouth half full of blood, simply said, 'Thank you, sir!' and walked away as if nothing had happened.

Operating upon others was easy enough; it was when one had to draw one's own tooth-as I had to do one Sabbath morning-that the difficulty came in. I had had a night of excruciating toothache, and in the morning was half beside myself with the pain. I was due that morning to preach at one of the outlying churches. I knew the people would be waiting for me, but while in such agony I did not feel fit to go. In my desperation I determined to have the offending tooth out. I wanted my wife to draw it, but she said she could not. 'Fix the forceps on it, then,' I said, 'and I will draw it myself.' She did as requested. I waited a little, then I wrenched the tooth out, flung the forceps from me, danced through the hut for a few minutes in agony, then all was over, and I mounted my palanquin, and went off to my preaching. Fortunately it was an upper tooth, otherwise I could not have succeeded.

Just after we had settled at Fihàonana, a boy was brought to me with his hand seemingly crushed to a pulp. At the entrance of the villages in the country a circular block of granite used to be rolled in between four upright pillars of the same material during the night to block the entrance. Sitting swinging upon one of these, he had got his hand crushed between the circular block and one of the pillars. When first I saw it I thought the whole hand was bruised to a jelly; but after soaking it for some time in tepid water I found that it was not nearly so bad as I had feared. The first joint of the middle finger, however, had been so crushed that I deemed it best to amputate it. I laid the lad 


\section{Surgery and Magic}

down on a mat at my own door, with a crowd of natives standing round, administered chloroform, took my knife and performed the operation. The hand was dressed and done up before consciousness quite returned. After all was over his friends asked the lad whether he had felt the vazàha (white man) cutting him. 'No,' he answered. 'Did he cut me?' he asked. 'Yes,' they said, 'he cut off the point of your finger.' 'I never felt him,' he replied. His confession caused the deepest wonder. 'What magicians these white men are!' the people said ; 'they just put a rag with a few drops of eau-de-Cologne' (eau-de-Cologne was the only liquid with an odour with which the Malagasy were acquainted) 'to a boy's nostrils, and off he goes to sleep, and they can cut him without his knowing anything about it.'

Of course an exaggerated account of this simple operation was spread abroad, and gave rise to an exaggerated estimate of my own powers and that of my medicine, which stood me in good stead for many years; although I only discovered this during the rising in 1897 .

In those early days, and even until 1896 , we had domestic slavery in Madagascar. It was, no doubt, the mildest form of slavery, and in most cases the slaves were regarded as almost members of the family and treated as such. Still slavery it was; and that is the sum of all villanies. When masters treated their slaves badly they ran away. In those days also the soldiers of the native army were soldiers for life, and received no pay. They had to maintain their wives and families as best they could; that was their business and not the government's. In consequence, many of the soldiers deserted, and one can attach small blame to the poor fellows who flung away their rifles and fled to the 


\section{Breaking up the Fallow Ground}

forests and joined the runaway slaves. Together they formed marauding bands, and dwelt for the most part in the forests of the far north. They made periodic raids on Imèrina, Vònizòngo, and the other provinces, and were a terror to many parts of the country.

A set of these freebooters pounced down one morning upon a large village near Fìhàonana, bound every man, woman, and child in it, and carried off all that they could lay their hands on-cattle, sheep, pigs, and poultry. The day following a man passing the village thought that it was very quiet, and entered to discover the reason. He found the inhabitants all lying bound in their huts. These robber bands often carried away women and children, especially those belonging to the Hovas, and sold them to the Sàkalàva tribe, or body of tribes, who inhabit some six hundred miles of the west side of the island.

One of my pastors came to tell me what had happened at that village, and to warn me of the approach of the band. I thanked him, but added that I was not at all afraid of their molesting us: but I did not know then, nor for many years after, to what we owed our exemption from their depredations. The report of my operation, and of the effects of the chloroform, had reached even them. They had been told that, if they went near that vazàha's house, even during the night, it would be the worse for them; for he kept most powerful medicine-had but to open his window, and fling it out, and all would fall down asleep, and by-andby wake up to find themselves all bound and ready to be sent as prisoners to the capital!

But even the mildest form of domestic slavery was utter ruination to all family morality. For, even in the days when polygamy was rampant, a man's female 


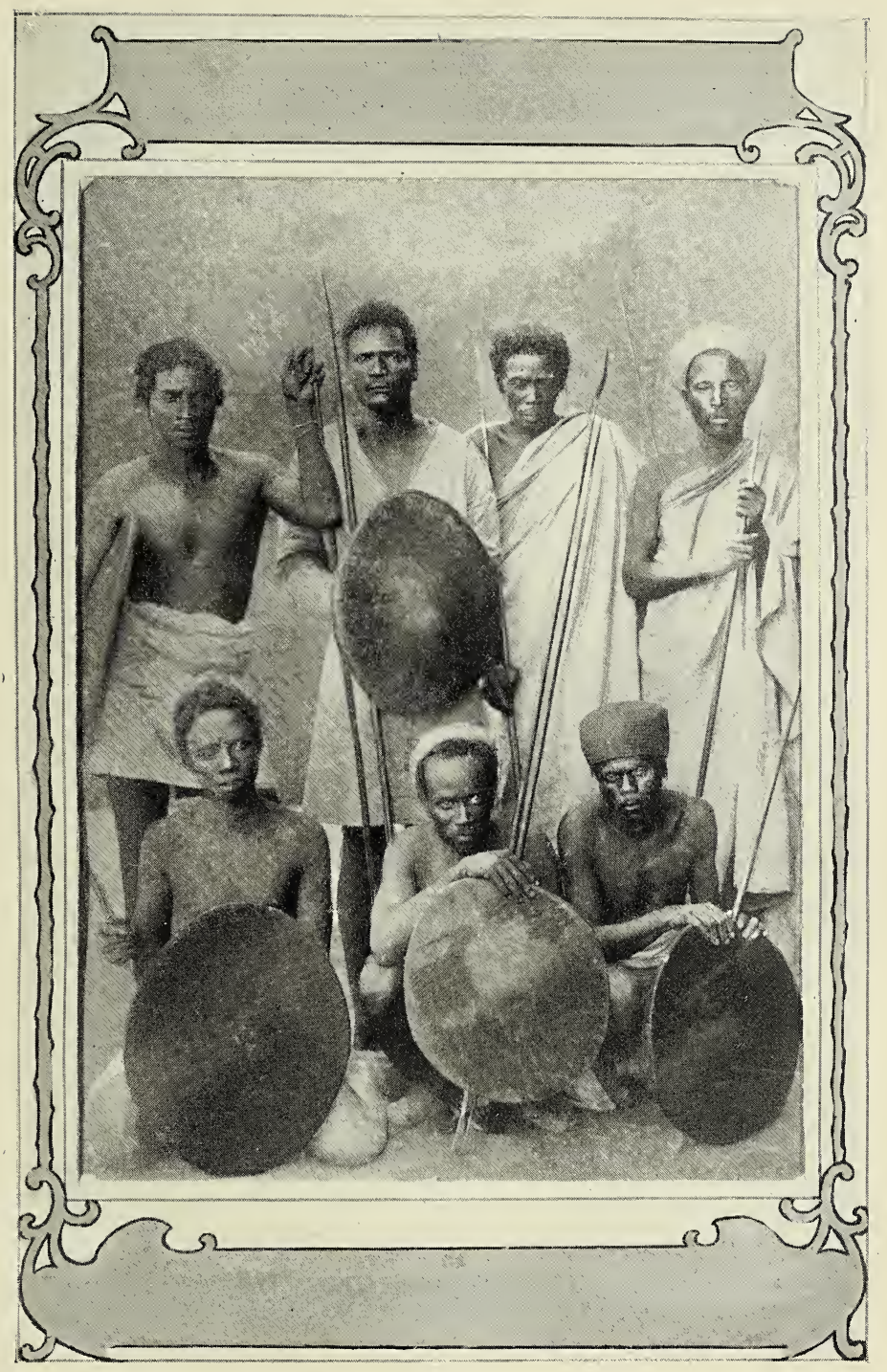

HEATHEN MALAGASY. 



\section{Heathen Habits}

slaves were all at his mercy, and were practically his concubines, or those of his sons, or both. As the children of the slaves, whether married or single, were all the property of the masters, the more the slave children increased, the richer theybecame; thus a premium was put upon immorality, as a slave woman who had children was better treated than one who had not.

As barren women were hated and despised among the Hovas, and not always well treated, a young woman who had a child could choose her husband from among many suitors. As a consequence of this, Hova parents urged and encouraged their daughters to immorality, and young men were allowed to live and associate with them in the hope of their having children.

When a slave owner left home in former times on a raiding or a trading expedition, a female slave was sent along with him as his cook or housekeeper, ostensibly to attend on him and look after his wants; but the euphemistic name given to her showed why she was sent. If this could not be done, owing to the fewness of the female slaves or for some other reason, he and his wife gave each other the saodrànto, a temporary divorce-literally, the divorce of trade-and so each was free to take up with whom they pleased during the period of separation.

Such are some of the milder phases of heathenism; and yet some people ask, Why disturb the heathen in their happy, blissful life? The Hovas were dying out when Christianity found them, and saved them as a people. Like the Roman empire, when Christianity was introduced into it they were rotting away, and would have soon ceased to exist.

While doing all I could in the way of teaching and preaching, I was hard at work on the language. Owing 


\section{Breaking up the Fallow Ground}

to my own bad health and my wife's serious illness I was unable to give more than some six months to this subject before my first examination fell due. I passed it, but only by the skin of my teeth. I read my first address in the vernacular three months after I began the study of the language; but I have often wondered how much of it was understood by the peopleI am afraid very little. It is not till one can think in a language, and is able to look at things in some measure as the natives do, that one can really reach them and touch their hearts to any profit.

Our late principal used to hint to his students that many a young missionary spoke to the natives in an unknown tongue without the aid of inspiration! $\mathrm{He}$ was right. We have had a few curious examples in Madagascar of the mistakes made by young missionaries in their first attempts at preaching in a new language. A devoted missionary had selected the text, 'Lord, Lord, open to us!' which in Malagasy is Tompo, Tompo, vohày izahày! but instead of this he read and repeated, Tompo, Tompo, voày izahày! which was 'Lord, Lord, we are calf crocodiles!' Our hostess, during our first fortnight in Antanànarìvo, meeting her native nurse in the lobby, by a slip of the tongue gravely asked her if she had cooked, instead of asking if she had bathed the baby! The look of horror on the face of the nurse, and her 'What, madam ?' caused our hostess to realize what a slip she had made.

The Malagasy were too polite to laugh at one, even when the grossest mistakes made by a young missionary in phrase, grammar, or pronunciation greatly tempted the risibility of the hearer. The Hovas were a very polite people; they would not pass you on a country road without asking your permission to do so. They 


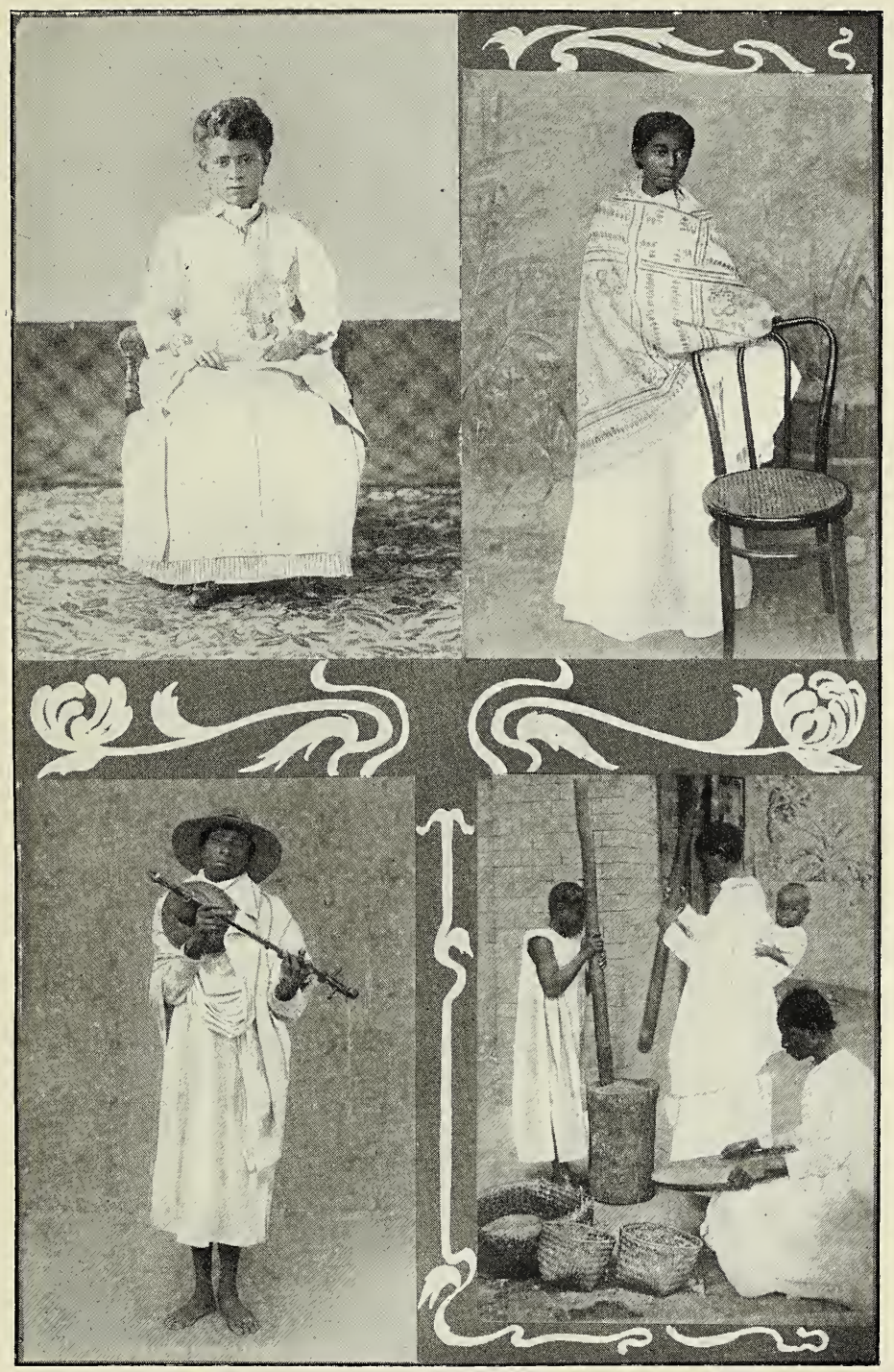

MALAGASY TYPES.

A HOVA PRINCESS.

A MINSTREL.
A HOVA CHRISTIAN.

MALAGASY POUNDING RICE. 

received reproof gracefully, and I have been thanked for giving a man a very severe scolding.

Probably bad proof-reading was responsible for many mistakes in former editions of the Bible, especially in the Old Testament. For example : in Gen. xviii. 4, instead of Abraham saying to the angels, 'Let a little water, I pray you, be fetched, and wash your feet,' the father of the faithful was made to say, 'Wait until I steal a little water,' \&c. The Bible records that the builders of the Tower of Babel said, the one to the other, 'Go to, let us make bricks, and burn them thoroughly,' but the word boriky (Fr. bourrique), ' ass,' was used in the old editions of the Bible in mistake for biriky (Eng. 'brick'); and so they were made to say, 'Go to, let us make asses, and burn them thoroughly!'

In the story of Samuel we are told that, while a lad, ' His mother made him a little coat, and brought it to him from year to year' (r Sam. ii. 19). The Malagasy had no such garment, and hence no name for it. The name ànabỳ (Fr. un habit), which was used for a coat, was the name for the English soldiers' old coats or tunics with the short tails, two hundred of which were given by the British government annually for many years to Radàma I, along with the same number of old flintlocks, to clothe and arm his guards, in return for his agreeing to stop the slave trade. Samuel's mother was therefore said to have made her son an ànabỳ, a coat with short tails, and taken it to him year by year. These were all slight blemishes, however, when compared with the glorious truths the Bible made known to the Malagasy people-truths that were in every sense of the word revelations, transforming their lives.

A few weeks after we were settled at Fìhàonana Razàka came to me bringing a deacon, who had been 


\section{Breaking up the Fallow Ground}

sent from one of the distant villages to seek my advice under the following circumstances: the local preacher of the village church from which the deacon came had fallen into sin, and was living with a young woman, one of the singers, notwithstanding that he was a married man. The church came to know of his conduct, and were for excommunicating him at once; but they had to face this difficulty: the church possessed no Bible of its own, and that which had been used from the first belonged to this man. Now, if they excommunicated him, naturally he would take his Bible with him, leaving the church without one; and yet they could not think of allowing him to remain as a preacher. What were they to do? I soon put matters right by giving the deacon a pulpit Bible for the church, which should belong to it and to no one man, and telling them to suspend the man from church fellowship at once.

Shortly after this deacon visited me I was told, on good authority of a chief down towards the north-west coast, who having heard that the queen, the prime minister and the officers of the palace had become Christians, and that the great majority of the people in Imèrina had followed their example, thought he and his people ought to go and do likewise. He convened all his subjects, of whom I understand there was a goodly number; and, having secured the services of a man from the capital, who professed to be a Christian pastor or preacher with authority to baptize converts, he had the whole of his clansmen and slaves baptized there and then. He then addressed them to this effect: 'Now you are all baptized Christians, see that you conduct yourselves in a proper manner; for if I hear of any of you doing wrong, I shall certainly punish you very severely. For the first offence I shall have 


\section{Church Difficulties}

you beaten, and for the second I shall have your heads cut off!'

I was assured that this had a most wonderful and beneficial effect for a time on that part of the country, but of course it did not last. Men cannot be forced into religion, or coerced into Christianity - and their religion would not be worth having if they could. The condition to-day of those districts in which coercion was practised or permitted by the so-called 'Palace Church Evangelists' and other government officials, from mistaken motives, is a sad enough example of that.

One of my pastors came to me during my first year in the district to ask what was to be done in the following case: A man had been baptized after having attended the classes for instruction in the " fundamentals of the faith' for the appointed time. His character was good, he seemed to understand what he had learned, and was believed to be a Christian man. Some time after his baptism, as he wished to join the church, he attended the communicants' class for further instruction, and at the end of the appointed period, there being nothing against the man, but everything in his favour, the members were about to receive him into the church; but then they were met, as they thought, by a great difficulty. His wife did not wish to join the church, was not even baptized, and had no wish to be. Their problem was this-could they receive the man alone, and so, in a sense, separate husband and wife? There was another analogous case, where the wife wished to join the church, but not the husband. 'May we admit the husband without his wife, or the wife without her husband?' they asked; or 'Must we tell the husband that he must wait for his wife, and the wife for her husband?' Of course I replied that they were not to 


\section{Breaking up the Fallow Ground}

keep a man from the Communion because of his wife, or a woman because of her husband.

On my first visit to Ankàzobè, a large village about thirty miles to the north of Fìhàonana, while conducting the Communion Service I saw three small boys among the communicants, and asked who they were, and what they wanted. I was informed that they were church members, and I afterwards discovered that one of them was the son of a local preacher. I told the church that it was not the custom to take such young children into membership, as they could not understand what the ordinance meant. After the service I had a long talk with the church as to who ought, and who ought not, to be received as members with regard to years, knowledge and character.

While occasional irregularities appeared in different places, there were not half so many as I expected. As a whole the churches were in a marvellous condition, considering the scanty opportunities they had enjoyed of being instructed in the things that pertain to the Kingdom of God. If they made mistakes, which of course sometimes happened, it was almost always solely from want of knowledge. If they knew what ought to be done, they generally did it. I fancy this is more than can be said of some church members at home. I may also add that grave mistakes were few-so few, indeed, that one was reminded of the words : 'They shall be all taught of God.'

If anything of a really difficult nature cropped up they usually sent on to Fìhàonana to ask my advice; and before our settlement there they sought guidance from the capital. Repeatedly I had to crush the idea that I was the head of the churches, and that what I said must be regarded as law. I always tried to 


\section{Gleams and Glimpses}

impress upon them that I was in no sense a supreme authority, but only one of their teachers, and that the assembled pastors of the district should settle the questions which arose, e.g. whether a church was needed or not, and what was the best site on which to build. For they knew the district and people and their needs better than I could, and were quite capable of deciding such matters. Then again, I thought it wise to leave everything the Malagasy could do for themselves in their own hands, that they might learn self-reliance.

Missionaries for the most part should merely stand behind the scenes and prompt their people in the right direction, and then, as far as possible, allow them to act for themselves. It is essential to the best interests of Christianity that the assembled pastors of the churches in any district should decide how many churches should be formed in that district; otherwise every tiny village might set up a church, although it had only six huts, and whenever one petty chief fell out with another each would cause his people to build a church in his own village, of which he would probably be appointed pastor, even if there were but twenty people, and half of these twenty children. This sort of thing was done repeatedly in certain districts.

I must content myself with sketching the broadest outlines of my work, giving glimpses of certain parts merely, the general facts connected with the whole; for there were many matters that occupied my time and attention during those earlier years which cannot be embodied in a short account like this.

The people were most grateful for all I could do for them medically, although they entertained most absurd notions, and had absolute faith in my power to cure all 


\section{Breaking up the Fallow Ground}

little ills that flesh is heir to. I was often at my wits' end, and did not know what means to use-a state of mind which generally ended in making an experiment upon them, and giving what I hoped would do them good. When they returned to tell me that they were cured, and thank me for it, I often wondered whether it was the medicine, or their faith, or old dame Nature herself that had cured them-and if she would not have done it, even if they had taken no medicine at all.

I was perplexed for some time, by their always asking me, when medicine was given, if they ought to fast, until I discovered that the old idol priests and sorcerers were doctors, of a kind, and that their general prescription (and I am inclined to think their best) was fasting, especially from pork. The Malagasy often made themselves ill by overeating. It seemed as if the people reasoned somewhat in this way: If the old idol-keepers, priests, and sorcerers could cure some diseases, the teachers of the true religion must be able to cure all. Be that as it may, a small service to the body gave great influence over the minds of these people.

The vast majority suffer from the effects of poisoned blood, due to hereditary taint or vicious habits. As a consequence, hundreds of innocent infants perish; precious lives ebb away before their time; disease is fostered; and deterioration-physical, mental, and moral-is spread throughout the entire community.

Bookselling took up much time also, until a colporteur was found. I sold about $£_{3}$ o worth of books during our first year at Fihàonana ; but to the Malagasy that really represented what $£ \mathrm{I} 5 \mathrm{O}$ does to us.

With regard to the state of the churches, as I found them in I87 I, all I can say is, that if not quite all we 


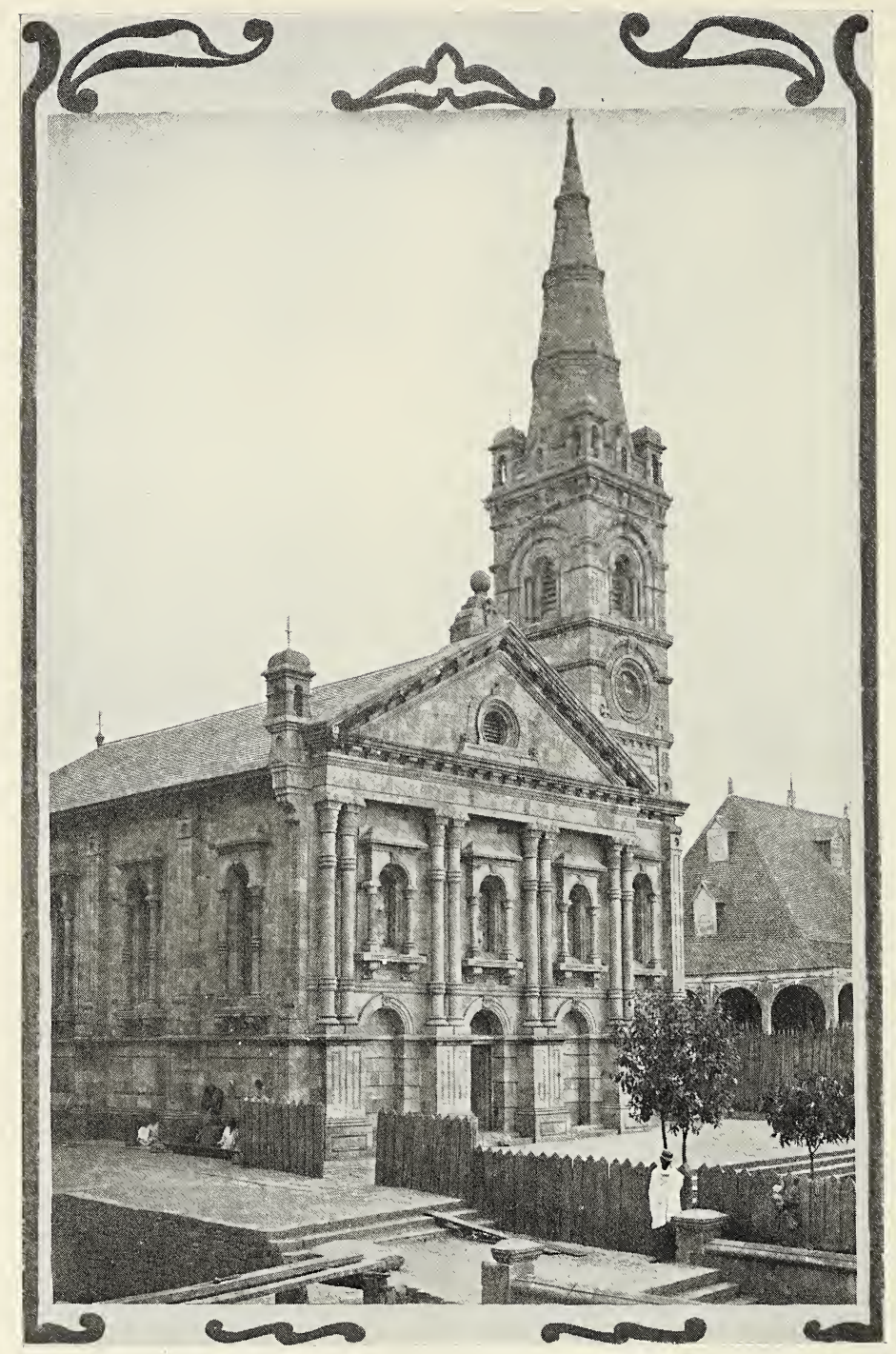

THE PALACE CHURCH, ANTANANARIVO. 


\section{Worthy Pastors}

could have wished them to be, they were a great deal better than we had any right under the circumstances to expect. While others had to tell of multitudes rushing to baptism and many to the Lord's Table, in an altogether unfit state, I had nothing of the kind to complain of. On the whole things were done decently and in order in Vònizòngo. This was in a great measure, if not entirely, due to the fact that there was such a man as Razàka superintending the district and directing the other pastors. I attribute, under God, the very satisfactory state of the churches found in Vònizòngo, when compared with most other districts, to the wise conduct of Razàka, and Ràinisòa, the chief pastor of the Fìerènana district, and to the kind of men whom, as a rule, they led the churches to choose for pastors and preachers. The pastors as a body, although of necessity they did not possess much knowledge-in fact there were some few of them who could not even read-possessed a good deal of common sense. These men had done, and were then doing, noble work.

Although I have heard much about it, I never saw an instance of people being thrashed to church. I did see, in $188_{3}$, in another district, people brought to church by Malagasy policemen, by order of the 'Palace Church Evangelist,' who did just as he liked, ruled the district with a rod of iron, and ruined it-so that to-day it is only the shadow of what it ought to have been. We had no such doings in Vònizòngo.

I heard of one little Andriandàhy-village squire or squireen-who had been accused of thrashing his people to church. I sent for him and all connected with the case, and went into the whole affair, and found, after hours of investigation, that it amounted to nothing more than this: he met a slave of his going to another church, 


\section{Breaking up the Fallow Ground}

seized him by the arm, and perhaps twisted him round, and told him he ought to attend the same church as himself. The slave informed the pastors of his church what had happened; and the two pastors, not being on the best of terms with his master, tried to make a case against him. I believe my summoning all parties to meet me did good; for the report of what I had done soon spread, and also of what I had said on the subject of masters compelling their people to attend church. This was the only case I ever heard of in Vònizòngo, and I am quite certain that little, if anything, of that kind was done in our district.

One reason of this was that the majority of the people themselves were so anxious to attend the House of God (many of them no doubt from mistaken notions) that nothing of the kind was needed. But even if many of them had been made to attend church by the head-man of the village, instead of being left in the village to steal the goods of those who did go, or to commit worse crimes, I confess that I cannot see it to be so terrible a charge after all. At the same time, I should most certainly tell the head-men to take no such course. It was a phase of 'compulsory education,' as the church was then the only means of education, and the Malagasy were only overgrown children. In some districts the 'Palace Church Evangelists' fined those who did not attend church; but even that was only history repeating itself. For in England, in the days of 'Good Queen Bess,' a man was fined a shilling if he did not attend the parish church once a month.

The state of things I found in Vònizòngo astonished me not a little. What the people chiefly needed was to be taught and guided; and they were most anxious to follow that which was right. Of course many things 


\section{Thoughtless Expectations}

were done among them which we did not like. But as knowledge was imparted most of the objectionable things disappeared like morning mists before the rising sun. But the piety of the people proved to be more substantial than the 'morning cloud and the early dew that passeth away.' Central Madagascar had been roused by the power of God's grace from the sleep of ages. Some regarded our work with suspicion, and, because all our converts did not at once equal the Christians of lands that have had the Gospel for centuries, they were almost prepared to ascribe it to mere political excitement or surface-work.

More seems to be expected of converts from heathenism than from home converts, and even than from ordinary Christians, when there certainly ought to be much less. No time is allowed for growth in grace, which there certainly ought to be, as it is generally found, I think, that there is as much human nature in most of them as there is in other people-if not more. Heathen habits of a lifetime and heathen superstitions are deeply rooted in their natures, far too deeply to be very easily eradicated. 'It is very strange indeed that it should not be taken for granted that many native Christians, even when truly converted, are, like so many Christians at home, cold-hearted, inconsistent and vulnerable to the shafts of temptation.'

We cannot expect the subjects of 'the obscene empires of Mammon and Belial ' to take any interest in Christian missions, or do anything except scorn missionaries, their work, and their converts.

Unless people have a heart interest in religious work, they are likely to make the most of the shortcomings of native Christians-as a sort of self-justificationand to disparage the work of the modern missionary 
122 Breaking up the Fallow Ground

accordingly. They would not dare to disparage the work of the Apostle Paul, because history has vindicated it; but they choose to forget what 'unsatisfactory' people many of Paul's converts in Corinth and Galatia were. 


\section{CHAPTER VI}

\section{EARLY EXPERIENCES}

'Truth springeth out of the earth; and righteousness hath looked down from heaven.'-PSALM lxxxv. Ir.

OuR enforced sojourn in the capital for the first four months of the year 1872 , while in some respects a privation, afforded me more time to work at the language. I was also able, while there, to buy most of the wood for our future manse, to get brick-moulds, and agree with a master bricklayer for building it. Many other things were also arranged which it would have been difficult to negotiate from Fìhàonana.

We started back for Vònizòngo in May, and as we thought it would be easier for my wife and the baby to go as far as possible-about halfway-by canoe (along with some friends who were travelling west for a holiday), we adopted this course; but with such results to both, from exposure on the water to the unclouded sun for six hours, that we never repeated the experiment. I had sent the wood for the manse down the river by canoe, and wished to see where it was stored.

At the end of the voyage, we had our first and last real difficulty with the palanquin-bearers during thirty years. After eating all I had provided for them, they coolly told me that as their companions (who were to carry our friends to their destination-a few miles from where we landed) were not going on to Vònizòngo, they 
declined to keep to their contract and take us there, and demanded prepayment for carrying the empty palanquins from Antanànarivo. As $\mathrm{I}$ refused to accede to their preposterous demands, they took advantage of my absence when seeing after my wood, to set off on their return to the capital, carrying off my palanquin, which they had, however, to return a fortnight later with a humble apology. The leader of this conspiracy I had to encounter and conquer, on our way to the coast in I 879, after which we were good friends.

Fortunately I had sent to Fihàonana for eight men to meet us, in case porters enough from the capital, willing to go to Vònizòngo, were not to be had. These men had to carry my wife, two children, and the nurse twenty miles. I had to tramp on foot. Four men carried our eldest child and the nurse, took them across the streams and swamps, and then returned for me. Our good friend Mr. Cameron, who was making a trip to Vònizòngo in the interests of geography to take bearings for a map of Madagascar, kindly let my wife have two of his eight bearers, and thus they reached Fihàonana by sunset, but we did not arrive until nearly ten o'clock; still our reception was well worth all the trouble we had experienced.

On the arrival of my wife and Mr. Cameron at Fihàonana, they told of the plight in which we had been left. Razàka and the young chief called the men of the village together, and told them how we were placed, and they volunteered to come and meet us, with a supply of torches made of dried grass to light them on their way. We saw the flaring light on the hills miles in front of us, and could not understand what the moving mass of fire marching towards us meant until we came within shouting distance. We were carried into Fìhòana in right 


\section{Manse-building}

royal style, amid the blaze of torches and the shoutings of the people. The whole village had turned out, and the shouting, hurrahing, and joyous yelling, with the singing and hand-clapping of the women and children with which we were welcomed, was a thing never to be forgotten.

A fine site for the manse was secured on the rising ground to the east of the village of Fihàonana. A very large village had formerly stood there, and so there was a fosse and embankment round it. The chief and his brother made it over to me, declining any rent. I told them, however, that there must be rent, however nominal, in order that I might make an agreement with the government for it on behalf of the Society, and then they agreed to the nominal sum of four shillings a year. When the agreement came to be signed by the then Hova foreign secretary-a 'haughty Hova,' thinly veneered with a profession of Christianity-he took the chiefs to task for allowing me to have such a site so ridiculously cheap. This led to an animated interchange of ideas between him and me. Ultimately it was agreed that the ground-rent should be twelve shillings a year. For that small sum an enclosed site of five acres was secured for forty years to the London Missionary Society. There I built a manse, a large school-house, and a smaller one for girls. Afterwards another dwelling-house and school were erected there. But, alas! in 1897 all that remained of these buildings were seized by the French, and no compensation has ever been paid for them.

With the moulds brought from the capital, I soon taught the people how to make sun-dried bricks. The chiefs and pastors of the district offered to have all the bricks required made for nothing; but having strong views on the subject of slavery, I asked them: 'Will 


\section{6}

Early Experiences

you hire and pay men to make them or will you simply make your slaves do it ?' Of course they said they would set their slaves to make the bricks, so I felt I must decline their generous offer. At this they seemed astonished and hurt.

My action in this matter was a mistake. I ought to have accepted their proffered aid, and then given their slaves the money afterwards paid for making the bricks, in the form of 'presents' wherewith to buy salt and beef, to fit them for their extra work. But we have all to buy our experience.

One morning I sent for the men who professed to be equal to making the bricks I required. 'Now,' I said, 'I want 200,000 bricks (made); how much per thousand will you make them for?'

'Well,' they said, 'you are a good man who has left his home, relatives, and native land to come to teach us.'

'Yes, yes,' I said, 'that's all right, but never mind those trifles at present, we can discuss them at any time, they will keep, let's discuss the bricks now. How much will you make them for per thousand ?'

'Well,' they answered, 'as you are that good man we mentioned, we will make them for you for four shillings a thousand.' That would have been $\$ 200=£ 40$, but then equal to $£ 200$ to them.

'Thanks,' I said, 'I am much obliged, but I can only give sixpence per thousand.'

'Only sixpence a thousand,' they said, with wellsimulated astonishment.

' Yes,' I replied.

'We won't make them for that,' they said.

'Well,' I answered, 'I think you had better go home and reconsider your demand for four shillings a thousand; for you know very well that such wages are simply 


\section{Builder's Troubles}

ridiculous, and when you have come to your senses, and are prepared to be reasonable, come back and we will talk the matter over.'

They went away, but returned the following week to offer to make the bricks for two shillings and sixpence a thousand.

'No,' I said, 'sixpence per thousand.'

Away they went for another week, and by that time they had come down to one shilling and sixpence per thousand.

'No,' I replied again, 'sixpence per thousand'; but I added: 'How foolish all this is on your part; you keep on haggling, first saying four shillings per thousand, then two shillings and sixpence, and now one shilling and sixpence. Now, as I don't wish to be hard on you, and I want this haggling brought to an end, and the work begun, if you come down one sixpence I will go up one.'

'That's it, sir,' they said, and so we struck a bargain for one shilling a thousand.

I expected to have to pay tenpence or one shilling a thousand-although, if I could have held out, I might have got them for my first offer-but if I had offered one shilling I might have had to go up to one shilling and sixpence. As it is only during the dry season that bricks can be made and houses built, I had to raise my offer to get them to set to work.

But perhaps some good sensitive soul may be thinking, "The interests of the Society are all very well, but what about the interests of the poor natives?' Well, my friend, you may with confidence leave the interests of the natives in the hands of their best friends, the missionaries, as few of them are likely to take a mean advantage of their charge. But even if they were, with 
few exceptions, most natives I have met with may be left to look after their own interests; they are quite equal to that. But to show I was taking no mean advantage of my people I may state that, up to the time of our settlement at Fihàonana and for long after, a porter had to carry eighty pounds of salt from Andriba to Fihàonana-a three days' journey-for threepence! My brick-makers, by working morning and forenoon, could easily make two shillings a week.

They could live and keep a wife and family on sixpence a week in those happy days. Rice in the husk, in the harvest season-when most people who had not large rice-fields of their own laid in a stock of rice for the year-could be bought for a penny a measure in Vònizòngo, and two measures would serve a fairly large family for a week. Since 1896 rice has never been under one shilling a measure. It has been as high even as three shillings in some parts. Starvation was formerly almost unknown in Madagascar. The men who made my bricks had very few expenses except for food; for their tailor's, draper's, hatter's, shoemaker's and upholsterer's bills were very light!

The master bricklayer failed us. He sent some professed bricklayers in his place, but if they were bricklayers they were surely the poorest who ever laid bricks. They were either ignorant of the use of the plumb-rule, or were too lazy, or in too great a hurry to get the walls rushed up to use it, with the result that they built the walls off the plumb. In my anxiety to overtake the work I foolishly kept on all my classes and district duties. I ought to have stood beside these men and seen every brick laid; but I regarded this as a sheer waste of time, with so much teaching, preaching, and other mission work to be done. Those who gave up 


\section{Huts and Houses}

all their district work for months, while their houses were being built, acted wisely. The result was that I would often return home, after an exhausting day, to find that the walls had been run up several inches off the plumb.

To have our bedrooms as far from the ground as possible, for health's sake, the manse was built doublestoried, as is most desirable in a malarious district. It was the first two-storied house built in that part of the island, and as its walls rose they caused much talk among the people. At last Razàka came to ask me if I quite understood what I was doing. There had never been such a high house built there, and the people were afraid it might fall or be blown down by the frequent hurricanes. I assured him that I quite understood what I was about, and that there was no fear of the house falling or being blown down. It stood all the hurricanes we had, some of them very severe, and might have lasted for another thirty years, but for its being burnt down in 1897.

On the coasts of Madagascar, and for about half or two-thirds of the way up to Antanànarivo, the native huts are built of a framework of poles and bamboo, filled in with bulrushes, and roofed with the leaves of the so-called 'traveller's tree,' a kind of palm. In Central Madagascar the huts are built of layers of mud, one layer being allowed to dry before the next is laid on. The houses are built of sun-dried brick. In many cases now-especially in the capital-the outside walls are of burnt, and the inside of sun-dried brick. The roofs were thatched with flags from the swamps, or with rank grass from the moors or the stream sides. All houses in the capital have now to be tiled for fear of fire. We built our house of sun-dried brick. There is no frost 
in Madagascar, so well-built houses, with verandah round, if the roof is kept in repair and the outside walls are replastered from time to time, will stand for fifty years.

We plastered the walls of our houses outside and in with mud, mixed with a substance remotely related to 'attar of roses'! Then we covered them with cheap wall-paper, glazed the windows, and so made nice, comfortable, homelike houses. By far the nicest, most convenient, and most comfortable house we ever had in Madagascar was the manse built at Fihàonana, which cost only $£ 25^{\circ}$, and $£ 40$ of that even went for carriage of material. It was found fault with in later years by a young, up-to-date missionary because it was not aesthetic enough! In those days we did not trouble ourselves about aesthetics, we thought more of health and convenience. The idea of a missionary set down among a heathen people concerning himself about aesthetics is quite refreshing, almost as refreshing as the remark of the man who said district itinerating could never be properly done until there were railways, and so gave up attempting to do it!

All government work-and much for members of the government and upper officers-was formerly done in Madagascar by a kind of feudal service called fanompoina. As it was often very severe, it was heartily hated, and was generally got through as quickly as possible. Thus a tendency to scamp work became almost second nature with most workmen, unless strictly watched, even when working for wages. I got some carpenters who were most unsatisfactory. Not only was their work scamped, but wood and tools disappeared. I resolved to catch them red-handed before bringing a charge against them. One day I suddenly appeared on the scene, when they had no suspicion that 
I was in the neighbourhood, and found them hanging the room doors. They had made the screw-holes for fixing the hinges, with a gimlet so large that they could push the screws in with their thumbs! These doors, made of hard and heavy wood, must have proved awkward for any one on whom they might fall.

When I appeared on the scene the screw-driver was seized, and a pretence was made of sending the screws home, which, of course, seemed very hard to do. When they had finished I said: 'Yes, that is very fine, now give me the screw-driver.' I then turned the screws and picked them out with my fingers. 'Now,' I said, 'you have been cheating me for weeks, and scamping your work. I can't stand any more of this. Go home. I give you an hour in which to leave the village, and if you have not left by that time I shall write to the prime minister, tell him the whole story, and leave him to deal with you. Apply to him for the wages due to you, and when he applies to me I will send the money. I hope this will prove a warning to you, and teach you not to cheat or scamp your work for the future, but to do honest work for honest wages.'

They left the village within half an hour, and no application was ever made to me for arrears of wages. Of course they spread false reports about me and my treatment of workmen. This led to a long delay before I could get carpenters to come from the capital to work for me; but, at last, I was so fortunate as to secure a little man who had something almost akin to genius for carpentry. He worked for me at various times for twenty-eight years. My troubles with these men were thus a blessing in disguise. Without them I should never have found my born carpenter Andriantàvy. $\mathrm{He}$ was one of the pastors of a very small church in the 
neighbourhood of the capital, and a most trustworthy man.

The Sabbath services were always the most helpful, whether at Fihàonana or out in the district, as one had a sense of freedom and the feeling that nothing was being neglected in order that they might be held.

The conduct of my bricklayers, and the want of carpenters for several weeks, ran me far too near the end of the dry season with my manse unroofed. Had the rains come on while it was roofless, my ceilings would have been brought down and the walls greatly damaged. As it was, we only escaped by two hours; for the thatching was finished at four o'clock, and at six we had the first rains of the season. In order to accomplish this, however, I had to hire forty men, and give up all other work to superintend them and see that the thatching was properly carried through under my own eye.

Church and manse building, even in the mission field, is very prosaic work, with little of the rainbow of romance about it, but it has to be done. In our case it was a most serious undertaking, for we were roo miles from the 'forest,' and all the wood had to be brought the whole distance, with the exception of some twenty miles, on the shoulders of men from there. The building of our manse was perhaps a more serious affair than it ought to have been. In addition to all the difficulties of the situation, I, in common with most missionaries, knew nothing about house-building. I had never had to do with the building of a house in my life, except a rabbit-hutch, when I was a lad, to which an old teachest lent itself. I knew a little about some branches of practical mechanics. This was of more use to me than much other knowledge to acquire which I had spent a good deal of time, and not a little 'midnight 
oil'; but of house-building I was wholly ignorant. In the circumstances I had just to buckle to and make the best of things. If a man only does this he will be astonished to find what he may accomplish under God's blessing.

I have thus dwelt a little on some of the kinds of work which it falls to a missionary opening a new station to carry out, to show, if that be still required, that, as Dr. Livingstone says: 'A missionary is not merely a dumpy man with a Bible under his arm,' as many good people suppose him to be. The true missionary is a many-sided man, who must be prepared, and will be, to be anything or nothing that will help forward his work, without any fear of its being beneath his dignity. My experience fully bears out Dr. Livingstone's statement that: 'If young missionaries for Africa would spend one-half the time they have to spend over Latin verbs, in learning how to make a wheelbarrow, or mend a waggon, it would be infinitely more useful to them afterwards.' At the same time, it is well to keep in mind, that what may be very suitable for one part of the mission field may not be so for another. A university training would be the best preparation for some fields. If his missionary enthusiasm will not carry a young man through a university course, it cannot be of the right kind, and would not carry him far in the mission field.

There is little that is sentimental or romantic about the erection of mission buildings, and yet they have a decided value of their own in showing the natives among whom he is destined to labour, that the 'white teacher' has come to stay, and that he means work. This most useful, necessary, and trying work is, strange to say, often one of the most thankless tasks that a 
missionary can take in hand. A man may be thankful if he gets off without censure for 'erecting so many buildings at his station,' even when he has found among his personal friends most of the money for their erection. From some fellow labourers he may incur blame for having so much to do with ' mere secular affairs.' Nothing which ought to be done should be regarded as merely secular, and least of all where it is to be a means of extending Christianity. 'Christianity touches everything, or it touches nothing.' The man who is not prepared to be anything and everything-a hewer of wood or a drawer of water-or who has not got above regarding this or that kind of work as being beneath his 'abilities,' 'culture ' or 'dignity' to take part in or do, ought not to go to the mission field. 'When St. Boniface landed in Britain he came with the Gospel in one hand and a carpenter's rule in the other; and from England he afterwards passed over into Germany, carrying thither the art of building.' It may be easy for one class of workers to look askance at another, because the circumstances of the latter may compel them for a time to be a good deal ' among bricks and mortar.' It is, however, quite possible to serve God and His cause even in such lowly work. In saying these things I am fighting no phantoms.

Of course things have altered, and have been very much improved in some respects during the past quarter of a century, even to the country missionary. In our time he had not only to be physician and dentist to his own family, but also to some ro,ooo people. He was not only preacher, teacher, and guide to the churches and people, but amateur architect, builder, bookseller, and general adviser to his district on almost all subjects; in fact, director of practically everything, and for some 
years actually judge of the divorce court! Indeed there fell to him too much work of all kinds, much of which he ought not to have had to do ; but then there was no one else to do it, and he had to take it up and do his best. Work under these circumstances in country districts, in these early days at least, was the most laborious, worrying, and wearying I have ever known. It was never finished, but its very difficulties and drawbacks, in my opinion, made it all the more elevated, enviable, and honourable.

I have mentioned the divorce court, or rather, the cases of divorce which came before our monthly church meetings, and on which we had to pronounce judgement. It was a most disagreeable duty which we were thus compelled to take up. There was one satisfaction about it: our judgements were seldom disputed or departed from. They were almost always loyally carried out. During the earlier years of our first term of service we seldom had three church meetings in succession without having a case of divorce to settle. But such has been the progress even in that direction, that I had only one bad case to deal with during the past fifteen years.

One day one of the best and most godly of our native pastors came to me in great sorrow. His daughter had been married-against her father's will, I think-for some years to a petty chief of some means, but no character. He had tired of her, or had seen some one else that he fancied, and so, to get rid of her, he brought a charge of infidelity against her. She denied the charge most vehemently, but as I was then in charge of West Vònizòngo, in addition to my own district, her father came and asked me if I would, as a personal favour to him, go into the case privately first, and see where the truth lay. I agreed to do so, and on the day appointed he, his daughter, her husband, their relations, and a few 
friends came to the manse, and we went into the case. I had little difficulty in seeing almost from the first that it was a trumped-up charge. Few Malagasy can stand cross-examination; they soon contradict themselves. After I had quite satisfied myself that the charge was false, I took the husband and wife into my study to have a private expostulation with him.

'Now,' I said, 'I am quite convinced that you are bringing a false charge against your wife.'

'Indeed he is,' she said; 'I would sooner die than disgrace my father and friends by such conduct.'

'It is very easy for you,' I added to the husband, 'to bear false witness against your wife, and so deceive us by lies; but how will it be when you have to face those lies at the judgement-seat of God ?'

He was startled for a moment, but soon recovered himself, and stuck to his charge. When we rejoined the others, I said, 'I feel quite satisfied that this man is bringing a false charge against his wife, but, as he holds to it, we must probe the affair to the bottom.' I asked him if he had any witnesses, and he named some. I caused them to be summoned. I again turned to him and asked, "Who is the other culprit, do you know him?' He answered that he did not, that he was a petty chief from the north. I asked, 'Would you know him again if you saw him ?' He replied that he would not. 'That,' I said, 'is rather unfortunate for you, because you must find him and bring him before me, as we must get to the bottom of this business.' He replied that he was not going to trouble himself hunting for him or bringing him before me. We might seek him if we liked, but he would not. ' But,' I said, 'the matter cannot be settled in that way, it is far too serious. You know that, for the time being, we are "father and 


\section{Falsehoods and Facts}

mother" to both districts of Vònizòngo.' He replied that he did. 'Then,' I said, 'in virtue of that, your wife is our daughter, and as we believe her to be quite innocent of the charges you bring against her, we mean to stand by her and have her proved innocent. I give you a month to seek for that petty chief, and bring him before me; but if you fail, I shall write to the prime minister to ask him, as a personal favour, for a sergeant and six soldiers to go with you to help you to find that man; because if he is still alive and in the island he must be found and brought before me.'

The man looked at me with astonishment and terror, and if he had been a European he would have turned deathly pale; but, as it was, his colour became something between a green and an ashy grey hue, and when he had found his tongue it was to confess that the whole charge was false!

The thought of meeting his falsehoods at the judgementseat of God had no terrors for him (although, poor fellow, he was nearer eternity than he or any of us thought, for he died within three months); but to face the prime minister was too serious a matter. That was an unusually serious case, but it will help to give some idea of the work which we had to undertake.

As far as is known none of the tribes in Madagascar were ever cannibals. The Hovas in particular would have been the last to dream of homan' olona, cannibalism in any form. They regard it as the most hideous and revolting practice conceivable. Their great respect for the dead, the care they take of the corpse, and the fine family tombs they build, all point in the opposite direction. The horrors of cannibalism, as known in New Guinea and on the Congo, were utterly unknown in Madagascar. But this, notwithstanding, all the tribes 
in the island--including the Hovas, the ablest and most advanced in civilization of them all, and until the advent of the French the dominant tribe-had sunk to a most revolting state of moral degradation. This is still the condition of the majority of the other tribes. Most of the crimes in that long black list, which the Apostle Paul brings against the Corinthians, might have been brought against the tribes in Madagascar, even against the Hovas, with the sentence, 'Such were some of you.' So that if missionaries had done nothing more for the Malagasy than raise some of those tribes-the Hovas in particular - to a platform of common decency, and inspire them with the desire for higher and better things than they had ever known, it was a work well worth doing. But the Gospel has done much more for the Hovas than this. It has made thousands of them 'new creatures in Christ Jesus.'

When Christianity was first introduced to Madagascar, and for many years after, the Malagasy might have been said to have been perfectly destitute of spiritual instincts, and hence the reception by them of spiritual mysteries, not to say spiritual truth, was almost impossible. Their moral natures, their spiritual instincts and conscience had almost to be created or recreated. The progress which Christianity made during the fifteen years that the first missionaries were among them, and as the result of their labours, was truly astonishing. Persecution and martyrdom only rooted the faith more firmly in the hearts of the faithful few, and spread it among others. Hundreds were thus led to inquire about that ' faith ' for which their fellow countrymen and women were prepared to die rather than renounce. Thus by the time the idols were burned in 1869 , and the queen, prime minister, and government professed their adhesion to Christianity, 
a great change had come over the minds of a large number of the people in Central Madagascar with regard to the ' new religion,' as also in their attitude towards it. Still, in both respects the change was very superficial, and could hardly have been expected to have been anything else.

The Christianity of thousands who professed it, when the queen did, was but a thin veneer over their heathenism or semi-heathenism. Christianity had become the religion of the queen and government, and thus became the professed religion of the great mass of the people in Imèrina, some of the outlying provinces, and most of the Hova stations among the other tribes. Christianity was professed publicly in many cases, while idolatry and the 'working of the oracle' were practised in private. Even after the majority of the people in the central provinces had built churches, worshipped in them, and become church members, heathen practices lingered among them, and died hard, as they always do. In many cases church membership was not regarded as incompatible with moral laxity, and hence suspension from church fellowship was painfully frequent. But there was nothing strange or astonishing in such a state of things. It was only history repeating itself.

As I have already said, mission work in Madagascar has always suffered in some measure from its very success. It has lacked in depth from its great extension. Hence individual dealing with candidates for church membership was almost an impossibility. During the first rush into the then existing churches, and into those that were formed just after the idols were burned, the work of the missionaries then in the island was difficult in the extreme. They could not overtake a tenth of the work that suddenly came upon them. There were so 
many pressing duties, so many village churches and preaching stations to superintend.

Then, again, it was most difficult to get at the real state of the candidates for church fellowship, even when the missionary could examine them, as they simply acquiesced in all you said, and answered 'yes' to all your questions, even when the one ' yes' contradicted the other. Thousands accepted Christianity as they accepted the queen and the Malagasy government. Many at the burning of the idols said, 'In the days of the old queen all who prayed to Jesus Christ were put to death; but now the queen herself, the prime minister, and the members of the government pray to Him, and if we don't pray also perhaps we may be punished.' So little did they know about Christianity and its teachings, and how could they have known? They simply took to 'the praying' and worshipping on the Sabbaths as to a new form of fànompoina, 'government service.' It is much to be thankful for that this ignorance and these unworthy motives were overruled for good. Thousands who, if they did not go to church to laugh, only went to do their fanompiana as they thought, became praying people indeed. Others got into the habit of attending church on the Sabbath, gradually became interested in the services, and ultimately got good. They met with the Lord of the services, and now they take rank among the most devoted and zealous of His servants.

I called on many of the squire-pastors and had long talks with them, and after thanking them for what they had done for their churches-and some of them had really done a great deal-I would say: 'You are an old man now, and not able to attend the classes for the pastors, nor the "union meetings" at the capital, and 


\section{Scanty Attainments}

might not get much good even if you did. We must also have a day-school here, the children gathered in, the people instructed, visited, and a new church built, and you are not equal to all that. Now don't you think it would be best for you to retire from the active duties of the pastorate, and become honorary pastor, and that we should get a younger man elected in your place? You would have the honour, and he would have the work. Don't you think that would be best?' In some cases I got them to retire, but in others I could not get them to move. I had to accept the inevitable and make the best of it.

In one distant church of eighty members I only found four whose religious knowledge seemed to fit them for fellowship; and yet, up to their light, they appeared devout. One could do little except pity and pray for such, and go on instructing them. I found the ignorance very gross in some cases. For example, in answer to the question, 'What must we do to be saved?' I was told in one case that we must go to church, be baptized, and receive the Lord's Supper; in another, that we could buy salvation in the market; and in a third, that we must sin in order to be saved! I mention this to give some idea of the darkness of the heathen mind, and the density of ignorance that has often to be overcome. This was what we found even in Vònizòngo when we began work there; but we had a very different state of things by the time we left. 


\section{CHAPTER VII}

\section{SHADOW AND SUNSHINE}

' Blessed is the people that know the joyful sound: they shall walk, O Lord, in the light of Thy countenance.'-PSALM lxxxix. I5.

So much for the dark and sad side; now for a word about the sunny and cheerful side of the work. One Sabbath morning, while examining the members of the church of Ambòhitràzo, an old man came forward who, in answer to my questions, told me that he could not answer them according to the catechism; for he had not learned them, as he could not read. He was an old man, he said, and it was only within the last few years that he had begun to pay any attention to religion, or even to think of preparing for a future life. He said he had not much head knowledge about religion; but he had heart love for the Lord Jesus, and was trusting Him for salvation, and that I must not judge his heart by his head knowledge. He had returned only the night before from the war in the south of the island. $\mathrm{He}$ had gone to the war all alone, he said, and he had asked God that his 'head might be covered in the day of battle'-that he might not fall, but be allowed to return to his native village; and, he added, 'God has answered my prayer; for there was no battle, and I have been brought safely back to my native village and my own church.'

I need hardly say how much good it did one to meet 


\section{A Pillar of the Church}

with such a fine old man, amid much that was not very cheering. Although he could not answer the simple questions of the catechumen's catechism, as they were therein arranged, he was far from being destitute of Bible knowledge or of the way of salvation. To all primitive and simple-minded peoples religion is always a most intensely real thing. As they advance we meet with traditional beliefs nominally accepted by all, but practically regarped by no one. Far too often what in one generation is a living faith becomes in later generations a mere dead formula, part of the religion learned by rote with which living faith has to do battle.

During one of my visits to the churches in the northern portion of the district, while examining the members of the church at Antsàmpandràno, a blind girl came forward. Of course as she could not read, she could not answer the questions of the catechism; but she had been well instructed in general Bible knowledge, and answered all the questions I put to her very well indeed. During the conversation she said she could not see Jesus Christ with the eyes of her body, but she could and did see Him with the eyes of her soul. She seemed to be a sort of 'pillar' in that small village church, as she was the leader of the singers, and kept them well in hand-a good thing, as we found in Madagascar. There, as here, 'the sons and daughters of harmony were often the children of discord.'

She had been instructed in divine things by a relative, who was a godly woman, baptized and received into fellowship in 1832 by Andriamònana, a remarkable man from all I could learn about him - a sort of 'apostle of the north.' For he not only roused the people to think of eternal things, but kept the flame of faith burning in the souls of many hidden ones during the 
'killing times.' The devoted man was hunted like a wild beast, had to hide here and there in the dens and caves of Vònizòngo, and change his name several times to escape detection by the queen's spies. Caught at last, he was sent in chains to the east coast, where he died of fever.

On the Sabbath morning, while taking a turn through the village, I came upon the old church. On entering the blind girl came out, and I think I had disturbed her at private prayer. It was evidently still a place of prayer, where some were wont to gather.

Native agents are the hope of the mission field: European missionaries can seldom do more than superintend the work. They officer the army; the rank and file of the workers must be natives. The most important thing is to be sure of your agents. 'The same commit to faithful men, who shall be able to teach others also.' There were a few such at Fihàonana, who went out on the Sabbaths to preach in the outlying villages. They generally took journeys of from five to ten and even twenty miles. They were not paid for their work, which was mainly a labour of love; but a 'present' of one shilling a month 'to buy salt' was given them. Salt was very costly in those days, and the polite way of making a small present was to give something to buy salt. Generally speaking the present went, not to buy salt, but to pay for books, a thing I encouraged. Razàka had a present of one shilling a week, for he did so much work for me, and helped in so many ways that I hardly know how I could have got on without him. He was my true yokefellow.

Five young men were under special training, preparing them for the institution at the capital for the training of native agents. But, after all my toil and 


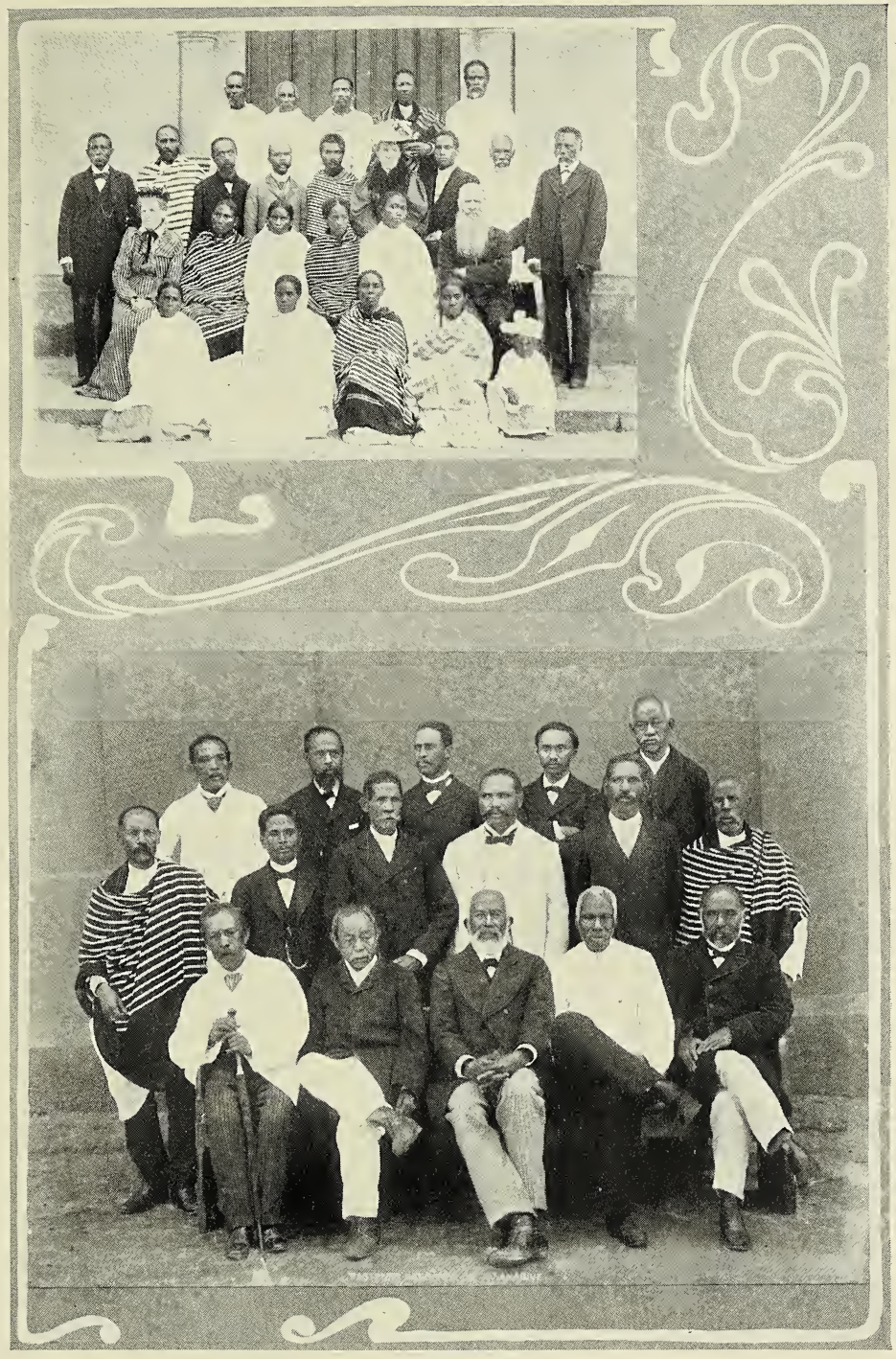

MALAGASY CHRISTIAN WORKERS.

A GROUP OF NATIVE PREACHERS AND EVANGELISTS. 



\section{Bible and Sewing-Classes}

trouble, none of them went. Three of them passed the entrance examination, but after doing so, two were sent with the army to the south, and the third would not consent to go to the capital under our conditions.

The war in the south of the island during 1873 , and the visit of the queen to the Bètsilèo country, greatly affected our churches and schools, so many having to go to the war or to follow Her Majesty. At one village no teacher could be found for the school, and the petty chief came forward and offered his services until a better could be found.

After the manse was built I felt freer to fling myself into district work of all kinds-preaching, teaching, doctoring, Bible and bookselling work, itinerating, and the work of those glorious Bible-classes, in which some of the happiest hours of my life were spent. A Bibleclass generally lasted about two, but often three hours, until I would say: 'I must stop, for I am tired talking to you.' ' Ah, sir,' they would say, 'you must be; but we are very thirsty, and have come a long way for a drink, and now we are at the well we want a good drink before we return.' Some of them had come twenty miles. I found after a time that I was going at too high pressure, had a return of the enemy of student days, and had to slow down for a time, which was hard with so much to be done.

From about a month after we settled at Fìnànana my wife had sewing-classes for the women, to which many of the girls came. It was not, however, until we got into the manse, and had a small schoolroom built near it, that systematic teaching for the girls was begun. A Scotch merchant friend sent my wife $£_{5}$ to help her with her work among the women and girls, and with this I built her the schoolroom. Having secured the services 
of a Malagasy teacher, she was able to have a fairly good school for the girls five days a week, with a sewingclass twice a week for them, and once a week in the manse for the mothers. To provide needles, thread, thimbles, and material for three sewing-classes a week soon became rather a serious matter. Another old merchant friend got us a small bale of patches and remnants of prints, calicoes, tartans, tweeds and flannels, which was of immense service to us. He sent out such a bale every year for six years. With the contents we got patchwork or parti-coloured tunics, shirts and dresses made, also vests of tweed, tartan and flannel for the cold season.

When we first settled at Fìhànana the small boys and girls wore no clothing. The bigger boys had a loincloth, and the girls a tunic. Our bale of remnants soon made a change. Of course all the garments were very much of the style of 'Joseph's coat,' but that was rather a recommendation than otherwise. We did not give any of the garments away for nothing, but sold them at from twopence to two shillings each, and the money went to help to pay the salary of the Malagasy teacher. We could always sell ten times as much as we had, in fact the garments were often bespoken weeks before they were ready.

This teaching the women and girls to sew and make garments changed the tune of the remarks formerly made about them, and instead of the old. 'She's only a girl!' and Ambin-jàvatra hiàny ny vèhivàvy, 'Women are only trifles': it was 'Yes, the girls are of some use '; 'The women are worth their salt '-which was a step in the right direction. Some of the work done by the Malagasy girls we brought home with us, and it astonished our friends very much indeed. 


\section{Women's Work}

Scant justice would be done to the work of missions, if no account were taken of the work done by the wives of the missionaries. Their work is seldom reported, and is not always reportable, but it has to be done all the same. In one sense their work is never done, for they are always at it, helping in a score of unnumbered and unsentimental ways. They visit the schools, conduct the sewing-classes, look after the Bible women, and teach the female Bible-classes. They look after the women of the churches-old folk, young folk, well folk, feeble folk, and all sorts of folk who need bits of help, and odds and ends of guidance, good advice, and wise suggestion. Besides that which cometh upon them daily-the care of their households, their small families, and the attention native servants all require.

They have to make the most of the preparations for their husbands when they go off on itinerating tourssee to his cooking-utensils, stores, stretcher, bedding, \&c. Some of them would starve by the way if their good wives did not look after them. If there are any social amenities to be observed in order to good standing in the community, as there are sometimes, the wives have to see to them, or they will not be done. They have to see that their husbands are not barbarized while about their work. Some of the husbands would go round with sleeves out at the elbows, or in their cook's white drill coat, which the washerman had by mistake put along with the missionary's, or in shoes careened over on one side and tied with twine, if their wives did not look after them. They would get to taking their breakfast in the pantry, or on their desks, or even go off into the country without breakfast, if left to themselves.

Every time they return from an itinerating tour their K 2 
wives have to put them through their facings, make them presentable to society, and not a discredit to those that sent them out. Nor is this all that missionaries' wives have to do and see after. They have to be the general supplementers in most mission fields of all manner of minor unfinished items in the round of missionary life.

In some fields the wives have to mix medicines, spread plasters, give out doses of ' pain-killer,' quinine, castor oil, warn the children against green fruit and colic, put on patches, sew on buttons, deal out bits of thread and needles, doctor the children, ask the children how their mothers are, and the mothers how the children are, keep count of the baptizing gowns, look after the preparations for the Communion Service, keep the desk supplied with pens, ink, paper and postage stamps. And so on, and so on, with twenty other things of no account in making up a 'report,' but all of which are most valuable items of solid missionary usefulness, and go a very long way in making the work of their husbands a success or a failure.

There are many gifted, cultured, gracious women, whose devotion to the cause of foreign missions is soul-refreshing to see or to read about. But there are also others, equally gracious women, although not equally gifted and cultured, whose labours, sacrifices, and influence are and have been such as even their more gifted and cultured sisters have never come near -gentle, sweet-tempered, tender-hearted, unobtrusive women who, seldom seen on platforms and never in the pulpit, and little heard of even in missionary circles, are not much reckoned among the workers and forces making for righteousness-and yet the influence, example and work of such are among the most powerful factors 


\section{Gifts, Culture, and Tact}

in the mission field. For not only do they reign as queens in their own homes-which are always models of what such ought to be in cleanliness, comfort and hospitality ("Marys in the House of God, Marthas in their own ')-but also in the huts and homes of the natives, because they reign in the hearts of the native women, who adore them, and look up to them as their highest example of all that is Christian, womanly and motherly.

With limited gifts and but little culture-as those words are generally understood-they are greatly gifted in tact, mother-wit and sanctified common sense, and rich in that heart-culture which counts for so much in all Christian work, but especially in foreign mission work. Like their prototype, Mary of old, they do what they can, and their influence and example, like the odour of her ointment, are felt far and near. For they fill their fields of labour with their aroma, penetrating to the most unthought-of places, and permeating all the ways and walks of native and missionary home, social and public life. Such are not only mothers in Israel, sisters in sorrow, and helpers in every season of affliction and time of need, but they are the Marys, Marthas, Dorcases, Priscillas and Phoebes of the mission field, and rare and precious blessings they are to it and to all connected with it.

In those early days there were very few horses, and those not good, while all were very dear. Our pastors, chiefs and other head-men, when they knew I could ride, strongly advised me to buy a horse. There were only a very few men at Fihàonana trained to carry the so-called palanquin with any comfort. Often when I wanted them they were engaged in field or other work for their masters, and could not be had. But 


\section{0}

\section{Shadow and Sunshine}

the horses were high-priced, unbroken, and riding was exhausting in the rarified air at an altitude of 5,000 feet above sea-level, and hence I was loth to get one. Nor was that all. When on horseback you could not carry an umbrella, and, even in the cold season, without one you were so beaten on the shoulders by the sun's rays as to feel after a few hours as if you had been belaboured with a stick. Walking was almost an impossibility, and would have been suicidal.

My hand, however, was forced by a strike among my palanquin-bearers. One morning, coming out of the house to go off to a district Bible-class, I found my men with my palanquin waiting for me, but before lifting it they asked where we were going, and on hearing inquired what wages I was to pay, I answered, 'The usual pay.' They said they had made up their minds that, unless I promised one shilling a day, they would not carry me. 'In that case,' I said, 'the best thing you can do is to make up your bodies to go home, for I won't pay you one shilling a day.' 'Then, sir,' they said, 'we will never carry you.' 'Very well,' I answered, 'just put up my palanquin,' which they did, and returned to the village.

I saw them in church on the Sabbath, but they did not come near me for about a month. The churches sent to see if I was ill, or why it was that I was not visiting them, nor coming to conduct Bible-classes. I told them: "My bearers have gone stupid, and refuse to carry me unless paid one shilling a day, a sum to which I cannot agree. I cannot walk to visit you, or would gladly do so. I have no horse, although I mean to get one now ; but if you will send bearers I shall be delighted to visit you, as I am weary of this inaction, but am helpless until a horse is procured.' 


\section{A Troublesome Extraction}

About a month after the refusal to carry me, on entering my study one morning, I heard a knock at the door which led into the lean-to, where patients were seen, and where there was a place for the palanquins and a carpenter's shop. Upon opening the door, a man was standing with the side of his head on his hand, groaning and looking the very picture of misery. He said he was suffering from toothache, and had been ill all night. I remarked that that was a most painful thing, and inquired what he wanted. He answered that he wanted me to draw his tooth. Telling him to sit down on the doorstep, with his head against the study door-that was the operating chair-I asked him to open his mouth, to see which tooth it was. Getting the proper forceps, I asked him where his shilling was. 'What shilling?' he asked in amazement. I said, 'I charge one shilling for drawing a tooth.' 'A shilling for drawing a tooth!' he gasped. 'Yes; you could not get it done cheaper, even if you went over to England. If $I$ went it would be much more, but as you are only a poor man I will only charge you a shilling; but turn it out quickly, as I have a deal to do to-day, and have no time to waste in haggling.'

His countenance fell; the man looked the picture of mingled astonishment and misery, while with a deepdrawn sigh-half sob-(almost too much for my gravity) he said: 'I have no shilling, sir.' 'Then,' said I, 'I can't draw your tooth,' and with that I put my forceps in my pocket. 'But how is that, sir?' he asked, 'you never charged a shilling for drawing a tooth before.' 'No,' I said, 'I never dreamt of doing so ; but then, formerly, the bond of union between us was friendship. You carried me, I paid you proper wages; and if you had 
toothache, and wanted a tooth drawn, I drew it for nothing. If ill, or your wife or children were ill, I did my best for you, and gave you medicines free; but you are dissatisfied with that bond, you wish the bond between us to be a mere matter of money. Well, just as you like. I have no wish to force my friendship upon you, or upon any one else; but if it is to be money on one side, it must be money on the other. It cannot be friendship on one side, and money on the other; it must be friendship right through, or money right through. You have a perfect right to put any price you please upon your services. If you put four shillings a day on them, when I want them I will pay for them; but when you want mine, you must pay for them, and you may find that to be rather expensive.'

A twinge of the toothache taking him at the moment, he twisted his face and seemed to writhe in agony; when able to speak he turned to me and said in the most. pathetic tones: 'Oh, sir, let's return to friendship-and draw my tooth!' Whereupon we returned to friendship, and I drew his tooth, having the most profuse thanks for my trouble, after which he went away, looking the picture of relief and happiness.

On his return to the village, he met with some of his fellow bearers, to whom he said: 'It won't do to fall out with the white man.' 'Why ?' they asked. 'If he won't pay us a shilling a day we won't carry him.' 'How will you do,' he asked, 'if you happen to have toothache, as I had, and want your tooth drawn?' 'We shall go to him,' they said, 'and have our teeth drawn.' 'But,' he said, 'it is a shilling a tooth, if you are not on friendly' terms with him, as he only draws the teeth of his friends for nothing.'

Next morning, on my going out into the yard, I found, 
to my astonishment, my bearers hanging about looking very sheepish. Saluting them, I asked after their health, and how they had been since we parted. One of them plucked up courage to ask when I was going out into the district again. I replied that I could not tell, but as soon as they came to their senses again I would be glad to go. The man said: 'Please, sir, don't mention that again!' upon which I said, 'Come to-morrow morning, then.' They came, and we never had any more trouble with them.

When we left on furlough the same men, and a dozen of others, carried my wife, our children, and myself to the coast, some 300 miles away from their own homes! They were among the last with whom I shook hands as I stepped into the boat. They were a lot of fine fellows, who carried me thousands of miles, did many a good day's work for me, and many a kindness; but they had just gone a little stupid for the time, and needed to be shown their folly, and how their principles cut both ways, and then they came to their senses again.

Once, while I was away up in the capital, my wife slipped and fell from top to bottom of the stairs. She was lifted by the servants, carried upstairs, and laid on her bed. About midnight she felt as if she was about to be ill, and, in her then delicate condition, she feared what the consequences might be if she really took ill while by herself, and so sent to the village to inform Razàka of her state, and ask him to send to the capital to call me home. He sent off two men at midnight for me. When the news reached me in the capital, I called my bearers, told them what had happened, how Madama was, and that we must start off home at once. They said, 'We can't reach Fìhàonana to-night, sir, with only 
eight bearers.' 'Well,' I answered, 'get other four, or even other eight; but we must get to Fihàonana by dark.' We started with sixteen bearers, ran the whole forty miles, and did the journey in seven hours! Twelve of the bearers broke down, and had to be left at villages on the way, to come on next day, and the four bearers who carried me in were Fihàonana men. I gave all double pay and a present, and these four an extra present. It was the quickest journey I had ever taken, and yet it was the longest; for I feared what awaited me at the end-possibly a dead wife and child. Through God's goodness I found her better than she was when she sent for me. She had lain where she had been placed for thirty-two hours, which probably saved her.

We went up to the capital in January, 1874 , to attend the meetings of the Imèrina district committee and a missionary conference, held during that month. It was not until the second week of February that we were able to start home again to our own station, and on that journey we had an exciting experience, which might have had a very tragic ending. It was the middle of the rainy season, when the rivers and streams were flooded. This made the journey with young children a trying one; but all went well, until we reached the banks of the Anjamòka, a small and usually a shallow river, about seven miles from our own home. There had been very heavy rains during the night previous, and we found the river swollen to ten times its ordinary size. The bearers refused to attempt the crossing. They said they would be drowned if they did, as the current was so strong. After waiting on the banks of the river for about an hour discussing the subject, and trying to persuade the men to make the attempt, I felt compelled at last to 


\section{A Heroic Feat}

assume a different tone, and tell them that the river had to be forded.

We had neither stretchers nor bedclothes, and we were not prepared to spend the night, within sight of our own home, on mats on the floor of a filthy Malagasy hut full of vermin. As there was no canoe to be had, there was nothing for it but to ford the river. My firm tone had the desired effect, and the men rose and prepared to cross. Four of the tallest of them took up my wife's palanquin, with her and the baby, and holding it high over their heads, entered the river. Four of their companions entered the river along with them, two swimming on the lower side of the palanquin, and two on the upper side, holding on to the poles with one hand while they swam with the other to keep the bearers from being carried away by the current. My heart was beating fast as I saw them enter the rushing stream; but it almost stood still when I saw the heads of the bearers disappear in the foaming river. I thought I was to see my wife and child drowned before my eyes. Fortunately my wife could not see what was happening. The brave fellows, when they found how deep the river was, had set their teeth, shut their eyes, and marched right on, having to take two or three steps in the bed of the stream, with their heads under water; but holding the palanquin at the utmost stretch of their arms above their heads. The weight of my wife and baby in the palanquin, and the hold which their four companions had of it, helped to keep them steady; but it was a most heroic feat.

It was with a sense of ineffable relief that I saw in a moment their heads reappear above the water; but it seemed an age. They soon clambered up the opposite bank, and the precious burden was safe. The bearers then gave vent to their pent-up feeling by laughter and 
shouting, returned for the other two children, their nurse, and then myself.

Having forded the river once, they were quite prepared to do it fifty times if necessary. After we had all been brought safely over, the men started again laughing, dancing, and fairly yelling for joy. 'What a set of cowards we are,' they said, 'if it had not been for the white man, we should never have attempted fording the river.' I thought within myself, if you only knew it, the said white man would never have asked you to make the attempt, if he had had any idea of the risk that you would have to run. It would have been far wiser, however uncomfortable, to have waited for another hour, or even two, on the banks of the river. However, we reached home just at dark, and had soon forgotten the perils and discomforts of our journey.

As I have already said, the war in the south of the island, and the visit of the queen and court to the Bètsilèo country, greatly affected the attendance at church for a time; but on Her Majesty's return to the capital the tide turned, and the churches were soon as full as ever. Immoralities also declined; we had fewer scandals and fewer cases of church discipline than we had ever had. A Christian public opinion gradually grew in the district; sin began to hide its head, and people to become ashamed of what they had formerly gloried in. As the result of God's blessing on our efforts to spread the Gospel, real religion took root in the hearts of our people. Several who had been suspended from church fellowship, under the influence of the Spirit of God professed sincere sorrow for their sin, and showed great anxiety to be received back into the church, and to be numbered again among God's people.

One man in particular, who had fallen into sin, and 


\section{A Garment for a Bible}

that too in spite of all our warnings and advice, was brought to repentance by repeated strokes of affliction, and the death of one dear one after another, and of his companions in sin. For a time he only rebelled more and more beneath the rod, but at last he came to himself and said: 'Well, it's no use going on like this; for this is God dealing with me for my sins, and there is nothing to be gained by going on fighting against God, and the white man's advice.' He came to us and professed sincere penitence, and was received back into church fellowship, a sadder and a wiser man.

We got out the first edition of the Malagasy Bible, at the cost of one shilling, in 1873 ; and the whole consignment of 6,000 copies was sold in six weeks, and 10,000 could have been sold, had they been there. There were many most touching incidents connected with the sale of those Bibles; but it would take up too much space to tell more than one.

A man went to one of our missionaries one day, and asked for a Bible on credit, as he was afraid the Bibles would be all gone before he could get a shilling, promising to pay for it the following Friday. My friend said, 'No, I can't give credit, bring the shilling and you shall have the Bible.' The man went away, looking sad; but he returned after a little, bringing a shilling and demanded a Bible. He was asked, 'Why did you want a Bible on credit, when you had a shilling to buy one?' 'I had not a shilling, sir,' he replied. 'Where then did you get this shilling?' he was asked. 'I went to the market,' he answered, 'and sold my garment, and for it I got a shilling!'

Our general Bible-class at Fihàonana on Sabbath afternoon for old and young, instead of the afternoon service, proved a great success. Of course we had 
a deal of hymn-singing, for a number of new hymns had been published, set to very lively tunes-hymns and tunes were mostly adaptations from Messrs. Moody and Sankey's book-and that of itself was a great source of attraction. But we had also Bible reading, exposition, and catechizing, and I believe that much of the more intelligent attention I began to get on the Sabbaths, when I preached at Fihàonana, was due to the teaching and catechizing of the Sabbath afternoon class.

Our people at Fihàonana were very excited over the building of our model station church-the Martyr Memorial Church, at the home of the martyrs. The old persecuting queen-Rànavàlona I-made a great mistake for us when she took the Christian converts from Vònizòngo, and made martyrs of them in the capital. If she had only been content to make martyrs of all of them-as she did of some of them-at their own native villages, we should have got the memorial churches for them in Vònizòngo, instead of their being erected in the capital for congregations that had no connexion whatsoever with the martyrs. Some of them were not formed until after the reopening of the mission in 1862 . They got these fine memorial churches, built of block granite, without a penny of cost, while the district from which the martyrs came had to get its own as best it could. Still, after a deal of work and effort we got a church built, which was a comfort to the community, an ornament to the countryside, and, above all, worthy of the home of the martyrs. This repaid us for all our toil and sacrifice.

I had some of my local preachers, deacons, and members taught bricklaying, while our manse was being built, so that we might be independent of the bricklayers of the capital for the building of our new church, when 


\section{Labours of Love}

we were able to have one. They gladly and generously built the walls for one-fourth of the regular pay for bricklaying, to keep down the cost of building. The congregation at Fìàonana raised $£ 20$, equivalent to $£ 100$ to them, while the churches of the district raised $£_{3} 2 s .6 d$., equivalent to $£ \mathrm{I}_{5}$ I $2 s .6 d$., to help us. These may seem small sums, but they were really large for the people to raise at that time. The members and adherents at Fihàonana made 100,000 bricks for nothing.

We had no forced labour, such as there was at the building of some other station churches, under the sway of the 'Palace Church Evangelists.' We had agreed not to ask the old chief to help us, as we knew that it would only mean his calling his clansmen, and setting them and their slaves to making bricks for us. We were determined we should not have that, and so we left all to the voluntary efforts of those really interested in the church. The old chief did not like our way of getting the church built, as it gave him no prominent place in the work, as chief, and he accordingly took umbrage, and stood aside for a time; but when he saw that the work went on without him, he came forward and made offer of his services, and really did a good deal to help us, poor old man. I say ' poor old man,' because I felt for him. He was a member of the church, he was so before we knew him; but I fear he was not a member of Christ. Yet he knew the truth, and I believe it often troubled him, and he dared not do the things he had formerly done. $\mathrm{He}$ was a son of the first convert to Christianity in Vònizòngo, and hence was a brother of Ràmitràha the martyr. He had been a pupil of the first missionaries, along with Razàka, but had lapsed and drifted.

Our work was interrupted for a time, first, by the protracted committee meetings, and the missionary 
conference at the capital, from which we did not return until the middle of February, and then, by the serious amount of affliction through which we were called upon to pass. My wife and children were ill together for about three months; she so seriously ill, that she was brought to the brink of the grave; but God in His goodness spared her to her children and me. The anxieties, and the nursing, proved too much for me, weakened as I then was by my attempts to overtake all the work of the two districts, which had been committed to my care, and so, just as they recovered I was laid aside for a time from full work. While unfit for full duty, I dashed off some 800 pages of letters to friends at home, asking for help for the building of our new church, and by that means was able to raise EI 50 !

On our return to our station, I began regular classes for pastors and local preachers at four centres-two in the northern portion of the district, and two in the southern. To these I went once a fortnight, going to one north and one south every week. My wife was able to go with me to these centres, and have sewingclasses with the women and girls. Travelling as I now did on horseback, she was able to have my former bearers. At all the four centres she had large and most interesting classes, of about fifty women and girls. She had also her sewing-class at Fihàonana twice a week. We found, however, that we had in our zeal attempted too much. My wife suffered for it afterwards. A journey of twelve miles twice a week under a tropical sun-trying even in the cold season-in addition to domestic duties, and all the other work of the week at a mission station, proved too much for her, and no wonder. 


\section{Schools and Progress}

Of the state of the village schools (1873-1875) little can be said, and the less the better. Poor at best, they had been allowed to drift to ruin, and all my former toil and trouble over them seemed wasted. And yet there were signs of a growing interest in elementary education on the part of the people, which had only to be laid hold of, and directed into proper channels, to be made serviceable. Schools would not rise of themselves in Madagascar, any more than anywhere else. That they could be raised and kept up was afterwards proved. I had the honour and satisfaction-no small satisfaction to me-of doing what had never before been done, and has never been done since, namely, of raising forty-four new schools during seven months, and gathering two thousand four hundred children into them! It was certainly about the hardest seven months' work I have ever done, and perhaps I know what hard work means; but it was well worth doing. These schools were kept up for five years, until we were driven home on furlough, after being again and again prostrated by malarial fever. Instead of some hundred and fifty, old and young, whom we found able to read the Word of God, when we settled in the district in $187 \mathrm{r}$, we left three thousand able to do so, and in possession of the Book-no bad ten years' work of itself, even if we had done nothing else.

While detained in the capital through the illness of my wife and children in $1874, \mathrm{I}$ had a hint from a friend at court that the queen was about to issue a proclamation with regard to education, to the effect that all children must attend some school. And so, as soon after our return to our station as I could, I set to work to get the children of the district gathered into schools connected with our village churches. It was the dry season, and 
I went galloping all over my district, visiting the churches, and getting them roused to take action along with me. $I$ attended the local markets and fairs, where I appealed to the people to send their children to school. I called on the chiefs, petty chiefs, and head men to come to my help in the interests of the education of the rising generation. I got them, the pastors, and the local preachers formed into village school-boards on a small scale, and made them responsible for the attendance of the children of their neighbourhood at school. Three, four, and even five days a week for some seven months I devoted to this, with the result already mentioned.

It was very exhausting work, and I often came home at night so tired that I could hardly come off my horse. My wife and children would be waiting for my return from these expeditions, and she often told me, with tears in her eyes, that I was killing myself. This work was worth much, however, and had to be done then, if done at all, and the children were to be saved. When the royal proclamation came out, I had the names of two thousand four hundred children in the schools under my care ready to hand in to the government. Neither priest nor prelate could interfere with them, nor could any of these children be removed without Her Majesty's orders.

Of our school work, Dr. Mullens wrote in 1875 : 'We are greatly struck with your educational success; however have you managed to gather so many village schools, and fill them with so many scholars? I suppose you have managed to impart some of your own enthusiasm to the people! Well, it is a good work, and I trust God will bless it abundantly.' And again in 1876 : 'You have sent us two capital accounts both of the general work and of the examination of the schools. We have been 


\section{Modes of Mission Work}

much struck by the development of education in your district.'

Whatever may be the views adopted by some supporters of missions, as to the wisdom of devoting missionary energy and funds to educational work in other mission fields, in Madagascar such work has always been regarded as of the greatest importance. Unless the first missionaries had established schools, the people must have grown up ignorant, and the translation of the Scriptures would have been utterly useless, as none would have been able to read them. School work has therefore been carried on at all our stations, and in connexion with almost all our village churches, and some of the best work that has been done in the mission has been done in the schools, where the minds and memories of the children have been charged with Gospel truth, which was able to make them wise unto salvation.

Distinctions have been drawn-sometimes absurdly enough-between what are called evangelistic and mere educational work. It is true there is a sense in which distinctions may be drawn; but all educational work in the mission field ought to sustain a vital relation to evangelization. The same may be said of literary and medical mission work. In some fields, medical missionary work constitutes an absolutely essential factor. Still, all these instrumentalities are but means to an end. The value of educational, literary, medical, and all other forms of missionary activity must be measured by the extent to which they prepare the way for the Gospel, and promote its acceptance by the natives. They should manifest its spirit, and multiply the points of contact with the life of the people, and thus increase the efficiency of those who preach the Gospel. 'The test of every 
religious, political, or educational system is the man who is formed.' 'Ignorance the mother of devotion' has never been the watchword of Protestantism at home or abroad. It expresses the policy of a very different order of religious teachers.

Having got my forty-four new village schools raised, and two thousand four hundred children gathered into them, the next thing was to get teachers. Where was I to find them? It had been difficult enough to provide for the few schools of former years. "Take what you have and you'll never want,' 'God helps those who help themselves,' are good old sayings. On these I acted. There were a few old soldiers in the district who knew the alphabet and understood discipline. I appointed a number of them village schoolmasters at the enormous salary of one shilling a month! That was poor pay, but then it was poor teaching; the pay and the teaching were about equal. But my soldier-schoolmasters earned their one shilling a month, and as they got no pay as soldiers they were glad to get even one shilling a month ; and I could have got a hundred of them at that figure if I had wanted them. As I have said, they earned their money; for they taught the alphabet well, and they maintained discipline in the schools. This was of the greatest importance, as it is utterly neglected in Malagasy families. I have seen boys even in Britain whom I could have wished to place under my soldier-schoolmasters for six months. They would have taught them what discipline meant, and how to behave themselves.

As an example of how well they taught discipline I mzy mention that one day, after we had removed our station school up from the new church to the new schoolhouse in our own yard, I went down and found three boys there after the school had been dismissed. I asked 


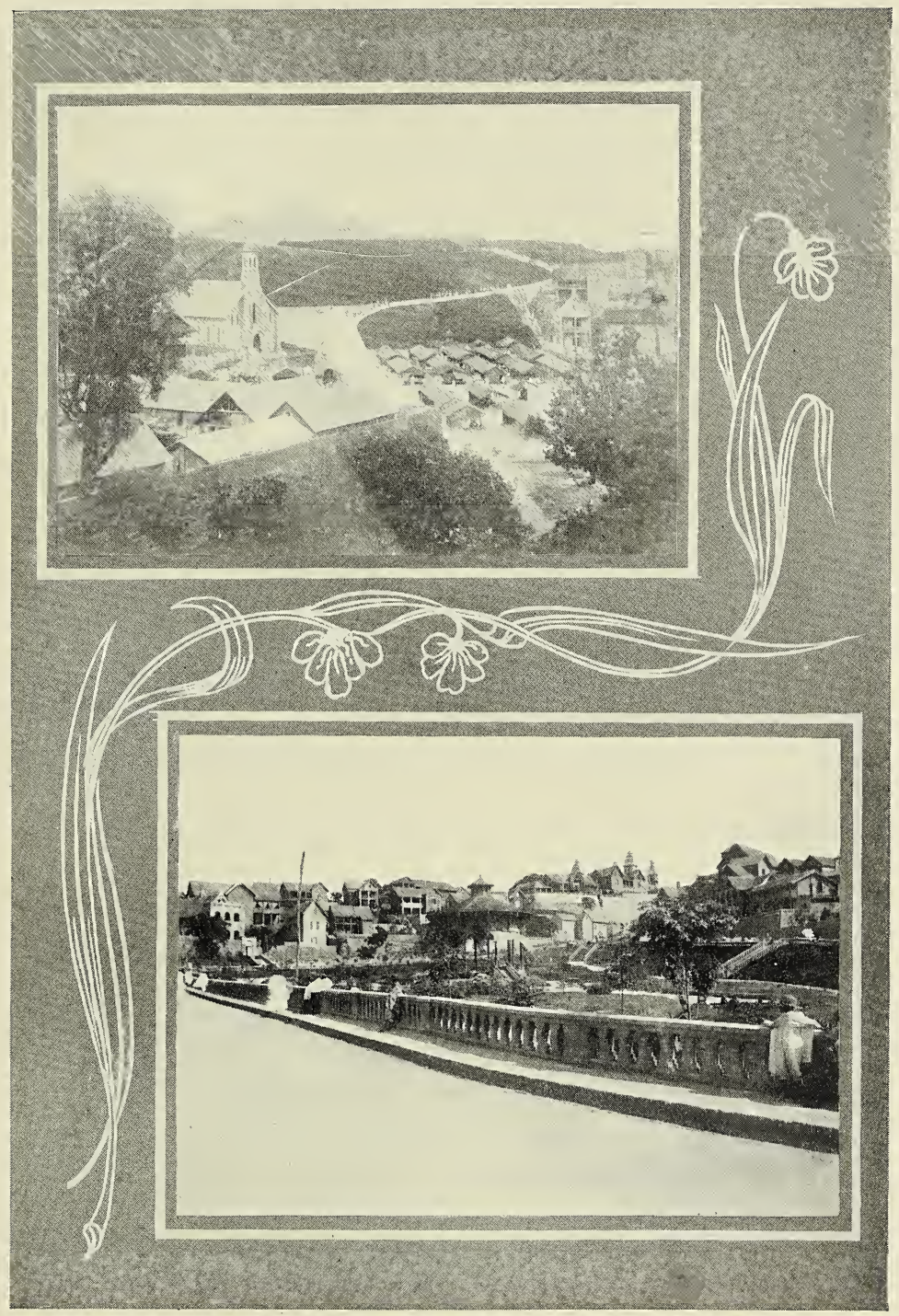

ANALAKELY : CHURCH AND MARKET-PLACE. THE PIAZZA, ANDOHALO. 



\section{Soldier-Schoolmasters}

why they had not gone home when the school broke up, and they replied that they had been left, while the schoolmaster went to his dinner, to learn their lesson, as they had not known it properly. I asked them if they had learned it; they said they had, and I then asked for what they were waiting. They said they were waiting for the schoolmaster to return from his dinner to hear their lesson. These boys were sitting in an unfinished school-house; it had neither doors nor windows, only the walls and the roof, and yet they did not dream of running away.

Of course I very soon found that by such appointments-although the only ones then possible-I I had only removed my difficulties a step. Soon there were a series of deputations to ask for more advanced masters. I often heard a knock at the outside door of my study, and opened it to find some six or eight half-naked Malagasy boys. To my inquiry as to what they wanted, they said they were a deputation sent to see me on business. I invited them into my study. The boy who had been appointed spokesman then stood up and addressed me as follows: 'May you reach old age, sir, may you never be weakly, may you reach grey hairs with your wife and family!' 'Yes,' I answered on these occasions, 'thank you for your good wishes; now what is the business?' When you are saluted in that elaborate way, you may be certain that there is something of importance to follow. The lad continued, 'We have been appointed as a deputation by the school at such a village to wait upon you, and ask for a schoolmaster.' I would then look up my book, to find, of course, that they had a soldier-schoolmaster. My reply usually took this form: 'You have a teacher at that village.' 'Yes, sir,' the lad would answer, 'but he can't read, and 
we can, and so we want a schoolmaster who can read!'

Of course, with teachers who could not read, you could hardly expect the schools to make very rapid progress. There was nothing for it but to take some twenty of the brightest boys from the various schools to my own station, give them a few months' special training, and then send them out as teachers - to teach a month, and then return and learn a month-and while they were teaching they got a penny a day. Some of the sharpest of them were then picked out, and passed on to the normal school at the capital, where they get a two years' training. A grant of sixpence a week was obtained for their support while at the normal school; and before we left on our first furlough there were sixteen trained teachers at work in the district, and most of them have been at work there since-some as teachers, others as pastors, and others as evangelists. A large government school of some four hundred boys is now taught in that schoolhouse built in the manse yard. The three principal native teachers in that school are old lads of ours that had been sent to the capital for a normal school training.

The activity in regard to the schools in our district startled the western district into activity; then the districts to the south and the east, and other districts, followed suit, and soon there was a greatly increased number of schools at work all over the central provinces.

Twenty-four lads went up to the normal school entrance examination in 1874 , but only six passed. Also two of our best and most capable women were sent to the hospital to be trained as nurses. After their return they did a good and much-needed work in the district for many years. It took time and hard fighting, however, 
to overcome the old heathen practices. Prejudices and superstitions die hard. Under the old heathen methods, fully a third of the women died during 'nature's hour of sorrow'; but our trained nurses soon made a great change in that respect, and so established their reputation.

A vast amount of splendid and much needed work was done at the Medical Mission Hospital for over thirty years by the various Medical Missionaries in charge of it. Perhaps the most thorough and valuable service rendered even there was the work done by the Matron Miss Byam (the Miss Nightingale of Madagascar), daughter of the late General Byam, in the training of a staff of Malagasy nurses. Nothing more effective in connexion with the Mission was ever done in the island. 


\section{CHAPTER VIII}

\section{DISTRICT JOURNEYS AND INCIDENTS}

'Happy is the people, that is in such a case: yea, happy is the people, whose God is the Lord.'-Psalm cxliv. 15.

THE year 1875 was by far the best since we came, in work done and progress made, in schools established, in money raised, in enlarged congregations, and in the fewness of scandals. We had to remember for our comfort that we were but breaking up the fallow ground, preparing the soil and sowing the seed of the Kingdom, and that it was too soon to look for a harvest. We found that there was great truth in the remark that 'after a religious creed has been established in a community'-as to some extent at least it had been in Vònizòngo-' the preacher educates gradually, far oftener than he converts suddenly.'

By degrees the Gospel became a power in the land. Old things passed away, and all things became new. The whole face of society was quietly revolutionized, and changes effected in matters social, political, and religious. Everything in fact, from the fireside to the forum, and from the queen on the throne to the prisoner in chains, felt the new influence. It was perhaps a matter for more thankfulness than we were always prepared to admit, that we had experienced so little of the sensational, the startling, and the marvellous; although from another point of view, the work might well be deemed a marvellous transformation. 


\section{Unworthy Pastors}

During that year we had several exhibitions of the power of the people to apply the knowledge acquired. I might give many instances, but let one suffice. The church at Antsàmpandràno had given much trouble from the time of its formation, in fact more trouble than all the other churches of the district. This had arisen almost entirely from the fact that there were seven àndriandàties (petty chiefs) in that village, and they all wanted to be leaders or pillars in the church. All desired to be pastors, preachers, or deacons, although there was not one of them fit even for church fellowship. They were all bad. But notwithstanding this, when the church was formed in 1865 , as it was almost entirely composed of their own clansmen and slaves, two of these petty chiefs were chosen pastors and two preachers.

As Antsàmpandràno was a long way from Fìhàonana, I had not been able to visit it often (although I had visited it much oftener than many of the other churches) hence it was some time before I came fully to understand the real state of matters. Even after I did so, I found it quite impossible to take action, as I could find no pretext for expelling these men from their office and membership. No one was bold enough to bring any charge against them. This was little to be wondered at. At last, however, the two pastors and one of the preachers had a quarrel with the other preacher; and these three entered his hut, while he was in bed, beat him in a most brutal manner, leaving him bruised, bleeding, and senseless. $\mathrm{He}$ appealed to the queen, and his assailants had a narrow escape of being put in chains; but, I suppose, they had managed to bribe the judges and so got off. When I heard of what had taken place, I called a Quarterly Meeting of pastors, teachers, and deacons to meet at Antsàmpandràno, to suspend these men from office and 
fellowship. When we arrived at Antsàmpandràno, we found that this had already been done. The small church, mainly composed of their own clansmen and slaves, had expelled their chiefs and masters from church membership. The Quarterly Meeting of course ratified what the church had done.

After behaving fairly well-outwardly at least-for a year, these men applied to be restored to church fellowship; and the two teachers-whom the Quarterly Meeting had placed in charge of the church-sent on to me to ask what they were to do. I sent back word that neither they nor the church could do anything, as only the Quarterly Meeting could restore to membership in such cases. For we had been compelled by our peculiar circumstances to pass a by-law, that if any one was suspended from church fellowship, only by vote of the Quarterly Meeting could the party be restored. We had been compelled to pass this by-law because we found, when any of the petty chiefs or head men were suspended from church membership, generally they had only to say they repented, and they were restored to full communion, or if they were not, they managed to make things very uncomfortable for both office-bearers and members until they were. We had, therefore, as a body, to come to the rescue of these weak and harassed churches, in order to put a stop to such a state of matters. All suspended persons had to be restored by the Quarterly Meeting and not by the individual church as formerly.

After a time these men applied to the Quarterly Meeting to be restored; but we were unanimous in the opinion that they were unfit for church membership, and ought not therefore to be readmitted. At this they were very much astonished and angry. On the way home from the meeting, they managed to intimidate and terrify 


\section{Brave Church Members}

their slaves (who had been the representatives of the church of Antsàmpandràno to the Quarterly Meeting), so that theydid not report to the church that their masters had been refused readmission. It was such an extraordinary thing for chiefs to be refused anything, that I suppose the church had taken it for granted that their application had been sustained, and they were received to the communion the following Sabbath. We heard on the Monday what had been done, and I sent on at once to inform the church that they would be cut off from all connexion with us, unless these men were at once expelled. On the Wednesday following, the two teachers, along with the deacons of the church, came to see me, and discovering how matters stood, they returned home, and to their credit be it told, notwithstanding threats and attempts to intimidate and terrify them, the small church, mainly composed of clansmen and slaves, expelled their chiefs and masters from fellowship, as being unfit for communion in the Church of Christ!

The three men came to our next Quarterly Meeting, but we again declined to restore them, and told them that we did not believe in their repentance; that we did not believe they were converted men, and would not receive them into church fellowship again, until we had good reason for believing they were. That we did right was proved shortly afterwards by the fact that one of these men, who had been chief pastor, was wanted by the queen for knocking out a man's eye!

The total amount raised by the churches of the district during that year was large. This was an encouraging sign of progress, and of the hold of their religion on the hearts of the people. They had little money, and what they had they did not readily part with. The sum raised - exclusive of the usual church expenses-amounted 
to $£ 62$ i2s. od., equivalent to $£_{3}{ }^{1} 3$ ! This too from a people who divided their money down to the fifteenth part of a penny, and who, ten years before, had not raised $£ \mathrm{Io}$ in the interests of religion.

We were delighted on our return from our enforced holiday in the capital to find our new church thatched, and that the people had been so diligent and active in our absence. It proved that they had profited by our instruction and example to an extent for which we had not always given them credit.

On our return I set off on an itinerating tour through the two districts. Itinerating was very trying work in those days, mainly in consequence of the filthy huts in which we had to sleep, often with pigs and poultry on the other side of a bulrush partition, and with a copious supply of vermin. I was seldom allowed into the house on my return home, until I had changed my clothes. Boiling water had to be poured over my under-clothing, and the rest of my garments aired for days, brushed, and minutely inspected before they could be worn again.

On this tour I had quite a novel experience. I had misjudged the distance to a large village, at which we were to have a Quarterly Meeting next day. At sunset we found ourselves a long way from it, and as it becomes dark quickly after sunset, we were compelled to turn aside to a miserable collection of some half-dozen bulrush huts on the ridge we were crossing. After tea, feeling tired, and not quite up to the mark, I turned in, and was soon fast asleep. I awoke to find I was being turned out of bed. An enormous pig had pushed aside the rush door, walked into the small hut in which I was sleeping, got under my stretcher, and turned me out of bed. I awoke struggling on the floor of the hut with my huge, dirty, uninvited visitor, whose grunts brought 


\section{An Uninvited Visitor}

me to my senses. As I heard my men talking, I shouted for them. They immediately came. 'Why did you allow this beast in upon me?' I asked. 'How could we prevent it, sir ?' they said. 'It was roaming about, and pushed its way through the door into the hut.' 'Well,' I said, 'take it away and tie it up, and prevent its return here.'

I did not fall asleep after that. The night had become so cold that I could not sleep. Being, as the village was, on an eminence, the cold east wind blew through the frail tenement with chilling effect, all the more that it was the middle of the cold season, when the nights are often piercingly cold. I was glad to get up, long before daylight, rouse my men to get my coffee and quinine, and be off for the village where our gathering was to be held, and where we had a Quarterly Meeting in the enjoyment of which I soon forgot the discomforts of the night. By sunset $I$ was in my own house again.

I have heard of men telling of sleeping in huts in Madagascar, with scorpions crawling over them, snakes hanging from the roof hissing in their faces, and of being taken out in the morning, set up to be speared, and only waiting to hear the 'Klick' (which does not exist in Madagascar) as the signal for being speared! All such are but 'travellers' tales,' the product of disordered livers or diseased imaginations. The scorpions were only cockroaches or rats; the snakes, long festoons of soot, such as hang from the roof of most Malagasy huts, which have no chimneys; the being taken out and set up to be speared, only a dream, probably the effect of too hearty a supper after a long exhausting day's journey! There were discomforts and difficulties in those days; but they were hardly worth mentioning, when compared with what have to be faced in some 


\section{District Journeys and Incidents}

mission fields, such as New Guinea, the Congo, and Central Africa. Hotel accommodation cannot be expected in the mission field, and those who look for it ought to remain at home.

The Quarterly Meetings grew to be sources of great strength and usefulness. They were the means of uniting all in the common work. I declined to decide cases of dispute, church discipline, or other serious business as an individual. I laid the graver matters before the Quarterly Meeting, and settled them by the vote of the majority. By means of these meetings, pastors, local preachers, deacons, and church members were trained in habits of self-reliance in dealing with the difficulties that were always cropping up in newly formed churches, as well as with general church business. We had, as a rule, good meetings, and not a little to do. I was ex officio chairman, and by the exercise of a little tact, generally got them to vote as I wanted.

We had a fine station school at Fìhàonana. The girls, one hundred and fifteen in number, were taught in the small school-house in the manse yard, to be near my wife; and the boys, one hundred and twenty-five in numberinstead of twenty-five as formerly-in the church in the village. Here, as elsewhere, the great change in the number of the schools and the scholars was mainly brought about (apart from the royal proclamation with regard to education) by interesting the local authorities in the education of the children, by making them members of the village school-boards, and leading them to induce the parents to send their children to school.

I give here an illustration of the good done by Bible teaching, especially among the young. A little Malagasy girl was brought to Antanànarivo from the north-west province of Madagascar, and placed in the 
Friends' High School for Girls, at that time under the charge of Miss Helen Gilpin. Miss Gilpin made the imparting of Bible knowledge a very special feature of her teaching. The girl was quick at learning, as most Malagasy children are, and was very diligent; she made extraordinary progress in all subjects, but in no subject more than in Scripture knowledge.

The stories of the Bible threw a spell over her; she was fascinated with them as she had never been before by any stories, so she was never weary of listening to the Bible being read to her, until she could read it for herself. The story of the Flood; of Noah and his family in the ark; of Joseph and his brethren; of the wonders at the Red Sea; of the wanderings of the children of Israel in the wilderness; of the death of Moses on the mount; of the three Hebrew youths in the fiery furnace; of Daniel in the lions' den-were there ever such stories as these?

Those of the New Testament were no less captivating. There was the visit of the Wise Men from the East, led by the star, seeking for the infant Saviour; the flight into Egypt; the murder of the children of Bethlehem ; the calling of the Apostles; the conversions on the Day of Pentecost; the conversion of St. Paul, and his travels, \&c.

Then the parables and the miracles. But most wonderful and heart-stirring of all, there was the death of the Saviour on the Cross! These filled the mind and memory of that little girl by day and her dreams by. night, and were as real as anything that happened to her in her own life.

After being ten months at school, her mother came up from the west to take her home for the holidays, which lasted two months. The journey took two days 


\section{District Journeys and Incidents}

to accomplish. At the end of the first day, they entered a village to spend the night there, intending to continue their journey the following morning. While the rice for supper was being boiled, they all sat (teo amorompàtana) round the hearth and chatted, and the little girl and her mother were asked many questions-where they had come from, where they were going, why they had been in the capital, \&c. The little girl told how she had been at school in the capital, and what she had learned there, and began relating some of the Bible stories, as samples of the knowledge she had gained.

After supper, at the request of the people, she continued to tell more of those wonderful stories, and also what she knew about the 'New Religion,' and its Author Jesus Christ ( $N y$ Zànak' Andriamànitra Andriananahary, 'the Son of God the Creator'). It was very late before they lay down on their mats to sleep, and hence it was late before the little girl and her mother rose the following morning.

They at once prepared to continue their journey home. To their astonishment, however, the people would not hear of this; they said they wanted to hear more of those delightful stories, and also more about the book from which they were taken, and the 'New Religion.' They advised the girl and her mother to rest for the day, and promised to provide food and lodging free, if they would remain another night with them. This they did, and the evening and up to midnight was spent as the previous one had been. A number of the neighbours, who had heard about the wonderful stories, came in to hear for themselves, and they also were enthralled by what the little girl told of the 'New Religion' and by the hymns she sang. On the following morning, before the girl and her mother could start on 
their journey home, they were waited upon by a deputation of the villagers to ask them to stay another night, that they might hear still more of the wonderful tales. They said they would provide rice and 'laoka' (kitchie) for them, give them a larger and cleaner hut in which to stay, and into which the people could come together in greater numbers to listen. Once more they consented to remain another night.

Next morning there was another deputation from the other end of the village, asking them to come to their end, and tell them those delightful stories there. The result was that they had to remain for a week in that village, while the little girl night after night to crowded houses told Bible stories, sung her hymns, and all she could tell about the 'New Religion.'

They had to remain over the Sunday, and that little girl had to tell her stories, sing her hymns, and tell all she knew, from morning to midnight, such was the anxiety of the people to hear her. Their eagerness for information about the wonderful 'New Religion' was intense, and this thirst for knowledge grew until a congregation was gathered in that village. At first they would simply meet on the Sunday, sit quiet for an hour, and then break up. Some one with a good memory, perhaps, would retell what of the Bible stories he remembered, or they would sing over and over again all they remembered of some of the hymns they had heard; and so they went on. Afterwards a church was formed in that village, and to-day there are five-and-twenty village churches and five-and-twenty day schools within a circle of five miles of that village, where the little girl and her mother lodged, and where she began telling the people those wonderful Bible stories.

That little girl has been for many years among the 


\section{District Journeys and Incidents}

best and most devoted of the workers for the Kingdom of God. She did what she could, and has kept on doing so, and her efforts were greatly blessed by Him in Whose service the Bible stories were so effectively used.

At our first school examinations in 1874 , our schools were found to be in a very poor state, and very deficient in elementary Bible knowledge. This was just what might have been expected. I expressed my sorrow at their state. The people also said they were sorry, but they explained that most of the children had only been under instruction for a few weeks; and as the majority of them were children of heathen, or all but heathen families, but little interest had been taken in their progress by their parents. They hoped to have them in a much more satisfactory state next year, and they had. During the following few weeks, three hundred copies of the elementary catechism were sold. The altered condition of the schools led to a very great increase in the sale of first lesson books, catechisms, Bibles, Testaments, and school material. More were sold during that year than during the previous four, and $£$ I 20 was paid into the printing-office that year. Of our Malagasy monthly, Good Words, 3,ooo copies, and 3,000 elementary catechisms were disposed of.

The old superstitious fear of the white man's medicine kept rapidly dying out, as the knowledge of its good effects spread, especially that of Odi-tàzo, quinine. We had a more severe fever season that year than we had previously known. We were the more impressed by it through the increased number of those who sought our aid. Eight ounces of quinine were sold during the seven months.

A member of the mission, going home on furlough, wished to try the west coast route, to catch the steamer 


\section{Enforced Repentance}

at Mojangà, instead of having to take fifteen days on a 'Bullocker,' with two hundred bullocks for fellow passengers, between Tàmatàve and Mauritius. From the report of the state of the churches on that route, brought back by the member of the mission who conducted Dr. Mullens and Mr. and Mrs. Pillans to Mojangà, it was thought it would be well to send another member of the mission with the one going on furlough. They could both visit the churches, do what they could for them, and the one who was to return could bring back a report of their state, and what might be done to help them.

At one village they had a church meeting, at which they noticed that one of the members was under the influence of drink. They called the pastor's attention to his state, and said that such a person ought not to be allowed to continue in church fellowship, and that he must leave the meeting now. The pastor beckoned to two of the deacons to remove the offending member, and the business of the church meeting went on. As there was much business to be got through, much to explain, and much advice to be given, the meeting lasted some three hours. It was just about to close, when the pastor whispered to the two missionaries: 'He has repented and wishes to be received back into church fellowship.' They asked: 'Who has repented?' To their astonishment they were told that the intoxicated member, who had been removed from the church meeting some three hours before, had repented, and was anxious to be received back into church fellowship. They said: 'Nonsense, he can't have truly repented. $\mathrm{He}$ must be still under the influence of drink.' 'No, sirs,' said the pastor, 'he has truly repented, and is now quite sober; for the two deacons thrashed him into 
repentance, and until he was quite sober, for so disgracing us all!

The year 1875 had been by far the most prosperous year we had had, and the year 1876 was the most eventful to us and to the whole mission. The country then passed through a great crisis. It underwent a social revolution, second to none, perhaps, that it had ever encountered. A greater change took place than that which followed the death of Radàma II, or of Queen Ràsohèrina, and all without blood. The central, and even the distant provinces were for months in a state of great excitement, caused mainly by two things: a conscription for the native army, which was really a revolutionizing of the whole military system, and in the main tended to its improvement; though this reform in the end failed through treachery; and secondly, an extraordinary excitement which arose on the subject of slavery, brought about by indiscretion and the circulation of false reports. It was currently reported, that the slaves were all to be emancipated, and if they were not, the British, headed by Queen Victoria herself, were coming to free them by force!

Of course such a state of affairs affected our work for a time, though it did no permanent harm. Our work was almost brought to a standstill. If I had not had the finishing of our new church to occupy me, I should have had rather a miserable time of it. The district Bible-class had to be given up, many schools had to be closed for want of teachers, as most of the pastors, local preachers, and teachers were called to the capital. Many of the adherents, and some even of the church members, fell away for a time from the means of grace.

Some of the adherents, when they found that attendance at the church on the Sabbath was not compulsory, or 
Sabbath government service, as many of the more ignorant had always thought it was, and that they might leave off attendance with perfect safety, did so. Rumours set in circulation by the old heathen party were rife to the effect 'that the queen had no longer any love or respect for the New Religion, and was about to put a stop to all praying, and close all the schools.' Heathenism dies hard. Some of the adherents who left us for a time did so from fear; for the people had been terribly cheated once, and it took a long time before they had a thorough trust in any government. They returned to us after the scare was over; for the ' good seed of the Kingdom ' had found a lodgement in their hearts.

The queen set twenty of our pastors free from government service, and among them Razàka, and sent them home to attend to their pastoral duties, and to do what they could to help forward the good work. They were told they were to attend to the interests of the people, the churches, and the schools of their respective villages; and that that would be taken in lieu of government service.

All the pastors and teachers were ultimately freed from government service, and this was a great boon to the churches and the people. Our Quarterly Meetings went through the list of our pastors, and sent it to the government, so tha none might pass themselves off as pastors or teachers to escape the hated fànompiona.

During the conscription, the prime minister, as commander-in-chief, asked one man why he was so anxious to be freed from military service; he replied, because he was a pastor. 'Were you chosen by the people?' he was asked. 'Yes,' the man answered. 'Has the missionary of the district confirmed your appointment?' 'Yes,' 
182 District Journeys and Incidents he replied. 'Can you read?' he was asked. 'Not much,' the man replied. 'Can you write?' 'No,' he said. 'What can you do then to benefit the people?' 'Well,' he replied, 'I do my best for the good of all and for the children in the school.' 'That's right,' said the prime minister, ' go home and continue your good work ; you are free.' 


\section{CHAPTER IX}

\section{DEVELOPMENT AND CONSOLIDATION}

'And they shall not teach every man his fellow-citizen, and every man his brother, saying, Know the Lord: for all shall know Me, from the least to the greatest of them.'-HEBREWS viii. II.

I GOT a fellow missionary to visit our station once a month for six months to teach singing. The class, which was conducted on the sol-fa notation, did our people much good. They enjoyed singing and learned the system readily, and our congregational singing vastly improved. I continued the class to the best of my ability, after the Bible-class on the Friday afternoons. It proved a great attraction, as many as from two hundred to two hundred and fifty attending. The Malagasy are fond of singing, and they sing remarkably well, considering the very small amount of training they have had.

Their beautiful language also lends itself readily to music. Malagasy abounds in vowel sounds and in liquid consonants. Its soft and musical flow has earned for it the name of the Italian of the southern hemisphere. It well deserves the name. It was refreshing to see and hear two hundred, from lisping childhood to grey old age, singing with heart and voice: "There is a happy land,' 'Oh, that will be joyful,' 'Rock of Ages,' 'Jesus, the Good Shepherd,' and other well-known hymns.

At one of these singing-classes, at which we had been practising some new hymns, I asked Razàka how he liked the new hymns. 'I like them all very well,' but, 


\section{Development and Consolidation}

he added-the tears meantime flowing down his furrowed cheeks-'I like best, "Rock of Ages, cleft for me."' 'Yes,' I thought, ' that's the truth that touches the hearts of all God's people of whatever clime or colour. That has the kernel of the Gospel.'

All the things that go in pairs in Madagascar are called mivàdy, i. e. mated, matched, married-literally, husband and wife. Thus a pair of gloves are mivàdy, the same with a pair of socks, or boots, or shoes. The idea is that of completion. The one is regarded as the complement of the other. The same idea was applied by our people to a hymn and its tune. They were mivàdy-united, mated, married. The hymn was regarded as the husband, and the tune as its vaddy, wife. Every hymn must have its own tune, its own vàdy, wife, and our people would not allow of their separation, their 'divorce,' as they called it. I did not know of this idea of theirs for years, and cannot say whether the natives in other parts of the island hold the same view of the matter; but our people in Vònizòngo certainly did. I found this out at one of our singing-classes.

There was a new missionary hymn, a free adaptation of ' From Greenland's icy mountains,' which I wanted them to learn to sing, as I wanted it sung at the opening of our new church. 'Now,' I said, 'I want you to learn to sing this hymn, as it is a very good one, and the author is coming to preach at the opening services, and I am sure he will be pleased to hear his hymn well sung.' On this I started off singing the hymn to the tune 'Missionary'; but no one joined in. I stopped and asked: 'Why are you not joining in the singing?' They answered: 'That won't do, sir.' 'Why won't it do?' I asked. They said: 'Sir, that can't be the proper tune for that hymn for that is the $v a d y$, wife of another hymn.' They had married 


\section{Seeking a Hymn-wife}

that tune to an adaptation of the English hymn, 'Go when the morning shineth.' 'They felt that it would be improper to separate this well mated and harmonious husband and wife! They demanded consistency on my part. 'You often tell us,' they said, 'that divorcing is wrong, and yet here you yourself want to divorce $i z y$ mivaddy,' these united ones. 'But,' I said, ' that's carrying the idea as to divorce to absurdity. Why, the hymn suffers nothing by the separation, nor does the tune.' They said: 'It would not be right, sir, and we don't like the idea of separating them.' 'Why,' I said, 'over on the other side of the ocean, we have one tune to serve a dozen of hymns, and one hymn to a dozen different tunes.' They answered: 'You white people may do as you please on the other side of the ocean, but we don't like such doings. We regard it as culpable divorce, and altogether wrong.' I asked: 'Do you really mean all this in sober earnest?' 'Yes, sir,' they answered. 'Well,' I said, 'I don't want to hurt your feelings of propriety, or force you to do what you think wrong; but I am sorry, as I wanted this hymn sung at the opening services.' 'So you can, sir,' they said, ' if you wish it.' 'How can I?' I asked. They answered: 'Seek a vàdy for it.' 'Where could I get a tune for it?' I said, 'I am afraid I don't know enough about music to be able to set a tune to a hymn, even if I found one.' They replied: ' Oh yes, sir, if you set yourself to it, you would manage, somehow, and with that we passed on to the singing of another hymn.

The following Friday forenoon, while preparing for the Bible-class, there flashed into my mind a tune I had heard in Edinburgh eight years before. It sounded as if it might be a suitable vàdy for the hymn; for I had tried some of the old Scotch psalm-tunes in vain. There was 


\section{Development and Consolidation}

no marriage likeness between them and the hymn, and till the echo of this tune from the solitary cornopean player on an Edinburgh street came up, match-making did not seem my forte. I do not remember that tune ever entering my head again from that day, when first heard in 1868 , till it flashed into my mind that forenoon in 1876 . John Wesley is credited with saying, that it was not fair to let the devil have all the best of the tunes. I tried the hymn and the tune over, and it was quite evident that that tune had been intended as the vàdy for that hymn, although, perhaps, the composer did not know what he was doing when he produced it. The ' marriage likeness' was so clear, that I proclaimed the banns and united them there and then. I sung the hymn, set to the new tune, to the class in the afternoon. 'That's it, sir,' they said. 'We knew you could find a vàdy for that hymn, if you only set your wits to work.'

At the opening services, the hymn was sung so well and heartily that the author said to me, on our way home to the manse after the service: 'How well and heartily your people sing that hymn of mine!' 'Yes,' I said, 'they sing it very well, don't they?' He said: 'I never heard it sung better, but what tune is that you sing it to, and who set it to that tune ?' I answered 'I had.' 'What tune is it ?' he asked. I said, 'Don't you know it ?' 'Yes,' he said, 'I do, and yet I can't name it.' I said: 'It's "God bless the Prince of Wales." ' 'Of course it is,' he said; 'but how did you come to set it to that tune? We sing it to "Missionary" in the capital.' I said, 'We have another vàdy for that tune here in Vònizòngo,' and then I told him the whole story, and found that the idea was as new to him as it had been to me.

The Rev. W. E. Cousins told in 1877 the following rather amusing incident with regard to the advent of that 


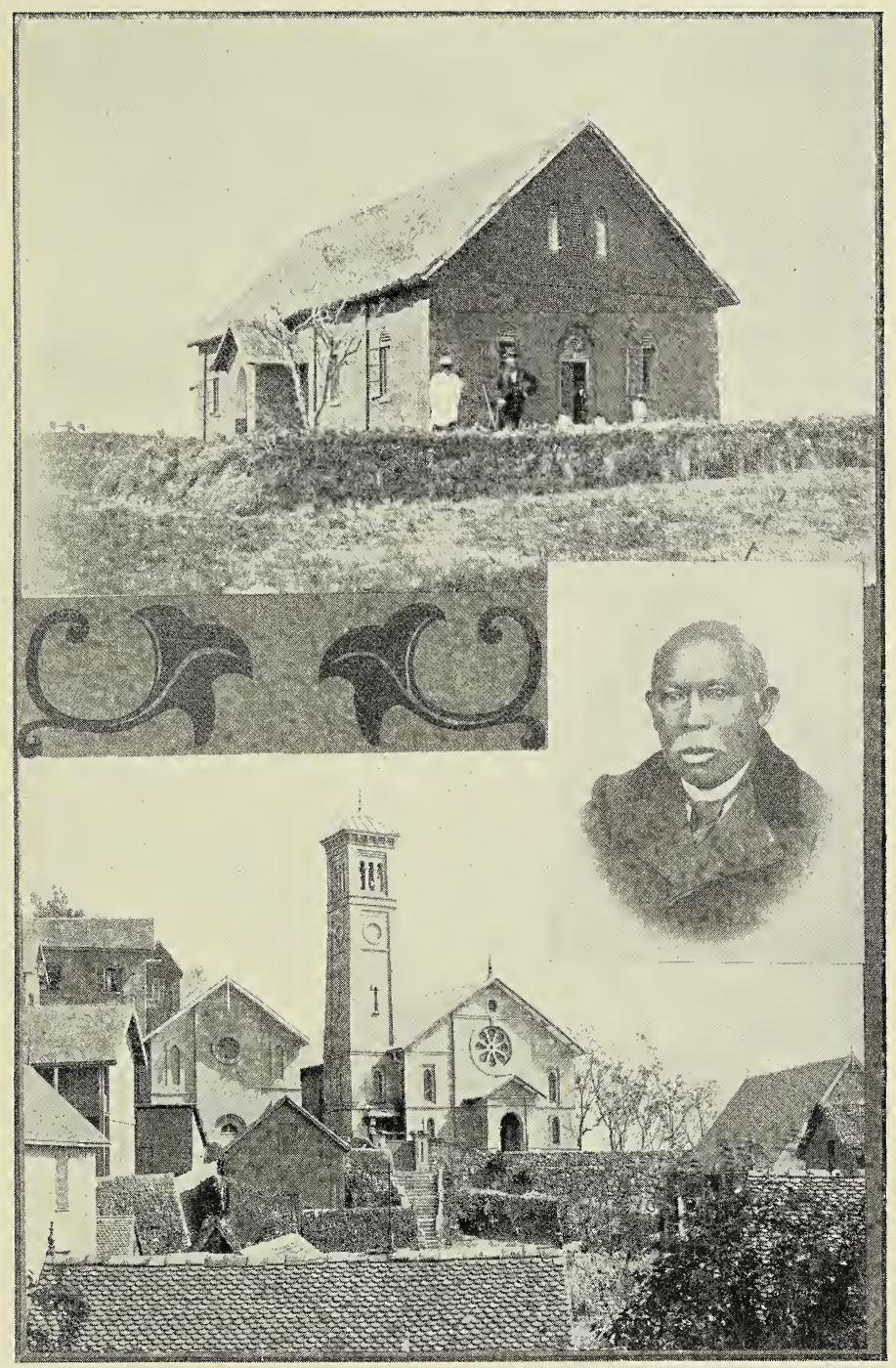

MARTYRS' MEMORIAL CHURCH, FIHAONANA.

THE SPURGEON OF MADAGASCAR.

MARTYRS' MEMORIAL CHURCH, AMPAMARINANA. 



\section{A Suspicious Hymn}

hymn in Antanànarivo. He said: 'Mutual confidence is a thing scarcely known yet in Madagascar, not known at all, perhaps, apart from the influence of the Gospel, and now and then these suspicious people see danger threatening their commonwealth in little suspected quarters. Quite recently a hymn was published. It is our Malagasy representative of "From Greenland's icy mountains." The first verse might be translated as follows :

Oh, speed Thee, gracious Sovereign,

Set up Thy rightful throne;

$\mathrm{Oh}$, hasten, Lord, and take Thee,

The land to be Thine own.

All very simple to us, but to the Malagasy, the gracious Sovereign was none other than Queen Victoria. Her rightful throne was to be set up in Antanànarìvo; and we were asking Queen Victoria to come and take Madagascar to be her own! You see, they read between the lines, and saw meanings that were never intended. The hymn had to be disused for several weeks in consequence of this wide-spread suspicion.'

The event of that year was the opening of our new church at Fìhàonana, the Martyr Memorial church, at the home of the martyrs, where they lived and taught, and among whose rocks, ravines, and caves they hid themselves and the word of God during 'the killing times.'

We had good opening services, and our people were delighted with them, as also with the number who came from the capital to attend them. We had twelve members of the mission present, three of the chief pastors, who were also royal chaplains, while Her Majesty sent $£$ ro, equivalent to $£_{50}$, to the building fund! Fìhànana was quite a scene of excitement, and all the houses and huts were full of visitors from all parts of our own and other 
districts, and from the capital, as were also the houses and huts in all the neighbouring villages. We had a special prayer meeting on the Saturday evening, as a finish to our work of preparation for the opening services, and to invoke a blessing on them.

By five o'clock on the Sabbath morning our people were waiting at the church doors to get in, and hours before the time of service, the church was crammed in every corner, while hundreds stood outside, listening at the open doors and windows. The morning service was from nine to twelve o'clock, and the afternoon from two to five. We had service again on the Monday forenoon. We had six sermons at the services, one each from the three pastors from the capital, and the same from three members of our mission. In them our people had a feast, especially in the magnificent sermon of J. Andrianaivo, 'The Spurgeon of Madagascar,' and in the marvellous oration of Rainimànga, the ex-slave, one of the orators of the island.

After the service on Monday forenoon we adjourned outside, when Hàsina (the unbroken money tendered to Her Majesty's representatives at all great gatherings, in token of allegiance) was presented, and we received the $£$ Io sent by the queen to the building fund. Matiosy Mivàdy, Matthews, husband and wife, were publicly and profusely thanked in the name of the queen and the prime minister-much to the joy of our people-for all they had done and were doing for the good of the people of Vònizòngo. As I had to respond to that, I simply said we were only doing and had done what we intended when we came to the island, namely, our best and utmost for the good of the people, and the spread of the Gospel: and we purposed continuing in the future to do as we had done in the past. 


\section{A Church Opening}

The queen's message with regard to education was then given, which flatly contradicted all the false reports that the old heathen party had set in circulation to the effect that Her Majesty had no longer any love or respect for religion, that she was about to put a stop to public worship, close all the schools, and had forbidden the people to pay any salary to the schoolmasters.

We then expected the bullock to be presented to the queen's messengers and the pastors from the capital; but it had been stolen during the night by an uninvited official-one of the judges-who had turned up, and sent it off by one of his slaves at daylight to the capital to be sold there! I did not know all this till a fortnight afterwards.

As there was no bullock and none to be had (although there might have been, had the poor people had money with which to buy another one), the visitors had to be fed on pork, at which they were very displeased, and little wonder, thinking that Razàka, the chiefs, and our people were a very mean set of folks not to have provided a bullock for them.

Many years after, one of the city pastors present at the opening services, in speaking of them to me, brought the charge of meanness against Razàka, the chiefs, and the people of Fihàonana because of the treatment they had received on that occasion, and I had to tell him, much to his astonishment, how it was that they were treated as they were, and had no bullock presented.

About a fortnight before the date we had originally fixed for the opening of our new church, we found we should have to take down the south gable, as it had been built off the plumb, while we were away on our holiday. A hurricane had so shaken the roof that we found the gable was giving, and would have to be taken down and 


\section{Development and Consolidation}

rebuilt. We put off the opening services for a month. We took off a third part of the roof, took down the gable, made 40,000 bricks, put it up again, plastered it outside and in, whitewashed the inside, reroofed the part we had removed, and did all in five weeks. Nearly all the work was done by our own people, who in addition provided all the material, while an entire set of new mats for the floor was provided by the women.

Our people came out very clean and tidy for the opening services, and some of them 'braw' even. Their singing was very much admired; for although we had no ' kist o' whistles' to lead the singing, as our people made good use of the organs God had given them our singing was always hearty, and if not always quite as correct and harmonious as it might have been, there was always soul in it, and all joined in the service of song.

Our friend, the late Joseph Sewell, of the Friends' Mission, came to see us that year, and to spend a few days at our station previous to his retirement from the Madagascar Mission. He took my Saturday morning class for pastors and local preachers; and had a long talk with them on the subject of slavery, a subject on which 'Friends ' have always been 'sound.' The following Saturday morning, as I also wished to have a talk with them on the same subject, I asked what Mr. Sewell had been talking to them about the previous Saturday morning, and they answered, 'Slavery.' 'Well,' I said, ' and what is your opinion of what he had to say on that subject?' 'Well, sir,' they said, 'we cannot see slavery in the light that you white men see it.' 'No,' I said, 'I don't suppose you can, or you would have done with it at once.'

As I wished to present slavery to them in the strongest 
and most repulsive light I could, I asked them: 'Supposing Jesus Christ were in the market on sale for thirty dollars_-"thirty pieces of silver"-would you buy Him?" 'No, sir,' they answered; ' how can you ask such a question?' I replied that I had a purpose in asking it, and said again: 'Suppose He were in your possession as a slave, would you sell Him for thirty dollars?' 'No,' they said, 'most certainly not, that would be as bad as Judas Iscariot.' ' 'Well,' I said, ' perhaps it would, I just wanted to know your opinion on the point. Then you would neither buy Him nor sell Him, even if you could,' I said. 'Most certainly not,' they all answered. 'Well,' I continued, 'we have a good many church members here at Fìhàonana who are slaves; now if they are true members of the church, they are members of the mystical body of our Lord Jesus Christ, are they not, and sons and daughters of the Lord Almighty?' 'Yes,' they answered, 'that is quite correct.' 'Well,' I added, 'do you remember reading, or hearing read from the New Testament, that one day, while Jesus Christ was teaching, His mother and His brethren came and wished to speak with Him, and some one told Him, when He said: "Who is My mother, and who are My brethren? Those who do the will of My Father Who is in Heaven."' They said they remembered the incident. 'Well,' I continued, ' while it is quite true, and never to be forgotten, that Jesus Christ was and is the Son of God in a sense that no created being can ever be, still, if those slaves who are members of the church are true members, they are sons and daughters of the Lord Almighty, and brothers and sisters of the Lord Jesus, by His own showing; so that while you keep on buying and selling them, you are really buying and selling the sons and daughters of God, and the brothers and sisters of the Son of God, and 


\section{Development and Consolidation}

it seems to me to be going but one step further to sell Himself!'

'Well, sir,' they said, 'we certainly never saw it in that light; for it was never put to us in that way before.' 'Well, but,' I added, 'don't you see and admit, that it may be looked at in this way?' They answered that they did, and then there was silence for some time, which was broken by one of them asking: 'Well, sir, how would this do? Set all the children of God free; but the children of the devil, keep them in slavery as long as they live!'

'Well,' I answered, 'by that plan you would get rid of the difficulty and be clear of the guilt of buying and selling the sons and daughters of the Almighty, and the brothers and sisters of His Son; but don't you see, that you would not get rid of all the difficulties even by that plan, in fact, you would only remove them a step. You remember God said: "Let Us make man in Our own image after Our likeness ... So God created man in His own image, in the image of God created He him; male and female created He them." And so you see, you would not quite get rid of all the difficulties, as you would still be buying and selling men and women created in the image of God, and also desecrating that humanity which has been sanctified by the Son of God tabernacling in it.'

'It's of very little use,' they said, 'arguing with you white men on the subject of slavery. You have always an answer ready for everything we may advance in support of it, and we always get the worst of the argument; and so we may just as well give in now; for we are certain to be beaten in the end.' 'You have a very bad cause to defend,' I said, ' and although " Good men may be connected with a bad cause, good men can never 
make a bad cause good." Your cause is thoroughly bad. It is rotten to the core, and the sooner you cut all connexion with slavery - as you will have to do some day-the better it will be for yourselves and everybody else.' 'Well, sir,' they said, ' that may be quite true, but it will require a great deal of the grace of God to enable us to see slavery in the light that you white men see it, and cut all connexion with it.' 'Very likely, I answered: 'for it took a great deal of the grace of God to enable our forefathers to see slavery in its true light.'

The state of the churches that year, and the causes which affected them, had also a detrimental effect on the schools; for with the exception of the four schools connected with the four principal churches and a few others, the majority had made but little progress, as we found at the annual examination. The four schools mentioned had trained teachers, who had not been disturbed in their work; whereas other schools had poor teachers, who had been very much disturbed, and hence had got very little teaching done. Still, at the annual examination, I was surprised with the progress that had been made, notwithstanding all hindrances; and especially with the work done in the four principal schools. Whereever I went to preach, I made a point of catechizing the children for an hour the first thing on Sabbath mornings. There were many and great advantages in following this plan. It not only benefited the children, but the adults also. They heard the questions, the answers, and the explanations; and learned something in spite of themselves.

It was very cheering and refreshing to find that the schools had made such progress, especially in Bible knowledge. I had sent six of my best lads to the 


\section{Development and Consolidation}

normal school at the capital for two years' training; and as that class of teachers increased our schools improved. For trained teachers our people were quite prepared to pay, when they would not pay for trained evangelists. They could see sooner the results of the teachers' work in the progress of their children than discern improvements in themselves.

Except here and there, at advanced central stations, trained evangelists were not needed, and the people would not pay for their services. Their own pastors and local preachers were quite equal to the spiritual and intellectual wants of their churches. These country pastors were rapidly improving in knowledge of all kinds, by their attendance at the Bible-classes, by reading the Monthly, and commentaries. They got no salary, so that even the poorest churches could avail themselves of their services. The great want was trained godly teachers; for our hopes for the future of the churches, the district, and the country were based upon the work of the schools, more than even on the churches themselves.

At the examination at the beginning of the year, I had picked out forty of the most advanced lads from the various schools in the district, got them freed from government service, and brought to Fihàonana to be prepared for the entrance examination of the Normal school. Fourteen of these passed. At the spring examination I picked out other fourteen for preparation, so that I had sixty lads under training to be teachers, forty at Fìànana, and twenty at the Normal school.

Our station school at Fihàonana had kept up well puring the year. Till June we had a daily attendance of from two hundred to two hundred and twenty, exclusive 



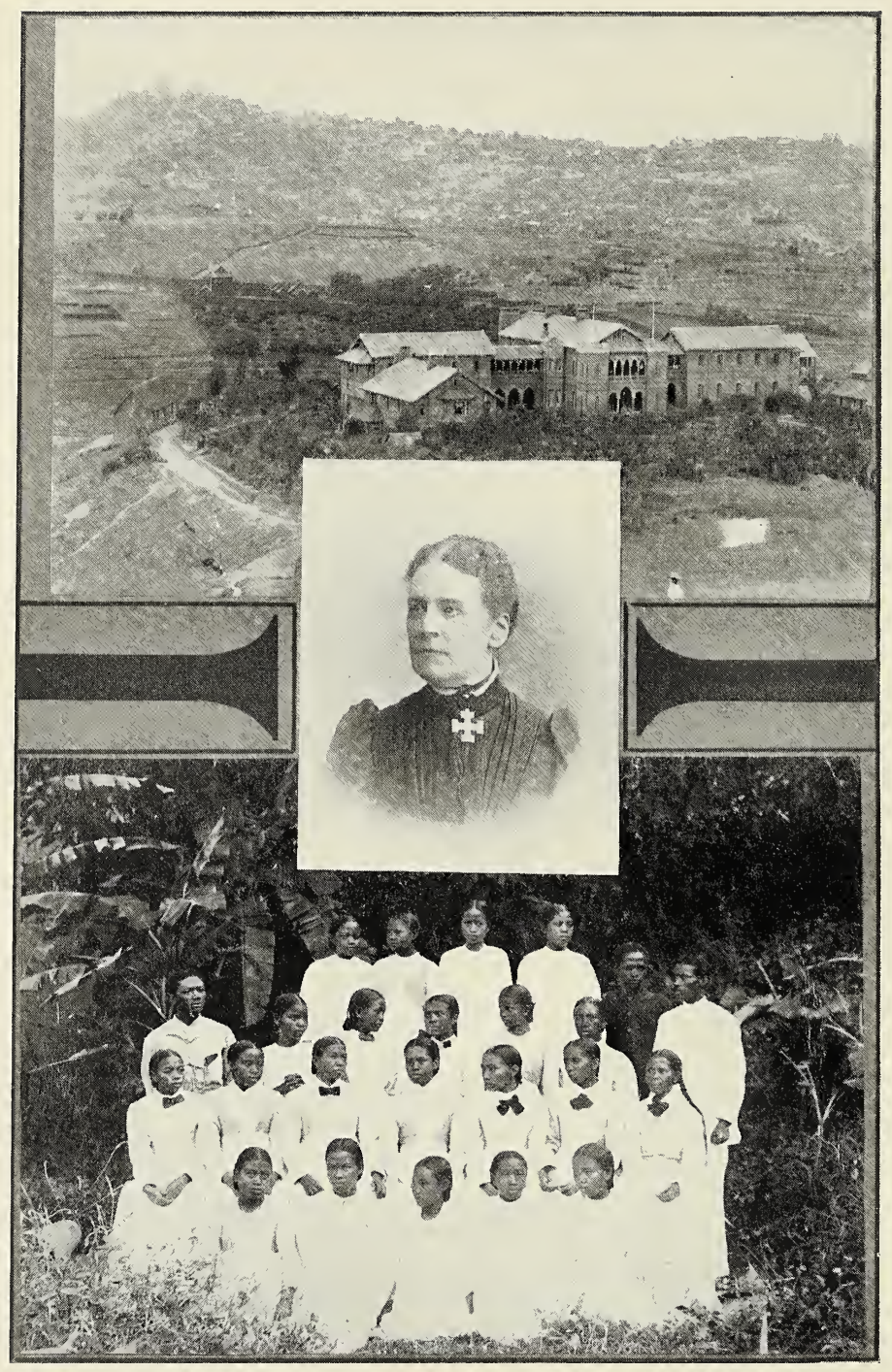

THE MISSION HOSPITAL.

MISS BYAM, THE MATRON.

A GROUP OF NURSES. 
of the forty lads under special preparation; but the stupid excitement on the subject of slavery led to many of the slave children being removed, so that the school fell for a time to one hundred and eighty. We soon got it up to former numbers, however, by an influx of new scholars. Our school cost us $E_{\mathrm{I}}$ I $7 s$. od., equivalent to $£_{9} 5 s$. od., a month, which was a large sum for even a station school; but it was the largest station school in the island then. By the examination returns we found that we had 80 who could read, 67 from the Gospels; 96 had slates, 65 could write on them, and 57 could do some arithmetic, while two years before there was only a school of 30 , not 20 of whom could read, or write, or had Bibles, Testaments, or slates; so that considerable progress had been made, an earnest of what was afterwards to be. The false reports set in circulation by the old heathen party, that there was to be no more praying allowed, affected the sale of books very much; still, we sold 300 Testaments, 50 Bibles, 600 catechisms, 1,000 school slates, and many hundred lesson-books, hymn-books, and arithmetics, \&c., besides 300 Good Words monthly.

I was very deeply disappointed with the reception that my two trained nurses met with for some months after their return from the hospital at the capital. No one would have them, because 'they followed the white people's mode of treatment'; and when some cases turned out badly under the insane old heathen methods, and our nurses were sent for I declined to let them go. This brought a good many to their senses. Unless our nurses were called in at first, they were not permitted to attend. This brought the more sensible to see things in a proper light. 'The tide soon turned in the nurses' favour, and their services were appreciated, paid for, and 


\section{Development and Consolidation}

greatly in request. The old heathen ideas as to medicine, nursing, and general treatment of the sick rapidly died out in the neighbourhood, while ours as rapidly gained ground.

With the exception of superintending the girls' school and taking the sewing-classes for two hours a week, my wife had neither time nor strength for doing more that year; but her labours in that direction were much appreciated, and there was always a larger attendance at school on the days of the sewing-class. We had a very handsome subscription to the building fund of the new church from the sale of the work of the girls at the sewing-classes.

That year marked, very decidedly, the rapid passing away of old things, external and internal. Old heathen ways of doing and looking at things changed. The leaven had been put into the meal, and was rapidly working its way to the surface, affecting everything and everybody, and all the ways and walks of life.

The damp floor of our new church, and the dayschool being taught in it, soon destroyed the fine set of mats prepared by the women for the opening services. They had rotted away and were soon in shreds. As the women could not be expected to provide new mats every few months, or the congregation to buy them, something had to be done, and I was greatly exercised in mind to know what to do to get a dry floor. I could not lay down a wooden floor, that would have cost $£$ roo. As I had no $£ \mathrm{roo}$, and was weary of begging, I had to set my wits to work to find out how a dry floor could be secured. After some time I came to the conclusion that the best thing would be to macadamize it.

I went down to the school next morning, to enlist the services of the children. I said to them: 'I want 


\section{Youthful Floor-makers}

you to help me to floor the church.' They looked at me and then at each other, not seeming to understand what I meant, and, perhaps, suspecting that I had gone slightly wrong in my head. I said: "We white men have a proverb which says: 'Foolish people and children should never see half-finished work.' You just do as I tell you, and you will find that it will be all right in the end. Every morning as you come to school, bring a stone in each hand, about the size of your fist, and fling them down at the church door.' They did so for several months, and I went down one morning, and we flung all they had brought into one corner of the church; but they only filled a space of about twelve feet square and a foot deep. 'Well,' I said, 'children, it will evidently take us a very long time to floor the church at this rate; suppose we set to work and finish it off at once.' 'Just as you please, sir,' they said. 'Well,' I said, 'you shall have a holiday to-day; but come at the usual hour to-morrow morning.' They were all there at 8 o'clock next morning, and so was I, and after the hymn, reading of the Scriptures, and prayer, we started off to gather stones till I2 o'clock, and we kept at that, all over the moor from 8.30 till 12 o'clock for five days a week for over a fortnight. We filled the floor of the church, a space of 60 feet by 40 . I. got the women folks to bring me sand from the banks of the stream, and spread a few inches of sand over the stones. What was then wanted was a roller, but there was no such thing to be had. 'Take what you have and you'll never want' came in useful again. I had no roller, but I had 260 children with a couple of feet each, and I set them scampering and dancing all over that floor, until they had tramped it as hard as any roller could have made it. I then had three inches of mud spread above 


\section{Development and Consolidation}

the sand, and the whole floor washed with odorous waters, which, repeated at intervals, kept the floor unbroken, and gave freedom from the insect pest of Malagasy churches, and thus we got a clean, dry, comfortable floor, which had not cost money, and all felt that they had done their share in the producing of it-a most important item.

The walls of our new church had been nicely coloured and ornamented by means of stencil plates; but as we had to conduct a large day-school in it, the walls got soiled and suffered in other ways. We found, to our surprise, that there were a great number of budding artists among our boys, and they would persist in exercising their gifts on the walls, until our people became quite angry over their doings. They said: "We cannot allow the walls of God's house to be desecrated in that way. If those boys won't desist, we shall turn them out of the church to learn outside.' 'Yes,' I said, 'It is very thoughtless of them; but you "can't put old heads on young shoulders," and boys will be boys, the fact is, I was once a boy myself. There is nothing for it but to build a large school-house, and get them out of the church.' 'Oh,' they said, 'but that is building again, and we are tired of building.' 'Well,' I said, 'If you are tired of it, what do you think I am? What's to be gained by falling out with the indications of Providence? Sit down and let us discuss the situation'; that is what the Malagasy enjoy.

We sat down and discussed the matter for two hours, until every one had his say-some several times over. After we had gone over all the pros and cons, I said: 'Now to bring things to a point, you will make the bricks for the new school, the children will carry them to the site, and I will pay for the laying of them. The 
women will gather the thatch for the roof, you will thatch it, and I will be responsible for all the woodwork-the roof, the doors, the windows, and the glazing. 'That's it, sir,' they said, and we all set to work with a will, and our fine large school was soon an accomplished fact.

The people fulfilled their part of the agreement with great heartiness. In fact, after I declined to leave them and go to Mojangà, to open a new mission on the north-west coast, they were most diligent; I had only to mention what I wanted done, and it was done at once. The men made 200,000 bricks, the school children carried them to the site, the women gathered roo bundles of thatch, and the men thatched the building. The glass for the school, and also for three churches in the district, was a gift from my old friend Colonel R. Pilkington, M.P., of St. Helen's. It was a fine school, a fit addition to our model church. It was of immense service for years. It was requisitioned during the reign of martial law, after the arrival of the French, and since r 897 there has been a large government High School for boys conducted in it. Compensation was paid for the other buildings requisitioned; but nothing has ever been obtained for it, for the remains of the manse, or for the yard for which we had a forty years' lease.

While buildings were being erected, and the schools were being carried on, the churches of the district kept gradually increasing in number, and were being consolidated, as the people grew in knowledge, in the fear of God and in Christian liberality. The darkness and ignorance of their former benighted state gradually gave way before the rays of the rising sun of righteousness; and the light of the knowledge of the glory of God, as it shone ever clearer in the face of Jesus Christ. Hence 
there was a growing anxiety for instruction-especially religious instruction-as they came to understand more clearly what church membership and a profession of Christianity meant.

Of course such things could only be said of the members of the more advanced and intelligent churches; for, as might have been expected, from their very recent state, there was a want of reality among many. Much of their religion consisted of attendance at church on the Sabbath. They showed but slender signs of Christian life, if ever they had tasted that the Lord is gracious. We were convinced of the truth that 'The soul of all reformation is the reformation of the soul.' Until that takes place, there is nothing that can be depended upon. We have, however, thankfully to acknowledge that hundreds madereally most praiseworthy efforts towards higher and better things. Remembering how handicapped many of them were by their past habits and heathen surroundings, their progress was most creditable.

There were many indications of improvement and progress that could not always be tabulated, or reported, such as: the gradual but most decided improvement in the social condition of the people, and especially in their view of the marriage relation. More attention was also devoted to personal cleanliness, comfort, and decency in clothing. There was still a love for finery, and a weakness for gaudy colours among the women folk; but even they showed signs of an improvement in taste. Many huts, which had been little better than filthy pigstyes seven years before, became clean, tidy, decent, and comfortable. This led to an improvement in health and morals; for you cannot have anywhere dirty overcrowded homes and good morals any more than good health. Prayer and praise began 



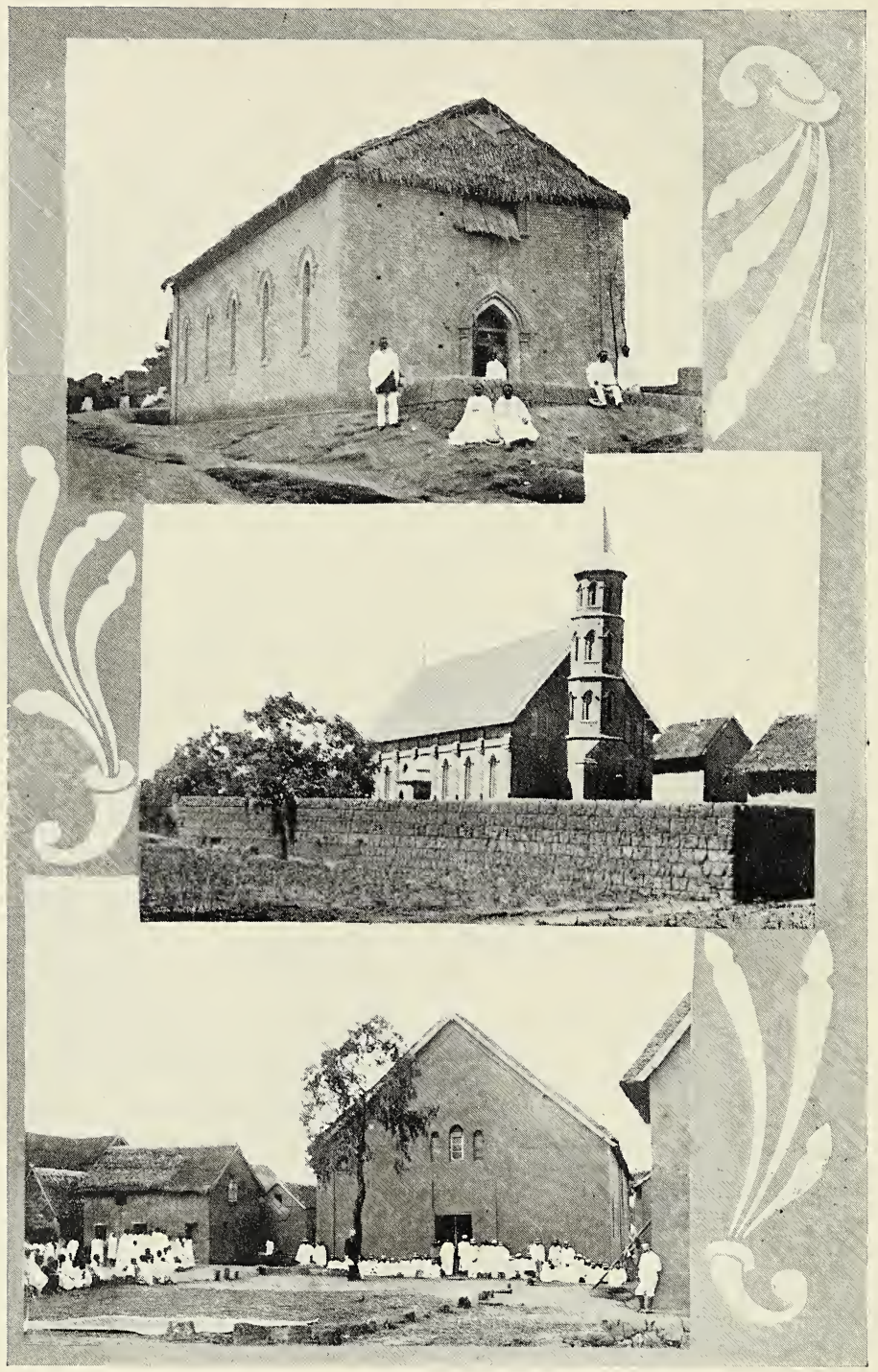

SUBURBAN CHURCH, OLD STYLE. SUBURBAN CHURCH, NEW STYLE. IMERIMANDROSO CHURCH. 


\section{Healthy, Happy Firesides}

to rise from firesides, amòrom-pàtana-formerly given over to heathen folk-lore and filthy communications. Bible-reading took the place of story-telling and gossip. Health so far improved that in our village of Fìhàonana, and a few near, with the exception of mild attacks of malarial fever, sickness so decreased that I had not one patient where formerly I had ten. Typhoid fever, which had been the plague of the place, and which, had they followed my advice to the full, I believe we could have stamped out, or nearly so, was greatly diminished.

With the improvement in the huts and homes, there was also an improvement in the church buildings. The large mud huts were replaced by handsome brick buildings, with platform pulpits, and, in a few cases, with tiled roofs and glazed windows. 


\section{CHAPTER X}

\section{THE DEAD PAST}

'All the earth shall be filled with the glory of the Lord.'

NUMBERS xiv. 21 .

IN former times the Malagasy used to hold great feasts, rum-drinking and horrible orgies at the funerals of all people of any consequence. The corpse was rolled in a silk làmba, while all clothes, dresses, and jewellery belonging to the deceased were placed in the family or royal tomb, as the case might be, along with the corpse. I remember the death of a very old and famous chief, 'the head of the black people.' It was stated that his corpse was rolled in eighty-four silk làmba! It was also the custom to fill the mouth of the corpse with cut money-silver cut up to the size of broken rice. If the deceased had been fond of rum during his or her lifetime, water-pots filled with it were placed in the tomb!

The Malagasy of Central Madagascar had been in the habit for ages of opening the tombs of their ancestors at stated periods, removing the rotten làmba, and rolling the bones in new làmba. To purchase the new làmba a levy was made on the descendants and clansmen of the deceased. Even the slaves of the various families were expccted to contribute to $N y$ mamàdika ny màty, i. e. ' the turning of the dead,' which were often occasions for great gatherings at which there were feasting and drinking, music and dancing, for which bands of musicians and female singers-both being generally of the 


\section{Degrading Burial Customs}

lowest and most abandoned of the community-were hired, and heathen orgies and hideous debauchery were the order of the days and of the nights.

After the general acceptance of Christianity in the central provinces, there were often religious, or semireligious, services and often preachings at those gatherings; but, as the after conduct of many was hardly consistent with such religious exercises, we were compelled to decline countenancing them and now they have almost died out or been put a stop to.

Such were some of the customs of former times connected with the burial and turning of the dead, and probably similar customs are still rife in those parts of the island on which the new light has not yet dawned-two-thirds of the island being still in heathen darkness. About a million, perhaps, of the people of the central provinces have been reached in some way, and some at a few points on the coast; but the rest-some three millions-are still in a state of heathenism. There murder, infanticide, slavery, drunkenness, polygamy, obscenity, war and all the other horrors of heathenism and degradation are rampant.

But on the other hand, to show the change that was coming over the people as to their views of death and their burial customs, I may mention that the first legacy was left to the church during that year by the wife of a petty chief, who was one of our village pastors. I was invited to preach at her funeral, which was conducted in a quiet, decent, and most orderly manner. There was no feasting, drinking, music nor dancing, and her money was left to the church instead of being buried with her corpse.

Our good Christian queen gave an example during that year of her desire to be a nursing-mother to the 
church. An officer of high rank in the native army, who had been married for some years to a woman of lower social rank than himself, divorced her as she had no family by him. As he was a member of the church in his native village he was first remonstrated with, and then suspended from church fellowship for divorcing his wife without proper cause. Being a person of some consequence in his own village, he resented being excommunicated and, in a measure, disgraced in the eyes of his relations and fellow villagers; but as the church refused to readmit him, unless he took back his wife, he began in various ways to persecute the pastor, office-bearers, and members of the village church. It was a 'child,' that is, connected with and under the care of the mother-church of Ampàribè in the capital.

One of the pastors of Ampàribè was also one of the queen's chaplains. The village pastor had complained to him of the treatment he and his people had received at the hands of the officer for doing their duty. One day, while conversing with the queen about the progress of the churches, he told her about the faithful little village church and the conduct of this officer. The queen summoned all the parties before her, heard all that had taken place, and asked the officer if the statements made were correct, and he had to admit that they were. She ordered him to take back his wife, and for persecuting the pastor and church for doing their duty she disgraced him, took away all his honours and reduced him to the ranks. The queen then turned to the pastor and office-bearers of the church and thanked them for so courageously doing their duty, and said: - Remember that in the Church of Jesus Christ we are all equal. I am the same as a slave woman there!' That was a most extraordinary statement for her to 
make. Twenty years before, such a statement might have cost her her crown, if not her life.

On one occasion a woman appealed to the queen to be separated from her husband, to whom she had taken a great dislike. She said that she hated him and could not live with him, and did not wish to see his face again as long as he lived. Her Majesty ordered her to be brought before her, and inquired fully into her case. She asked if the husband was a bad man, or if he used her badly. The woman said 'No.' But when asked why she wished to be separated from him she could give no reason, except that she had taken such a great dislike to him that she could no longer live with him. After hearing all the woman had to say, Her Majesty replied that all she wished could be very easily accomplished, and the woman was accordingly jubilant. The queen summoned an officer, to whom she said: "This woman has appealed to me to be separated from her husband, whom she says that she hates, and that she does not want to see his face again. Now you take charge of her, take her to Fort Dauphin (at the extreme south of the island, five hundred miles from the capital), where she is to live for the rest of her life, and so make certain that she never sees again the husband whom she hates so much.'

The woman was speechless for a few moments, but, when she had recovered herself, and fully realized what the queen's orders involved, she fell on her knees crying for mercy, hugged and kissed Her Majesty's feet, promising to return at once to her husband, to be a good and faithful wife to him, and never again to say that she hated him. The queen, however, paid no attention to her appeals; so the officer came forward and laid hold of her to lead her away; thereupon she 
fairly became frantic, screamed with terror, clung to the royal feet, and pleaded in such agony for mercy that the queen, seeing that she had most thoroughly frightened her, extended mercy to her, revoked her order, and sent the officer home with her to her husband with instructions that he was to treat her kindly.

I was six years in Madagascar before $I$ had to perform the marriage ceremony for any of our people. We found the vast majority of the church members and adherents married, and those of the latter who were not could not be persuaded to follow the Christian mode of marriage. They said our agreement was too hard, it was till death. We might take our wives till death, as they were wise and good; but as their women were foolish and bad, they could not consent to take them until death. Their view of marriage was that of their own proverb which says that marriage is like marketing -if the parties don't agree they simply separate.

At last one of my deacons, who was a widower, wished to marry again, and he asked me to perform the marriage ceremony. We had the marriage in the station church one Sabbath morning at the close of the service. The deacon and his bride stood up in front of the rail, and I began reading the marriage service. At one part of it I had to ask the usual question-Efa làsa va my vòdiondry? i. e. 'Has the sheep's rump gone?'

In former times quarrels seem to have been made up, and serious agreements concluded over the carcase of a slain animal, after which a feast followed (Gen. xxxi. 44-55). Perhaps the marriage agreement was made or concluded over the carcase of a sheep, after which the hinder quarters may have been handed over to the father and mother of the bride, or her guardians, and the 
reception by them of $n y$ vodiondry in the presence of witnesses made the marriage legal. It afterwards came about that a small piece of money took the place of the hinder quarters of the sheep ; but that still retained the name of ny vodiondry, 'the sheep's rump,' and the reception of that by the father and mother of the bride, or by her guardians, constituted the marriage legal. Not that there was much in the legality; for a man might divorce his wife at any time by simply saying to her, 'Thanks, go!' She could not divorce him, but he could divorce her at any time. We had to ask, therefore, while reading the marriage service, if the legal transaction had taken place, because if not we could not go on with the service till it had.

My wife had never read the Malagasy marriage service, I don't think she even knew about the vodiondry; certainly she did not know that we had to ask in the marriage service if that had gone or been received; and hence, when I called out in the middle of the service, 'Has the sheep's rump gone?' the look of surprise and horror which came over her face was a thing to be remembered. I suspect she feared I had taken leave of my senses.

During the previous year our station church had given a salary of $£_{5}$ to their good old pastor Razàka, who, up till then, had not received any salary, although he had laboured ' in season and out of season' for twenty years for the church and district; but, during 1878 , they agreed to give their second pastor $£ 28 s$. a year, and an evangelist also $£_{2} 8 s$. They paid the teachers of the Congregational school $£_{7} 4 s$. a year, gave $£^{2}$ to the Native Missionary Society, besides congregational expenses, which would probably be $£_{2}$. In all this amounted to $£ 2 \mathrm{I}$-but it was to them then what $£$ IO 5 would have been to us. This was from a poor 
village church of ninety-six members, a third of whom were slaves!

The year 1879 was most disastrous to all branches of the work, for the central provinces, and Vònizòngo in particular, were visited by another epidemic of malarial fever, which was much more severe than that of the previous year. The former had probably carried off 5,000 people, yet it was mild when compared with what we had in 1879 . We ourselves also suffered much more severely than we had done in the previous year-partly because we were both very much exhausted by eight years' very hard work in one of the worst fever districts of the island. For, notwithstanding all the precautions and care that we took, I was prostrated eleven times with fever, and my wife seven times, and some of our children about a dozen times, although during twelve months we had used nearly two ounces of quinine, to which, under God, I believe that we owed our lives.

Towards the end of the previous year I had again brought under the notice of our churches the subject of teaching our adherents to read. The matter was taken up very heartily by our station church, and afterwards by the various churches in the district. They also entered into the plans with great heartiness, and the result was that in a short time a large number of the churches were at work. We arranged that the church members who could read should form evening classes in their own villages to teach the adherents who could not. They were very much assisted in many villages by the elder scholars from the village school, and in the course of a few weeks we had 2,000 adults gathered into evening classes learning to read! Alphabet sheets, to the value of $£ \mathrm{I}$, were given to them, and they themselves spent $£_{7}$ on first lesson books! The news of what we were 


\section{Transition State}

doing in Vònizòngo spread, and the subject of teaching the adult adherents to read, that they might be able to read the Bible for themselves, was brought before the church at the 'union meetings.' This stimulated our people again, and they worked eagerly until, first the epidemic, and then another conscription for the army, broke up nearly all the evening classes for a time; but the progress that was made in some congregations even during the very short time these classes were at work, was really astonishing.

When we settled at Fìhaònana in $187 \mathrm{I}$ there were probably not more than ${ }_{1} 5$, old and young together, in the whole district able to read, and we left over 3,000 ; so that if the only result of our work was that 3,000 had been taught to read the Word of God, and had been put in possession of it, our ten years in Madagascar were well spent. That was, however, but a very small portion of the work done in connexion with fifty village churches and schools with 2,60o children in them.

From 1874 to 1879 Madagascar was in a state of transition. A move had been made which necessitated progress on a more advanced scale, and in a more decided manner. One step had been taken out of heathen darkness and degradation into partial light. The people could not remain where they then were; they had either to go forward to higher and purer views of God's truth and duty, or sink back into a dead formality with only a name to live, or even into the darkness and degradation of their former conditions. There was great need as there still is, for the prayer, ' $O$ send out Thy light and Thy truth!'

I was often asked by friends at home to send them some interesting facts and cases. I sent many facts such as are contained in these pages. With regard to the 
'cases'-for, as I understood the request, it was cases of conversion that were meant-I am sorry to say that during our first term of service we were not cheered by seeing or knowing of very many. Yet, notwithstanding our inability to see all in the way of conversion that we longed for, we had a firm conviction that the Kingdom of God was making decided progress, even if it was only in the way of preparing the 'soil of the soul' for the 'seed of the Kingdom ' by educating and enlightening the minds of the people, especially of the young and rising generation, for the reception and understanding of God's truth.

Our good friends at home were very apt to forget the wise words of Dr. Livingstone already quoted, that most of the soil had to be prepared for the seed, and that-no matter how efficient the sower, or how good the seedthen it has to be sown, and, considering the paucity of the sowers, a great harvest could not be looked for: time also was needed for the growth of the seed. But there need be no fear for the harvest. It will come in due time. Still, as we all know, it is not always when the fresh green wood is crackling and roaring under the boiler, and volumes of black smoke are curling out of the chimney, that the greatest heat is being raised or the most steam generated. It is rather when the fire is at white heat, and all the black smoke and noisy gases are gone. It is not always when there is most excitement and noise, and numbers of cases being reported, that most real and lasting good is being done; but rather when the work is done in quiet. And, though a stage of excitement may precede, it is by no means necessary.

The rains which refresh the baked and thirsty earth in Madagascar and renew the face of nature generally descend amid the roar of thunder and the flash of lightning; but the latter do no good to the soil, or to the 


\section{Digging, Sowing, and Conquest}

growth of things: it is the rain which comes along with them, and especially the gentle rain that falls during the quiet of the night, that makes things grow.

Compared with such fields as New Guinea and the Congo, Madagascar has in some respects been the 'Paradise' of modern missions; but even in Madagascar large demands are made on the patience and perseverance and on the hopefulness of Christian missionaries; they cannot afford to grow weary and fearful, or faint-hearted as to results. They must be content to use the means and leave the results with God.

It is a great thing if they are allowed to dig out the foundations for the temple of the Lord, or even merely to prepare the soil for the seed, or sow the seed from which others shall reap. There is a danger of almost all missions of our day leaning a little too much on the past, and forgetting the many discouragements which preceded the missionary achievements which are now recorded on the pages of history. A wilderness had to be crossed before the promised land was reached. The Madagascar Mission might be, and perhaps is, in more danger of drawing on its past history than most missions, and might be excused a little if it did; but, if the spirit of its past history lives, it will continue to inspire fresh effort on the part of its missionaries of to-day, and on the part of those who have sent them there. With such a past as Madagascar presents there ought to be little danger of a 'rest and be thankful ' policy being followed. Conquest alone has made foreign missions what they are, and only conquest-i. e. conversions - can sustain them.

The Malagasy, even the Hovas, have been raised by the Gospel from the depths of depravity to live lives of purity and peace, and from darkness and superstition to the light of the knowledge of the glory of God made 


\section{The Dead Past}

visible in the face of Jesus Christ. They can hardly be called a demonstrative people in matters of affection or of religion, and yet, or perhaps because of that, their feelings with regard to both are often far deeper and stronger than many, who looking at them on the surface, would give them credit for. 


\section{CHAPTER XI}

\section{PROGRESS ALL ALONG THE LINE}

'The earth shall be full of the knowledge of the Lord, as the waters cover the sea.'-ISAIAH xi. 9.

THE schools occupied much of my time and attention. I was convinced that in no other way could I better serve the objects of the mission in Madagascar. The foundation for something higher than the three R's was laid. The minds of the children were stored with the knowledge of Him 'Whom to know is life eternal.' Some warm-hearted friends of missions seemed to suspect that we gave too much time and attention to our schools, and not enough to what they called ' the preaching of the Gospel.' They forgot that preaching is not the only means by which a knowledge of the Gospel may be imparted. Real 'evangelistic work' may be done to greater advantage in the village school than on the village green. The value which we assign to teaching is the result of experience. The means we had were not the best, but they were all that we had, and we made the best of them.

I did not like school work; I had had no special training for it. I preferred preaching and Bible-class work; but it was not a case of choice but of necessity. The schools had to be founded, worked, and kept at their best; they were the hope of the country and of 
Christianity in it. Of the adults, who had grown up in ignorance, superstition, and sin, I confess I had not all the hope I would have liked to have had of their becoming ' new creatures in Christ Jesus'; but of the children I had every hope. In them we had an approach to virgin soil on which to sow the 'good seed of the Kingdom.' As has been said, 'Men must be formed to the practice of the elementary virtues of Christianity before it is possible for them to recognize the beauty of holiness, and the nobleness and eternal obligation of righteousness.'

In point of returns for labour, we obtained the speediest and most satisfactory from the schools. At least onehalf of our congregations were heathen, or semi-heathen; and while we were glad to get them within sound of the Gospel, we knew that many of them attended church only from fear of the queen-a mistaken fear. The ' fear of God' had little to do with it. The sight that used to gladden my heart most, when I preached at my own station, was the 200 children sitting there in front of me. They answered the questions put to them with a fervour and eagerness which did one's heart good. They led the singing. Their voices made the church ring with the songs of salvation. They were the most attentive listeners to the sermon, and their eyes sparkled with an intelligence of which their poor parents knew nothing, and never would know: they were too old to learn, even if they wished to, which many of them did not. From the schools of the first missionaries came some of the foremost of the martyrs, and the best and most devoted pastors in the country. The truth learned by those men in the schools of former times sank into their hearts, and in due season brought forth fruit, before and conspicuously during the 'killing times.' Our 


\section{A Traitor checkmated}

schools were not merely secular institutions, they were essentially religious.

Our Quarterly Meeting became a source of strength to the churches. When the ritualists tried to gain a footing in the district, it was only the vigorous measures adopted by the Quarterly Meeting that saved one of the best of our churches from being ruined. The pastor who had invited them was an ignorant man, who had caused more trouble than all the other pastors of the district; but he was the petty chief of that village. $\mathrm{He}$ had been appointed to be the chief pastor of the church before we settled at Fihàonana. Being the chief of the village, many of the members were afraid to take action against him. They appealed to the Quarterly Meeting for help. The case was taken up very warmly ; Razàka and other two of the chief pastors were appointed to visit the church on the following Sabbath, suspend the pastor from office and membership, and appoint the second pastor in his place.

On the following Tuesday, when the would-be 'successors of the Apostles' arrived to do what the Apostle Paul carefully avoided, 'lest he should build upon another man's oundation,' they found that their quondam friend, who had promised to hand over the church and congregation to them, was no longer a member of that church, and therefore had no power to carry out his promise. Knowing the man as I did, and how such things were managed, I strongly suspect that he felt certain in his own mind, even if he had no positive promise, that his services would be handsomely recognized. Happily the whole affair was frustrated by the prompt action of the Quarterly Meeting.

Our girls' school at Fihàonana gave us no small trouble for a time; the parents kept taking away their 


\section{Progress all along the Line}

daughters of tender age to marry them, and prevent their attendance at school. Had this been done by heathen and semi-heathen parents only, we should not have been so surprised; but it was also done by parents of whom we expected better things, and I had to censure them severely for their conduct. My wife did her best for the schools, though she was hindered by scarcity of material for the sewing-classes, and the state of her own health. She was laid low several times with fever, and had to play the part of nurse to her household in their troubles. These seasons of sickness and anxiety, in addition to my daily burden of anxiety about all the churches, were often trying. Our people were kind at such seasons. They were grateful for all we had been able to do for them in their own seasons of trial. Indeed, the longer we were with them, the more we loved them, and, I believe, the more we were beloved by them.

About this time our good Christian queen set all the Mozambique slaves free. In her proclamation she said:- ' Now, the kingdom having been given by God to me, I declare that I will put a stop to these evils; for I am a sovereign tsy tia vèzovèzo (who dislikes disturbance, or quarrelsomeness). Therefore I decree, that I set free all Mozambiques in my kingdom to be ambàniàndro (subjects), whether those newly introduced or those who have been here for a long time.

'And if there are any who will not obey this edict, but still hold the Mozambiques as slaves, I shall count such as criminals, and the penalty of the laws shall be enforced upon them.

'And I also decree, that whoever has traded in Mozambiques can no longer make any legal claim in respect of such transactions. And if this decree of mine 


\section{A Marvellous Preservation}

is perverted by any one to deceive the wise or incite the simple, and so cause disturbance in my kingdom, then, whoever he may be, I will hold him guilty, and condemn him to death; for I am a sovereign that will not deceive.'

We all had a most merciful and marvellous preservation on the evening of Sabbath, December 2, when our house was struck by lightning, during the most terrific thunderstorm that had been known or heard of by the oldest inhabitant. It had been intensely hot and oppressive during the previous fortnight, but especially so that Sabbath. It seemed that such heat must soon lead to something. Towards sunset the clouds gathered, the sky grew dark-sure signs of the approaching storm. As we sat at tea, I heard the first mutterings of the thunder in the north-west and remarked: 'There's relief coming at last.' After dark, as the storm drew nearer, the roll of the thunder became louder, and the flashing of the lightning more awful. As the hours of the evening passed, the storm seemed to be gathering strength for a final outburst. We heard the roaring of the wind increase, until it had the force of a tornado. The rain fell in torrents, and vivid and yet more vivid flashes of lightning were followed by louder and louder rolls of thunder. It led one to think of Him Who is 'a hiding-place from the wind, and a covert from the tempest.'

At a quarter past nine a blinding sheet of lambent flame enveloped the house. For an instant the whole yard seemed to be flooded with living fire. This was followed by a terrific explosion in one of the lower rooms. There was a lightning-conductor twelve feet high on the centre of the roof; but the lightning, as was afterwards discovered, in striking the rod had 
melted the silver from it, and glancing from the rod to the gable, had gone down the chimney of the lower room, where it exploded. The ceiling at the south-west corner was torn down, the floor of the bedroom above, right under the baby's cot-from which she had just been lifted-was blown up. The current then went up the wall of the room to a copper bell-wire. It ran along this wire, along two sides of the roof of the room, the roof of the lobby, two sides of the roof of the children's bedroom, and then down the wire in the corner of the room, broke the bell, ploughed its way down the wall over the inner door of the kitchen, which it smashed, through the doorway and the kitchen, escaping finally by the outer door, after knocking the cook down on its way, and burning him severely!

My wife, baby, and nurse were in the bedroom, and their escape from death was marvellous. The baby had wakened a few minutes before the explosion, screaming so piercingly that my wife-who had gone to bed-had to rise, lift it from its cot, and try to quieten it. She rang for the nurse to prepare its food. She took a step forward, to take the milk from the girl, and to that step, humanly speaking, she owed her own life and that of the child; for just at that instant the house was struck, the explosion took place, and the spot from which she had just stepped was blown up, the flooring being thrown over her head, a piece of one of the boards falling on the head of the nurse and cutting it open!

Sitting in the room adjoining, I knew the house had been struck, but thought the noise of the explosion was caused by the falling of one of the gables. A deathlike silence followed, and then the screams of my wife betokened her fright, and her agony of fear for the other children. We found them, however, to our un- 
speakable relief, all safe, and sleeping so soundly that not even the terrific explosion had wakened them. And although the electric current had gone down the copper wire in the corner of their bedroom, within a few inches of our eldest daughter's head, not a hair of her head had been harmed.

We had a very interesting case, which I shall relate, as showing how the truth was working its way into the hearts of some of our young people. It was that of a young and very poor petty chief. Although a chief, he had not felt that he was degrading himselfas many would have done-by working for me in various ways. At first he learned to make bricks, then he carried wood while the manse was building. I had noticed that he was among the most diligent of all who worked for me. After the building was finished, he was asked to come to school, and, although much older than the majority there, such was the progress made, that he was several times sent out as a teacher. I had often observed him in church paying marked attention to the preaching, and I hoped the truth was finding its way to his heart. He called one day to ask for a copy of the Catechumen's Catechism, and to tell me that he wished to become a candidate for baptism and church membership. I examined him on three occasions, had several most interesting conversations with him and had every reason to be satisfied, and recommended him for church fellowship.

A few weeks after he called again, and said that since he had joined the church, he had been very much exercised in mind as to what he ought to do to advance its interests. He desired work to be assigned him. He also wished to attend my classes, and to go out as a local preacher on the Sabbath. He became a most 
regular attendant and went out almost every Sabbath preaching. I afterwards gave him some months of private instruction, and sent him up to the Institution at the capital. After four years' training he returned to Vònizòngo, took up the work of an evangelist, and has done splendid work for twenty years.

From the returns for the year ending $\mathrm{I} 878 \mathrm{I}$ find that $£ 89$ i is. $9 d$. was raised in the district for church purposes, and $£_{4} \mathrm{I} 18 \mathrm{~s} .2 \mathrm{~d}$. for the salaries of teachers; in all, $£$ I 3 I $9 s$. I I $d$., equivalent to $£_{57} 9 s .7 d$. The contributions of the entire district for 1868 had only reached the very modest sum of $£ 28 s .6 d$. When we settled at Fihàonana in $187 \mathrm{I}$, Razàka handed $£ \mathrm{I}$ ros. o $d$. to me to keep for the church, that being the sum in hand from the church-door collections, less expenses, for the previous nine years! During our nine years at Fìhàonana, our small station church of some ninety members, a third of whom were slaves, raised upwards of $£_{1} 5^{\circ}$, while $£ 700$ was raised by the other small churches of the district, equivalent to the people to $£_{75}$ and $£_{3,5}$ oo respectively of our money ${ }^{1}$.

The work kept steadily advancing, year after year, and our people made quiet but distinct progress in Christian knowledge and in Christian character. The darkness of their former state gave way before the light of the Grospel, and our hearts were gladdened by seeing results from our former labours. For a time our work suffered interruption from a severe epidemic of malarial fever in the central provinces, which resulted in a large death-rate. We ourselves also suffered severely. In consequence of this epidemic, my medical work was greatly increased,

1 'The Malagasy love to give, especially for the Kingdom of God; and this happy disposition, created by our English (British) predecessors, is being carefully maintained!'-M. Bianquis, 1903 . 


\section{The Deadly Fever}

but my ordinary labours among the churches, schools, and Bible-classes were much interfered with, and almost all teaching was suspended for a time.

For about four months every year-from February to June, known as the fever season-malarial fever, diarrhoea, and dysentery were prevalent in Vònizòngo. This being a great rice district, the harvest season and just after it, April and May, were generally the worst for fever, \&c.; but the year 1878 was exceptionally severe. Strange to say, however, those portions of the district which formerly had suffered most from this scourge had only a slight visitation, while those which had been comparatively safe hitherto suffered most on this occasion. In our neighbourhood the attack was severe. All over the central provinces about forty per cent. of those who were seized died. About two hundred fatal cases occurred in connexion with our station.

It must be borne in mind, however, that the majority of those who were attacked received no proper medical treatment. Of those who could and would receive medicine, the great majority recovered; in fact, very few cases proved fatal. In the more distant and less enlightened villages hardly a person could be found ready to give up the native nostrums and risk trying proper remedies, hence the excessive mortality. Simple medicines and proper nursing were almost all that were needed; but hundreds of poor ignorant people would not take proper medicines, even when offered to them for nothing.

There was a range of hills, about two miles to the west of our house, on the opposite side of an extensive rice valley. The people in the villages along the foot of that range suffered severely during the epidemic. Razàka and some of the deacons went to visit them when the 
epidemic was at its worst. They found the poor creatures in a miserable condition, five, six, and even eight lying in a single hut, prostrated with fever, and in several cases with the corpses of children which no one had been able to bury. And yet hardly one in ten could be persuaded at first to give up the native nostrums, and accept the medicines we had sent them. In some cases they even denied they were ill, lest my messengers should give them quinine, while some were so ill that they could hardly articulate.

I asked Razàka the reason of such repugnance to the proper remedies, and he replied: 'Simply ignorance, foolishness, and superstition.' While some few refused the quinine as being too bitter, and others because they were afraid it might bewitch them, the majority declined to take it because it was too powerful! They said they knew very well that the white man's medicine would cure them, for it was powerful; but it would not only cure them, it would also quite destroy all the virtue of their own medicine. If once they took white man's medicine, nothing except white man's medicine would ever cure them again. They had a white man and medicine now, they said, but as they did not know how long they might have either, they preferred keeping to their own $o d y$, on which they could fall back in their time of need. They did not seemingly take death into account.

As we could not stand aside while these ignorant creatures committed suicide, and practically murdered their children in their folly, bottles of quinine mixture were prepared, and Razàka and the deacons were sent to the villagers and were told: 'If they won't take the medicine willingly, pour it down their throats.' They did so, with the result that the poor creatures were 
cured, and fell fairly in love with the odi-tàzo (charm for the fever). They would not take it even for nothing that year; but, the following year, bought $£$ I I worth of quinine during the four months of the fever season!

The Malagasy regarded all disease as the result of witchcraft, and so all medicine was fànafódy, that which takes off or removes the $\dot{o} d y$ (witch charm). Our medicine was therefore regarded as the most powerful $o d y$, which not only cured the patient, but also conquered and destroyed the virtue of all other and weaker $\dot{\partial} d y$. This reluctance is still met with in the darker parts of the island. The people came to call quinine od $i$-tàzo, the charm for the fever; a wash for the eyes, odi-màso, a charm for the eyes; and a cough mixture, odi-kohaka, a charm for the cough.

During the time that the epidemic was at its worst, I 2 ounces of quinine were disposed of in six months, and we lost only one patient by death in our village. Thus a victory was gained for our medicines and mode of treatment of the sick, while a heavy blow was dealt at the native nostrums and absurd methods of treatment.

Many of these poor sufferers were in a state of delirium. This the Malagasy know as miàrahàba ny $a k o$ ho, i.e. saluting the fowls. The Malagasy are very polite. If they meet a superior, or if he enters their hut, he is saluted with: Tsàra và tompokò è? i. e. 'Is it well with you, my lord?' While lying ill with fever, the fowls would find their way into their huts, and hearing the pattering of their feet on the mats, the sick would imagine, in their delirium, that these fowls were their superiors come to visit them, and would salute in the usual way: 'Is it well with you, my lord?' Hence 
one in bad fever delirium was said to be saluting the fowls.

The state of emaciation in which some were brought to us was terrible. Their faces wore a hue between green and grey; the white of the eyes was a greenish yellow, and imparted a hideous aspect to them. The spleen was generally very much enlarged. They were brought in all states and conditions, and sorely taxed my limited medical knowledge, as they taxed my sympathies. Poor miserable slaves-more like skeletons encased in leather than human beings-came begging for quinine. They had no money to buy it, nor would their masters give them any; but I could not refuse them medicine.

My wife and I both suffered severely from the fever, which left us very limp and shattered in health; but we felt thankful that our children escaped as they did. As soon as we were able to travel, we went to the hills for a month, which braced us up again.

During my absence the ritualists made another attempt to get a footing in the district; but they failed. By throwing the burden of keeping the teachers they wished to send out of the district upon the natives themselves, I so put them on their mettle that they were more anxious than even $I$ was to keep them at a distance.

After the epidemic of fever, we had a slight visitation of small-pox. Of course the majority of the people were very foolish over vaccination. Great numbers of them would neither be vaccinated, nor allow their children to be so. Still, we did manage to vaccinate a fair number of children, and more adults than at any former time. Only a few could be persuaded to bring back their children, that others might be vaccinated from 
them, or the lymph be taken off. I taught a few of the more intelligent pastors, local preachers, and teachers how to vaccinate and supplied them with lymph, and so we had most of the people in our own immediate neighbourhood vaccinated one way or another. I was very anxious to get that done, as four of our own children had not been vaccinated, and I had no lymph with which to do them until I obtained some from England. Yet though we had vaccinated all in the villages near us, it was not such a protection as it ought to have been, as the garments of those who died of small-pox were in many cases sold in the public market!

The natives had rather a rough and ready way of vaccinating. They made three small cuts on the left arm with a piece of glass-generally a piece of a broken bottle-put in the lymph, closed the cuts, and then put on a small plaster of boiled rice to keep the edges together. Some of my cases did not ' take,' but I think all theirs did.

Our fine new school-house was finished and opened at the end of the year. We had most successful opening services, at which the queen's representative was present. $\mathrm{He}$ also handed the prizes to the 336 who had distinguished themselves in the examinations.

The congregations all over the district continued to keep up well; most of the churches were well filled at the Sabbath services. The attendance at these services was not in every case due to fervent piety or the desire for instruction. Many only desired to stand well with the local chiefs and the authorities. Still, whatever their motives may have been, it was well that they were there; for while they were in church they were at least out of the way of much temptation to evil, and they 
heard the Word of God, which was blessed to many who were led to see themselves as sinners, and to seek Him Who came to seek and to save the lost.

The congregations made most marked progress during that year in the grace of generosity to the cause of God, and for the support of the school teachers. The previous year, the twelve small churches under the charge of the trained evangelist had raised their share of his salary for the year- $£_{4} \mathrm{I} 6 \mathrm{~s}$. - in advance, the first time that such a thing had been done; but during that year the unprecedented sum of $£_{3} \mathrm{O}$, equal to them to $£_{15} \mathrm{O}$, was raised in the district a rohole year in advance, to pay the people's share of the salaries of six trained teachers settled among them, and four evangelists about to be settled. Such a thing had never been done before in the history of the island. We felt very pleased and thankful for what we had been able to teach the people to do ; the more so, as we had the satisfaction of knowing that we were not only the first, but up till then, at least, the only missionaries in the island who had been able to persuade the Malagasy to raise such a very large sum a whole year in advance in order to pay their share of the salaries of their teachers and evangelists.

Now and then in some quarters there were signs below the surface of remnants of heathenism and semiheathenism. We had some displays of this nature during the epidemic, when many were panic-stricken. We had one sad sample during that year of the heathenism still remaining brought to light by the death of the young wife of one of our trained teachers. Her parents, although they attended the village church occasionally, were evidently heathens at heart. Her father was a retired Hova governor, reputed to be rich. He made a great funeral feast, for which a number of oxen, sheep, 
and pigs were killed. The corpse of his daughter was rolled in thirty-four silk làmbas (plaids), while all the best and most expensive dresses and ornaments, \&c., belonging to herself and her mother, were placed in the family tomb along with the corpse. Money to the amount of $£ 24 s$., equivalent to $£ \mathrm{I}$, was put into her grave-clothes for expenses in the other world, while $£_{3}$, equivalent to $£_{1} 5$, was paid to the so-called musicians who made day and night hideous by their discordant noises from the time of her death to that of her burial, to keep the bad spirits at a distance, and little wonder if they did! In all, $£_{3} 2 s .9 d$., equivalent to $£_{4} \mathrm{I} 5 \mathrm{I} 3 s .9 d$., was worse than wasted over the funeral of that poor girl by her heathen parents.

In my long journeys in Madagascar, I always suffered from the heat-a sort of mild form of something of the nature of heat-apoplexy I should suppose-and hence in our journeys from our station to the capital or back, we always started very early in the morning, generally at four, often at two o'clock, so as to get to the journey's end before the hottest and most exhausting part of the day-about three in the afternoon. Though generally suffering from headache by the time I got in, a night's rest as a rule set me right again.

Twice had that long weary journey home from the capital to be undertaken by moonlight. I got a lady's palanquin-a long oblong box made of strips of sheepskin fastened to two long poles-and lay down in it with a rug over me to protect me from the dews of the night, covered my face with my helmet, and tried to sleep, but not with much success.

I arrived at home suffering from very severe headache, which lasted for the following four days. A night's rest was enough to free me from headache from exposure 


\section{Progress all along the Line}

to sunlight, but it took four days to do so from that of exposure to moonlight. I could not understand this at first, nor till the text came into my mind: 'The sun shall not smite thee by day, nor the moon by night.' The moon smites, in some senses, more severely than the sun, and the effects remain longer. Of course if the effects of the rays of the sun reach the point of sunstroke, the result is far worse than anything the moon can do. 


\section{CHAPTER XII}

\section{GATHERING CLOUDS}

The earth shall be filled with the knowledge of the glory of the

Lord, as the waters cover the sea.'-HABAKKUK ii. I4.

AN embassy was sent by the British government to Madagascar in the summer of 1880 . The late Admiral Gore-Jones and his staff went up to the capital and spent some time there in interviewing the queen and prime minister and in interchanging courtesies. Ostensibly his mission was to remonstrate about the slave trade on the west coast, to offer assistance in putting it down, even to the carrying of Hova troops to be placed at stations along the coast. Some suspected at the time that that was but a blind, and that the admiral had a secret mission; and it has been asserted by those who profess to know that he was sent out to feel the pulse of the Madagascar government, and find out not merely whether any wish for a British protectorate existed, but to definitely offer one if there were any likelihood of its being accepted.

There can be little doubt now that the interpreter was even then a traitor in the pay of the enemy, and he interpreted nothing of importance communicated to the prime minister. The Jesuits boasted after the war that they won Madagascar for France, and, however 
foolish in their own interests with the people such a statement made publicly may be, it was generally believed that for once they had told the truth. They had had a grant of $15,000 \mathrm{f}$. a year for many years (previously, I believe, it was very much larger), which was greatly increased after the war, and they earned their wages by their political intriguing.

An agent and protégé of theirs had long been at work in the palace. He received a handsome salary which he also had infamously earned; for he succeeded in seducing some of the chief officials from their allegiance, forming a party in the very cabinet itself, by whom the country was sold, and the people who trusted them basely betrayed. Hence the poor show the Malagasy made in fighting for their fatherland, until they found that they had been betrayed, and then they rose in rebellion against the French rule when it was too late. Madagascar and its people were betrayed, sold, bought, and paid for, and then the chief intriguer, who was also one of the arch-traitors, when he had done his infamous work was flung aside, while it is said that the other arch-traitor and some of his confederates had to pay large sums for their worthless lives.

We returned to Madagascar in 1882 , but not to our old station, which had been filled up. There was, however, need for some one to take charge of the city church of Ambàtonakànga and the large country district during the furlough of its missionary, and after the way that we had both suffered from fever in Vònizòngo the Directors thought that it would be wiser for us to be in the capital for the first two years to become reacclimatized. The missionary did not return after his furlough, and we were accordingly appointed to take permanent charge 


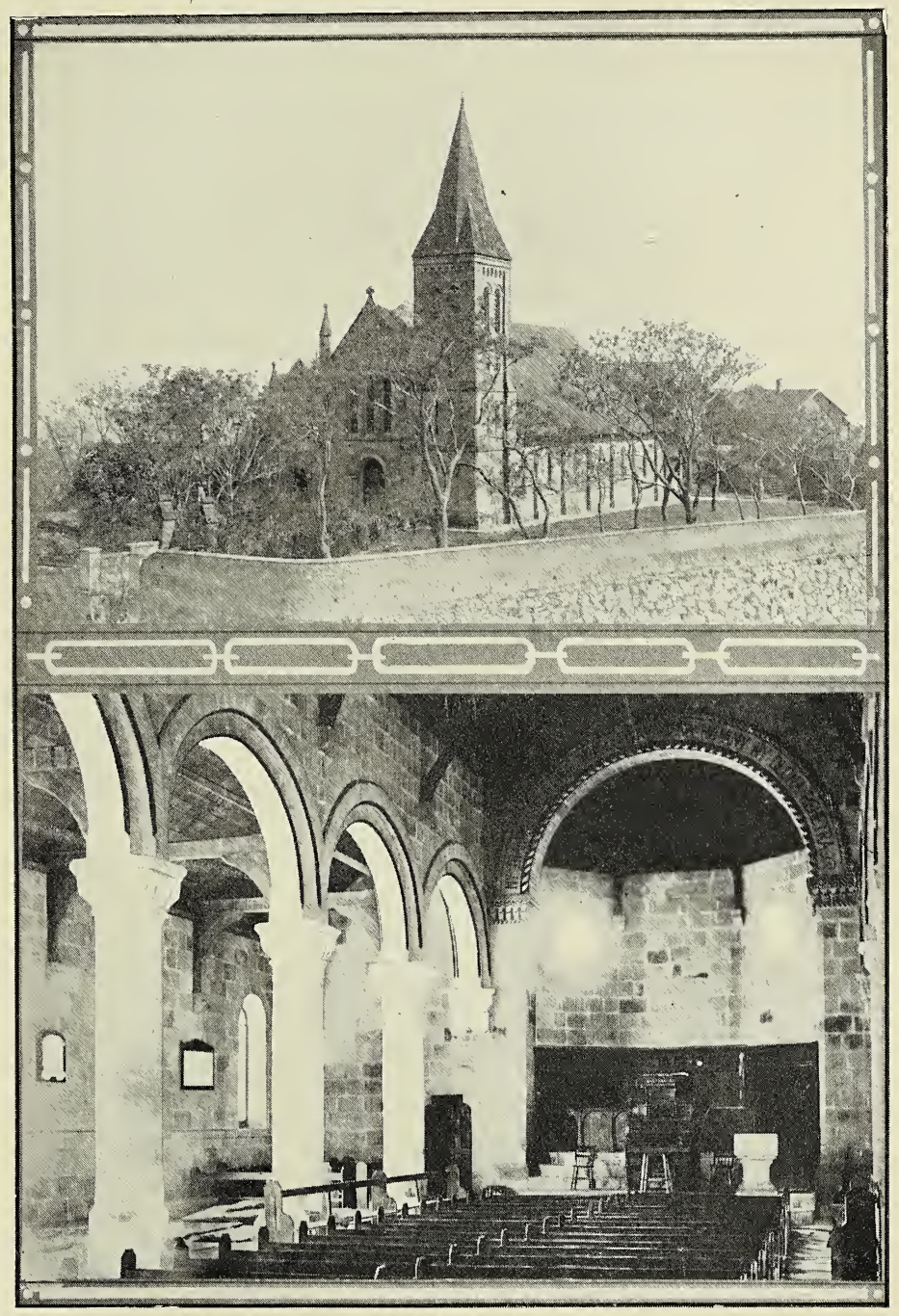

MEMORIAL CHURCH, AMBATONAKANGA.

INTERIOR OF THE CHURCH. 

of the city church and country district of A-kànga ${ }^{1}$, and remained in charge of it for twenty years.

The interest created in our work, deepened by the many services I had conducted and by my pamphlet, took a very practical form ; for the ladies of the Presbyterian and Congregational churches in Aberdeen sent us four boxes of remnants, patches, sewing-material, and some good cast-off clothing, all of which were of the greatest service to us; for by means of these my wife, assisted by six Malagasy sewing-mistresses, held, for six years, sewing-classes in connexion with the city Congregational school and the village schools for some 700 girls. By that means an immense service was done to the girls in the village schools, such as we could never have done for them had it not been for the efforts of these good and warm-hearted friends. Even such a good work had some drawbacks, however; for as it could not always be carried on some felt aggrieved, and when my wife and daughter came out in 1894 , as that work could not be taken up to the same extent, many thought that they were being defrauded of their rights.

It was by no wish of our own that we went to the capital; for we had never taken to it, or to the spirit that then reigned in it and its churches, and we wanted to return to our old station, where we had spent so many useful years. We afterwards found, however, that God had work for us to do at A-kànga and in the district, although certainly not all of it work which we would have taken up by choice, and that the Directors had been wisely guided in placing us there. We found the work at the capital somewhat different from Vònizòngo, and the state of affairs at A-kànga very different from that of our old station. Some of the mischief at

1 Shortened form of Ambàtonakànga. 
A-kànga we found to be the outcome of causes over most of which my predecessor had had little or no control, as they had been at work years before he went there:

The church at A-kànga had been formed by a nucleus of good people, some of whom had suffered for their faith during the 'killing times,' and the late Rev. William Ellis was the first to take charge of it. A number of officers, judges, and palace officials afterwards joined it, few of whom were ever any help or credit to it. When the palace church was formed many of them left and joined it. By the time of our settlement most of those who first formed the church had passed away, and, although there was still a nucleus of good people, they were greatly in the minority, while they occupied a lower social position than the majority of the so-called members and adherents. Most of these were very haughty, conceited, and self-righteous, and as destitute of real religion as the stone pillars of the church wherein they worshipped.

The senior pastor was in keeping with this part of his flock; he was the judge already mentioned who stole the ox which our people at Fìnàonana had provided for the queen's messengers and the others who came to the opening services of the church. He had entered into the joint pastorate in the time of Mr. Ellis, whose successor had skilfully shelved him; but he had joined it again during the time of my immediate predecessor. There was much therefore that was most unsatisfactory in the mother-church and the country district when we took charge in 1882 . Mr. Ellis, like other good men, often made the mistake of taking the Malagasy for their own profession, and at their own valuation, with the result that he was imposed upon and deceived, 


\section{A Spoilt Church}

and by none more than by the relations or professed relations of the martyrs, towards whom his heart was very warm. It is better to be sometimes cheated than never to trust, but if a man trusts every one he will be certain to trust mere pretenders and in the end be deceived as Mr. Ellis was.

Appointed locum tenens to the A-kànga church, I entered like a stepfather into a spoiled and badly brought-up family. While merely locum tenens I could do but little to improve the state of affairs, although we were able to do something.

The state in which we found the A-kànga motherchurch arose perhaps somewhat from the fact that there had been for some time a great deal of friction between my predecessor and it, from a cause as creditable to him as it was disgraceful to the church. One morning on his way from his house to the city he came upon a poor slave woman in chains, sitting crying by the roadside (a most unusual sight-I never saw such a one), and as the chains had broken the skin of her neck and ankles they were bleeding, and she was besmeared with blood. He was so touched and exasperated by the sight that he returned home, and at once wrote to the queen telling her of what he had seen. Her Majesty sent and had the woman brought into her presence, and she was so touched, shocked, and angered by the sight of the poor creature, besmeared with her own blood, that she ordered the chains to be taken off at once and put upon her owner!

A most drastic proclamation was drawn up there and then on the subject of the treatment of slaves, and even printed at the government press; but what its tenor was we never knew, as it was suppressed; for after the queen had cooled down the prime minister and cabinet 
represented to her that to put the woman's master in chains, and to issue the proclamation, would cause a revolution, and might cost her not only her crown but her life, and theirs also, as the people were not ripe for such drastic measures. On their knees they pleaded with her to revoke the proclamation, which she wisely did.

There was great excitement over the affair, during which my predecessor found out that the heartless owner of the slave was a member of the A-kànga church. $\mathrm{He}$ at once brought the matter before a church meeting, representing that a man who would treat any human being, especially a woman, in that manner was unfit to be a member of the church. To his astonishment and disgust the meeting sided with the slave owner almost to a man (as of course all the other slave owners had made a point of being present), and from that time my unfortunate predecessor was opposed and thwarted by the semi-heathen portion on almost every possible occasion.

The missionary then volunteered to take a journey along the east and north-east coast, on behalf of the native missionary association of the 'Union,' to visit their stations and five evangelists. This journey, I believe, ultimately cost him his life; for he returned from it so filled with malarial poison that he was very ill for months-in fact, his life hung on a thread for weeksand, although he recovered then, he was never again the same man, and he died some six years afterwards. His authority having been weakened by the opposition of the slave owners and other worthless members of the church, his long absence owing to his journey and subsequent illness, during which the church had been left very much to itself (which no church could then be without 


\section{Sunday-School Work}

getting into an unsatisfactory state), were both causes of the condition in which we found it. It did not reach a satisfactory state until the old church was broken up and a new one formed.

Once, while on a visit to the capital from Vònizòngo, I had expressed my astonishment that there were no Congregational Sabbath schools. I was at once told that such an idea showed plainly that I was a country brother; for if I knew anything about work in the capital, I should know that Sunday schools could not be held there. I did not accept that statement as correct. A general Sabbath school for the children of the capital had been opened in the. Friends' high schoolhouse about $\mathrm{r} 877$, but what was one in a city of 80,000 inhabitants?

We had reached Antanànarìvo on our return from our first furlough in August, 1882, and on the first Sabbath of October I appealed to the church to help me to begin and carry on a Congregational Sabbath school, and asked for volunteer teachers from among the young men and women. Thirty-six volunteered, some from very mixed motives and mistaken ideas. For a year afterwards some of them asked me when I intended paying them for their teaching. I replied that I would pay them as soon as ever they were out of debt to the Almighty for food and raiment, health, strength, Gospel privileges, redemption, and freedom to worship Him. I heard no more about remuneration for Sabbath-school teaching.

We gathered a Sabbath school of two hundred which, although the numbers were allowed to fall while we were away on our second furlough in $1890-2$, has kept up well ever since, and done much good work. The old deacons, however, regarded it as a new-fangled idea of mine and 


\section{Gathering Clouds}

of the young folks, and would have nothing to do with it. They told me that my predecessors had had no such notions, and asked why I could not be content to follow in their footsteps. I pointed out that the time might not have been ripe for Sabbath schools in their days, and asked them what they would think of a mother who threw her children into the street instead of nursing them. But it was of no use; they were so firmly opposed to the introduction of Sabbath schools that they would hear nothing in their favour.

A few weeks after we had begun one of the brethren, passing home from church one Sabbath, saw our churchdoor open (after canonical hours), and came in to see the cause. He found the Sabbath school at work, and asked what was the meaning of the gathering of children. When I told him he seemed a good deal astonished, and what he saw and heard led him to bring the subject of a Congregational Sabbath school before his motherchurch, the result being that they too set one going. The superintendent of the London Missionary Society press, who had charge of an important suburban church, hearing of our venture at A-kànga, began a Sabbath school next, and so one city church after another followed our leading-although some were two years before they did so- until all had Congregational Sabbath schools. The movement spread into the country districts, and for many years now all the most important districts have had Sabbath schools connected with their village churches. Many of them are very weak, some of them not much more than names; but still the movement has received a good start, is recognized as the right thing for every church to have, and as a most decided improvement on the past.

While on furlough I first met with an agent, and 



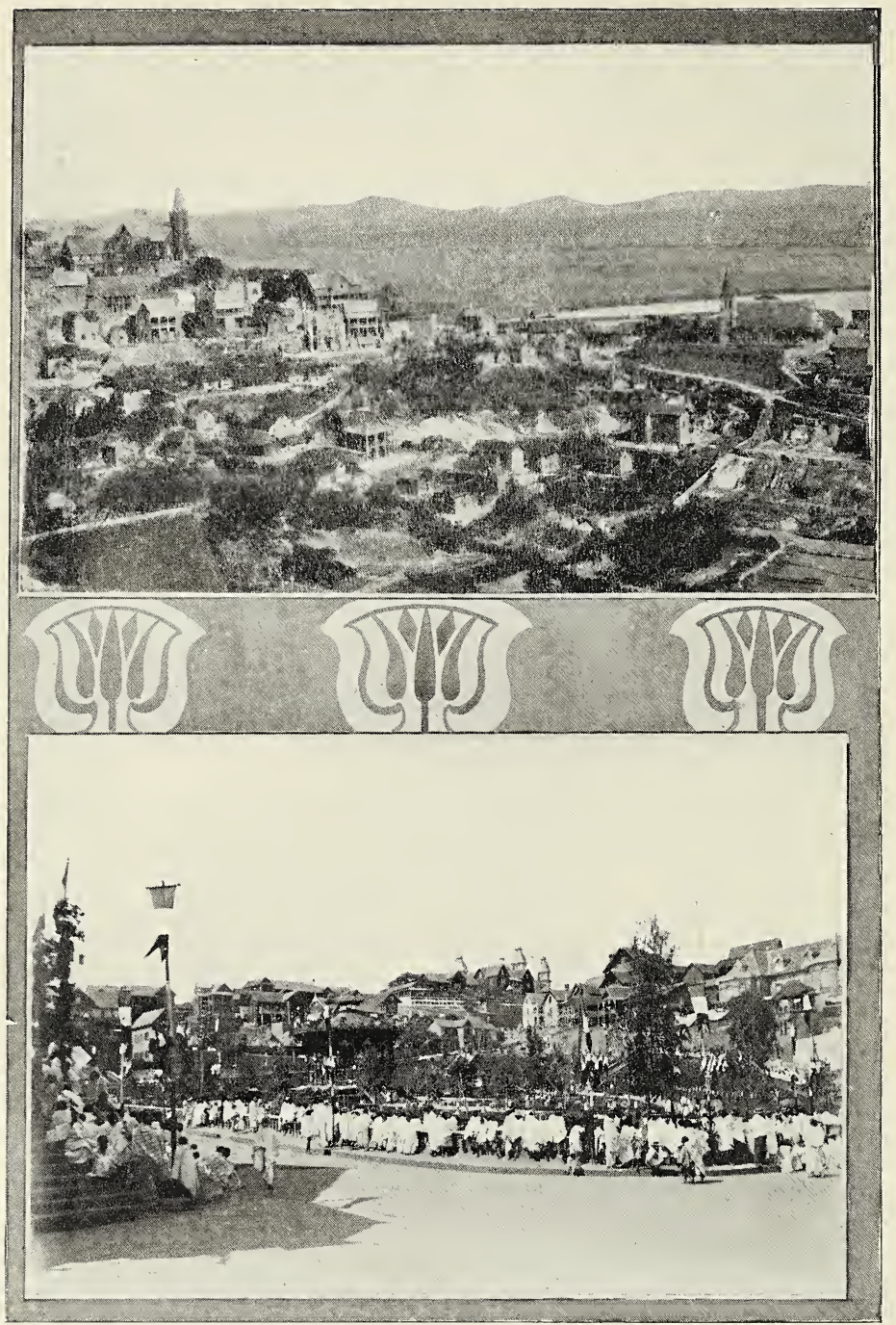

AMBATONAKANGA FROM FARAVOHITRA.

ANTANANARIVO ON A FÊTE DAY. 


\section{Working by Wile}

then with the secretary of the Children's Scripture Union, and undertook to begin a branch in Madagascar, and for many years we have had there 12,000 members.

I found the village schools in a poor condition; for my predecessor had had very little private help for them, almost nothing except the grants made by the Imèrina district committee for elementary education, and so had to be content with a very inferior class of teachers, as the parents could not be persuaded to pay for properly trained teachers. After the first examination of the village schools when we took over the district, the returns were so poor that I determined to make an effort to get the parents to give more in order to secure trained teachers. I knew I would have to catch them by guile, and be able to show them in a striking and impressive way how they were defrauding their children, in not doing their duty by providing properly trained teachers for them.

With this end in view I gathered seventeen village schools at one centre in the largest church in the district to give out the prizes. On the prize-giving day I took three porters with six baskets of books of various kinds with me for prizes, about the quantity I would have required for the same number of schools in Vònizòngo. The church, although an immense place, was crowded in every corner with scholars, parents, teachers, pastors, and deacons, while dozens, not to say hundreds, were at the doors and windows. When I had distributed the prizes to all who had earned them, I found, as I expected I should, that I had only disposed of the contents of two baskets, leaving four untouched.

I called the attention of the parents and all present to 
this, and told them that, considering the number of scholars present, if even two-thirds of them had earned prizes, as they ought to have done, and would have done in Vònizòngo, all the six baskets would have been empty. I said nothing gave me greater pleasure than to gladden the hearts of the scholars by giving them the prizes they had earned, and that I would have been delighted to have given the contents of all the six baskets to their children; but, as they had seen for themselves, they had not earned them, and therefore had not received them. 'But why is this the case?' I asked. 'Because the children were stupid or had no ability or keenness? By no means,' I said; 'but simply because their heartless parents would not pay for proper teachers for them, and so the poor children will have to go home from the prize-giving weeping instead of rejoicing carrying their prizes with them. Look,' I said, 'at your children; where would you find brighter-eyed, cleverer children? If they had only had proper teachers they would all have gained prizes.'

The parents went home, followed, as I expected, by their weeping children. They immediately discharged the cheap incapable teachers, applied to me for trained ones, and for the following eighteen years I had no trouble in raising the people's share of the salaries of the trained teachers. The superiority of the schools of the A-kànga district was noted by both deputations of the Paris Missionary Society. They remarked in particular the ability shown by the children in Bible knowledge. This was due to the number of trained teachers we had. The late Professor Kruger, after being present at one of the poorest examinations in Scripture they ever passed (as the schools had been closed for three months that year on account of the war), said that he could not get 
a Protestant school in all France which could approach them in Bible knowledge.

We had many visits from our old friends from Vònizòngo, who were looking forward to, and fondly anticipating the time of our return at the end of the two years, when we all expected my predecessor in the capital back from furlough. One after another came to see me, and to tell me of the good they had received from my ministrations during our nine years among them, and of the new life and hopes to which they had been lifted by religion. If they had only come and told us a little, before we left on furlough, how much they would have cheered us, and how much it would have done for us! Still we were glad to hear what they had to tell us even then. It proved that we had not been labouring in vain.

What, however, has been said of the influence of teachers and preachers at home may be affirmed with much greater force of workers in the foreign mission fields, that they 'are of all influences the most intangible: their thoughts enter the intellectual life of men-such as it is-and shape it, and the moral and religious life of men and fertilize them, but it is as the rain fertilizes the soil, itself disappearing in the process, leaving those benefited often utterly unconscious of the blessings they received.'

After a time I was able to get village school-boardssuch as we had in Vònizòngo-established in the A-kànga district, and on the whole they did very good service up to the time of the French invasion in 1895 .

The Malagasy government sent an embassy to France in 1882 , to see if the difficulties between the two governments could not be amicably arranged. The 
embassy afterwards visited England and America, but without being able to attain their end. In $188_{3}$, because the Malagasy government would not yield to certain demands made by the French, war broke out. Without any warning the ports on the north-west coast were bombarded, and the town of Mojangà was occupied. Soon after Tàmatàve, the port of Madagascar on the north-east coast, was taken, or rather was abandoned by the Hovas, and thereafter occupied by the French. A fortified camp at Fàrafàtana, a few miles to the west of Tàmatàve, was formed by the Hova troops, and although Tàmatàve was held by the French for nearly three years - mainly by means of their warships-and the camp at Fàrafàtana was within reach of their guns, and was constantly shelled by them, and several attempts were made to carry it, yet the Hovas held it to the end of the war. This was almost entirely through the ability, energy, and determination of the late Governor of Tàmatàve, who was shot for his pains in 1896 .

When the French sent up their ultimatum to the Malagasy government all French subjects, of course, received notice that they must leave the island. The Jesuits, Sisters, and French and French-Creole traders had a fortnight given them in which to prepare to leave for the coast. The British subjects in Antanànarivo formed themselves into a committee of public safety; not that we were in any real danger, but rather that we might act in unison. The prime minister sent for us, and advised us not to go far into the country, as the people were very much exasperated by the action of the French, and the vast majority of those in the country districts were ignorant of the distinctions between French and British. We were all white men to them: mistakes might be made. As a matter of fact some 


\section{A Sensational Display}

were made, and others only just prevented. Some members of the Society for the Propagation of the Gospel Mission were mistaken for Jesuits, and were consequently hustled about before the mob could be made to understand that they were British and not French priests.

On the day on which the Jesuits and Sisters had to leave the capital they started to walk to Tàmatàve, carrying their things in small bundles; but since to attempt to walk would have been perfectly suicidal, we doubted if they ever meant to do it; we fancied it was only a sensational display on their part. We were holding a meeting of the committee of public safety when the news was brought to us that they were starting, and we immediately sent our officials to see them, and discover if they had the means to pay for porters or if it was that they could not hire them. If they had the means, but could not get the men, our officials were commissioned to procure them, and if they had not the means, and could not hope to have, when they reached the coast, they were to find porters for them, and we would be responsible for their wages, as we could not allow European ladies to virtually commit suicide by walking to the coast, simply because they had not money to pay for palanquinbearers.

When our representatives reached them they found that the queen and prime minister had heard how they intended to go, and had sent them palanquins and bearers from the palace, together with a captain and ${ }_{5}{ }^{\circ}$ soldiers, who were instructed to protect them, and obtain suitable food and shelter for them on their journey. They would all have received short shrift at the hands of some of the old heathen Hova officers if 
they could have had their will. The old heathen party were vexed at the kindness of the queen and prime minister towards the French subjects, especially towards the Jesuits. If they had had their way, as happily they had not, there would have been no exodus of French subjects.

Knowing what we do now, from the public boast of the Jesuits themselves, that 'they gained Madagascar for France, and for this ought to have a free hand'; remembering also that these officers were heathens at heart, and that they had only too good reasons for suspecting the Jesuits of playing false, it is not to be wondered at if they wished to follow the old heathen method of dealing with such deceivers; but the queen and the prime minister were wisely advised to act as they did. The policy which the heathen officers wished to follow would have belied the Christian profession of the queen and government, and played into the hands of their enemies, who wished to provoke them to acts which would prove them the barbarians they maintained they were. As the lives of Europeans were respected and their treatment was in every way worthy of a civilized and Christian government the conduct of the Malagasy officials contrasted favourably with that of their antagonists. The French government of that day may have been very much deceived-indeed I am sure they were, and had their hand forced-in many ways; but some thought they were not over anxious to know the truth. The Jesuits and Sisters were ultimately sent to the nearest French colony, Réunion, in a man-of-war, and had to remain there to the end of the war.

To add to the embarrassment of the situation the queen, Rànavàlona II, the first Christian Queen of 
Madagascar, after an illness of some months' duration, died on the morning of Friday, July I3, I883. This event, so shortly after the commencement of the war, seemed as if it might prove another blow to the progress of Christianity; but it did not. We had heard that Her Majesty was ill, but were startled that Friday forenoon by the firing of the guns in and around the palace yard; and by seeing the people rushing from the weekly market, the women taking down their hair as they ran-the Malagasy sign of mourning on the part of the women. All were rushing home to hide or to protect their property, as they feared there might be a 'rising'; but the new queen was immediately proclaimed, and all passed off quietly. Rànavàlona II was born in the year 1829, and ascended the throne on April 2, 1868.

The new queen was proclaimed on the forenoon of the day on which her aunt died. She had been known as Razàfindràhèty, but assumed the name of Rànavàlona III. She was born on November 22, 186I, and was baptized at Ambòhimànga on April 5, 1874. She received the elements of her education in a village school in a country district from one of the London Missionary Society teachers. She afterwards became a scholar in the Congregational school of Ambàtonakànga, the city church of which her father and mother became members. She was for some time in the Friends' High School for Girls, taught by Miss Helen Gilpin, and afterwards for some years was a scholar in the London Missionary Society Girls' Central School, taught by Miss M. T. Bliss. She was a member of the palace church. She had been married for some time to a relative of the queen, called Ratrimoàrivòny, who died in the early part of May, 1883. Her accession 
gave great joy to the Christian portion of the community.

At her coronation on November 22, on the great plain of Imàhamàsina-the Champ-de-Mars of Antanànarivo, where in former times proclamations against Christianity had often been made-her throne was set up. It was covered by the memorable canopy under which her aunt had been crowned in I868, with the words: 'God with us, ' 'Glory to God,' 'Peace on earth,' 'Good will to men,' round the cornice. On her right was a small table on which lay a large Bible. In the first paragraph of her speech she acknowledged that God had given her the kingdom. In the second she said that she hoped the blessing of God might rest upon her people. In the fourth she said: 'My desire from God is to benefit you ... and govern you in righteousness.' Again she explicitly declared that she placed her kingdom under the protection of God: 'For I know,' she said, ' that the kingdom which is governed in dependence upon God is strong and progressive.' . . . 'Remember,' she added, 'that it is righteousness alone that exalteth a nation.' 'The fear of the Lord is the beginning of wisdom.' She concluded by saying: "Whoever forsakes the path of righteousness walks in darkness '.'

In $1883 \mathrm{I}$ thoroughly revised my translation of the shorter Catechism with proofs, and reissued it at a penny per copy. Some r6,ooo copies have been sold. It was taught in the London Missionary Society normal and high schools in the capital, while latterly in the French normal and high schools, and in the local preachers' and teachers' classes of the Bètsilèo Mission it has also been taught. 



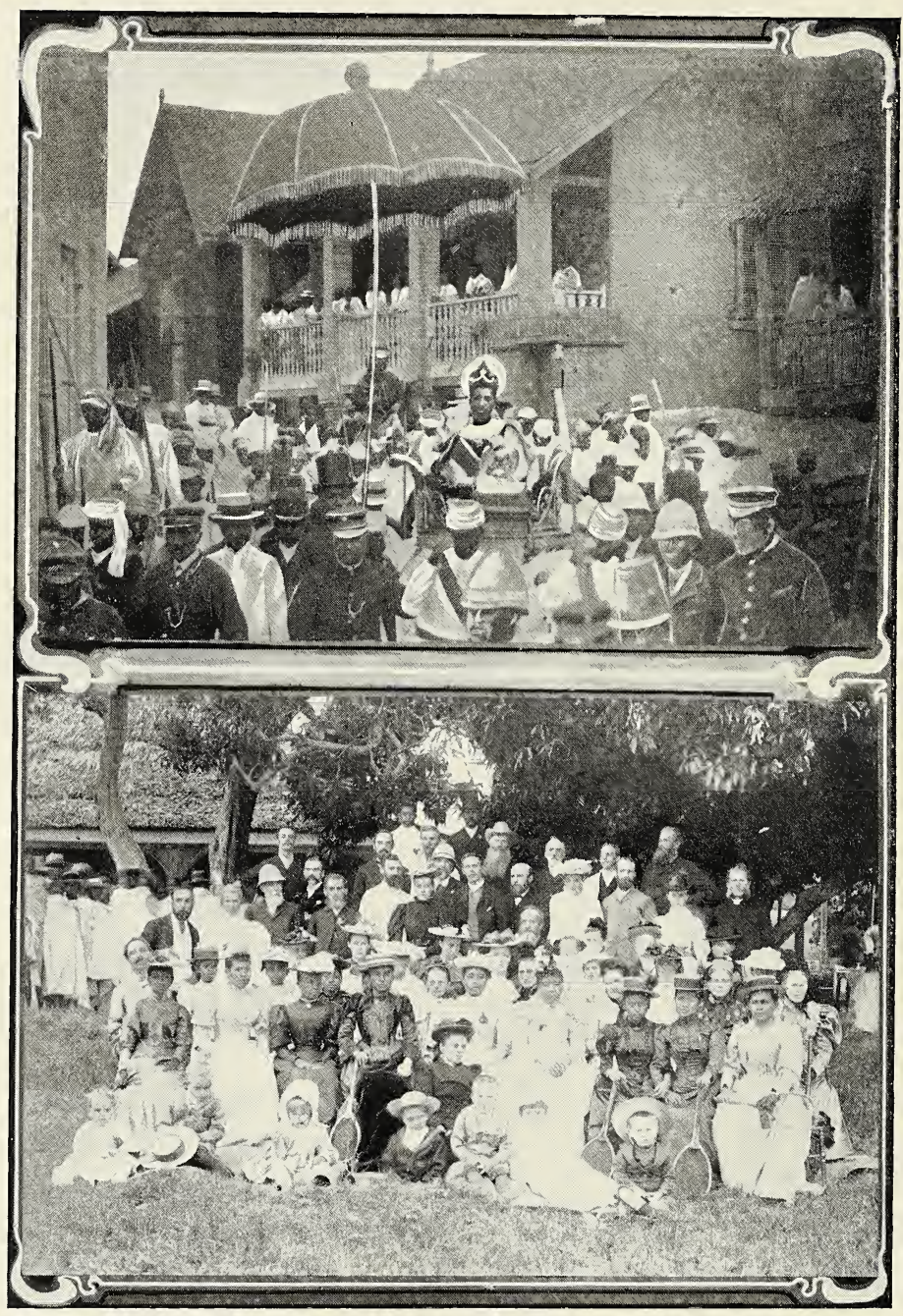

THE QUEEN OF MADAGASCAR ON THE WAY TO THE LAST REVIEW. A GARDEN PARTY AT THE QUEEN'S GARDENS. 
During the war messengers came to the capital from the chiefs of the various tribes to assure the queen of their allegiance to her, and among others there came representatives of the great Sàkalàva tribe, or series of tribes, who inhabit some 600 miles of the west side of the island. These messengers were very much astonished at the state of things they found in the capital. They found the Hovas living, not, as they themselves did, in huts of mud and wattle or in miserable apologies for huts, constructed of branches of trees roofed with leaves or grass, but in beautiful brick houses which in their eyes were furnished luxuriously. They found them too professedly sitting at the feet of Jesus Christ, clothed and in their right mind, worshipping God the Creator. They saw too that even the household slaves were better fed and clothed, more intelligent, and living in more comfortable houses than even some of their own great chiefs and petty kings. They came to our churches, heard the preaching, saw the schools, and visited the mission hospital. They were delighted also with the kind reception and treatment which they received on all sides, from the queen and prime minister downwards. Finally they asked: 'What is the meaning of all this change, and what has brought it all about; for this is not as things were in the days of your forefathers or even as they were a few years ago?' They were told that ny fivavàhana, 'the praying,' had brought all the changes, and doubtless they returned home to tell of all they had seen and heard, and how kindly they had been treated. They would also report about the wonderful and wonder-making ' new religion,' which had wrought such changes on men and things. I do not doubt that the outcome would have been an appeal from those tribes for missionaries to teach and tell them about the wonder-making fivavàhana, 
praying or religion, but for the troubles that arose, and ended as all now know.

As Tàmatàve was blockaded for nearly three years we received no mails for the first six months after the war began, while flour, sugar, and all imported provisions rose to famine prices. We sent letters to the various ports, in the hope that they might be picked up by H.B.M. ship 'Dryad' or some passing vessel, and carried to a British port. To the disgrace of some Mauritius merchants be it told-in all probability French-Creoles - the captains of their vessels were forbidden to take mails or passengers to and from Madagascar. One British captain-I wish I could give his name-dared to disobey orders, and give a passage to three stranded members of our mission to Mauritius on their way to England, and was discharged by his owner for so doing on his arrival in port.

Our letters lay at Tàmatàve for six months, until the British government demanded that they should be given up. They were all opened, our papers and magazines were burned, and the London Missionary Society annual warrant of expenditure for the Imèrina district committee was never forthcoming. Perhaps it was supposed by its non-arrival the Methodist missionaries-who were believed to be inciting the Hovas to resistancewould be starved out; but we simply borrowed the money needed, and quietly went on with our work, which flourished and made progress, notwithstanding all the troubles.

Meetings to pray for peace were established at centres, and it was most pathetic to listen to the Malagasy pleading for their invaders, that God would bring them to a right mind, and take them safely home to their own land. The conduct of Captain Johnstone of H.B.M. ship 


\section{Blockaded}

'Dryad ' during that trying time was beyond all praise. $\mathrm{He}$ called at the various ports for our mails, taking away any British subjects who wished to leave the island, sent up letters and papers to us in the interior, and protected and defended British subjects and interests in a way and in a spirit for which he ought to have been made an admiral; but instead of that-as we afterwards learned, to our sorrow-he was censured. 


\section{CHAPTER XIII}

\section{BIBLE REVISION AND 'AN OLD DISCIPLE'}

'In the latter days it shall come to pass, that the mountain of the Lord's house shall be established in the top of the mountains, and it shall be exalted above the hills; and peoples shall flow unto it.'MICAH iv. I.

I BECAME a member of the Committee for the Revision of the Malagasy Bible in 1883 , and remained a member for four years-till the finish of the work. This duty proved most interesting and enjoyable. The revision was not the triumph that the translation made by the first missionaries had been-partly, I think, because it had been overlauded, which led the people to expect too much from it; partly because, while a more correct and literal translation, it was, in consequence, not so idiomatic, and perhaps because the paragraph form in which it was printed was not so popular, at least in the schools, as the old form in verses. It occupies much the same place among the Malagasy that the Revised English Version does among ourselves, with this difference, that it is the only version which the Malagasy can now obtain.

The work of the revision led us to think more highly than ever of the splendid work done by the early missionaries during the thirteen years they were in the island. Reducing the language to writing, founding churches and schools, making those noble-one might almost say marvellously idiomatic-translations of the 


\section{Word-moulding}

Bible, the Pilgrim's Progress, and other books, and so planting Christianity in the hearts of the people that it could not be uprooted, was a work that has never been surpassed in any mission field, and seldom, if ever, been equalled. There were certainly giants in the mission field in those days; but, as we have lately seen, the race has not quite died out.

We saw in the work of revision some fine examples of 'the word-moulding power of Christianity.' To give a few of them: Fitòndràntèna meant carriage of the body, or one's self; hence tsàra fitòndràntèna meant good carriage-as we would say, a lady, or a person of good carriage-debonair; but it has come to mean good conduct, hence moral character. Fièritrèrètana, which meant the faculty of meditation, has come to mean conscience. Fàhadiòvana, an abstract noun from root dio, whence adjective madio, clean, pure, hence white, meant cleanness, purity or whiteness of, say, a garment, or a cotton làmba (plaid); it has come to mean moral purity (a virtue formerly unknown in Madagascar, as it is in all heathen lands), as fàhadiövampanainy, the purity or whiteness of the soul. Hàmasinana and fàhamasinana, from root hàsina, probably connected with hàsina-if not really the same word-the sacred tree, meaning sacredness, has come to mean holiness. Fanàtitra meant a present, a gift; it now means, and is used almost exclusively for, a religious offering. Thus: Fanàtitra nòho ny òta, a sin-offering, lit. an offering on account of sin. Fanàtitra alàtsa-drà, a sacrificial offering, lit. an offering in which there is shedding of blood. Fandràisana meant the time or place of receiving, now Ny Fandràisana stands for the Communion. Fàhaverèzana, abstract noun, meant disgrace, of an officer or an official, or any one who 


\section{Bible Revision and 'An Old Disciple'}

lost their position, now stands for the loss of the soul. Fanàhy, if derived from the root àhy, which means care or solicitude, anxiety, would mean the faculty of care, solicitude or anxiety; but if, as seems more probable, it is derived from the root nàhy, which signifies will or intention, it would mean the faculty of will, or choice; but it has come to mean (if it did not always mean that, in a vague sort of way at least) the soul, the spirit. The existence of a soul or spirit, as distinct from the tèna, body, and nòfo, flesh, seems always to have been recognized; for so much was certainly implied in the belief of the people in ghosts, matoatio, and àmbiròa, shades, or second selves. Radàma I's father when dying said: 'It is my body that will be buried, but my (fanàhy) spirit will be with you to whisper to you words of counsel.' Fanàhy vàovào is a new spirit, which a Christian receives at conversion. Tsàrafanàhy is a good spirit, hence Lehilàhy tsàrafanàhy is a good man, lit. good-souled man. Ràtsifanàhy is a bad spirit, hence wicked.

The late J. Andrianaivoràvèlona-the Spurgeon of Madagascar-was a member of the Bible Revision Committee for twelve years, and did more for the idiomatic tone of the new translation than all the others put together. He was not only the orator of the island, but was also a genius in his knowledge and use of the language, and a giant in physical strength. He came into the committee looking very tired and exhausted one morning. Our chief reviser said to him: 'You look very tired and worn-out this morning, Andrianaivowhat's the matter? what have you been doing?' He answered: 'I am tired; for I have not recovered from my Sabbath labours yet.' He was asked what he had done on the Sabbath, when he replied that he had preached 


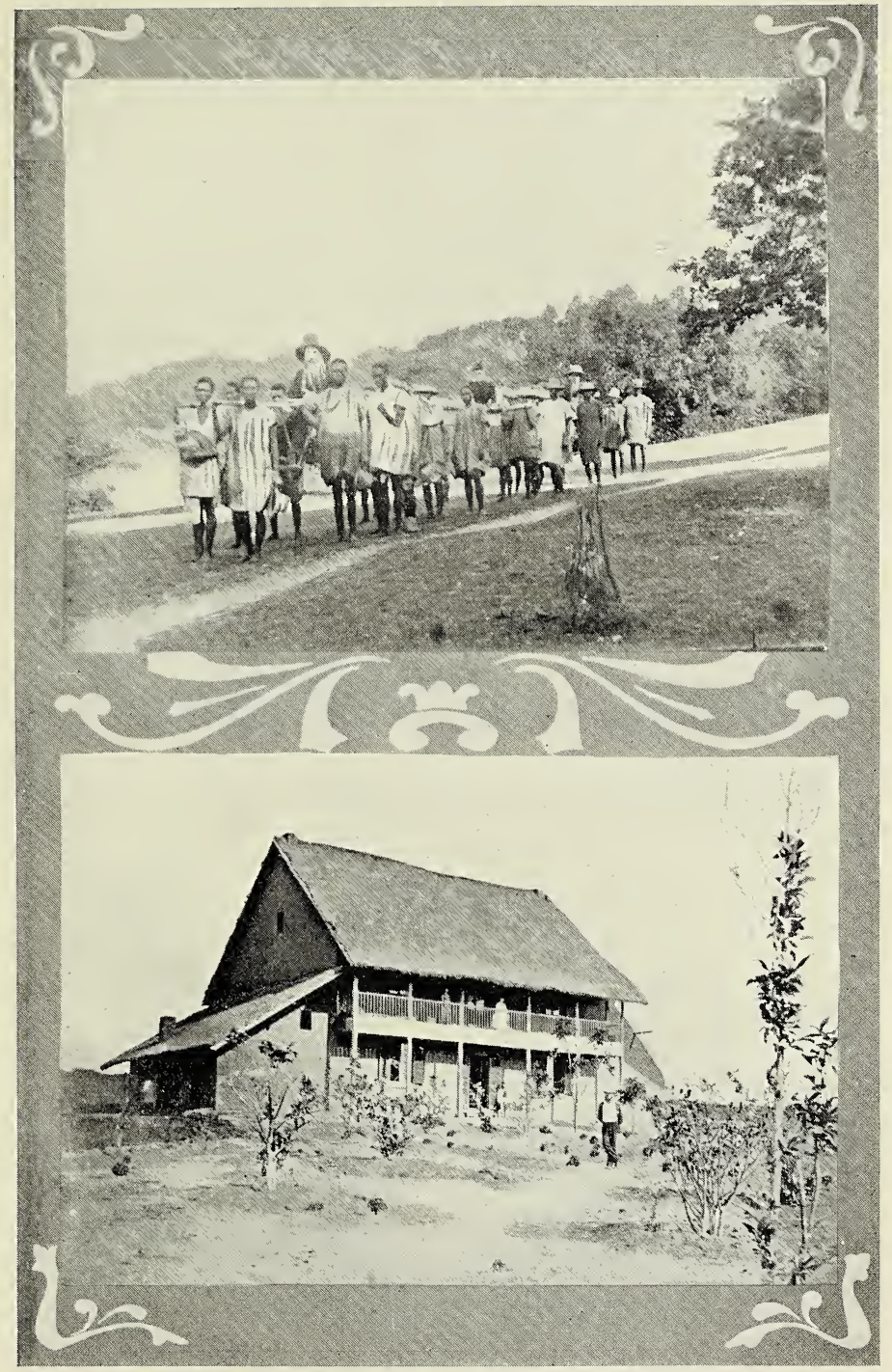

THE AUTHOR TRAVELLING IN PALANQUIN. THE MANSE AT FIHAONANA. 

fourteen times! He had left the capital at five o'clock, had his first service at six, had food prepared for him at various centres, and continued services till seven o'clock at night-fourteen in all--little wonder if he was tired. I have heard all the great British preachers of the past forty years; and I would as soon have heard Andrianaivo as any of them. I have seen him keep an immense congregation spellbound for an hour and twenty minutes. When at his best, the force, fervour and enthusiasm of the man were magnificent, and carried all before them.

On Thursday, July 30 , $188_{5}$, Razàka, the pastor of our old station church at Fihàonana, was called to his rest and his reward. Few men were ever more missed or more sincerely mourned than he was. He was the best and noblest Malagasy Christian pastor I ever knew, and one of the truest and most sincere men I ever met. 'He was a faithful man, and feared God above many.' He was loved and looked up to by his fellow countrymen in a way, and to an extent, I have never known in the case of other Malagasy pastors.

A tall, handsome, noble-looking old man, he appeared like a king among men, with his 'silvery locks waving in the breeze,' in his case a veritable 'crown of glory.' You felt, when you met him, that he was no ordinary man. 'Nature has written a letter of credit upon some men's faces,' says Thackeray, ' which is honoured almost wherever presented.' It was so with dear old Razàka, for it might almost have been said that 'his face was his fortune'; for, although he had no 'face like a benediction,' yet honesty was so stamped upon its every feature that you had but to see it to feel that its owner was one of God's noblest works-an honest man.

One could not help being drawn, as by some magnetic 


\section{Bible Revision and 'An Old Disciple'}

influence, towards the good old man. I well remember our first meeting, a few weeks after our arrival at Antanànarìvo. We could not exchange a word, we could only grasp each other by the hand, and look in each other's faces; but I felt, as I looked in that transparently honest face, that here was a true man; and my heart warmed towards him, as a man who had done, and said, and suffered much for the cause of Christ in Madagascar; and the longer I knew him the more I loved and respected him. We drew to each other from the first. We were fellow labourers in the vineyard of God for many years, and the fastest friends to the day of his death. He was ever a tower of strength to me. I hardly know how I could have got through one-half of the work I was privileged to do in Vònizòngo but for the help and encouragement I received from Razàka. 'He was a good man, and full of the Holy Ghost and of faith.'

Napoleon Bonaparte said: 'Conquest made me what I am, and conquest must sustain me.' It was the grace of God, and the conquest it made of him heart and soul, that made Razàka what he was, and sustained him to the end. He had a deep and passionate love for his Bible: I have seldom met any one who knew it as he did, for he seemed to know it from Genesis to Revelation, and 'the word of Christ dwelt richly' in him, 'in all wisdom and spiritual understanding,' while he strove to live up to his light and to the testimonies of the Book he so dearly loved.

Once in a Bible-class I said to him: "Supposing some one were to say to you, Razàka, that the Bible was not trustworthy-what answer would you give him ?' 'No one would be so foolish as to say anything of the kind,' he replied, 'except some foolish Malagasy, who 


\section{The Bible at Work}

did not know what he was speaking about. I should tell him to hold his peace until he knew what he was talking about.' 'But,' I said, 'suppose some Vazàha (European) were to say such a thing to you-how would you answer him?' It was difficult to get the good old man to imagine any European who could doubt or deny that the Bible was the Word of God. 'Well,' I said, ' just let us suppose such a case for the sake of argumentI would like to hear how you would answer him.'

'Well, sir,' he said, 'I know that God made me, and I feel quite certain that whoever wrote the Bible knew a great deal about me; for it describes my state and wants as a sinner so exactly, that no one who did not know me could have pictured them as the Bible does. Now I know that no Malagasy wrote the Bible, or could write it-you Europeans brought the book from over the sea; and what European there knows anything about me? You know more about me than any other European, but you did not write it; for the Bible was here years before you came. The way I explain it, sir, is this: God made me, and "holy men of God" wrote the Scriptures, "as they were moved by the Holy Ghost "-and that is how I find my low and lost estate and my wants so pictured there.'

'Yes,' I said, 'that is very good; but suppose the European were to say: "My good old man, that may satisfy you, but that proves nothing, and certainly does not prove that the Bible is true or the Word of God. It is only a tissue of cunningly-devised fables, legal fictions, and falsehoods." What would you say then, and how would you answer that, and prove that the Bible was trustworthy and the Word of God?'

'The Bible a fable, full of fictions or falsehoods, sir, he said, ' that can't be; for the work it has already done 


\section{Bible Revision and 'An Old Disciple'}

in the land proves that it must be the truth of God; I don't know what your European falsehoods, fables or folk-lore may be like; but the Scriptures are very different from our Malagasy ones. Our fables and folklore are filthy trash, and our lies as black as they can be made. I am an old man, but I never in my life knew a lie do any good. As our Malagasy proverbs say: "A falsehood may be very fat when it is uttered, but it becomes very lean when confronted." "A lie is like the early rice-it serves the occasion, but does not hold out." ' No, sir, he said, "if we think of the good that the Bible has already done in this country, that seems to me to prove it to be God's book; for no book could have done what it has done in this land unless it were the Word of God. What was this country before the Bible came? The people are not nearly so wise and good yet as we hope they may become; but a great change has come over them, and it is the Bible that has wrought that change. I remember what the past was, and I know what the present is, and so can compare them. The book that has brought this great change about cannot be a mere tissue of fables and folk-lore, fictions and falsehoods-it must be the Word of the Almighty to have wrought the miracles it has wrought in the land, and to have done the good that it has done. I could not believe that any collections of mere fables and folk-lore, or fictions and falsehoods, could be the cause of all the good that has been done.'

Razàka was quite right: the Bible is its own best witness, and the miracles it works, both at home and among the heathen, the best proof of its divine origin.

Razàka was born at Fìhàonana, Vònizòngo, probably about the year 1814 , so that he had reached the 'three score years and ten' before he passed away. He was 


\section{Razàka's Early Days}

the only child of his parents, and hence was spoiled by them, and grew up a very wayward, wilful, wicked lad, the terror of the village and neighbourhood, and a great authority on heathen charms, especially love-philtres. His father being one of the head-men of the district, numbers of the people visited him to consult him with regard to district affairs; but such was their terror of the son, even as a lad, that they would not venture to enter the village if they knew he was in it.

As he grew up to manhood, his delights were cockfighting, bull-fighting, and diamànga, a kicking game. Some years after he was married, as his wife had no family, his father pressed him to take a second wife; but he declined to do so, not from any high or pure motives; but simply because he disliked the idea of having two wives. He came to be on friendly terms with several of the public criers, the men who used to proclaim in the fairs and district markets the royal proclamations, laws of the land, and edicts on the affairs of the kingdom, \&c.; and, being a born speaker, he soon gained great power and made money. He was restless, however, and early got weary of the life he was living. God was preparing him for better and nobler work, although he knew it not.

About 1833 some of the early missionaries visited Vònizòngo, and a school was begun at Fihàonana. Among the first scholars was a son of the chief, who was a friend of Razàka's. One day this lad told him about the things they learned at school, and, among other things, told him the story of Adam and Eve. The following day he was told something that surprised him very much more than that, and arrested his attention as nothing before had ever done. He was told that God created the world and all in it, and that, although it is appointed 


\section{Bible Revision and 'An Old Disciple'}

once for all men to die, God would ravse them to life again at the last day. Such truths laid hold of his heart and mind, agitated him, and set him a-thinking, and ultimately led him to attend the school himself, in order that he might learn more about the new Fivavàhana-religion. Being sharp, he very soon learned to read, and to the end of his long life was a beautiful reader, and a most fluent and gifted speaker.

When the chief's widow (who was the first convert to Christianity in Vònizòngo, and whose eldest son, Ràmitràha, the young chief, was afterwards burned at Fàravòhitra, Antanànarìvo, for his faith in Christ) heard that Razàka had entered the school, and had so quickly learned to read, she said to him: 'I am so glad to hear that you have gone to school and learned to read, and that you will now be able to study the Word of God. Now don't be wilful and wicked any more-for the Word of God forbids such things.' These few words from that good woman seem to have done more to break Razàka's proud spirit and humble him than all that had ever been said to him before. He obtained possession of a copy of the Psalms in Malagasy, and a translation of a catechism of the main doctrines of Christianity by the late Dr. Russell of Dundee, and of the very small hymn-book the converts then had-all of which he greatly prized. $\mathrm{He}$ afterwards obtained possession of several portions of the Scriptures.

Razàka retained a great affection for the memory of the early missionaries, especially for that of the Rev. D. Griffiths. I remember once calling to see him, and finding him sitting on the floor of his room writing, and by his side was a cut-glass ink-bottle, with a brass cover which screwed down on to the mouth. I asked him from whence he had obtained such a nice ink-bottle; and 
he answered that Mr. Griffiths had given it to him as a parting present. Wondering how he regarded such presents, I said to him: 'You had better let me buy it from you, as it is just the sort of ink-bottle I want to carry with me on my journeys, and you can easily get another to serve your purpose for all the writing you have to do.' He made me no answer, but went on to talk about something else. I returned to the subject, but he again evaded giving me an answer. I then said: 'You had better let me buy that ink-bottle, Razàka '; and he answered: 'Well, sir, if you really want it I will make you a present of it, but as I received it from Mr. Griffiths as a keepsake, I will never sell it.' 'No, my friend,' I said, 'I do not want your ink-bottle; you keep it, I was only joking. I am glad to find that you still retain such an affection for your former missionary friend, that you will not part with his gift for money.' Yes, Razàka was a born gentleman - one of Nature's noblemen, who could never stoop to a mean thing.

Some three years after the time mentioned above, the praying was prohibited, persecution began, and death was made the penalty of worshipping 'the white man's ancestor Jesus Christ '; but Razàka was left unmolested for some years, and many drew to him for counsel and prayer. This was especially the case after the martyrdom of his chief, Ràmitràha, as Razàka got his big Bible and continued his midnight prayer-meetings.

Shortly after this he was drafted into the army, in which he had to serve down to 1876 without a penny of pay, and having many a pound to pay to his officers; for under the Hova régime, the officers lived mainly by blackmailing their men and by loot; hence tribal wars were very popular, as they were simply plundering expeditions. His father died the year he was drafted 


\section{Bible Revision and 'An Old Disciple'}

into the army, and in those days a funeral was a very expensive affair indeed to relatives, so that it was a time of trouble to him; but, notwithstanding his troubles, he was the means of leading many to the Lord, of comforting and supporting others, and of building others up in the faith.

The idol-keepers were continually at war with him, as he refused to honour the gods of the ancestors, and even denounced them, and as the land was full of idols and idol-keepers then, he was heartily hated by all who had vested interests in that class of property. He was regarded as 'a setter forth of strange doctrines,' a man who was bent upon ruining his country by uprooting the religion of his forefathers. Such was the hatred of the heathen party to him, that the wonder is they did not make an attempt on his life. His wife was taken from him by her heathen parents, and he was watched and followed when he left his hut at night to visit some of the converts, or to go to one of their midnight gatherings for prayer, as it was thought that he went out during the night to rifle the tombs-a heinous crime in Madagascar, and held worthy of death. Treasures were often buried with the dead, and parties caught in the act in pursuit of them were summarily dealt with. Many a night, as he learned afterwards, did his enemies lie behind the tombs, with their spears ready to transfix him if he had approached them, even if only to take a seat, as it would have been taken for granted that he did so for no good purpose. One night, while he and a few others were having a midnight gathering for prayer, and he was offering prayer, a stone was flung into the hut, which struck his eldest son on the head, and laid him bleeding and senseless on the floor. When the father ceased praying, and a light was procured, he 


\section{A Midnight Baptism}

found his son lying seemingly dead, but he had only fainted.

In the year 1849 the persecution became much more severe, and on March 28 of that year, Razàka, along with many others, was sold into slavery, because he was a noted leader among the 'prayers.' As he was purchased by some of his relatives, his case was not so hard as that of many others. Some who had made profession of Christianity were found faithless when the hour of trial came; but he and many others stood firm to their faith. The converts in Vònizòngo and the neighbourhood, who had proved faithful, still met in his hut in Fihàonana for their midnight prayer-meetings, and for the reading of the Scriptures.

Razàka and his wife were among the first of the converts from Vònizòngo who were baptized after the persecution began. They were baptized at a midnight prayer-meeting in the house of Rafâravàvy one very dark night, while the rain descended in torrents, the lightning flashed, and the thunder roared. Her house was at Imarivolànitra, near to the spot on which the London Missionary Society printing-office now stands, and within gunshot of the palace. It would have been death to the whole party if they had been discovered In 1850 they were received into church fellowship, and for the first time partook of the Lord's Supper; and from that time Razàka became a more prominent member than ever of the persecuted band of Christians, with whose lives and fortunes the future of the Church of Christ in Madagascar was bound up.

Razàka became so noted among the 'prayers' in Vònizòngo, that the queen sent officers to arrest him and bring him to the capital. He had notice of their coming, and escaped. He got back to Fìhàonana one 


\section{Bible Revision and 'An Old Disciple"}

dark night and into the cave. He was able to let his wife know that he was there, and she took him food during the night. He lay hidden in that cave-the small-pox hospital-for two years, his wife taking his food to him during the night. He lay near the mouth of the cave during the day reading and re-reading the Bible-which was hidden there-until he seemed to have got the whole book by heart. As he was thus out of sight for two years, it was thought that he had escaped to the Sàkalàvas, and been murdered by them as a Hova spy; and so search for him was given up. Afterwards, in order to keep him and a few others of the more prominent 'prayers' in Vònizòngo out of danger, Prince Rakòto Radàma (afterwards Radàma II) sent Razàka and other five down to Bàly on the west coast, under the pretence of seeing what the French priests were doing there; but really to get them out of danger, in case their zeal for the propagation of the faith might attract the notice of the queen, and cost them their lives.

They started for Bàly on July 4, 1854 , suffered great privations on the way-were four days and nights without water, four of their number going mad in consequence-and after all they never reached Bàly; for they were seized by the Sàkalàvas as Hova spies, tied up, and taken to the large Sàkalàva town of Namòroka. The old mode of tying up prisoners, with small cords twisted round their wrists, was a most painful and cruel method; and the cords were twisted more tightly round Razàka's wrists, until they cut into the flesh, as a sort of honour, he being treated -as he really was-as the leader of the party. Shortly after being caught they were sold as slaves to some Arabs, who, in their turn, sold them to a French trader, 


\section{'In Perils among False Brethren' 261}

who carried them to Nòsibè, where they arrived on September 25, 1854 .

At Nòsibè they found a Jesuit priest, who had been in Antanànarivo, and to him Razàka wrote, asking him to buy them, which he ultimately did. He knew they were Protestants, but he probably hoped by freeing them to make Romanists of them, and to be able to make good use of a man like Razàka. In this he was disappointed, for Razàka and one of his companions refused to change their religion. At this the Jesuit was wrathful. He first tried to win them over, then he tried threatening them, and at last he sent them as slaves to Réunion. Their case was very pitiablestrangers in a strange land, free men and yet treated as slaves. No doubt they would have fared far better if they would have consented to change their religion and become Roman Catholics; but they set their faces like flint against doing so, and they had to suffer for it. On March 5,1855 , they were put on board ship to be taken to Réunion, which they reached on April I. The scenes that Razàka witnessed on board the slave-ship and at Nòsibè dare not be described.

At Réunion the Jesuits tried hard to persuade Razàka to marry one of their Catholic girls; but he refused, as he said he had a wife in Madagascar. They said: 'Very likely she has gone all wrong by this time, or, regarding you as dead, has married some one else.' He answered that he did not think that probable; but in any case he would wait to see before taking another wife. They wanted to rebaptize him. He told them he had been baptized, but if it was likely to do him any good, he had no objection to being done again. They said his Protestant baptism was of no avail, as it had not been performed by a priest. He asked in whose name they 


\section{Bible Revision and 'An Old Disciple'}

baptized, and they replied, in the name of the Father, the Son, and the Holy Spirit. He said: 'It was in Their name that I was baptized, and I don't see that being baptized again in Their name will do me any good '; and so he refused to submit to a second baptism.

When they found that they could make nothing of him, and there was a danger of his even turning some they had from the Roman Catholic faith, their treatment of him changed. As he knew his Bible well, had a good memory, and the gift of exposition, when he and the others were shut up in the dormitory at night, he used to recount to them the stories of the Old Testament, and the parables of the New, repeat and explain the meaning of hundreds of verses in the Gospels and the Epistles, until the faith of the listeners in the teaching of the Jesuits began to be greatly shaken. When this was discovered, the anger of the Jesuits knew no bounds; and, as they had no hope of ever being able to make a convert of him, they determined to get rid of him and his companion. On learning this, Razàka and his friend begged to be sent to Mauritius, to be sold to the Rev. Mr. Le Brun, the Protestant missionary, afterwards pastor there; but they would not do that. 'No,' they said, 'we shall send you back to Madagascar, you ungrateful creatures.'

Accordingly, on March 20, 1856 , the two were shipped off to the Island of St. Mary's, which they reached after a voyage of three days, and from there they got over to. the mainland, and started up country for home, where, after having been away nearly two years, they arrived on April 7, much to the surprise and joy of their wives, children, and companions.

On July 31, I 86r, Rànavàlona I died, and persecution was at an end. All were then free to worship God 
as they pleased. In $186_{3}$ a building was erected in Fìhànana, but it was soon found to be far too small for the numbers who came together. After a time small churches were formed, and buildings erected in most of the other large villages. Razàka founded some forty of these small churches in the Fìhàonana district in Vònizòngo. He was often away from home for weeks, and even months, teaching, preaching, and founding churches. All this was a pure labour of love on his part; for he obtained no recognition of his work in any way, except that the people looked up to him as their father in the faith, and the God-appointed apostle and 'father and mother' of the district.

The late Dr. Mullens met with Razàka when in Madagascar in 1873, and, in his Twelve Months in Madagascar, he says: 'Of Razàka, the pastor of the church at Fìhàonana, Mr. M. spoke much. It was a great pleasure to Mr. Pillans and myself to see this good man : to talk with him of the hard days of trial; and to hear from his own lips the story of the sufferings he had endured. He told us of the meetings which the fugitive Christians held for worship and mutual help. They used to come long distances to such meetings; tracts were lent from one to the other, as a tract could often be carried and hidden away, when a Bible or a Testament could not. Parts of the New Testament were lent about, even to single leaves; and leaves of the hymn-book and the Pilgrim's Progress. He said they used often to long for a rainy night, in order that they might be able to sing. He showed us the underground passage, beneath the floor of his huts (from the one rice-pit to another, and from that out to the hollow ditch), by which, when the soldiers came to search, the inmates and visitors could escape. $\mathrm{He}$ accompanied 


\section{Bible Revision and 'An Old Disciple'}

us to a pile of immense boulders (in the circle formed by them the persecuted Christians met for worship on the Sabbath mornings, during lulls in the persecution), and showed us the "Cave" beneath the big boulder, into which they used to creep to have a prayer-meeting, and in the dark corner of which the Bible was hid for so long. He brought vividly before us the sufferings and persecutions which his heroic brethren and himself had endured; and in him we realized something of the power of that faith by which all had been sustained. Few finer bodies of Christians have been won for Christ by modern missions than those faithful men and women in Vònizòngo.'

At my request, Razàka wrote an account of his Life and Times, but he stipulated that it was not to be published during his lifetime, in case it might get him into trouble with the government. It was published by instalments, first in Good Words, and then as a small booklet, hundreds of which have been given away as school prizes.

I had the satisfaction of seeing my dear old friend four days before his death. I was in the neighbourhood of Fihàonana, on my autumnal tour through my district, and went over on the Sabbath morning to visit him and our other friends at our old station, and to preach for them. I found him prostrated with malarial fever, but had no idea he was so near home-so near hearing the welcome, 'Well done, good and faithful servant!' I was never more struck with the calm Christian resignation of the man than I was on that occasion. There he lay, sweltering in the fever-but not a murmur passed his lips. His honest face beamed amid his sufferings, as if light from the 'better land' was already falling on it. He expressed his sorrow at being found prostrated with 
fever, when his friend had come so far to see him, as also his deep disappointment at not being able to go to church to hear me preach. He passed quietly away the following Thursday, July 30 .

'On the Saturday previous, he told us,' said one of his fellow pastors, 'that he would like to preach next day' (although it was not his turn to do so, the first Sabbath of August-the Communion Sabbath-being his turn). His fellow pastors agreed to his wish; but he was never able to carry out his intention; for the following day found him suffering from fever and pneumonia, and of this he died. The day before his death he said: 'We do not know at all what shall be the day of our death.' About the middle of the day on which he died he said: 'Prayer is the breath of the believer,' and also: 'Jehovah will answer prayer.' He asked them to read Isaiah lxi to him, 'The Spirit of the Lord God is upon me, \&c.' He asked for his fellow pastors to be called, and they came and prayed with him. His wife and they asked how he felt, when he replied: 'There is only a very little (life, or way' to go) left.' Just before he died he said to his daughter-in-law: 'Don't look at me any more!' perhaps he thought she would be frightened if she saw him expire; and so about three o'clock in the afternoon of Thursday, July 31,1885 , he passed to his rest and his reward.

The death of Razàka was a very great loss to the mother-church at Fìhàonana, and to all the churches of the district, a far greater loss than the loss of their missionary : for he was ' father and mother' to them all ; and they were all very deeply distressed at his death. They realized that a prince and a great man had fallen in the Church of God; and although they did not sorrow 'as others who have no hope,' for they knew 


\section{Bible Revision and 'An Old Disciple'}

that Razàka had only gone on a little ahead to join the general assembly and church of the firstborn, who are written in heaven, and the spirits of just men made perfect. But, feeling that in him they had lost a father and a friend, their distress was very deep, the deeper that there was no one like him left to help and guide them.

$A$ vast multitude assembled at his funeral, and the signs of grief were the greatest and deepest ever seen in Vònizòngo. His grave is on the hill-side, to the east of Fihàonana, quite near to the 'Cave' in which he and the Bible were so long hidden.

Shortly after Razàka died another Vònizòngo veteran passed away, in the person of Andriantsehèno, the pastor of Ankàzobè. He died on Sabbath, Oct. 25 ; and just before he expired, he said: 'Say good-bye to Mr. Matthews and Mr. Cousins, the elder, for me-for I am going!' and shortly afterwards he ceased to breathe. 



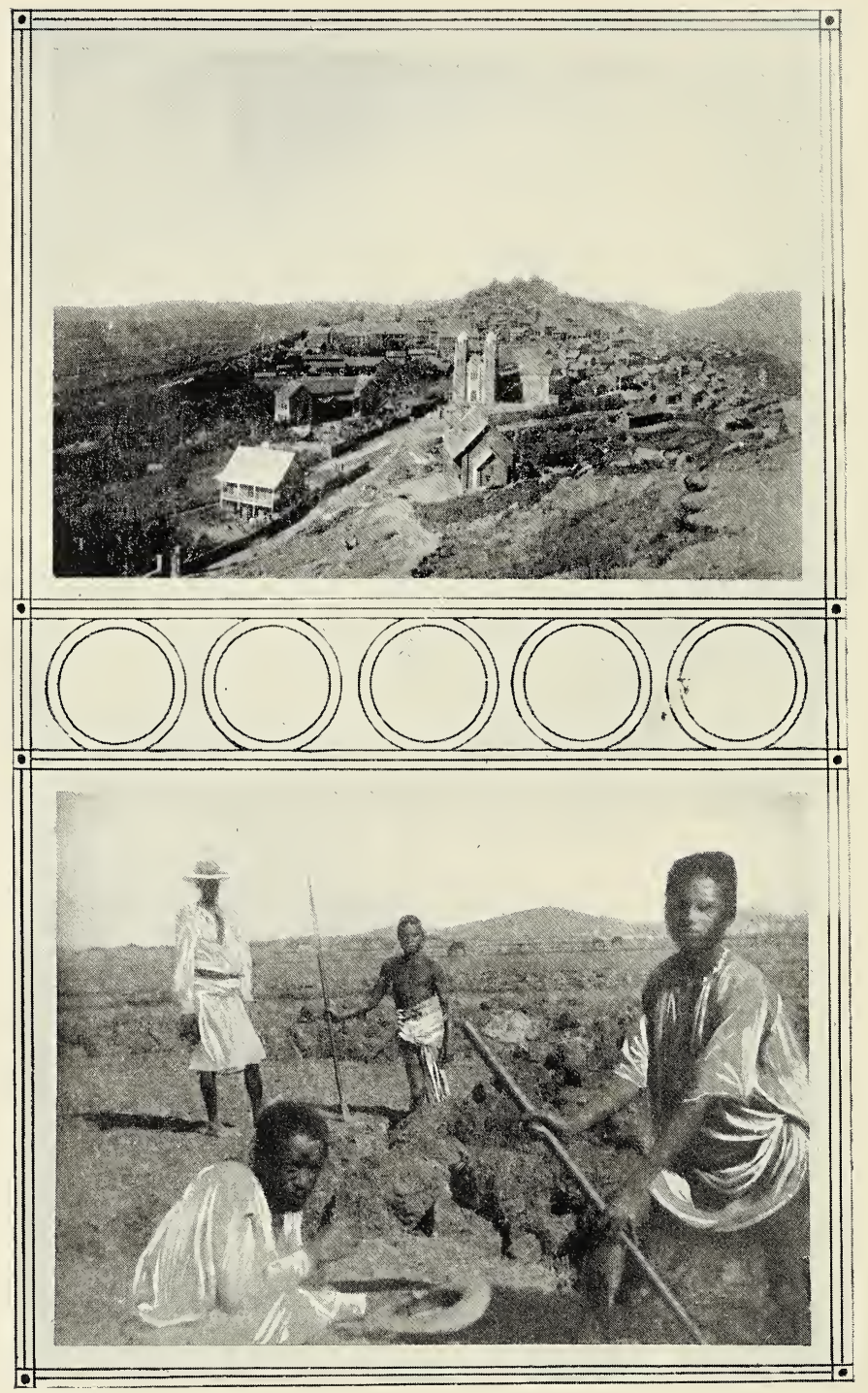

FIANARANTSOA, CAPITAL OF BETSILEO. MALAGASY WORKING THE SOIL. 


\section{CHAPTER XIV}

\section{THE LIGHT EXTENDING}

'All the ends of the world shall remember and turn unto the Lord: and all the kindreds of the nations shall worship before Thee.'-PSALM xxii. 27.

I WAS sent to visit the Bètsilèo Mission, a hundred miles to the south of Antanànarivo, during 1885 . I was away for seven weeks, and returned rather exhausted, for I was worked very hard indeed while in the south. I enjoyed my visit, however, and returned refreshed in spirit and glad at heart for what I saw being done in Bètsilèo. Like Barnabas of old, when I came and had seen the grace of God (or rather the fruits of that grace) I was glad and, like him, I exhorted them all, that with purpose of heart they would cleave unto the Lord. I was very specially interested in the work at Ambòhimàndròso. I found young men there better acquainted with the Bible, biblical geography, and the shorter catechism than I have found anywhere else. It was refreshing to witness what Christian zeal can accomplish.

My visit to the Bètsilèo Mission led to the institution of a most important service in the capital, after our return, namely, a special service twice a year for women. While we were at Ambòhimàndròso-some thirty miles south of Fianàrantsòa, the capital of the Bètsilèo country -I suggested to the wife of our missionary there that she and the two ladies from the capital should have 
a special service for women only, while her husband and I were having our service for the men. She was rather shy at first about having such a service, as it would be quite a new departure; but after consulting with the other two ladies it was agreed to give the plan a trial. They did so, and it was a success. On the return of the two ladies to Fianàrantsòa they bore testimony to the success of the service, and the ladies there determined to have one also, and this was even a greater success.

On their return to the capital the two ladies reported their successful services for women in the south, and at once set to work to arrange for such services in Antanànarivo at the time of the 'Union Meetings,' while the fathers, husbands, and brothers were at the men's meeting. Our A-kànga church was chosen for the service, since it was the only one which could be kept perfectly private, and the entrance could be regulated by our front gate, besides being most central. I acted as gatekeeper for the first few meetings, but the ladies were soon able to manage all by themselves. These services have been most successful throughout. The night before the first service $I$ had a hint that some young men might try to pass in, dressed as women, as there was the greatest curiosity among some of them to hear what the ladies would say to the women. If any really ever meant to attempt this they had changed their minds, as only one appeared of whom I was in any way suspicious, and as that one did not come forward, after my eye caught her-or him-there was no trouble, and all passed off well.

As we had very few things to give to the scholars of our village schools as prizes at the annual examinations for general progress, but especially for proficiency in 
Bible knowledge, except books-Bibles, Testaments, hymn-books, Good Words, and story-books-I cast about in my mind what I could get to give them instead of books as a change. I only rewarded progress and proficiency. I remembered that what I was most anxious to secure when I was a boy at school was a pocket-knife, and so I sent for a few dozen pocketknives; but they proved a failure as prizes. Why ? Because, although by that-time most of the lads had begun to wear short pants reaching to the knees, they had no pockets in them, and they felt it a foolish thing to go through the world carrying a knife in their hand! I was deeply disappointed at this failure. I determined, however, to have another trial, and this time with the girls. I sent for six dozen dolls, and made a decided hit. The girls who gained them as prizes laid them on their arms, and returned to their seats, seemingly in no way elated; but they could not long conceal their happiness over this appeal to their affections, and when they thought no one was observing them they stole fond glances at the dolls in a manner which was most refreshing to see.

The poor things had never possessed toys of any kind. The amusement of the little girls had been to catch locusts and tear off their legs, and to clap their hands in great glee when the insects beat their wings in agony, quite unconscious of the suffering they were causing to their victims. The amusements of the elder girls were less innocent; while the boys, boy-like, indulged in cock-fighting and forms of amusement of that description. In former times-and even still in the heathen parts of the island-the men indulged in a kicking game, while the upper classes, headed by the sovereign, had bull-fighting, 
With such early training it was little wonder that the Malagasy grew up heartless and cruel, and without a particle of sympathy for the sufferings of man or beast; but religion has given them with the new heart a measure of humanity, and they turn now to more wholesome amusements.

Malagasy parents are generally named after their children, not their children after them. The Bezànozàno tribe have a kind of rod, the scrapings of which they give to their children as a medicine. They also use the same rod for chastising their children. The Chinese call a beating being made to 'eat stick,' but the above practice is being made to do so in a double sense and literally!

I found I had made a slight mistake, however, even with regard to the dolls; for I had ordered wax-faced ones. This was a disadvantage, as the wax faces softened and got out of shape with the heat, and they could not be washed, which was a most important item, as few things that do not stand washing are of much use in Madagascar. The huts have no chimneys, and the smoke has to find its way out by the doors, windows, and eaves. The result naturally is that the huts become covered with soot. Festoons of it hang from all parts of the roofs, and everything is very dirty. Thus every person or thing that does long service is said to be maintimolàly, black with soot-veterans, whether military or missionary, get this name.

After two years of labour in the district I found that there was still the greatest need for the continual reiteration of the most elementary truths of the Gospel and of the fundamentals of the faith. It was a difficult task indeed to preach and teach the great doctrines of the Bible in interesting and intelligible language to a people 
who were still only in the first stages of civilization; for however great may be the force of faith apart from the mere terms of it, yet these must also be taught. To neglect these is to neglect the foundations or the pillars which support the arch. It is vain to expect it to stand without them.

The world at large-the heathen world in particularis a great spiritual hospital, full of soul-sick patients; where we see $\sin$ in all its tragic and repulsive hideousness. We find it 'the most tragic reality of our mortal life, and the greatest blot on God's otherwise fair creation.' There is no cure for it, no power that can meet and master it, except the Gospel. A late lieutenant-governor of Bengal has said: 'If the evangelical Gospel of the Lord Jesus Christ is not true we must invent it, if we are to do any good among the heathen.'

Of course we all knew very well that, at that time, among our semi-heathen people there was much mere lip and little of heart religion. It was simply profession and superficial acquaintance with a few of the truths of the Bible; but no heart love or heart reverence. It was our aim, therefore, to try by God's help to make them what they never were before, and to teach them the great principles that would guide them to a new and higher life.

We had the honour at A-kànga of initiating the movement of collections of money, clothing, and medicines for the soldiers at the front. I brought the proposal before the congregation of our mother-church, and they heartily endorsed it, and the other churches soon followed our example. We did not by any means raise the largest amount, as many of the churches were larger than ours; but ours were purely voluntary contributions. On several Sabbaths the collections were 
made in the other city congregations in the usual Malagasy way. The names of the members and adherents being called out in rotation, they were asked in the presence of the congregation how much they were prepared to give. If the amount named was thought large enough for the wealth of the subscriber the announcement was received with acclamation; but if not it was declined, and the donor was frankly told that it was not enough, and he had to raise his donation to such a sum as his fellow worshippers deemed proper. A very large amount of money was thus raised; yet I doubt if any of it ever reached those for whom it was intended: for as neither officers nor soldiers of the Malagasy army received any pay it was little wonder if none of the money ever reached the rank and file. I think some of the clothing and the medicines sent may have reached them; but of even that I am sceptical, such was the corruption that then prevailed. Reports reached us that some of the clothing was actually sold to the poor soldiers. The queen sent a large sum of money to the army on the north-west coast to be distributed among the soldiers; but the Hova officer in command appropriated the whole, and it was much the same with the quinine and other medicines sent for their use. Everything was sold to them by their rapacious heathen or semi-heathen officers.

During that year we had some very trying cases in which the severest church discipline had to be exercised, and a most unworthy pastor and an evangelist had to be excommunicated. The pastor had been put into office in the first instance simply because he was the eldest son of the chief of the village. An attempt was made to reinstate him, and for the same reason; but although the jury was packed, and to intimidate the 
people the chiefs from the neighbourhood had presented themselves, I had them and all the false members removed, the church doors locked, and the vote taken by ballot, and so these evil machinations were frustrated.

For some years there had been but a slight increase in the membership of the churches, either in the capital or the country; but there had been far fewer suspensions from fellowship than formerly, while the new members were of a more intelligent and satisfactory character. Up to the time of our second furlough in 1890 , this may be said to have been the case; but to have gauged the results of the work, either in the capital or in the country, by the handful of new members gathered in yearly, or by their seemingly slow growth in grace, would have been to make a great mistake. For after all, the true test of mission work is not so much the statistics of church members or adherents, or even the size of the congregations and schools; but the kind and character of the men and women those churches turn out, and how they stand the wear and tear of life, and face its temptations. Our church members were the salt that kept the whole mass from utter corruption; the only lights in a wilderness of darkness. Through them, and by means of them, religious influences and religious truth were penetrating and permeating all classes of the community. But just as you cannot diffuse influence over a whole countryside, and have the same visible results as you might, had it been confined to one village, or focused on a single congregation, so our work suffered from its very success, suffered in intensity and depth from its wide extension.

It also suffered somewhat from an overestimate of the past, and with the influences supposed to be at work. We are prone to compare the men of the present to their 
disadvantage with the men who lived, and worked, and even died for their faith in times of persecution in Madagascar and elsewhere. The estimate of the piety of these earlier times is contrasted with a piety which has not to face death, though it may have to face the more exacting tests of life and growth. In the view of these early and heroic witnesses for Christ, more has been expected of their countrymen than it was reasonable to expect at so early a stage in their religious history. Principle had to take the place of sentiment, and sincerity that of mere profession, before they could be called strong; but the power that makes for righteousness was at work among them, and had been from the first. Mysterious and indefinite in its operations, but obvious and mighty in its results.

The Malagasy are passing through their religious childhood, and have all the virtues and weaknesses of that stage. The Malagasy are a people who are still, as it were, but in the gristle, and not yet hardened into the bone of manhood. As a people they cannot originate anything, but they are great imitators, and they are also much readier to imitate the bad than the good. There is not much that is original in them, as a people, except ' original sin,' and of that virus they have a fair share. Overgrown children, they were attracted by what was sensational-especially in preaching-but not nearly so much by the tinsel in religion as might have been expected. This may account for the fact that neither the Roman Catholics nor their Anglican imitators have ever made great progress among them. They have learnt that 'all is not gold that glitters,' and are not in such danger as might have been feared of mistaking what Coleridge calls ' magpiety' for real piety.

With many of them the good fight of faith has been 
a terrible reality. They had to struggle with strong, fierce, animal natures, like men fighting with wild beasts. The courage and determination with which some faced the fight was simply heroic. They took their corrupt natures by the throat, and strangled them with the strength which God supplied. Others maintained the struggle half-heartedly, and in their own strength, and it failed them.

One man was suspended from church fellowship by one of the mother-churches in the capital. After some two years he applied to be readmitted, and as the pastor, deacons, and members were satisfied as to the sincerity of his repentance he was received back. As a thankoffering he gave the amount he calculated he would have given to the church during the time of his suspension, had he been in membership. After the church meeting he went up to the pastor and asked, in seeming astonishment, if that was all. The pastor said it was, and asked what else he expected. The penitent said, 'Are you not going to beat me?' 'Beat you ?' said the pastor. 'No, certainly not; we would never dream of doing anything of the kind.' 'Well, but,' added the man, 'I was a very prominent member of the church, and by my fall I greatly disgraced you all, and I feel that I so richly deserve a beating that I would be much happier if I got it.' 'It is not the custom of the church to receive penitents back into fellowship by thrashing them,' answered the pastor. 'You have been received back into membership, your thank-offering has been accepted, and you must go home feeling thankful and happy.' 'Yes,' said the man, 'but I would go home much happier, and with a quieter conscience, if I had had a good beating; for I feel I so richly deserve it, that the best thing I could get would be a good thrashing.' It was all that the pastor 
could do (and only after a long talk, and the most positive refusal to touch him) to get the man to go home without his coveted beating!

Our mission district of Anativolo, where we had fourteen preaching stations, with their small village schools, under the charge of three untrained evangelists, was utterly ruined during the year 1888 by a band of brigands from the forests of the north. They came as far south as within forty miles of the capital! At one village in the Vònizòngo district four men were killed, and thirty women and children carried off to be sold to the Sakalava tribe on the west coast. It was five years before we got these mission stations in Anativolo restored; then the march of the French expedition from the north-west coast, and after that the rising against the French rule, ruined the work for another three years, and the district is now so sparsely populated that I fear it will never again be what it was.

We left the capital in April, x888, for the small London Missionary Society sanatorium on the hills at Ambàtovòry for our annual month's holiday. I had seldom looked forward with more longing to our month of rest, expected more from it or received less. On the night of Wednesday, May 9 (the night of the large local weekly market for the neighbourhood), I was sitting reading in our small parlour. About ten o'clock my attention was attracted by a slight scratching at the Venetian shutter-door of the French window, which opened on to the walk. I looked up from my book, and thought that the cat had been shut out. I turned again to my book. I had hardly done so, however, when with a crash the Venetian shutter-door was torn open, the French window burst in, and a band of burglars sprang into the room, and I saw the gleam of their long Malagasy knives and meat-axes! So utterly 


\section{A Visit of Burglars}

unexpected was the thing that I was stupefied for a few seconds. I scarcely realized what had happened. As I had been sitting opposite the open door of the room I sprang through it, closing it behind me, to which act I may have owed my life, although I hardly think they would have harmed me, unless I had offered resistance. I rushed upstairs to the bedroom, where I found my wife in a state of terror; she had been startled from sleep by the crash. She thought the house had been struck by lightning. I had taken my small bull-dog revolver with me for mad dogs, with which we were rather bothered in those days ( $\mathrm{I}$ had shot five of them in our own yard during our first term, and one in our own kitchen), and now I went to get it in case it might be needed. Unfortunately it had been hanging in the lobby, and passing it in my hurry, by the time I had discovered my mistake the burglars had secured it. It would have been of no use to me, however, even if it had been in the bedroom, as the only three cartridges I had brought with me were in my courier-bag, which was hanging on the back of the door of the room into which the burglars burst. As there was no weapon of any kind in the bedroom, not even a stick, we could do nothing except remain quiet-a very difficult thing for me to do while the house was being ransacked-and commend ourselves to the care of God. After recovering from the shock and fright of my first surprise, I wanted to go out and attack the burglars with anything I could find; but my wife and our good old nurse, Rafàra, held me back. The former said if I went out of the room, and they caught sight of me, they might fling a knife at me, which might cost me my life.

The band was a notorious one, and had been the terror of that countryside for years. The leader had been often 
in prison, and his character was well known; but he had always escaped being put in chains or being sent to penal servitude, doubtless by bribing the judges. His assistant was the son of the so-called superintendent of police for the district, who informed his father that if he gave any information that would lead to his capture he would do for him! The majority of the band were most desperate fellows, on whose breasts had been made seven times the scars of the blood brotherhood, which pledged them not to turn queen's evidence if it cost them their lives. There were two lads among them from whom much better things might have been expected, and one of them was reported to have provided the knives for the night's work! As treasurer of the missionary fund of the 'Union' I had had $£$ roo handed over to me, just before leaving the capital, and it was probable the burglars had heard of that, and believed I had taken the money with me. Twenty of the band were caught, and sixteen sent in chains to the Malagasy Botany Bay ; but none of the property stolen was ever recovered, only its value was refunded by the authorities from the sale of the property belonging to the burglars.

Hugh Miller says: 'There are two periods that are favourable to observation, an early and a late one. A fresh eye detects external traits and peculiarities among a people, seen for the first time, which disappear as they become familiar; but it is not until after repeated opportunities of study and a prolonged acquaintance that the internal characteristics of a people begin to be rightly understood.' This is especially true with regard to Madagascar and the Malagasy; for while there was, and is, much about them and the history of Christianity in the island, as also about their present and future, to deeply interest and indeed fascinate any one who has 



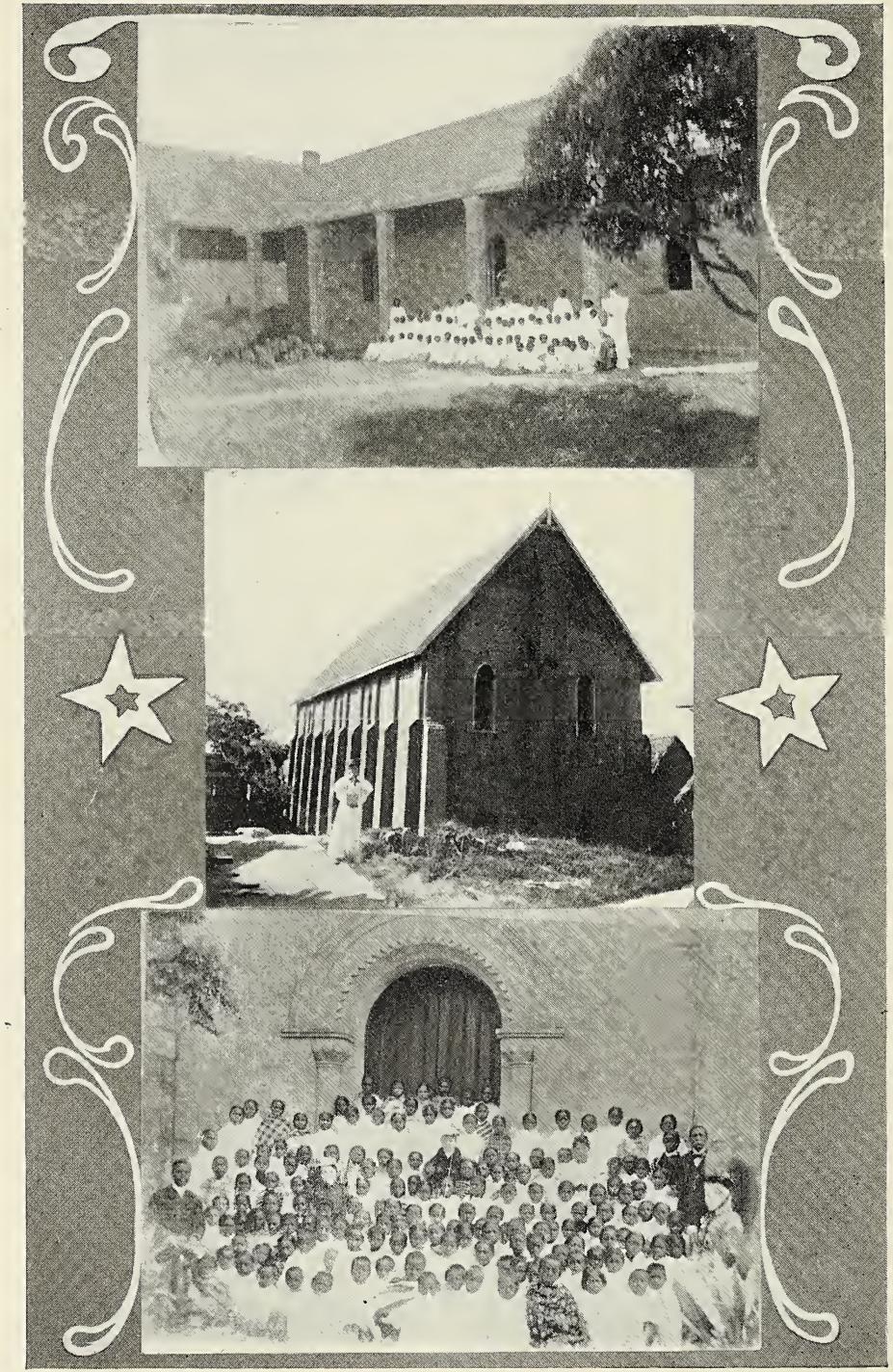

THE OLD SCHOOL, AMBATONAKANGA.

THE NEW SCHOOL, AMBATONAKANGA.

GROUP OF SCHOLARS, TEACHERS, AND CHRISTIAN WORKERS. 


\section{New Temptations}

a spark of missionary enthusiasm in him, still it is only to those who have had repeated opportunities of studying the people, and a prolonged acquaintance with them, and the work in all its phases, that the internal characteristics of the people, and real conditions of the work, can be rightly known. As it was in our Lord's time, and is at home now, the rich do not crowd into the Kingdom, and it is left chiefly to the common people to hear the Gospel gladly, and press into it ; so, with few exceptions, it has been in Madagascar. The higher the social scale the more profuse was the profession, the less the real practice. From many points of view both the capital and the country districts might have been compared to a stagnant pond, on which the green slime of ages had gathered thickly. When the living waters of the Gospel flowed into the pond a commotion was caused, bad odours were generated, and much was brought to the surface that had long been hidden by the slime or embedded in the mud. The only hope of clearing away the filth was to keep the living waters streaming into the pool. Purification in such a case could not be the work of a day; the filth was the accumulation of ages. Twenty years could not do much.

We found even in our last year, before taking our second furlough, that the mother-church and congregation of A-kànga was far from being a pure one. Our first troubles that year began with a controversy with regard to Christians-especially pastors, preachers, and Sabbath-school teachers-countenancing theatres, operas, and balls. The poison of so-called civilization, frivolity, and indecorum had been introduced, and was affecting certain sections of the community. Those of us who had the courage of our convictions with regard to such primrose paths and gilded roads to ruin felt it 


\section{0}

\section{The Light Extending}

to be our duty to set our faces like flint against them, and denounce them both in public and in private. As a result we had the honour of being for a time the bestabused men in the capital. We were held up to ridicule as bigots, and charged in the public press with being enemies to the public weal. We were hindering Madagascar in her march towards civilization. The line of demarcation, however, between the precious and the vile, between those who feared the Lord and those who feared Him not, became more distinct at this time than it had been since the ' killing times.' The sifting process had, in a measure, begun; not in the way we would have chosen, but perhaps in the way that most clearly showed who really had in them the root of the matter, and preferred the house of God to any of the synagogues of Satan.

The war between France and Madagascar ended with the conclusion of a treaty of peace in 1886; but the war between real religion and French civilization was greatly intensified. By the treaty concluded, while the Hovas had the control of all domestic affairs, France obtained a privileged position with regard to foreign affairs. A French resident was established at the capital with a guard of honour of fifty French soldiers. It need scarcely be said that, in such circumstances, there was friction from the first between the French and the Hova governments-perhaps it was intended there should beand things went from bad to worse, until what had been wanted all along was obtained, a pretext for sending an expedition to take over the island. And yet it will never be worth a tithe of what it has cost, and what it is likely to cost, in men and money. The French government was grossly deceived about the policy and work of the London Missionary Society, and the real 


\section{A Strange Mixture}

state of affairs-perhaps they were not anxious to know the truth! - by the Jesuits, the colonial party, impecunious Frenchmen, French-Creoles, and others who had their own ends to serve in urging the government of the day to take action.

The Malagasy, once you really know them, are most likeable; but you have to know them thoroughly. The Hovas have in them the making of a fine people, and in proper hands much might be made of them; but nothing will be made of them if they are simply regarded as dirty niggers or 'imitative monkeys whose market value is nil.' They are a most extraordinary mixture of love of money, simply for its own sake, and wondrous generosity; of suspicious cunning, and unqualified trust in those whom they respect and love; of childlike and docile simplicity, and the most mulish and unreasoning obstinacy. I believe it was this last trait in their character sanctified which enabled them to endure martyrdom so calmly and courageously. If once you win their respect and love-and they are not difficult to win-you may do almost anything you like with them, and they in turn will do anything for you. Doubtless some of the above-named features are common to most heathen people; others are peculiar to the Malagasy.

It does not follow nowadays that when any great man in either the political or religious world changes his views, or his creed, all his followers or dependants change with him. Each one claims the right now to judge for him- or herself; but, as we all know, it was not always so. There was a time in the history of our own and other lands when clans and even countries did not dare to differ from their chiefs or sovereigns. If the sovereign or chief professed conversion, it almost always followed that the whole kingdom or clan did 
the same. History repeated itself in this respect in Madagascar. When the Hova queen made profession of Christianity the vast majority of her subjects in the central provinces imitated the royal example. The natural result followed. These wholesale conversions were found to be of a very superficial character, as we find in the early history of the church nearer home. Districts once nominally Christian relapsed into heathenism, and had to be reconverted; so it was in some cases in Madagascar. There was not so much danger of the Malagasy relapsing into absolute heathenism; but there was a great danger of their resting in a form of godliness, while denying its power.

It was difficult to get two truths burned into their minds: the heinousness of sin-whether found out or not-and the holiness of God. If they did not quite believe that ' 'tis only daylight that makes sin,' they certainly did believe that ' a sin concealed is half-forgiven.' It is only fair to remember in view of this the dense ignorance of the vast majority, and the fact that they had so lately emerged from heathenism. They were strange blendings of good and evil; of vices and virtues; of lofty aspirations and gross pagan practices; of Christian ideals and heathen traditions. Still, notwithstanding these grave drawbacks, there was much to be profoundly thankful for, and especially the help we received from our converts. We had a noble band of native fellow-labourers-pastors, local preachers, teachers, evangelists, and latterly Sabbath-school teachers. What was most needed was more evangelical fervour, moral earnestness, and missionary enthusiasm. 'No kind of mission work,' some one has said, 'is safe that is not enthusiastic.' We are still, I fear, far from being safe in this respect, either at home or abroad. 


\section{Cold and Corruption}

Emerson speaks of liberty and snow always being associated; but in religious affairs cold and corruption, torpor and formality generally go together. We are told that fevers never spread except in hot weather; cold always kills the infection. That may be quite true with regard to fevers and infection; but we know as a fact that real religion seldom spreads except in an atmosphere of fervour. Frigid religion will never help to kindle the fires of a new devotion in hearts dead in trespasses and sins; it can only help to foster formality. Cold may prevent the spread of infection in the natural world; but it is almost always the cause of disease, death, and corruption in the spiritual. Frosty friendships are but sorry affairs ; but frozen religion is one of the abominations that make desolate. I know that fire may be got by using a piece of ice as a burning-glass; but ice is not generally used for that purpose!

By the death at this time of Ràsamoèly (a young dentist, and one of our local preachers at Lazaina) in the out-district, we lost one of the best and most warmhearted of our young men, and that too under most painful circumstances. There had been a number of very daring burglaries in the capital and suburbs during the previous few months. A few nights before Christmas, 1889 , Ràsamoèly dreamt that his house had been broken into by burglars, and starting up in his fright and half-asleep he jumped out at the window. $\mathrm{He}$ fell on his back, and died a fortnight after from spinal injury.

Strange to say, although the accident had happened in the capital, I had not heard of it until the morning of his death, when he sent for me. I went to him at once, and found him lying on a small truckle-bed, very earnestly engaged in prayer. He was praying with his 


\section{4 \\ The Light Extending}

eyes open, and saw me enter the room and take a seat at his bedside; but went on praying fervently and beautifully for some time after I entered. When he had finished we shook hands, and he thanked me for coming so promptly to see him. He then began to tell me very quietly and calmly that he was dying, that the doctors had told him there was no hope; but he added: 'I am not afraid to die; for I am trusting in Jesus Christ for salvation.' His mother was sitting by his bedside, quite broken-hearted, weeping and sobbing in a most passionate way. He talked to her so gently, telling her that she ought not to grieve so sadly because he was dying. 'If,' he said, 'I were in chains, or in prison as a burglar, or were dying from the effects of bad living, then you might weep, but not because I am going home to my Father's house on high. I am very sorry to be separated from you so soon, but we shall soon meet again to part no more.' He also talked most solemnly and earnestly to his brother and sister, and made them promise that they would give their hearts to God and live for Him.

$\mathrm{He}$ and I had a long talk together, after which I prayed with him. My wife and I called in the afternoon to see him. We found him still conscious; he recognized us both, shook hands with us, and then asked me to pray again with him. Death was now rapidly approaching, and just after I had finished praying, he complained of the cold creeping up his body, and asked for more blankets. His attention then seemed to be suddenly arrested by something he saw in the roof of the room. He gazed with seemingly rapturous astonishment, while a look of ecstasy passed over his face. Had he a vision, and of whom, or of what? Did he see his father, the good old deacon, or did he see the Saviour Himself waiting to welcome him? He looked several times 


\section{Practical Christianity}

intently at us, as if he would have said: 'Don't you also see this?' but he seemed no longer able to articulate, and in a short time all was over. He was safe home, and with the Saviour Who had loved him and given Himself for him, and on Whom I had heard him so fervently call that morning for help and strength. His was the most triumphant death I had ever seen.

We were frequently cheered by hearing of instances of the truth taught being translated by our people into rules of life and conduct. A teacher of one of our village schools, on his way home from the capital one day, found a large sum of money lying on the grassy pathway by the roadside, rolled up in a small piece of dirty calico. He knew at once that some one had lost the money, but as there was no one within sight, he had no idea to whom it belonged. He went on his way for a few miles, when he came upon two men excitedly talking about something.

As he drew near them, and caught something of their conversation, he asked them if they had lost anything; and they answered that they had lost a large sum of money, but where they could not tell. They were returning from a local market, where they had sold an $\mathrm{ox}$, and it was the price of the ox they had lost. One of them had rolled the money in a piece of calico, after the usual Malagasy fashion, and stuck it in his girdle, from which probably it had slipped out when he was sitting on the grass by the roadside resting. The teacher handed them the money he had found, and asked them if that was their money. On seeing and counting it they said it was, and asked him where he had found it, and how he knew it was theirs. He told them how he had found it, and that he had gathered from what he had heard of their conversation that they were the owners 
of it. They asked him if any one saw him find the money, to which he answered, 'No.' How did he know then that it was theirs? they asked. He answered he did not know; how could he? he only suspected they were the owners from what he had overheard of their discussion. Then they asked how it was that he came to give up the money, seeing that no one saw him find it, and neither they nor any one else would ever have known he had it. The teacher said: 'You are quite wrong there; for, in the first place, it would have been dishonest of me to have kept the money, and in the second place, God saw me find it. He would have known.' One of the men asked him: "Are you a "prayer"?' To which he answered: 'Yes.' 'Then,' he said, 'let me shake hands with you, and ask your forgiveness. Ever since the "praying" was introduced into the island, I have been an enemy to it, and done everything in my power to oppose it, for I thought it wrong to forsake the religion of our forefathers and take up with the white man's; but I shall do so no more. I shall do all I can for the future to help the "prayers," and I will learn to pray myself. A religion that can lead a young man like you to return such a large sum of money, when you might have safely kept it, and neither we nor any one else would have ever known-that religion must be the true one, and a good thing for the country and the people.'

On August 5, 1890, the British government concluded a treaty with France in which, very unjustly as most people think-because he was giving away what did not belong to England, and granting what he had no right to grant-Lord Salisbury recognized a French protectorate over Madagascar. The French government consented to the following clause, which most of us knew was hardly worth the paper it was written on:-' In Madagascar the 


\section{Dews of the Spirit}

missionaries of both countries shall enjoy complete protection. Religious toleration and liberty for all forms of worship shall be guaranteed.' Immediately on the seizure of the island, that clause practically became a dead letter, as the Jesuits were let loose and allowed to work their own will for a time, until they overreached themselves, and had to be first checked and then repudiated.

During $189 \mathrm{r}$ there was a slight religious movement in the capital. There were not 'showers of blessing,' but the dew of the Spirit descended, and the churches were quickened and refreshed. Perhaps more was made of it than should have been; but this was not much to be wondered at, seeing it was the first experience of the kind in the capital. There was a good deal of blossom, but not much fruit came of it, only what did come was genuine. Some of the best, most satisfactory, and most devoted of the younger Christian workers in the capital and neighbourhood to-day are among those who found their way into the Kingdom then. One lad was converted through reading a story in English, in a volume of the Herald of Mercy, which I had given to a friend of his, from whom he borrowed it. He went to the secretary of the Imèrina district committee, and confessed to having stolen two shillings from the normal school money, some years before, when I was in charge of the institution. He was a scholar there then. He pleaded for forgiveness, and returned the money fourfold! The secretary told him how glad he was to hear of his conversion, and to see the fruit of it in his confession and restitution.

Political difficulties began to arise, and a spirit of unrest spread among the people during 1893. The prime minister, deceived by those whose interests it served, was led to believe that his son and son-in-law had 
conspired against his life. They were tried and sentenced to death, but the French resident and others remonstrated so strongly against such a course, that the sentence was reduced to banishment for life. All these things affected the work, but still the consolidation of the best of the country churches, and the work in the village schools, made most satisfactory progress.

From the time of our settlement in the capital, I had felt that not nearly enough was being done for the girls and young women of Antanànarìvo, and that there was more than room for another high school for them in the neighbourhood of A-kànga; I had tried hard to persuade the Imèrina district committee to take the same view. The majority of the committee was with me, but such was the opposition from vested interests that the proposal had to be given up. While at home on furlough I had received help from friends for our work, and so on my return I built a small school in the A-kànga churchyard, and began, in a very humble way, a private high school for girls. We and our friends found eighty per cent. of the funds for the school for the first five years. We provided all the material for the sewing-classes there, and at the centres for the village schools, while our eldest daughter devoted herself, as a labour of love, for three years as it proved, to the work of the school. With much covert opposition, condemnation, and with very faint echoes of praise, or encouragement, in the end she made it what it became. The following sketch, written some years later, shows how this work prospered. It was written by Miss Matthews, who for some years superintended the work:-

'Almost from the time of my father's settlement in Antanànarivo, in 1882 , he had the idea that enough was not being done for the girls and young women of 


\section{A New Move}

Antanànarivo, while so much was being done for the boys and the young men. He did not think that two high schools-the London Missionary Society Girls' Central School and the Friends' Girls' High Schoolwere enough for the girls and young women of a city of nearly a hundred thousand inhabitants. The London Missionary Society's Central School supplied the wants of the centre of the capital, while the Friends' supplied the needs of the north end of the capital; but there was really no proper provision for the needs of the south end of the capital, or for the west, south-west, and northwest sides of it.

'When my father was at home on furlough in 1890 some kind friends gave him money to help him with his work, and with that, and a grant of fifty pounds which the directors made him for the purpose, on his return to Madagascar, in 1892 , he built a schoolroom in the Ambàtonakànga yard. He soon saw that it would never be what he wished it to be without a European lady in charge of it. In 1894, as the time drew near for my mother's return to Madagascar, it was arranged that I should return with her to assist her with her sewing-classes.

'By the time we arrived at Madagascar father had conceived the idea of my taking charge of the girls' school at Ambàtonakànga, and a few days after we arrived he took me to see it, and said, "There, my dear; there is a school for you to take charge of, and to work up."

"I was rather astonished, and said, "But I am not a teacher; I have had no training as a teacher." Father said, "Neither am I; just buckle to and do your best"; so that is what I did!

'There were twenty-six pupils when I took charge 
first, and we had two hundred and thirty when we left. Shortly after I took charge we had to leave for the coast owing to the French war, and the march of the French on the capital; and we were away three months. For nearly four years I superintended the school as a labour of love, taking up the work as something providentially laid upon me. I was splendidly assisted by my staff of Malagasy teachers, but most of all by E. Rabarijaona, the principal teacher, really the head master of the school, to whose untiring efforts we owe it, in the main, that the school has been for so long in such a satisfactory state. After the visit of the deputation, the foreign secretary and Alderman Evan Spicer, on their recommendation the Directors recognized my work in the school.' 



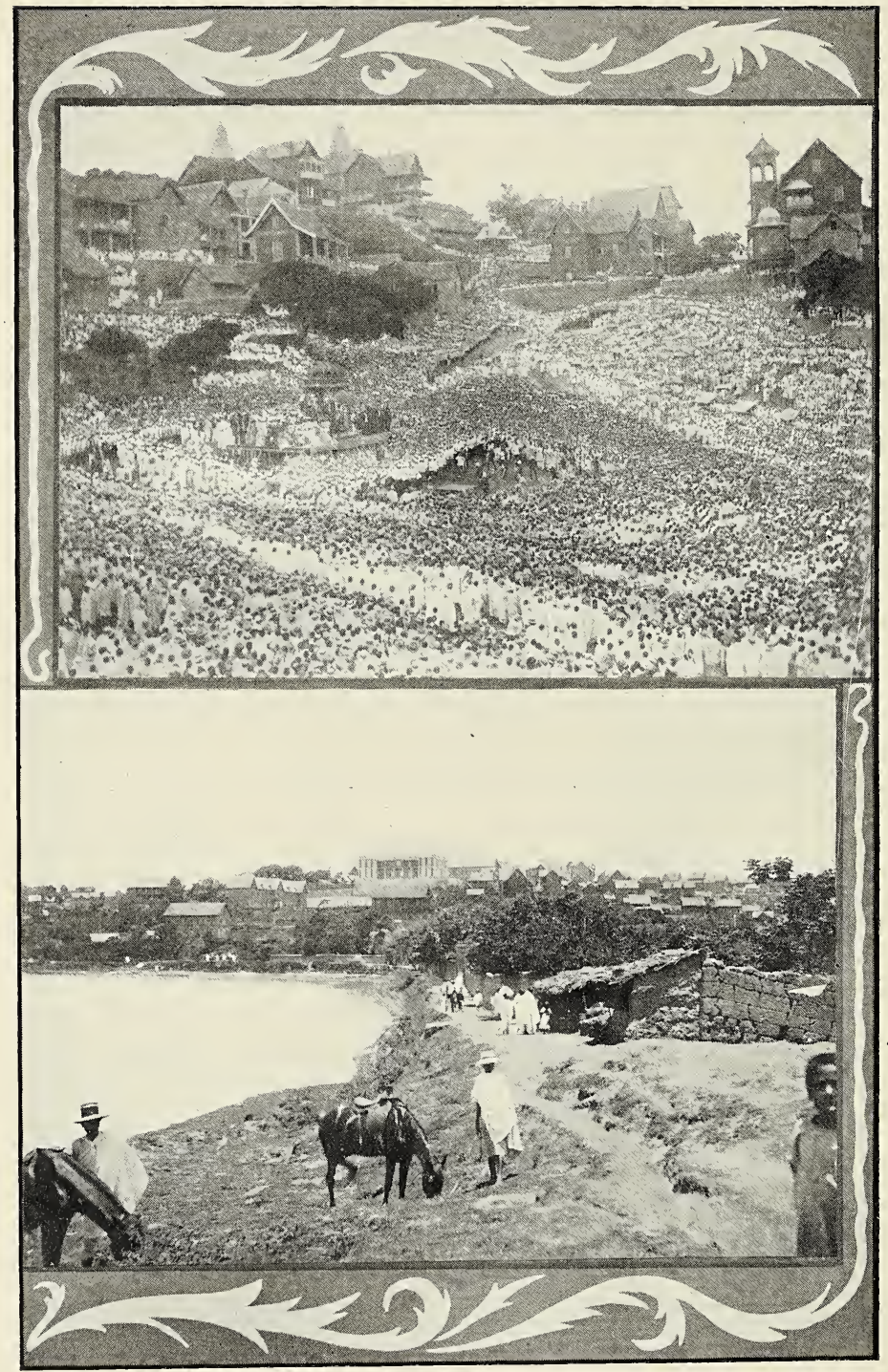

THE LAST KABARY.

THE QUEEN'S LAKE, ANTANANARIVO. 


\section{CHAPTER XV \\ THE CONQUEST OF MADAGASCAR}

' The dark places of the earth are full of the habitations of violence.'- PSALM lxxiv. 20.

THE following extracts from the Ten Years' Reviez of the Madagascar Mission, I891-1900, published by the London Missionary Society, will show the steps which led up to the conquest of the island by France.

'A treaty concluded at Tàmatàve, on December I7, 1885, after the desultory Franco-Malagasy hostilities, which had continued at intervals for three years and a half, conceded certain rights and privileges to the government of the French Republic which no other foreign power enjoyed. Difficulties and disputes arose from time to time, however, on various points directly bearing on the treaty, and notably on the two following: the validity of the appendix which was added to the agreement, and the rights of the native government to issue exequaturs to the foreign consuls. As time wore on the tension between the two parties became more and more strained, until at last the French government, feeling the situation to be intolerable, determined to make one final and serious effort to bring the Malagasy government to submission by peaceful means, and, with this end in view, sent out in October, r894, a plenipotentiary in the person of M. Le Myre de Vilers, who, a short time previously, had been resident-general of 
the island. But, as the queen and prime minister were unwilling to yield to his demands, his mission proved abortive, and he returned to France. The French government decided, therefore, to settle the matter once for all by force of arms.

- An expeditionary force, under the command of General Duchesne, with General de Torcy as chief of the staff, and consisting of 658 officers and 14,773 men, with about 6,000 auxiliary conductors and baggage-bearers, 641 horses, 6,630 mules, 5,040 Lefebvre carts, and 46 pieces of artillery, was dispatched in the early part of r895 to compel submission to the French demands. Besides this military force, a naval division of nine or ten vessels operated on the coast, and kept the inhabitants in continual alarm by the occasional firing of shells. A considerable proportion of the troops consisted of Algerians, Dahomeyans, and Senegalese.

'The first detachment of soldiers, under General Metzinger, was landed at Mojangà, the chief port on the north-west coast, which was to form the base of operations. General Duchesne arrived there on May 6, and by the 18 th, preliminary skirmishes having already taken place in the neighbourhood, everything was in readiness for an advance. The difficulties to be encountered proved greater than had been anticipated. Arrangements had been made for transporting the forces from Mojangà to Mèvatanàna (about two-fifths of the distance to the capital) by way of the river Bètsibòka. But this was found, for one reason or another, to be, to a large extent, impracticable. Attention was turned, therefore, to the task of widening the native path running alongside the river, so as to allow the transport of the baggage and ammunition by means of Lefebvre wagons. It was chiefly during these operations, carried on in 
a hot and fever-stricken territory, that the French lost so many lives from disease.

'Having established himself firmly at Màngasoàvina, General Duchesne, knowing that the rainy season was approaching, determined to desist from the attempt to continue the new road, the construction of which had occupied so much time, and had cost so much labour and sacrifice of life, and decided to take forward a flying column to seize Antanànarivo. He had learned from experience that, in spite of the vastly superior numbers of the Malagasy soldiers, little was to be feared from any opposition on their part-retreat from one position to another, after firing a few random shots, being mostly the order of the day. We might say much on the disorganized condition of the native army, the feeble resistance offered by it, and the general corruption prevailing at head quarters at the time. Certain it is that the Malagasy had but little idea of the military strength and skill of their opponents. The flying column consisted of 237 officers, $4, \mathrm{Or}_{3} \mathrm{men}, \mathrm{I}, 5^{\mathrm{I}} 5$ conductors, with nearly 3,000 mules. The commissariat was provided with rations for twenty-two days. The Hovas were driven from point to point, and, after a forced march of sixteen days, the French troops found themselves encamped a little to the east of Antanànarivo. Only those who were here at the time can adequately imagine the excitement of the people, which had been growing day by day, as it became increasingly evident that the French troops were not to be resisted in their onward progress; and now that they were at their very doors, their excitement was at blood-heat. The capital was crowded with soldiers, who were stationed in various parts of the town; but it was evident from their condition that little could be expected from them. We feared, and 
we had feared all along, that the government might lose its control of the people, and that the country might become a prey to riotous and murderous mobs; and it says a great deal for the authorities that they were able to keep well in hand the reins of power during the whole time when feeling ran so high. Even when the French were close at hand, and when the town was filled with thousands of people armed with guns, spears, swords, large knives, or cudgels, perfect order was preserved, and, so far as we remember, not the slightest sign was manifested, outwardly at least, of any hostile feeling towards the foreigners who had chosen to remain.

'The night before the town was taken was as peaceful as usual. The thought of the coming noise of battle and the threatening horrors of the morrow doubtless increased the sense of calm that prevailed. By six o'clock in the morning of September 30 all was astir in the French camp, and the Hova soldiers were ranging themselves for defence on the various small hills about half a mile east of the capital, which run north and south parallel to the ridge on which the city is built. About eight or nine o'clock the French troops were seen descending the hills three or four miles to the east into the valley which separated them from the bulk of the Hova forces, where they could no longer be seen from the capital. Fighting had by this time commenced in earnest. Repeated volleys, directed against the Hovas on the hills, were heard from the valley below, and many stray bullets fell into the town. Although the Hova soldiers did, to some extent, redeem their character in this their final struggle, and though their artillery more especially was served at one or two points with considerable skill and bravery, still it was evident that the forces were neither properly led nor efficiently organized. 
A little after eleven o'clock the French, having shelled the positions occupied by the Hova artillery and silenced their guns, began to appear here and there on the range of hills occupied by the Hovas, who very soon, therefore, retreated from their positions. Near the Roman Catholic Observatory, situated on one of the hills, several houses were in flames, whilst a Hova battery, placed near the palace, opened fire on the French who had gained the summit. The fighting now had almost ceased, and there was a period of quiet. In the meantime, however, the French were bringing their field-pieces into position. Soon the bombardment of the town commenced, but it was evident that the French were anxious to avoid committing any unnecessary damage. Their fire was only kept up at intervals, and was concentrated on the Hova batteries and the palace. One of the melinite shells, falling in the palace-yard, where many thousands of people, chiefly soldiers, were assembled, destroyed many lives. This brought matters to a crisis. At about three o'clock the Malagasy flag was hauled down from the top of the palace, after which not another shot was fired. Half an hour afterwards some native officers were seen carrying out a white flag to the French lines, submission was rendered, and the war was at an end.

'The expedition, which had been conducted throughout by General Duchesne in the most humane and merciful manner, had cost the French nation $£ 2,600,000$, and, what was more, the lives, almost entirely from disease, of $5,75^{6}$ officers and men.

'Within an hour after the submission, many of the French troops, weary and footsore, entered Antanànarìvo, glad doubtless to get to the end of their long and exhausting march. At the gate of the hospital immediately to the east of the town a sad spectacle was witnessed- 


\section{The Conquest of Madagascar}

a long line of mules bringing in the sick and wounded, some of whom were moaning in agony from the pain of their diseases or their wounds. Next morning at eight o'clock General Duchesne and his staff, with the remainder of the troops, entered the town. A treaty of peace, in which Madagascar was distinctly and definitely placed under the protection of France, was signed at three o'clock in the afternoon, and on the same day was ratified by the queen. After this ratification, the general told the queen that she might again raise the Malagasy flag above the royal palace. Six days after the signing of the treaty General Duchesne received a copy of another agreement from his government of a still more rigorous character, the presentation for signature of which, however, he left to his successor, M. Laroche.'

I had to go to the coast in 1894 to meet my wife and daughter, who joined me that year. A short time after their arrival, M. Le Myre de Vilers brought the French ultimatum, which it was impossible for the Malagasy to accept. This was just what was wanted by some, and the French flag was hauled down and friendly relations broken off.

Most of the European ladies left the island, and I took my wife and daughter to the east coast for fourteen weeks, during the march of the expedition on the capital. The queen had been shamefully deceived, the people betrayed, and the fatherland sold by a party of traitors in the palace, who had been seduced from their allegiance by a protégé of the Jesuits, who had been in the pay of the French for years. The traitors posed as ultra-patriots, and thus thoroughly deceived the queen. They persuaded her to discharge all the European officers in the service of the government, while the services of others, who were willing to help 
the Malagasy to defend their fatherland were declined. She acted like a mad woman-refusing to follow the advice of the prime minister, and following the advice of these traitors, as also that of her incapable relatives, and her nurse! The traitors told her they were not to depend on foreigners for the defence of their fatherland. They were quite able to drive the French back to the sea. The queen did not get her eyes opened, nor find out how grossly she had been deceived, until the French army marched over the hills on Antanànarivo-and then it was too late.

It was thought in England, and elsewhere, that the Malagasy made a most disgraceful appearance in the defence of their fatherland; but it was not known that the right sort of people were kept from rising to defend their country by these traitors. Nor was it known that neither officers nor soldiers of the native army received any pay, and the officers lived by blackmailing their men. Of 20,000 sent out to meet the French, some 14,000 bought themselves off or deserted. The chief traitor had control of the Madagascar Times, in which the French were vilified, and represented every week as defeated and all but annihilated.

All this was a blind. This patriot volunteered at the last to lead 6,00o men to meet the French; but took the precaution of going along a route by which he knew they would not come. If the French officers had had their way, these traitors as a body, and the chief one in particular, would have had short shrift; and if they had been so dealt with, the lives of many honest and innocent men would have been saved, and many mistakes avoided. It was reported that copies of the prime minister's dispatches-as commander-in-chief of the Malagasy army-were sent to the French general, 
and thus he knew every move that was to be taken, and was prepared for it.

After the French reached the capital, and the people saw how basely they had been betrayed, they rose roo,ooo strong, and if they had had arms and ammunition, or could have obtained them, the French would have been defeated before reinforcements could have arrived. This rising may have been sheer madness on the part of the natives, after things had gone so far; but they did not know this, and they were greatly exasperated over their betrayal. As the old heathen and semi-heathen element greatly preponderated in the rising, and all who would not join it were shot or had their throats cut, thousands who saw the madness of the rising were compelled to join it, or at least to pretend to join. They suffered severely for their unhappy effort to redeem the situation, as also did their relatives-many being shot as suspects.

The French expedition landed at Mojangà, on the north-west coast, in April; but it was October I before it entered the capital. It had been detained-so a French officer afterwards informed me-for six weeks near Mèvatanàna by a cablegram from Paris, instructing the General that he was not to enter Antanànarivo before October $\mathrm{I}$, in order that the news of its fall might reach Paris by October ro, and so cause a sensation at the opening of the Chambers. The detention of the expedition among the swamps and fever fens of that part of the island cost the lives of hundreds of the poor French soldiers; but, as the above-mentioned French officer said, what did Paris politicians care for the lives of the poor French soldiers! The poor fellows had been set to the mad task of making a road from Mojangà to Antanànarivo-some 400 miles-for the famous, or 


\section{The White Flag}

infamous, Lefebvre carts. To set these young fellows, fresh from the fair fields of France, to make a road through such a malarial country as North-West Madagascar, under a tropical sun, was nothing short of murder. The General had to attempt to carry out his instructions, and bravely tried to do so, until it proved impossible. The lives of some 6,00o French soldiers were sacrificed to the mad attempt, after which, of course, the brave General who had done his best had the blame thrown on him for their murder instead of on the man who had issued the order for the making of the road.

A rush was made on Antanànarivo with a flying column, and the capital was captured on the afternoon of September 3o. This event caused great excitement in France-the people went into ecstasies over it. In reality nothing could have been easier. The General knew there would be no serious opposition; the traitors had arranged matters beforehand. The Malagasy troops, who ought to have been there to defend the capital, had been carefully removed, and taken away to meet the French along a route by which it was well known they would not come. There was slight skirmishing all day, but no serious fighting, and by two o'clock the French were in possession of the heights round Antanànarivo, and the city was at the mercy of their guns. It had been decided, it seems, that if the Malagasy flag on the great palace was not lowered by half-past three fire was to be opened on it, with melinite shells. This would have laid the capital and neighbourhood in ruins, and might have sacrificed thousands of lives, as there were ro,000 barrels of gunpowder stored in the great palace!

About three o'clock of the day on which Antanànarivo fell, a shell was thrown into the palace-yard, which was then packed with people, who had taken refuge there. 
By this shell some sixty were torn to pieces under the eyes of the queen, who with the prime minister was on the verandah of the great palace. Her Majesty all but fainted at the sight, and at once gave orders for the flag on the palace to be lowered. Her eyes had been opened by that time, and she saw how basely she had been betrayed by those whom she had trusted. No one would obey her and lower the flag until, at last, one of the menials of the court climbed up, and cut the rope. An officer-the protégé of the Jesuits and seducer of the other traitors from their allegiance, and their coach in the part they were to play-and one of the queen's private secretaries were sent out with the white flag of surrender. They were only just in time, as it was 3.20 when the flag was seen, and the bugles sounded cease firing. Another ten minutes, and the bombardment with melinite shells would have commenced. The guns were loaded with them, the officers standing by, watch in hand; but in the providence of God the appearance of the white flag averted the catastrophe.

After the French had established themselves in the capital, Rainilaiàrivòny, the late prime minister, and husband of the queen, was deposed. He was then a man of nearly seventy years of age, and for many years had been the one prominent figure in the island. His character was a strange mixture, and, living as he did through the period of transition from heathenism to Christianity, he seemed more or less to partake of both elements, the latter, however, predominating. For, whatever may have been his faults, he was, not only in natural ability, but in general uprightness, head and shoulders above most of those by whom he was surrounded. He was the genius of the Hova people-one of the ablest men I ever met. He lived a thoroughly respectable, 


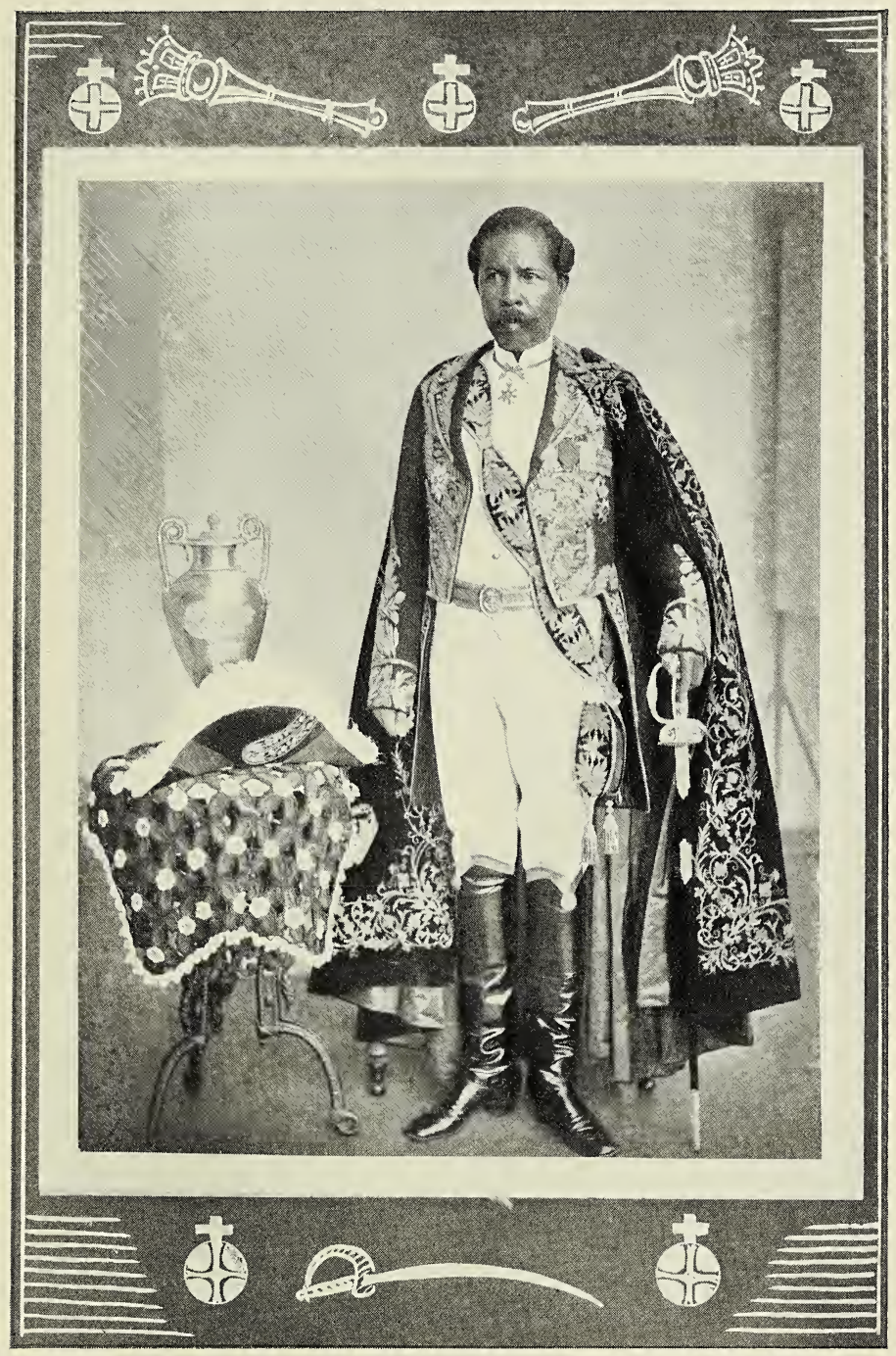

RAINILAIARIVONY, THE LAST PRIME MINISTER OF MADAGASCAR. 

upright life; introduced, especially in earlier years, numerous beneficial reforms; was in entire sympathy with all educational and religious work; and had ruled the island for thirty years as it never had been ruled before. He was then nearing his dotage, and the French removed him. He was taken to one of his country seats a few miles to the north of the capital, where, after suffering imprisonment for some months, he was, soon after the rising began, banished to Algeria, and died there about five or six months after. His corpse was taken back to Antanànarìvo some five years after, and buried in the family tomb.

General Duchesne, who was a chivalrous French gentleman of the old school, treated the queen with the utmost courtesy and kindness, and did all in his power to soften her fall. Very different indeed was his treatment of her from that which she afterwards received. For his chivalry he was attacked and abused by a section of the French press. The queen had been betrayed (a word which Frenchmen are themselves prone enough to use with less justification) rather than conquered. All this was forgotten by those who profited by her fall. Sympathy was denied her because she was only a nigger! The General, however, stuck to his guns, declined to do anything dishonourable or degrading, and behaved all through in a way that earned for him the respect of all those-natives and foreigners-whose respect was worth having. It was due to him, who had throughout shown himself to be not only a kindly disposed and merciful man, but also a rigid military disciplinarian, that there was no looting, no drunkenness, no disturbance of any kind, and that all provisions were bought-in the capital at least-with honest cash.

On the march of the expedition through our old 
district of Vònizòngo, some of the French black troops took Rainihàrisòa, a Malagasy medical practitioner-an old pupil of mine-prisoner, and robbed him of his watch. He was brought before General Duchesne, who asked how he had been treated, and if he had been robbed of anything. He told him of his being robbed of his watch. The General asked the value of it ; was told $£_{3}$. He immediately handed that sum to Rainihàrisòa. He then summoned the captain of the black troops who had committed the robbery before him, and in the sternest terms informed him what would be the consequences if such conduct was allowed to be repeated. Notwithstanding all that, the wire-pullers managed to have him nominally honoured, but practically disgraced and shelved. The blame of all the blundering and sacrificing of soldiers' lives during the campaign was laid upon him, and not on the real culprit at the War Office.

Immediately after the arrival of the French at the capital William and Lucy Johnson of the Friends' Mission, with their little daughter 'Blossom,' were murdered at Arivonimàmo, in the west, by a semi-heathen mob. The Johnsons ought to have been in the capital; but sense of duty kept them at their station, although no work could be done there at the time. They trusted the people, and would not believe that they could harm those who, like themselves, had never done them anything but good. That feeling of trust kept them from taking advantage of the opportunity to escape, when they might have done so, even when they were urged to flee. They paid dearly for their error of judgement. The temper of a mob, but especially of a semi-heathen mob, is always an unknown quantity.

The martyrdom of the Johnsons, as it afterwards 


\section{Plotting and Massacre}

appeared, saved the lives of the queen, the French General and staff, the chief Malagasy officials, the traitors, and the European community at Fàravòhitra in the capital. For one of the tribes-the Zànakàntitra-in the neighbourhood of the capital, having branches in other parts of the central province, had formed a conspiracy to murder the traitors for betraying them and selling their fatherland; the queen and chief Malagasy officials for yielding to the French; the French General and his staff; and the European community for being on friendly terms with the French, and therefore in their minds, of course, in league with them against the Malagasy. The whole tribe was to assemble from the various villages by different routes at the weekly market at the capital, on a certain Friday, armed with knives and small meat-axes, which could easily be carried hidden under their cotton plaids. At a pre-arranged signal one party was to rush the French residency, another the palace, and a third Fàravòhitra, where the European community mostly resided, and all were to be massacred. As nothing of this kind was suspected by any one the plot might very easily have succeeded.

On the Monday, however, before the Friday fixed upon, two Malagasy officers-one of whom I knew well-and nine soldiers were sent out west to one of the villages of the Zànakàntitra tribe to arrest a bad character who was reanted; but who was being harboured by the chief of that village. On their arrival at the village they demanded in the queen's name that the man should be given up; but the chief refused to hand him over to them. Thereupon the Hova officers in an arrogant tone-Hova officers were nothing if not arrogant-declared that if he was not given up at once he would be taken by force together with the chief, and 
that both would be carried off as prisoners to the capital. The chief dared them to do so. Whereupon the officers and men drew their batons-they had no other armsand entered the village; but as they were completely at the mercy of the villagers, who were armed and ready to receive them, they were at once speared or cut down. Thus the eleven were literally cut to pieces!

Having committed so great a crime as the murder of the queen's officers and men they knew the consequences, and having once tasted blood determined not to wait till Friday; but rose at once, and sent off messengers to call out the other branches of the tribe. As they were not prepared to rise at a moment's notice, and many were from home, they were joined only by a few from their immediate neighbourhood. They marched next morning on Arivonimàmo, to seek, it was said, for an evangelist against whom they had a grudge, and who, it had been reported, was under shelter in Mr. Johnson's house. When they found that he had escaped they attacked the Johnsons and murdered them all. They looted their property and burned down their dwelling.

The awful news reached the capital on the Tuesday afternoon. It was the evening of the Fandroana, the annual festival of the Bath; but it was the saddest annual festival that had ever been held. General Duchesne and his staff were present, but it was more like a funeral feast than a festival. French troops were sent out west the following morning, and so the plot to massacre was frustrated.

Several members of the London Missionary Society mission had also very narrow escapes, myself, I believe, among the number. In the case of two members whose murder had been planned escape was due in one case to 



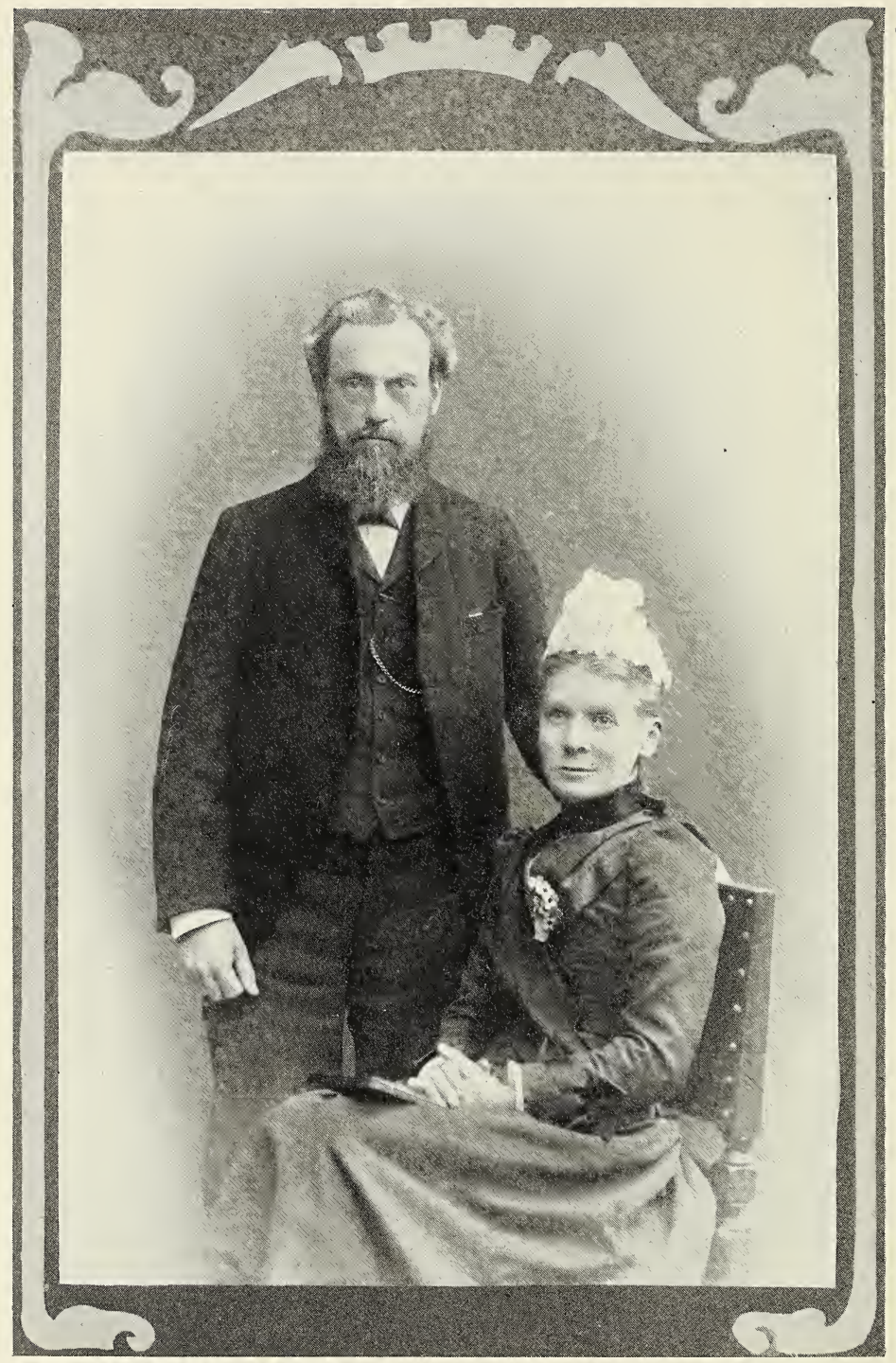

WILLIAM AND LUCY JOHNSON. 
the absence of the proposed victim, through his being called to the capital; and in the case of the other, no one was courageous or cruel enough to make the attack. We did not know of all this until afterwards, and it was well we did not.

General Duchesne, having accomplished his mission in the island, in the performance of which he had gained a name among the natives, as well as the Europeans, for justice and humanity, returned to France. On January $17,1896, M$. Laroche arrived in Antanànarìvo as the first governor-general of the island. He remained in office only until September of the same year. He was a man of high principle, with a love of fairness and justice, not only to Europeans, but also to the natives, which amounted to a passion. He was full of generous impulses, devoid of all ostentation, and very courteous and gracious to Queen Rànavàlona.

The Malagasy remember M. Laroche with feelings of kindliness to the present day, and his name will ever be associated with the emancipation of the slaves, which he accomplished by a single coup d'état.

One of the most notable days in the history of Madagascar was Sunday, September 27, 1896, for on that day there appeared in the Journal Officiel the sudden and, by the natives, altogether unexpected announcement that tous les habitants de Madagascar sont personnes libres. Thus by a single stroke of the pen, as it were, the time-honoured but execrable institution of slavery, which had its roots so deeply implanted in the fabric of Malagasy social life, was razed to the ground. It was M. Laroche, who was then on the point of handing the reins of government to his successor, General Gallieni, who thus struck off the fetters from ten thousand slaves. It had of course been known to all 


\section{The Conquest of Madagascar}

the Europeans that, from the time the island became a French colony, slavery was doomed, as being altogether incompatible with the principles of a people whose national motto is Liberté, Egalité, Fraternité.

The news of the emancipation spread like wild-fire, and had the decree been published in less distracting times-before the people had been crushed and cowedthe excitement caused by it would probably have given rise to serious disturbances, possibly to bloodshed. As it was, it was received with sullen calm by the slaveowners, and with great rejoicing by the slaves. Some of the latter, it is said, claimed their freedom before their masters even knew of the proclamation of the edict of emancipation.

There was an attempt made to revoke the edict of emancipation of the slaves, but, as the highest judicial authority in the island stated that that could be done only by an act of the French Chambers, nothing came of the attempt. M. Laroche was a noble-minded Christian gentleman, and had he been left long enough there, and his instructions carried out, he probably would have been able to reconcile the Malagasy to the French rule and régime, and thus 10,00o lives sacrificed during the rising would have been saved. For he soon gained the confidence of all, from the queen to the slave, and materially raised the opinion of French officials among all and sundry.

M. Laroche laboured under the disadvantage in the eyes of his countrymen of being a Protestant, and a convert from Roman Catholicism. Even before he left Paris his enemies were at work for his ruin. The army was then under the influence of the Jesuits, a section of the Paris press took the same side, the FrenchCreole colonists also took up an attitude of hostility 


\section{Malagasy Credulity}

towards him. His downfall was thus "only a matter of time. To add to his other offences he was accused of being 'in the pay of Lord Salisbury'! This was regarded as sufficiently proved by some, by his friendly attitude towards the British, and especially British missionaries. It was noted that he did not lift his hat every time he passed the tricolour, and that he attended the French Protestant service, held in a schoolroom lent by the British. He was known to be making efforts to learn the language of the niggers. The fact was he could not trust the so-called interpreters.

These were some of the enormities brought against M. Laroche, and so he was ultimately recalled. He had set his heart on freeing the slaves. He was allowed to emancipate them, and did so on the last day of his governor-generalship.

When the Malagasy found that they had been betrayed they were greatly enraged, and said: 'Well, the French may rule in Antanànarivo, but they shall not rule here,' and thousands rose against the new régime. This was a grave mistake, after things had gone so far; for what could they do with their spears, knives, and old flintlocks against French guns and rifles? If they had possessed arms, ammunition, and leaders, or any means of getting them, they might easily have wiped out the few French who were then in the island. Though it will scarcely be believed, yet there were some French credulous enough to think and say that the London Missionary Society supplied the natives with arms!

When the rising took place the French had not troops enough to cope with the situation, and reinforcements had to be sent for from Europe. In a very short time most parts of the central provinces were in a state of open rebellion, the backbone of the rising being the 


\section{The Conquest of Madagascar}

old heathen party, and the more disorderly masses of the population. For a time they were spoken of as fàhavàlo (enemies), but afterwards they were called mènalàmba (red plaids), because they coloured their cotton plaids with the red soil of the country, in order that they might not easily be recognized at a distance.

The rising really began within a few weeks after the French occupation of the capital, and had its origin in the rising of the Zànakàntitra tribe at Àmboànana in West Imèrina, after the murder of the Hova soldiers and officers, and the massacre of Mr. and Mrs. Johnson and child. The authorities had due warning of what was brewing, and if prompt measures had been taken, as they ought to have been, in the interests of all parties, the rising might have been put down very easily at the cost of a few lives; and thousands of lives-French and Malagasy - would thus have been saved. As the warnings came from the then hated British missionaries, who better knew the people and their feelings, they were only sneered at, and no attention paid to them. The French also had warning of the state of things in the south of Imèrina, but nothing was done, with the result that three French gentlemen, who went south then, were murdered on the road. They had slept at the London Missionary Society's mission house at Tsiafàhy the previous night, had been warned of their danger, and of the great risk they were running, but they only laughed. Next day they were murdered.

Those who rose were led by fanatical sorcerers and such like, and their object was to drive, not only the French, but all white men of whatsoever nationality out of the country, and restore the old political and religious régime. Their numbers swelled rapidly, especially as they forced into their service all the able-bodied men 


\section{Depredations and Atrocities}

they came across. Growing in audacity as they grew in numbers, they committed depredations and atrocities of all kinds, destroying all the churches and chapels they came across, burning the houses, threatening, and even taking the lives of some of those connected with the missionaries, while the rest were carried off into captivity. Soldiers were sent out to disperse them, and large numbers of Malagasy were killed as they rushed up boldly, time after time, to within a few yards of the French guns, trusting in the gun-charms, which they wore in profusion, and in the power of a certain idol named Ravòlòlona. This undisciplined rabble soon learned that they were no match for the troops sent out against them, and in a comparatively short time they tendered their submission. But soon after the insurrection was quelled in the west it broke out in other places. On some parts of the east coast the people rose, apparently not so much against the Europeans as against the Hovas, many of whom had for so long misruled and oppressed them.

'In the eastern part of Imèrina, and even beyond its outskirts, rebellion was also rife, and numerous bands of insurgents prowled about the country committing various acts of brigandage and violence. They were concentrated chiefly on the road leading from Tàmatàve to the capital. Many of the convoys of men carrying goods from the coast were waylaid and dispossessed of their loads, the bearers being shot or speared if they offered any resistance.

'Though the first insurgents in the west had given in their submission, others arose to take their place, and among various acts of violence committed by these desperate men must be reckoned, as the saddest of all, the assassination of our friends Messrs. Escande and 
Minault, Protestant missionaries of the Paris Missionary Society, who happened to be travelling through that part of the country at the time. In many distant places, too, anarchy reigned supreme, and for months the peaceable members of the community were at the mercy of prowling bands of lawless men, who, in the attempt to gain their ends, scrupled at no deed of violence. It became impossible for Europeans, and even for natives, to travel anywhere in the island without danger, a state of things the very reverse of that which had existed for so many years; for, except in certain remote places, the last thought that entered the mind of the traveller was that of danger. As, for a time, the French and native troops were insufficient to quell the revolt, the excited mobs drew nearer and nearer the capital, and for some weeks large conflagrations-schools, churches, or even whole villages set on fire by the rebels-were to be seen from the capital almost nightly. In one instance, a village was burnt within a mile of the capital, and no one would have been surprised if, at any time, an attempt had been made to fire the capital itself.

' By this time many parts of the country, and more especially Imèrina, were in a state of seething anarchy, such as had never before been witnessed in the island, and vigorous and severe measures were necessary to repress it. To the work of pacification General Gallieni set himself. The greater part of the country was placed under martial law and divided up into military districts, outposts of soldiers were stationed in the more disaffected territories, many of the native government officials, who were supposed to be implicated, were banished or shot, and the rebels were attacked at numerous points, the undisciplined natives being worsted at every encounter, large numbers of them perishing. 
Accusations were also rife, and, as is always the case at such times, many innocent persons along with the guilty doubtless suffered death. But this energetic action soon began to tell; the insurgents were gradually dispersed, or from stress of other circumstances returned to their homes, and the leaders of the movement gave in their submission one after another, until finally (towards the close of 1897) the whole country, except the remote west and south, had once again settled down into peace.

'The rebellion had brought nothing but disaster to all parties, and more especially to the natives. Their rice-fields had been neglected, and famine not only stared them in the face, but also, to some extent, overtook them. Their cattle had been raided, their rice-stores rifled, their houses looted, many of their villages burnt down, large tracts of territory practically devastated, and, most serious of all, great numbers of the people had suffered death, either at the hands of the rebels, from destitution, or from other causes. The rebellion had doubtless also something to do with the conversion of the island from a protectorate into an actual colony. The French too had suffered, for to them the repression of the insurrection meant the loss of life and treasure. The merchants, moreover, were losers, for during a considerable period trade was practically at a standstill. The various missions were also subjected to considerable losses. A large amount of property, including missionary residences, a sanatorium, a leper establishment, \&c., were destroyed. Of the churches which, however, belonged to the natives associated with the various missions, including the Roman Catholic, the Anglican, the Friends', the Lutheran, and our own, some $75^{\circ}$ in number were burnt down or otherwise destroyed, about 
500 of which were under the care of the London Missionary Society. Many of the pastors, preachers, evangelists, teachers, and prominent leaders in religious work, being connected more or less with foreigners, were made the chief objects of persecution by the rebels, and large numbers of them had to resort to flight in order to save their lives, leaving their property behind to be looted. Some of those that were caught, bravely refusing to forswear Christ and join in the revolt, were cruelly murdered.

'The authority of the Hova sovereigns, though farreaching, had never been more than nominal over certain parts of the island, and in some was even completely nil. In the highland regions of the interior, and all along the eastern slopes of the island, with the sole exception of a few districts inhabited by small tribes of Tanàla in the neighbourhood of Ikóngo, who were semi-independent, the authority of the queen was supreme. In the west, however, certain tribes, chiefly of the Sàkalàva, had maintained an independence more or less complete. Ruled over by innumerable kings and chiefs, they lived in a state of chronic rivalry and petty internecine warfare. Constant cattle-lifting and slave-raiding amongst the various tribes, which brought untold misery upon the inhabitants, had become an established curse, and travelling in the country was in general attended with considerable danger. A Hova military station existed here and there, but, for the most part, exerted little influence or authority over the surrounding people.

'Since the French have established themselves in the island, however, these turbulent tribes of the west have been almost entirely subjugated. Numerous small military expeditions, sufficiently large, however, to overcome the resistance of the incoherent tribes of Sàkalàva, have been 


\section{Turbulent Tribes}

sent on by the French in all directions-north-west, west, south-west-to occupy the country. These have had many encounters with belligerent bands of insurgents and bushrangers, who, though sometimes vastly greater in numbers, have, in nearly all cases, been obliged to yield to the superior powers of the disciplined troops, and ultimately, if not immediately, to give in their submission. Military posts have been established in a large number of important centres, and, except in a few of the more remote districts, peace and security now reigns.' 1

I Ten Years' Review. 


\section{CHAPTER XVI}

\section{TRIALS, TRIUMPHS, AND TERRORS}

'Surely the wrath of man shall praise Thee.'-PSALM lxxvi. 10.

NATURALLY the French regarded the rising against their rule as rebellion. It was very foolish of the Malagasy to rise against the French rule under the circumstances, but in the true sense of the term they were no more rebels than were the Scotch at Bannockburn, the French themselves at the siege of Orleans, or the Americans at Bunker's Hill. They had never, as a people, given in their allegiance to the French, nor accepted their rule. They and their queen had been basely betrayed, and their fatherland sold. As a people they had had no say in the matter.

General Gallieni was sent out as governor-general to put down the rising, which, many people thought, had been purposely allowed to assume the dimensions it did, in order that the régime of M. Laroche might be discredited, and his recall made possible. The right man was chosen for the work the French government wanted done. The rising was put down by drastic means, although it took longer to stamp it out than was at first anticipated. Martial law was proclaimed all over the island. The idea was to strike terror into the hearts of the Malagasy by the severest measures. The policy was not the wisest; for although it cowed and crushed the people, it did not really conquer them; 


\section{Smouldering Fires}

because you cannot conquer any people worth their salt by means of bombs and bullets, shooting and banishment. Such actions only send the iron deeper into their souls. Crushed, cowed, and seemingly subdued they may be, but never really conquered.

So long as you apply martial law, you can prevent the people from rising again, or from hindering you in carrying out your task successfully, and such a result may justify your measures of severity; but below, the fires are smouldering and will burst out afresh, unless other and more merciful measures are taken. A people can only be really and truly conquered, as God conquers human hearts, by love, mercy, justice, and kindly treatment. The iron was made to enter the souls of the Malagasy people, the Hova-' the haughty Hova '-in particular; and they were a sad example of the truth of the text, 'Pride goeth before destruction, and a haughty spirit before a fall.' Some of their tenderest and most patriotic feelings, traditions, and associations were trampled on by the expatriation of their queen, and the treatment of the tombs and ashes of their former sovereigns.

Much that was done then was most unwise, even as policy. The wisest and most politic thing to have done was to have tried every means of conciliating the people, and reconciling them to the new régime. The traditional opinion of many people in France in regard to the work of the London Missionary Society in Madagascar was that it was necessarily inimical to French influence in the island, and that its raison d'être was more political than religious in character, or, in the words of $M$. Le Myre de Vilers: 'Depuis cinquante ans rien ne lui a coûté pour arriver à ses fins: l'annexion de Madagascar à l'Angleterre.' To 


\section{Trials, Triumphs, and Terrors}

all who really know the Society this was a gross libel; but to many of our French friends, in whose ears it has been so repeatedly dinned, it appeared to be the truth.

General Gallieni, on his arrival in the island, appears to have believed in the truth of this tradition, a belief which was not likely to be diminished by the numerous signs he saw around him of the influence of the Society on the general community; an influence, however, which had only been gained by long years of patient and earnest toil and prayer. Taking for granted that this influence was of necessity antagonistic to the interests of the Republic, he determined to destroy it, if possible; but, in any case, to cripple it. The appropriation of the hospital (in which, though belonging to the Friends, the London Missionary Society was in part financially interested) was the first blow; then came the compulsory sale of the college and the normal school. In regard to the two latter buildings, however, it must be stated in fairness that, by way of compensation, the government promised to give on reasonable terms the freehold of the five memorial churches, as well as that of other property belonging to the Society. The sum of $£ 4,800$ was also given for the college buildings, and $£ \mathrm{I}, 050$ for the normal school.

This attitude of the government towards the London Missionary Society opened the door to all kinds of accusations against the natives connected with our mission. In addition to the time-serving informers among the natives, who sought to ingratiate themselves with the authorities, and to gain a position by sacrificing the good name of men of altogether superior character to themselves, it is not difficult to detect the hand of the Jesuit priest. Our evangelists, pastors, teachers, in fact 
the whole body of our adherents, and even our school children, were supposed to entertain disloyal sentiments, and also, in many cases, to be instigators and leaders in the rebellion. Even the missionaries themselves were not spared. Absurd charges were brought against some of them of preaching rebellion, and even of supplying powder and guns to the insurgents ; but it is needless to say that, in those cases where the accusers and accused could be brought face to face, these charges were seen quickly to vanish into thin air.

General Gallieni was surrounded by some of the worst advisers-both French and Malagasy-that he could possibly have had. It was little wonder, therefore, if at the first he committed serious errors of judgement, and made some most reprehensible mistakes;-for example, the shooting of the Governor of Tàmatàve upon a baseless charge trumped up against him by his malignant enemies to get rid of him.

The General was, however, far too shrewd and able a man to allow himself to be held long in leading. strings, or to have dust permanently thrown in his eyes. Still, it took him over a year to get at the real state of affairs, and to find out the facts for himself. He found that those whom he had sought to make tools of to harass the Protestants, and upset the work of the British missionaries in the supposed interests of France, were really making a tool of him, and a stalking-horse of France in the interests of Rome! He may have been as greatly deceived as the German professor, who published a book on Madagascar some time ago, so packed with fiction and false conceptions, that he gravely informs his readers that: "The London Missionary Society had a colony (sic) in Madagascar, 
and that 'the clerical gentlemen were the real rulers,'the late queen and prime minister seemingly being little better than their aides de camp!

The General told a deputation of missionaries who waited on him to pay their respects that a good deal had been done for the education of the people, but that religion had been a failure. There may have been more truth in that reflection than there ought to have been; still, he was neither an authority on religion, nor a judge in the case. He had not met with any of the really Christian portion of our people. His opinion on that and other points underwent a great change, after he had been round the island, and had seen for himself the difference between the heathen and the Christianized tribes. But it is from men who know as little about the mission field, and who are as ignorant of missionaries and their work, and as prejudiced against them as he then was, that too many take their ideas about foreign missions. No community would dream of impanelling a jury of cannibals to try a case of culpable homicide, or of appointing blind men judges at a flower-show, or deaf-mutes examiners for musical degrees. Even if they could and did do so, they would not act more irrationally than those who take their conceptions of missionaries and of their work from those who are destitute of all personal religion and all interest in missions.

As the general believed that we were political agents of the British government, he was determined-as he was reported to have stated-' to break the power of the British missionaries in Madagascar.' Until his eyes were opened to the real state of affairs he probably would have liked, had it been possible, to have expelled them from the island. Perhaps this result was hoped 
for by trying to make the place too hot for them, and their remaining seemingly useless. For this end the smashing of the machinery was resorted to. But then it was found that the power of the missionaries was a moral power, and could not be touched by such means.

The situation was very trying to all the members of the mission, but to some much more than to others. Two members gave up and left; and it was thought advisable, under the circumstances, that another should retire; but the rest kept at their posts and at their work, making up by deskwork for the work they were prevented from doing out in their districts. They were determined that, unless expelled, they would not retire until their furloughs were due. A few words would have secured expulsion; but as they had no anxiety to incur martyrdom for a word, they stuck to their work, and put up with much to which British subjects find it hard to submit.

In justice to the General it must be told that when he did find out his mistakes, and how grossly he had been imposed upon, he was man enough and gentleman enough to own his errors-though not in public. That could hardly be expected. He admitted that he had 'wronged the Hovas and misjudged the London Missionary Society's missionaries,' and reversed his policy with regard to both. It ought also to be told that he did his best to atone for the grave error into which he was led with regard to the Governor of Tàmatàve, by his treatment of the family, especially of the eldest son. The guilt of that 'judicial murder,' as a French gentleman called it, must be laid mainly at the doors of the 'good governor's' malignant enemies.

As he once admitted, the General went to Madagascar 
with the intention of stamping out Protestantism and making the people Roman Catholics, as the simplest way with the religious difficulty, and the easiest way of ruling the island, as he thought. From what he had seen of the so-called religion of the natives of the Soudan, and from what he had been told-that the people would be quite ready to change their religion, if he expressed a wish for it-he thought the matter would be very easily managed. He found that the religion of the Malagasy was of a very different kind from what he had met with in Africa. Their Protestantism was made of sterner stuff than he had imagined. The people, whose forefathers had died rather than renounce their faith at the bidding of their own sovereign, were not likely to renounce it now at the word of a European governor-general. Had he persisted in his course, a religious war would have been the result. Four-fifths of the people of the central provinces are Protestant.

General Gallieni and the French government came to see this, and wisely left the religion of the people severely alone. Religious liberty, which had been proclaimed before, became now more of a reality. The Radical government of M. Brisson, to their honour be it told, the day after they entered into power, ordered their colonial secretary to telegraph to Madagascar that the forty village churches which had been seized by the Jesuits in the Bètsilèo country were to be restored at once. This order had to be obeyed, and was a great blow to the arrogance and assumption of the Jesuits.

It was hardly to be wondered at, that it was almost impossible for the French people, the French officers, and colonists to believe that the British missionaries were not agents of the British government-even per- 


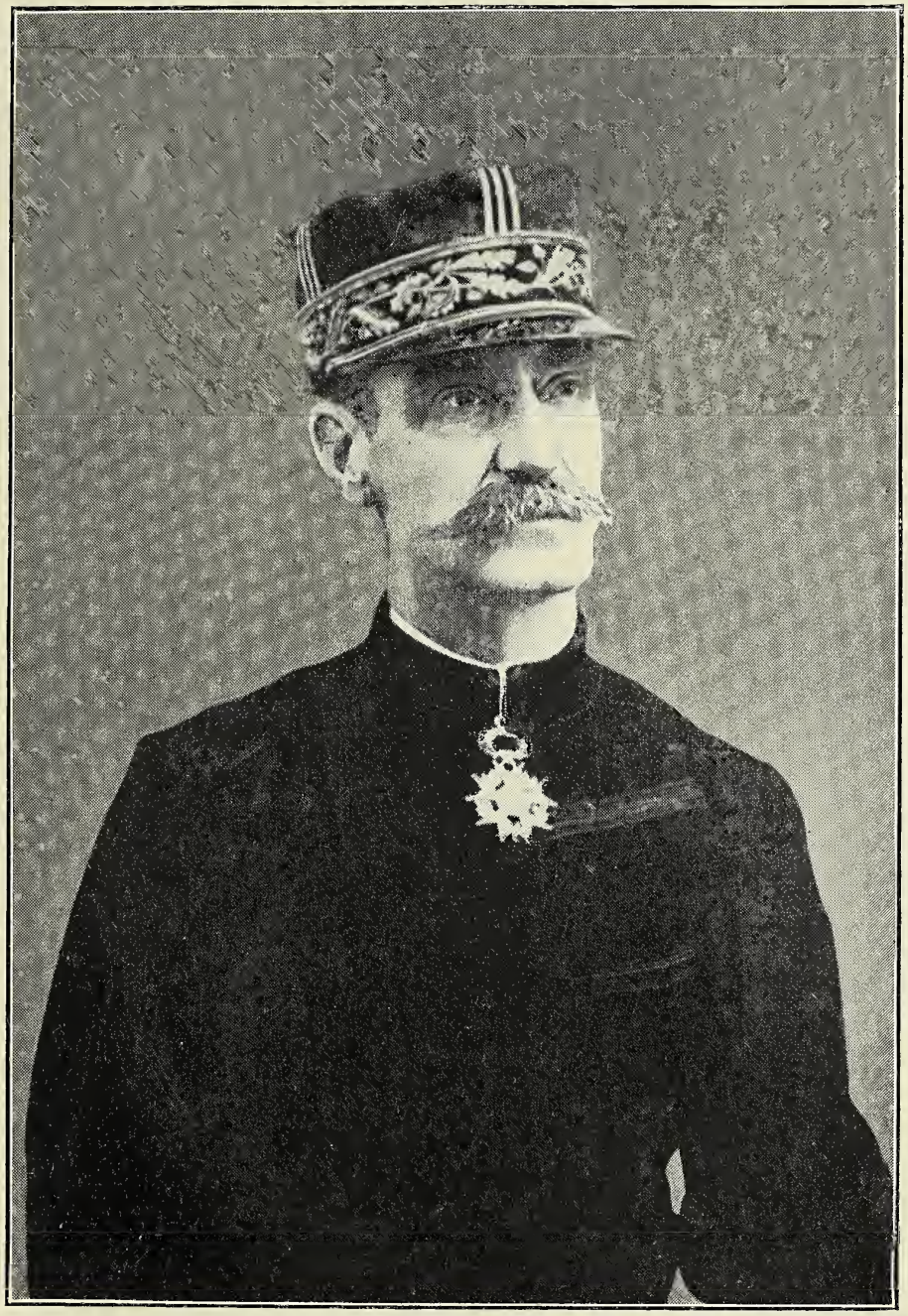

GENERAL GALLIENI. 



\section{Imposition and Deception}

manent officials of the French Foreign Office believed it!-and that their missions were not political agencies, under the guise of religion, as that of the Jesuits had been. At one time the Jesuits received a large sum yearly, afterwards reduced to ${ }_{15}, 000 f_{\text {., }}$ for services rendered to the French government. The Jesuits are banished from France, but supported abroad. When M. Laroche freed the slaves, they took the credit of the measure, though they had less to do with it than the British missionaries had; for they were consulted. and the Jesuits were not.

By deception they imposed on the people, and induced a large number of the freed slaves and poorer people to attend their chapels, and an immense number of their children to enter their schools. The freed slaves were told that the Jesuits had secured their freedom, and the common people were informed that France was a Roman Catholic power, and that if they did not become Roman Catholics they would certainly be regarded with the greatest suspicion, and might be shot as suspects. In some cases they were told that all the Protestants would ultimately be shot. While their chapels were filled and their schools crammed by this and other means, they drew up and sent to France their claims on the government for educational grants. Even for the children they really had in their hands, the grants would have been large; but according to their returns they made claim for more children than there were in all the schools-Roman Catholic and Protestant-in the island. How they made out these long lists can never be understood, unless they included the ignorant adults along with the children as their scholars.

The superintendent of the Norwegian Mission told 
me (and we had the missionary in whose district the thing actually took place as a fellow passenger on our last voyage home), that a Jesuit priest went through one of their districts, going from hut to hut with two small notebooks, a red one and a black one. Into the red notebook he wrote the names of the Roman Catholics, and into the black all the names of the Protestants, and all who would not consent to be Roman Catholics. 'Now,' he said, 'the government is going to make roads all through the island, to build railways, erect government buildings, and complete the telegraph, and all the work is to be done by fanompoiana (corvée), and it will all have to be done by the Protestants, and after it is all finished they will all be shot. The Roman Catholics will have no fànompòna to do, they will have a good time of it here, and then when they die they will all go straight to Paradise!' Among an ignorant and semi-heathen people, it was not to be wondered at, if great numbers professed themselves Roman Catholics in order to escape the hated fànompoana and shooting. When religious liberty became a reality, however, and the people found out the true state of matters, and saw that, on the whole, the corvee was very fairly dealt out, irrespective of religion, they ceased to be Roman Catholics by the thousand; and their opinion of their teachers underwent a most decided change, their language about them being much more energetic than elegant. Their hatred of them now is more bitter than ever.

The queen's uncle was shot along with the late Governor of Tàmatàve. Another uncle, Her Majesty's chief chaplain, her chamberlain, and several nobles were transported to the island of Réunion, while the rank and file suspected of sympathy or connexion with the 


\section{Heathen Doings and Charges}

rising, and those of the so-called rebels who had escaped, or who had thought better of their action and returned to their homes, were shot all over the country by irresponsible officers at Postes, who thought no more of shooting Malagasy than they did of killing vermin, until the central provinces may be said to have reeked with human blood. No doubt the rising was a most serious affair, and, in the interests of all, had to be put down; but that might have been done with less severity, and in a much more humane and merciful way. What took place at Fort Dauphin in the seventeenth century should have been a warning against undue severity.

As the heathen party was the backbone of the rising, some $75^{\circ}$ Protestant churches and Roman Catholic chapels were wrecked, 500 of these being connected with the London Missionary Society's Mission. One poor Roman Catholic priest, and several Protestant pastors, preachers, and evangelists were murdered, while many had very narrow escapes. A few were able to ransom themselves. All Bibles, Testaments, and other religious books found in the churches or in the huts of the pastors or evangelists were burned, while bonfires were made of the pulpits and pews of the churches. The heathen cast in the teeth of their Christian captives, that their teachers had sneaked into the island under the guise of being teachers of a new religion, and through them the fatherland had been lost. 'While we worshipped the gods of our forefathers,' they said, 'we had our fatherland, our own sovereign, and our own army; but you enraged the gods by forsaking them for the new religion, and praying to the white man's ancestor, Jesus Christ, and now we have lost all.'

It was in vain for the Protestants to try to convince them that their teachers had had nothing to do with 


\section{Trials, Triumphs, and Terrors}

the war or loss of the fatherland. As all the foreign teachers were white men and friends of each other, they were looked upon as equally guilty in the eyes of the heathen. "If the Protestant missionaries had not agreed to the war, and "piratical seizure" of the fatherland, why did they not appeal to their sovereign-lady to send her soldiers to help the Malagasy to drive back the invaders?' Such was the argument of the heathen. In the light of such sentiments, how absurd the tales circulated in France, and accepted by thousands of the credulous there as true! The British missionaries were accused of instigating the rising, and the London Missionary Society of supplying arms and ammunition to the rebels!

Many old scores were cleared off by malignant heathen and semi-heathen Malagasy during that reign of terror. Slaves who had been harshly and cruelly treated by their former masters took the opportunity of retaliating, and accused them of being connected with the rising; such people were at once arrested and shot. Debtors got rid of their creditors in the same way, while others cleared off many old grudges against Protestant pastors, preachers, evangelists, and even church members, by simply insinuating their suspicions to the officer of the Poste. After this these were marked men. Being found outside their huts or the village after dark, or returning from a visit, or from the market after dark, or some other trivial offence, was enough to stamp them as suspects, and they were arrested and shot. Arrested after dark, many of them were taken out and shot at daylight next morning, without the semblance of trial.

My wife and I were wakened a dozen times during those terrible months by the rattle of musketry about 5.30 in the morning, and we knew that another batch of 


\section{Protestant Pastors and French Officers}

poor Malagasy were shot as suspects. According to British law, every man is regarded as innocent until he is proved guilty; but according to French law any one can be arrested on suspicion, and must prove himself innocent. Many a poor Protestant pastor, evangelist, or church member, was arrested at night, brought out at daylight and shot, without getting the chance of proving anything, until even the French colonel-commandant of the capital said, 'there had been a great deal too much indiscriminate shooting'; and himself rescued some who were to be shot.

Some of the French officers treated the Malagasy very humanely, and some few even kindly. I knew one who confessed he could not sleep at night for thinking of how unjustly they had been treated; but, he added, 'I am determined they shall have justice in my jurisdiction,' and they had, with the result that the people adored, almost worshipped that officer, and wept like children when he left.

On the subject of the shooting of innocent Protestant pastors and church members, I content myself by allowing the late Pasteur B. Escande to bear his testimony, by quoting some extracts from the private letters to his wife, written during his stay in the island, which she has published since his murder under the title 'Nine Months in Madagascar.'

'October, 1896. You know the events which have changed the political and religious outlook in Madagascar:-M. Laroche recalled, General Gallieni given the charge in the interim of the general residence, finally the state of siege proclaimed in the disturbed parts of the island, notably in Imèrina and Bètsilèo, where the great mass of Protestant missionaries are located. 


\section{Trials, Triumphs, and Terrors}

'From the religious point of view this change of régime is greatly to be regretted. It is not that General Gallieni is in any way hostile to Protestant missions, or that we have not found in him the aid and protection which we had the right to expect from the representative of France. The General, on the contrary, has been very kind to $M$. Lauga and myself; very courteous also to the English and Norwegian missionaries, who had assured him of the loyal sentiments they felt towards France. On that side everything is satisfactory, and we have only to congratulate ourselves on our new Resident. It is not less the fact, however, that the Jesuits have profited by the new arrangements, in order to try and restore in Madagascar the France of Louis XIV. Under the administration of M. Laroche, and previously also, they had indulged in skirmishes, partial combats. To-day war is declared, "war to the knife," as an officer well acquainted with the situation said to us, and a war in which the Jesuits have an advantage over us in having at their disposal those redoubtable weapons which one calls calumny, lies, and deceit in all their forms.

'Notice besides, that the condition of the country put all the advantage in their hands. The exploits of the fàhavàlos, who pillage, burn, or kill all that they find in their road, and the rigorous measures taken against high Hova dignitaries, accused of complicity with them, have terrified the Malagasy population, which by nature is timid. This suited the Jesuits admirably. They run over the island in every sense, repeating everywhere that the Catholics will be protected by French troops, while the Protestants who are $A$ nglais will be considered as rebels, and accordingly put to death. 
'Still another thing: the General having issued a decree that, after the delay of a few months, French must be taught in all the schools, the Jesuits have hurriedly rushed out into the country, especially into Protestant villages, and there-thanks pretty often to the co-operation of local authorities-they have morally constrained the children to enter the French, i. e. the Catholic, schools, although the French taught in them is practically nil. The formality is a mere blind, that is all, but by means of it the innocent and simple are ensnared, and that is their whole aim.

'I have just spoken of the support that the Jesuits found among local authorities. I must explain myself. The advent of the military régime has naturally given much authority in the settlement of the country into the hands of military men. There are indeed some cruel administrators, especially in the undisturbed parts of the island. In Imèrina and Bètsilèo there are principally officers, some in the capacity of residents, some of commanders. Now one must say, that if the superior officers instil generally in religious matters (the only ones with which I occupy myself here) ideas of justice and impartiality which are those of the mother-country, this is not always so in the case of the inferior officers. Many among them allow the priests under cover of their authority to accomplish acts of suppression absolutely condemnable, while others even (I own it is the exception) make themselves their humble servants and favour their propaganda. If I speak thus, it is as a duty, not a pleasure. What is done here should be known in France. People must learn how the Jesuits gather the adherents, the number of which they do not fail to publish to the whole world. 


\section{Trials, Triumphs, and Terrors}

' Besides, proofs of what I bring forward are, alas, only too numerous. Not later than this week I had to go twice into the villages situated in the outskirts of Antanànarivo in order to come to the aid of the populations which were being terrorized by the priests. The latter, with the consent of the officers, had convolzed a kabàry (public assembly) in order to announce to the natives that there was no longer any hesitation possible, that if they wished to please France they must become Catholics and send their children to his school. This is not all. This week from four different directions, I might almost say from four cardinal points, news has come to us that the Jesuits have made simultaneously at these points attempts to seize Protestant churches in order to say mass in them, and to take possession of some school buildings belonging to our mission, in order to place in them their own teachers. They tell those who are willing to listen to them, that they are all powerful with the government, and, unfortunately, the support given to them by some officers and administrators lends a semblance of truth to it.

'We are in the midst of a plan of attack cunningly contrived, and in order to face it we are obliged to work with great activity. It will not succeed, however, that is indeed certain; for, thanks to God, there are in Madagascar some Christians who would die if need be for their faith, and on the other hand General Gallieni will do, we are persuaded, all in his power to prevent such attempts being perpetrated under cover of French authority. It is not less certain that these proceedings of another age will trouble and demoralize many of the population, which will give an excellent opportunity to the Jesuits for fishing in troubled waters. By what 


\section{British and Norwegian Missionaries}

I say alone you will understand that the churches of Madagascar are passing through one of the darkest hours of their history.

'You know already, but you will be glad to hear me repeat, that the English and Norwegian missionaries, in spite of the attacks of which they are the objects, rival each other in zeal in order to make France benefit by the moral and spiritual work which they have accomplished in this country. I have come into close enough contact with them to be able to affirm that they have accepted loyally and without any reservation the actual condition of affairs, that they work for the pacification of minds, and that they solicit only one favour - to be able to continue their work in peace, not with a political end in view, which they have never followed, but with the aim of converting the Malagasy people. They have spontaneously offered the French government their most devoted co-operation, and with their thousands of converts they represent a force morally incomparable. I do not hesitate to say, that to refuse this concurrence would be an enormous mistake from the political point of view, indeed almost a crime. For the honour of our country, as also for the good of our great African colony, we must believe that France will never make herself guilty of it.

'October I7. We are certainly passing through a solemn period in the history of Evangelical Christianity in Madagascar. The country is indeed being tried by fire and furnace. The threats of the Jesuits, who are supported everywhere by the officers, the chiefs of departments, and the commanders, their acts of oppression, their violence even, constitute a persecution in rule, comparable to that of the seventeenth century. I do not exaggerate when I say that in Madagascar we have 


\section{Trials, Triumphs, and Terrors}

gone back two centuries in the principles of liberty of conscience.

'Here is an example. One of the London Missionary Society missionaries having warned me that grave matters were happening in his district, I resolved to accompany him in order to restore things to order. It was a question of a Jesuit father, who had profited by the good disposition of the captain of Tsiafàhy, where there is not a single Catholic, in order to win over the inhabitants of the village. The day before he had summoned, by the help of the native governor, a great $k a b a ̀ r y$ and at this kabàry in which, a grave action indeed, the captain assisted, he announced that henceforth he would come to say mass every Sunday, that the adults were free to do what appeared good to them, but that in all cases the children must from the ensuing Monday enter the French school (by which is meant the Catholic one) which was going to be established in their village. Now notice, that there has been for many years a native school of the London Missionary Society which has never ceased working.

'After three hours of travelling to the south of Antanànarivo we arrived at Tsiafàhy. I went first, naturally, to the captain, in order to obtain some explanations from him, and to tell him the nature of our thoughts. He tried to show himself agreeable to me, but I had the impression that he was absolutely hostile, and that it was with his authority, perhaps even by his advice, that the priest had acted as I mentioned above. He did not conceal from me that he had assisted at the kabàry of the day before, or that he had promised the priest the loan of the former Protestant church, although it belonged to the London Missionary Society, for the purpose of saying mass the 


\section{Pastor Escande's Testimony}

next Sunday. These proceedings are all the more repugnant in that the house inhabited by the captain and troop is the missionary's own house, a very pretty one, beautifully sheltered by trees of every kind which thrive in the garden. The English missionary asked him for the right of occupying one room of his house each time he went to see his flock. The captain replied with a plain refusal: "You may renounce any hope of ever reoccupying your house," he said; "it is too well situated for the garrison not to keep it." I tried not to intimidate him and replied with calmness and firmness, bringing to my aid the circular of the general, which recommended the residents and commanders of the circles to deal with the greatest equity in the cases of pastors and priests. "The priest had his kabàry yesterday," I added, "I wish to have mine to-day. I wish equally also to have a witness that my words are not interpreted falsely."

"In the afternoon I stood before a reunion of roo persons, not in the public place, as it was raining slightly, but in a sufficiently large hall, in which the school actually was accustomed to meet. The captain himself was seated on my right, and Mr. E. on my left interpreted my words into Malagasy. I declared clearly that the French government gave liberty of conscience to all, and that those who said the contrary went against the orders of the General. I would not have been in the captain's place, as he knew quite well that I had right on my side. I have expatiated on this affair because it will give you a sample of the methods employed to combat Protestantism.

'Two events by which the situation is complicated further, are the recent order of the General concerning the teaching of French, and the existence of rebellion. 
All the natives suspected of having sympathy with the rebels are imprisoned, or put to death! It is by these means that the Protestants are terrified. Lastly, an officer of high rank, in addressing one of our best evangelists, who was hindering the priest of the district, said, while he showed the heads of some robbers: "You see these; before long a similar fate will be yours!" When there is no longer rebellion there will be a double danger no less to the English Protestants. They have suffered much from the ravages of the brigands, hundreds of their churches have been destroyed, missionaries have been massacred, and flourishing stations have been ruined. And, in spite of all that, the Protestants and the English are constantly affirmed as being friends of the rebels and enemies of France.

' From the bottom of my heart I admire those English missionaries who submit to all these humiliations, who let themselves be trampled under foot, and treated as outcasts, as pestilential, even in certain cases to such a degree that the members of their church dared no longer to touch their hands, and throughout all showing their greatness of soul by the patience with which they have supported all these insults for the sake of their congregations, and for the love of the Gospel. Their submission edifies me. It is worthy of such Christians as they are.

'Tuesday, 2oth. I have just arrived from a visit to a village Fenoarizo. The priest is revolutionizing the district by seeking to intimidate its inhabitants. I have proof that five Protestants have been put in prison under. pretext that they were rebels, and would be freed on the day that they declared themselves Catholics. Since then they have gone to mass. Last Sunday the officer in command there held a kabàry in the village near, 
and, interpreted by the priest, said that from henceforth it was necessary for all children to go to the Catholic school. I went to see him, and spoke to him as the case demanded.

'Wednesday. A very important affair has happened of which I must speak. It is concerning the arrest and execution of $M$. Ràtsimamànga, the uncle of the queen, and of $\mathrm{M}$. Rainàndrìamàmpàndry, the minister of the interior. The military authorities, impatient to stop the insurrection, thought that they would lay their hands on two of the chief men in the persons of these two important Hovas, as well as on Ramàsindràzana, the queen's aunt, who had shed a very great and beneficent influence over them. It was pretended that she was an accomplice of the rebels, and she was accordingly arrested; but on the intercession of M. Lauga she was only exiled to the island of Sante-Marie, while Messieurs Ràtsimamànga and Rainàndrìmàmpàndry were condemned to death by the council of war, and shot last Thursday. M. Lauga was present with them in their last moments. The ex-Governor of Tàmatàve died a Christian with a firmness and dignity truly admirable; which struck all those who saw him die. A scandalous incident was produced by the medium of a priest. $\mathrm{He}$ was introduced into the cell of the prisoners, although he had not been called, and while M. Lauga was discreetly removed, he re-baptized the uncle of the queen. Re-entering the cell, M. Lauga was very much surprised to see a flask of water, but to his questions the priest replied that it was nothing. Rainàndrìamàmpàndry shrugged his shoulders with a significant gesture when M. Lauga asked him whether his companion Ràtsimamànga had asked for baptism, in addition saying: "As for myself, I have not been baptized." A quarter of 
an hour after, Ràtsimamànga, accompanied by the priest, and Rainàndrìmàmpàndry by $\mathrm{M}$. Lauga, passed out to be shot. I ask myself if the government, in thinking to strike two blows, had not shot two innocent persons, and thus had deprived itself of two supporters who only asked to be allowed to use their influence in its service? One must cling to the hope of divine justice, which corrects sooner or later the errors of human arbitration.

'I have, accompanied by M. Lauga, just seen the queen. Poor woman! she calls forth all one's pity. Her principal supporters have been taken away from her. Her aunt, who was her confidante, yesterday took the road to exile; and now she has no one of trust near her. She trembles day and night, lest she should be accused of favouring the rebels, and so be expelled from her country. We said some words of sympathy which made the tears come into her eyes. Our words were interpreted into Malagasy by Ràtsimihàba, who visited France last summer, and whom $I$ had seen at Paris. I think that our visit did her good. Her principal wish was to have as soon as possible the wife of a French missionary near her.

'Antanànarìvo, Monday, November I6. Ihave important news to tell you: yesterday, Sunday, I was appointed pastor of the palace church. For a long time past the queen had shown a desire to have a French pastor at the head of her church. M. Kruger and M. Lauga, to whom she had offered the post, thought right to refuse, being here only on a temporary mission for a special purpose. I even had said to myself that, being here only for a few months, I could not accept the post, and that it was better to await the arrival of 


\section{Tempting the Queen}

a regular permanent pastor. Since the departure of M. Lauga, however, I have been led to think differently, and for this reason. It will not be giving you any news to tell you that the Jesuits are prowling round the queen to try and convert her to Romanism. During these last weeks they have frequently renewed their attempts. Bishop Cazet in one fortnight went to see her four or five times, to ask her, if not for abjuration, at least for some preliminary concessions. He begged her especially to attend mass, now and again, in the cathedral. This began to be rumoured about the town and country, and the "fathers" were already taking advantage of it for their cause. I know, on good authority, that the queen is very anxious to remain Protestant, and that she is annoyed by all these proceedings of the Jesuits; but her position is so precarious, so difficult, so delicate, that it is not possible to foresee what effect fair promises might have on her. Besides, it is not a question of the queen alone, but of the whole court. The Jesuits have been hard at work for a long time on the persons about the queen, and that not without success. M. Lauga, who had known the palace church in better days, was painfully impressed at his farewell meeting there to find that a good number of princesses were absent.

'Accordingly yesterday, Sunday, at nine o'clock, I betook myself to what is now my church. The building, situated close to the great palace of the queen, without being grand, has a certain style about it with its Gothic windows and the ornamentation running along its walls. On the left of the platform is the organ, on the right Her Majesty's throne, under an immense carved daïs. At the foot of the throne was one of the ministers, at the 


\section{Trials, Triumphs, and Terrors}

foot of the platform another, who presently led the queen, leaning on his arm, back to her home. Opposite the platform, at the end of the church, or rather just inside the front door, was a company of native soldiers, together with the royal band, which played at the beginning and at the end of the service.

'All the first part of the service was taken by the three chaplains of the queen, who were present for the occasion. Then, with one of our good Malagasy friends, Ramònta by name, as translator, I preached my sermon from Heb. xii. I, 2. After I had done, he who is called "the Malagasy Spurgeon " rose. I do not know all that he said, but he ended by proposing to the assembly to elect me as pastor. All hands were raised. I thanked Her Majesty and the assembly in a few words, then, in the name of the attendants, each of the three pastors shook hands with me in turn and made a speech. It was touching and affecting. All this lasted more than two hours. When no one remained in the church, the queen came down from her throne, and sent for me. I shall not tell you all the kind things she said to me, only this: "Now this church is no longer ours, it is yours. Dispose of it as you will, come to it as often as you like. To my house come when you think fit, I shall always receive you." She whom I had found so sad on my first visit with M. Lauga smiled and looked happy. Oh! how I should like to do her some good, and keep up her courage during the dark days she is passing through.

'Saturday, Nov. 21. I congratulate myself more and more that I consented to be appointed pastor to the queen. The General sent for me to express his pleasure at it; he even gave me to understand that this might perhaps save the situation. The queen's position is in 


\section{Departure of M. Lauga}

fact very precarious; should the difficulties last much longer, she runs the risk of being deposed. The General hopes that, thanks to my nomination, I shall be able to exercise a good influence over her and over her advisers. He asked me that prayers for France should henceforth be offered in the palace church services.

'The General's approval was of course very gratifying to me. Two others gave me great pleasure also-that of all the English missionaries, who said to me: "You have saved a great number of the churches of Imèrina, which would have been broken up if the queen had become Catholic"; and that of the superintendent of the Norwegian Missions, who told me in these very words: "You have saved our Norwegian Mission in Bètsilèo." The farther I go, then, the more I see what an urgent and important step I have taken.

'Antanànarìvo, Saturday, Nov. 21, 1896. So M. Lauga has left. His departure was a real mourning, not only for me, who lose in him a sure adviser and a true and trusty friend, but also for the Malagasy churches who appreciated the extent of the services he rendered them. All the good he and M. Kruger have done in Madagascar will never be known in France. I dare not picture to myself what would have happened to Malagasy Protestantism if our delegates had put off their coming. Humanly speaking, and with the help of God, they saved the situation. They gave back strength and courage to the native congregations; they upset a number of Jesuit plans which aimed at the destruction of Protestantism.

'Truth to tell, this departure has been in many respects very much to be regretted. To begin with, it deprives us of great strength and experience at a time 


\section{Trials, Triumphs, and Terrors}

which is perhaps the darkest and most critical that the country has gone through since the conquest. Moreover the Jesuits, who turn everything to good account, take advantage of this departure for their side. "You see," they tell the natives, "what we told you has come true. We had foretold that M. Kruger would be driven from Madagascar : so he was; then M. Lauga, he is gone. In the same way M. Escande will soon be driven away."

'Oh! those Jesuits! What infernal cleverness they have to take advantage even of what seems to turn against them! Lately a proclamation was issued by the government forbidding missionaries of any sort from taking part in politics. Well, in Malagasy the word missionary is always used to designate English missionaries, either of the London Missionary Society or the Friends' Mission. The Jesuits are only known by the name of mon perre-so that they had a trump card when they declared everywhere that the English missionaries are the only ones aimed at by the proclamation; that it was known that they meddled in politics, and that measures would be taken against them at the earliest opportunity.'

'How sad it is! I add, how humiliating it is for us Frenchmen to think that France is represented in Madagascar by such men! When one sees the means of intimidation and compulsion which they use to extend their propaganda, when one sees them threatening with the irons, or even getting native governors condemned as rebels, for the simple reason that they will not turn Roman Catholic, nor favour their fierce proselytism; when one sees them falsely accusing evangelists and Protestant teachers, in order to have them thrown into prison, and thus be able to lay hands on their chapels and schools, one is obliged to think the worst enemies 
of France in this country are not the fàhavalos (and they are terrible enough), but the Jesuits.

-Another cause of sorrow to me is the position in which the three pastors of the queen are placed. Last Sunday they were sent for to the staff-office, and there they were accused of inducing "dark and melancholy thoughts " in the mind of the queen-of not helping her to make the best of the present state of things. In one word, they were forbidden to put their foot in her house on ordinary week-days (they used to go and have worship with her every night). They were only allowed to go to church for service on Sundays. They are narrowly watched, and have been warned that, on the first complaint brought against them, they will be imprisoned for a while; and the second time, they will be shot! I was deeply grieved at this. I am convinced it is a Jesuit plot. Thanks to their intrigues, these honourable native pastors are kept under suspicion, and charged with misdeeds, so as to get them condemned. What success it would be for them, if they could say that the queen's pastors were discharged from their office, and put in irons! It would make all the other pastors of the land tremble, would discourage the Protestants, and perhaps even the queen herself. That is really their aim and object-to discourage the queen, bring her to bay, take away from her the last persons in whom she has confidence, and who bring her any comfort. They are in hopes that, wearied and disgusted with everything, she will finally throw herself into their arms to better her position. One might really believe in a return to seventeenth-century methods! It is a disgrace to France, that in the year of grace 1896 , and notwithstanding the good intentions of her government, it should be possible for such things to 


\section{Trials, Triumphs, and Terrors}

take place under her flag. I am humbled, heart-broken at the thought! Words fail me to express what I feel.

- A new detachment of black gowns has just arrived, and is beginning to spread everywhere. The Jesuits have sworn to stamp out Protestantism from the island; that is what they are fighting against, and not heathenism, which has still three or four millions of adherents. It is a fierce war, a hand-to-hand fight, of which no one in France has any adequate idea. The misfortune is, as I have said a hundred times, that part of the French army upholds them publicly, and favours their propaganda by putting her sword on their side.

'Here is a fresh instance: at Tsiafàhy, the captain has had the chapel divided into two by a low partition, so that it may be used for the two services. One Sunday lately, when the missionary, Mr. E., arrived for service, the priest was performing mass. $\mathrm{He}$ and his congregation waited patiently. When the Catholics had gone out Mr. E. began divine worship, but the Catholic teacher started playing the harmonium and making the children sing so noisily that it was almost impossible to hold a service. The captain declares to all that he considers Mr. E. as his greatest enemy, and that those who go and speak to that missionary will be looked upon as his personal enemies. This sudden exasperation is due, I think, to the fact that the London Missionary Society committee has written to the staff-office to have the house at Tsiafàhy given back to the missionary who wishes to return there, and the staff-office has granted it. The captain is perhaps also vexed to see that notwithstanding all his efforts the number of Catholics in his village remains very small. In the surrounding villages the situation 


\section{A Dark Future}

is also critical. A lieutenant was angry lately with an evangelist. The latter had received a note from Mr. E., explaining that he sent him in his name to carry on the religious and scholastic work of that place. He had shown this to the native governor before showing it to the lieutenant, who drove him away, saying: "There are no Protestants here; you have nothing to do in these parts."

'Antanànarìvo, Friday, January $\mathrm{r}$, 1897. A new year is beginning. What will it be for Madagascar? Shall we advance further into the dark night? Or shall we walk towards the dawn? We can repeat with the Mussulmans: "God alone knows!" I have just spoken of the dark night. We are in fact in it, at least from a religious point of view. Sometimes while listening to the complaints which reach me day by day from the four quarters of the country, I fancy myself carried back two centuries, into the later years of the great king. Those bands of men with no faith of their own, who go about in the pay of the Jesuits, spreading terror among the people by their lies and violence, threatening with death those who pray with the "English," and even in some places ill-treating the Protestant pupils, and beating their masters as they come out of school; those evangelists and native pastors accused of treason and cast into prison after the most cursory trial; those schools closed under pretext that the Catholic school is the only authorized one; those chapels used as barracks; and those others confiscated by the local authorities and given over to the priests; that quasi-royalty exercised by the Jesuits in the country, and thanks to which no governor, interpreter, or native magistrate is appointed without their advice and approval; those officers of every grade (if not all, 


\section{Trials, Triumphs, and Terrors}

at least a great number) lending the aid of their sword to that cassocked race to hasten the conversion of the heretics; does not all this remind one of some of the proceedings so dear to the heart of Père la Chaise and of the Maintenon?

'I do not speak of General Gallieni, whom I am pleased to recognize as doing all in his power to ensure liberty of conscience to all.

'Can all this take place, a hundred years after the Revolution, in a French colony? Alas, yes! it does happen, and in the present day under our very eyes, and yet more, as lamentable and heartrending. In future years, when the religious history of Madagascar is written, this period will be denoted by a name which will recall to us who are Huguenots sad but glorious memories, the name of "The Church under the Cross."

"There are a few high-born spirits here who foresee the danger, without, however, daring to point it out openly. I have been told that one of our most noted magistrates said recently to some friends: "They (the Jesuits) will go so far that the result will be that the decree of expulsion which is applied against them in France will be applied here as well." Those who think with him are quite the exception. The mass of the colonists and officials are under the yoke of the "good Fathers." They vie with each other in bowing and scraping to them, for they look upon the Jesuits as the predestined saviours of Madagascar. They consider them the only ones capable of wrestling against what is commonly called the English influence; although that influence (as far as it is exercised by the missionaries) is entirely on the side of France. And the priests feel their power, and they look upon their position as impregnable, hence their unprecedented boldness. 


\section{The General impartial}

'What is needed to avert the peril is a change of the public opinion; a firm and loyal campaign led by the French press, to enlighten our people on the doings of the disciples of Loyola, and to force the government to recall them to a more evangelical conception of the duties of their ministry.

'Caveant consules! If they are allowed full swing much longer, it will not only be a question of Protestant flocks dispersed or destroyed, but it will mean religious struggles of the severest kind. It means defiance, revolt, and hatred sown and taking root in the hearts of the Malagasy; the work of civilizing the great island (entrusted by Providence to our beloved France) thrown back, and may-be for ever compromised.

' 8 p.m. I had an hour and a half's interview with the General to-day. Although I did not obtain satisfaction on all points, I am none the less pleased with the interview. I was touched by the confidence the General showed me, by making me acquainted with a number of documents on the religious question. I saw once more that he wishes to remain absolutely neutral on religious matters. $\mathrm{He}$ means the orders that he gives on that point to be scrupulously carried out by his subordinates. He is perfectly in earnest, and declares himself ready to punish most severely those who favour either the Catholics or the Protestants. The misfortune is that he receives from his subordinates reports which do not correspond with the truth. He read me the letters he had received from the Minister of the Colonies, and the order which he had sent, on receipt of these letters, to the various residents and commandants of the circle. All would be well if these officers executed them loyally. Unfortunately they take their own way, and if complaints are brought up 


\section{Trials, Triumphs, and Terrors}

against them they know how to arrange that the inquiry should result to their favour. The General takes the word of his officers, and their accusers are put to confusion.

'Tanànarìvo, Tuesday, Jan. 26. The General wishes to remain impartial on religious matters, and he intends assuring religious liberty to all Malagasy, no matter to what church they belong. Unfortunately, there is an officer, whom I might name, who does his own sweet will with the General's orders. Again, certain governors, especially in the south of the Imèrina, are readier to obey the orders of the priests than those of the General.

- This storm, thanks be to God, does not rage with the same violence everywhere. There are even some parts where it is perfectly calm. I am happy to acknowledge that there are some residents and officers who are prompted by sentiments of justice and kindness, and who are in no wise desirous of making Madagascar into a settlement of Capuchin friars. That is how the district of Ambòhimànga, in spite of the efforts of the Jesuits, remains attached to Protestantism. Our schools there have fifteen times the number of the Catholics; three thousand against two hundred. Let us guard ourselves against despair; there are more than seven thousand men who have not bowed the knee to Baal. The Christian churches of Madagascar have bright days before them; we have only to do our duty, all our duty; that is, accept all the task it may please God to commit to us.

'I heard very edifying things at Tsìafahy about Captain Y., among others his views on religious liberty. Some time ago he assembled all the people of Tsiafahy, and said to them, "You know the French government 


\section{Strange Religious Liberty}

allows you liberty of conscience; you are therefore quite free to be either Catholic or Protestant; only, if you remain Protestant I shall shoot you." He said this in the presence of his soldiers; but, as you know, the latter cannot bear witness against their chiefs.

'Just one episode. Mr. J. had called to my notice the governor of a certain village as distinguishing himself by his Catholic zeal. Recently the "father" of Antànamalàza went there to pour out his usual calumnies against the English and Protestants. He had informed the people that those who remained Protestants should be subjected to a very heavy statute-labour, whereas those who became Catholics would suffer lightly, and the governor calmly gave his consent to these orders of the priest. As this village was on my way, I stopped there for a few minutes. The whole population, informed of my arrival, was waiting for me on the square, headed by the governor. I addressed a few kind words to them; then, in answer to my questions, the governor told me that formerly they were Protestants, but now, with the exception of the pastor and his family, all had become Catholics, so they had given the priest their chapel and their school. Now, I know that many are of a different mind, but dare not say anything, for fear of being ill-treated by the governor.

' Antanànarìvo, Sunday, Feb. 28. I am overwhelmed with sadness. . . . The queen left Antanànarivo at midnight for Réunion. I was not able to bid her farewell, as all was carried out with the greatest secrecy. This morning early, I received a letter from the General informing me of the event. Not knowing whether I was to hold a service at the palace as usual, I went there. A squad of soldiers were barring the entrance to the chapel. That is not all; one of the queen's pastors, 


\section{Trials, Triumphs, and Terrors}

J. Andrianaivoràvèlona, was taken by the police this morning at four, and cast into prison. What will happen to him? I shall soon know, for I shall go to the General, if needs be, to obtain justice for him. He is innocent, I am sure. Ever since I have known him he has been doing all he could to serve France loyally. He could not have done better than he did. The General has just sent me his orderly officer to ask my advice as to the procedure to be used with the arrested pastor. Between the two alternatives offered-court martial and exile to Réunion-I chose the second. My decision was prompted by the consideration that he would leave without being condemned, that is, with the hope of returning later on. Besides, he will be sent as the queen's chaplain. He will also be the pastor of the Protestant Malagasy who have been exiled to Réunion, and who are rather numerous. He will thus fill a double and precious ministry. Seeing he was thought guilty, and was to be punished, the situation I accepted was the very best. I think with sympathy of his two sons, one of whom is in Paris, and the other at Montpellier.

'Thursday, March 4. What I had foreseen for some months past has come about: the queen has been sent away. I was officially informed of it on Saturday night. The queen was only told after her dinner, at seven, and at one a.m. she left the capital, escorted by a captain and some soldiers. Every precaution had been taken, and with the greatest secrecy, so that the departure should take place without any disturbance. Next morning, on waking, the Malagasy might read on the walls of their city the proclamation of the General announcing the suppression of royalty in Madagascar. ... If what is declared is true, I only half pity the poor queen after all. For some months past her position has 
been most miserable. All those in whom she trusted had been taken away from her one after another. At Réunion she will be free, and will live quietly with some of her family who have joined her. She will also have her faithful pastor. I told you how he left. Moreover, the General, considering the information I supplied to him about the family, granted my request, and decided not to confiscate his goods. It would be well if this affair could be brought to light, and the lying accusations directed against this pastor exposed....

'The Jesuits gloat over the measures taken just lately; they take advantage of the state of affairs to thrust themselves upon the people more and more, and to make proselytes through fear. Naturally they distort the facts ; they affirm that the reason of the queen's departure was her refusal to become Catholic; for $\mathrm{J}$. Andrianaivoràvèlona's, that he was the most influential Protestant pastor. The uneducated country folk fall into the snare, and the good Jesuits rub their hands.

'Antanànarìvo, Monday, March 15 . I received a deputation from Bètsilèo begging me to go to their help. At Ambòsitra they are in a most critical position. It is impossible to conceive of what is happening there. The medical missionary of the place writes heartrending accounts. The Catholics seize all the churches by main force and plant crosses on them. They had placed one on a church entirely built by the London Missionary Society. The doctor himself took it off, to show clearly that the Jesuits had no right to that building. This almost brought about a revolution. Accusations were showered upon him, and he was brought before a tribunal composed of two Malagasy, who ordered him to replace the cross. He refused, and is determined to hold out, even if he is expelled. 


\section{Trials, Triumphs, and Terrors}

"The deputation told me the method of the Jesuit "father" in making converts. He sends bands of his partisans who bind the Protestants with cords, and belabour them with blows if they persist in their firmness. One of the deputies told me he had been seized by the priest's emissaries, raised into the air, then, when in that position he refused to turn Catholic, he was thrown violently to the ground and trampled under foot.

'Wednesday, March 24. To-day I went to Ambòhimànambòla. That village is already famous by the events which have taken place there. The governor does not lose one chance of threatening the Protestants. $\mathrm{He}$ is terrible when he makes up his mind. More than three hundred and fifty children had come from different villages, and a good many adults met together to hear me. Besides, many Catholic novices were listening at the windows. After service I questioned the children, to see whether they knew French. They repeated the Lord's Prayer and Apostles' Creed very fairly. Then we went to the teacher's house for lunch. There I heard all about the affairs of the place. The imprisonment of the evangelists has caused a great commotion, and the people are paralysed with fear. That is not all. The governor and mayor of Tsàrahonènana (both Protestants) have been arrested, as well as the pastor and our schoolmaster at Ihamàry, who were found guilty of not becoming Catholic. Seeing this, the boldest lose courage, and the priest of Antànamalàza brings them within the pale of the Roman Church.

- Thursday, April 8. Are we on the eve of new times? God grant it! In our dark sky it seems as though a little light were breaking. To begin with, the prohibition against the confiscation by Catholics of 


\section{Gleams of Hope}

our chapels is like the dawn of a new era. More than that, the General now seems disposed to make certain concessions to the English missionaries. During these few months he has been able to see their blameless conduct and the indisputable services they have rendered to the colony.

' The General has done still more with regard to our claims. I have already told you that the Jesuits claim ninety-one chapels in Bètsilèo, without counting those they have already seized. All those chapels are closed lately pending the General's decision. The latter has given us to hope that he would have them reopened and left to the Protestants, in accordance with the minister's orders.

"Further good news: the "father" of Antànamalàza has been removed. He is in Mandrìdràno, a day's march from here. The Friends' Mission have now the perilous honour of wrestling with that madman who did us so much harm in the Ambàtomànga circle. Another has taken his place at Antànamalàza. But he will need some time before he can gain the influence Father G. enjoyed.

"Saturday, April ro. The agents of the "fathers" were causing agitation at Andòhatànjona. The frightened Protestants no longer dared send their children to our school, and the Catholics boasted aloud that they were about to seize the chapel. Two or three times they had disturbed the services; in short, things looked very bad when, a couple of weeks ago, I went there myself. My visit had a very good effect. Seeing this, the Catholics were very vexed. They had the three chief members of the church arrested the day before yesterday, and yesterday I heard to my dismay that the pastor and teacher of Ampàngabè had been taken and 
led bound to Fènoarivo! They are supposed to have said that the English would soon arrive to drive the French away from Madagascar. I was preparing to defend them when I heard they had been brought with their accusers to Tanànarivo. I was reassured by this, especially as I heard their judge would be Colonel B., whose uprightness I know. This morning I heard they had been released. Not only have they not been condemned, but their accusers have been severely reprimanded. They have been warned that if they again attempt to disturb the Protestant congregation they will be condemned to six months' imprisonment. The judge added: "The priest who led you on to act in this way is bad ; beware of him."

"Jubilation of our people and confusion of the Catholics! they who thought they had only to raise their voices to get what they wanted! That is a verdict, and many more like it are needed. Nothing would convince our adversaries better that French justice is not an empty phrase.

'Tanànarivo, Monday, April ז2. The religious situation is greatly improving, at least in certain parts. General Gallieni's circular, dated March 26, forbidding the appropriation of religious buildings by the Roman Catholics, had produced a cessation. The Protestant congregations, hoping to be no longer disturbed in their worship, begin to take courage. On the other hand, the Jesuits, no longer able to intimidate the Protestant people by taking their chapels, have adopted another plan. More than ever (for the system has always been dear to them) they forge lying accusations against our most influential members (governors, pastors, teachers, deacons) in order to have them condemned. They know by experience that when the head has fallen the rest of the body does not offer much resistance. 


\section{Improved Situation}

'From all sides they are begging me to go to Bètsilèo, and it would not be surprising if I did accompany M. Minault. There will be ample work for two, and more. I shall, of course, wait till my colleagues have quite got into the work. It is important that our brethren in Bètsilèo should have a helping hand, especially those of the London Missionary Society, whose work has been three-quarters destroyed.' 


\section{CHAPTER XVII}

\section{THE END OF THE MONARCHY}

'As troops of robbers wait for a man, so the company of priests murder in the way.'-HOSEA vi. 9.

THE French Protestants took a great interest in our work, and rose to the occasion, and came to the rescue of Protestantism in Madagascar in a noble way. The interest in foreign missions on their part, and on the part of French-speaking Switzerland, has been of the greatest service to their churches. It has been a means of blessing to them, and revived what was dying out under the 'dry rot' of Rationalism, Unitarianism, and Infidelity. The income of the Paris Missionary Society has risen during ten years from $£_{15}$,000 to $£ 45$,000 ! Much of the money was given at first from motives of sentiment and patriotism, doubtless in the interests of 'our latest colony,' and the spread of the French language; but much also was given, and has been continued, from the highest and purest motives.

The Paris Society sent out a deputation to confer with us, see the work, and report on it. Then the late devoted and lamented Pasteur B. Escande came out to take charge of the portion of the work which the Paris Society took over, until reinforcements should be sent from France. During two years twenty-two missionaries were sent out to help us to save Protestantism. They 



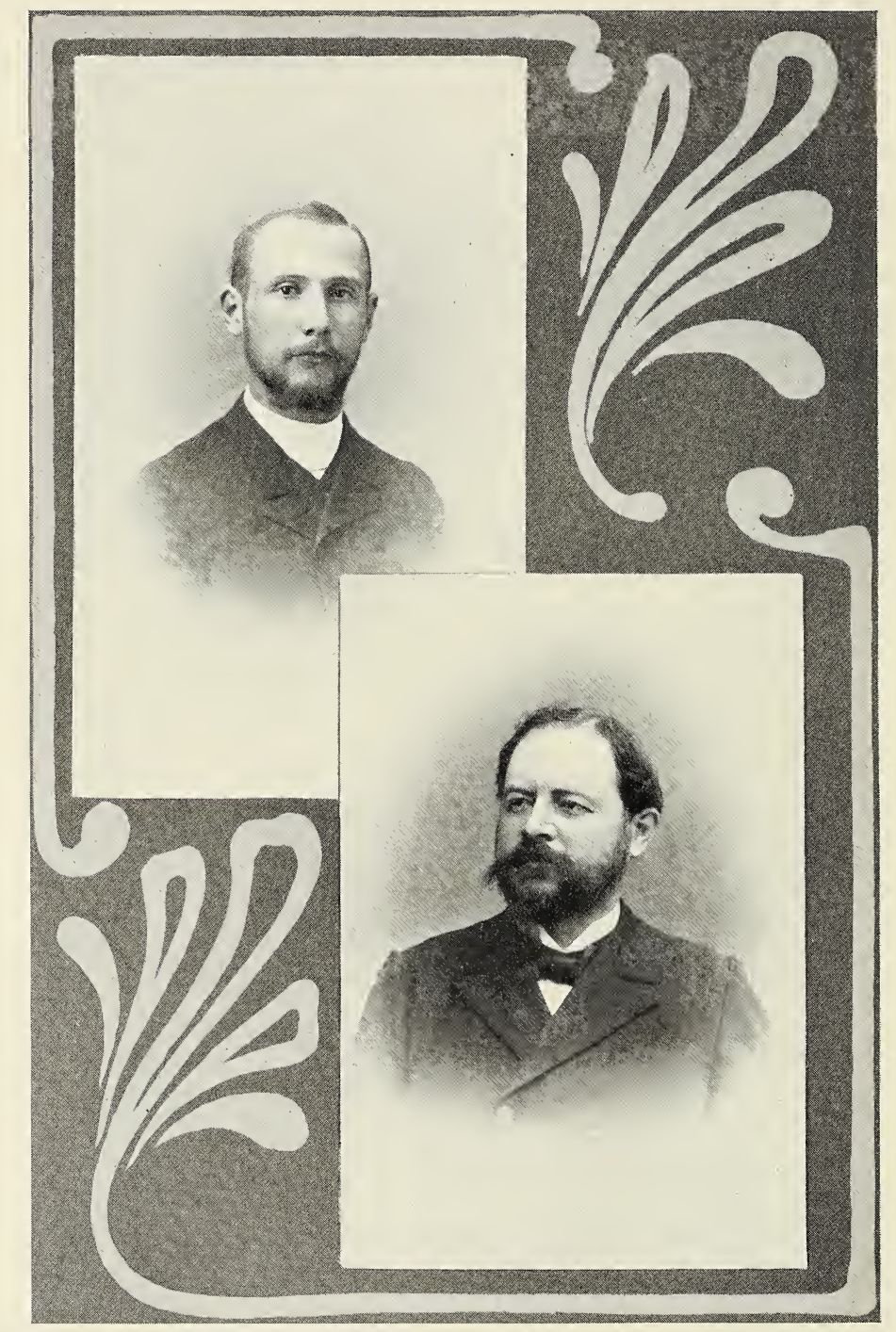

B. ESCANDE.

P. MINAULT. 


\section{The French Missionaries}

did a noble work in taking charge of our 800 village schools and saving them from the enemy. They worked remarkably well under the rather peculiar circumstances in which they were placed. They were handicapped in ways that British missionaries had never been: their nationality, the time of their arrival, following as it did in the wake of the army, the conduct of their compatriots, their connexion with the government-for they in common with the Jesuits received a government subsidy -these all tended to hinder their usefulness. They could not speak the language, and had to work with the aid of interpreters-a most unsatisfactory way of doing mission work. Fever too struck down some of them very quickly. Three couples were invalided home during the first two years, another couple the year after.

Their local president, his wife, and an unmarried missionary had to be recalled. Two of their best men (Pasteurs Escande and Minault) were basely and barbarously murdered. Most of them were very friendly and brotherly with us of the London Missionary Society at the first ; but pressure of some kind, from some quarter, seemed to have been applied, and they drew off from us, and became less friendly, until their directeur, M. Boegner, came out to visit the mission, and greatly helped to put things on a more satisfactory footing. Some who had brought letters of introduction to us from friends in France, and were most friendly at first, cut us afterwards when they met us, from fear or prejudice, or for some unknown reason.

There is a temptation to all young missionaries and ministers to forget that other men have laboured, and they have entered into their labours, and are reaping what they have sown. They are prone to underestimate the labours of their predecessors. Most of the young 
French Protestant missionaries ignored all that had been done by the London Missionary Society and its agents, in a way that was hardly in keeping with Christian courtesy or creditable to their Christian profession. We felt very hurt by their conduct, because it was so different from what we had expected, judging from the behaviour of the deputation sent out from Paris, and of M. Boegner, the secretary of the Society. It is only fair to them, however, to say that they may have been, and very likely were, deeply disappointed with the state of things they found in some of the districts handed over to their charge; partly, perhaps, because they had expected too much.

Three of those districts were the furthest behind, and most unsatisfactory in the island. The largest of them had been for years under the thraldom of five or six Palace Church evangelists, which meant Christianity by coercion. When they were removed the people returned - and they had not a long journey - to their old heathenism. The rising, the doings of the Jesuits, and the feelings generated while under coercion, brought them into a condition which was worse in many respects than their original heathen state.

On the morning of Sunday, Feb. 28, 1897, the capital was startled by the news that the queen had been arrested the previous evening, and carried off into captivity during the night. The plea afterwards advanced for such a harsh measure towards a helpless and inoffensive woman was that her presence in the island prevented those who had risen against the French from surrendering. This step was severely censured in France by the best and most merciful of the French people; but they were unable to prevent it.

'The last and crowning act in the annexation of the 


\section{Expatriation of the Queen}

island by the French was the deportation of the queen to Bourbon. Though it is impossible for those who knew her best to believe that she was in any way implicated in the rebellion, it seems certain that the rebels made use of her name as a battle-cry. The presence of a sovereign, moreover, in a French colony was an anomaly which sooner or later would have to disappear. Rànavàlona III, like her predecessor, had always had the interests of the people at heart, and was in entire sympathy with the educational and religious work carried on in the island. All detractions notwithstanding, she will be remembered as a good Christian queen, but one who, unfortunately, was under the influence of ill-advisers among her courtiers and relatives. And so she passed away into private life with a character unsullied, and in her retirement she doubtless enjoyed, though an exile, a peace and a freedom which formerly she could have scarcely experienced.

'The following is the translation of an extract from the proclamation published by General Gallieni at the time of her banishment:-

" "Since the government of the Republic has declared Madagascar a French colony, royalty has become useless in Imèrina. I have therefore invited the queen to resign her functions, and, at her request, have authorized that she retire to the island of Bourbon, where she will receive the greatest hospitality from the French authorities. The last few months have shown you what the words 'Madagascar, a French colony,' mean. They signify that France is henceforth the sole sovereign power in Madagascar, and that it cannot share its power with any one. It alone is mistress over the entire island. They signify also that France will bring to you its civilization, and will endeavour to introduce among 
you the principles which govern it, that is to say, justice, peace, and equality for all 1."."

The evening before the queen was arrested it was reported, that about 7.30 a French officer was seen to enter the palace yard, along with the arch-traitor. They were joined there by a Malagasy connected with the government press. The three entered the queen's private house, and sent in to inform Her Majesty that an officer from the Governor-General wished a private interview with her. She received them in her private apartments. The officer informed her that he had been sent to communicate a message of the gravest importance to her, and handed a paper to the Malagasy printer to read. The paper was an order for her arrest, and informed her that she was to be exiled to the island of Réunion, as a political prisoner, giving her four hours to pack her things and prepare for the journey! Unless she was ready to start by that time, she would be removed by force.

The Malagasy printer had not been in the secret, and hence had no idea what the paper contained. He read it until he came to the part in which Her Majesty was ordered to prepare in four hours for exile. Then the whole purport of the paper flashed upon him. He faltered, began weeping, and finally broke down so completely that he could not proceed with his task. The arch-traitor had to take the paper, and finish his treacherous work, by reading to his sovereign, to whom he had sworn allegiance, the order for her banishment from her fatherland and kingdom!

The queen was so thunderstruck by the order, that she failed at first to realize its meaning; but when she did, she threw herself at the feet of the officer, it was 
said, and grasping his legs begged for mercy. He informed her that he had no power to alter a word of the order, his instructions were simply to see it carried out. She then wanted to go to the General and appeal to him for mercy; but was told that that could not be allowed. She then became violently hysterical, laughed and cried by turns, and, afterwards sinking into a sullen and sulky mood, she refused to prepare for her journey or give instructions for preparations to be made.

In the meantime, when the order for Her Majesty's banishment was made known to the members of her household, there was great consternation; but some of them recognized the inevitable, kept their heads, and began making preparations for the journey. As the hour fixed for departure drew near, and the queen still remained obdurate and refused to move, the officer informed her that, ready or not ready, when the hour came she would be put into her palanquin; and this was what had to be done.

Rànavàlona III was committed to the care of another officer and carried away into exile. Thus the queen was hurried out of her capital during the darkness of midnight to a life of exile. And why? What had she done to deserve such treatment? Nothing whatever; absolutely nothing, except that she was the lawful sovereign of an island, which the French coveted and determined to appropriate. For notwithstanding that it was in a great measure through her own folly that her kingdom was lost (in following traitorous advice, and refusing to follow the counsel of her husband, the prime minister, or to give him a free hand); yet she had a passionate love for her fatherland, as most Malagasy have, and would rather have lived in poverty 
and obscurity there, than anywhere else in the world. Poor queen! hers has been a hard fate. Like Pomare, the late Queen of Tahiti, she was robbed of her lovely island home, treated as a captive, and will in all likelihood die an exile.

The murder of Pasteurs Escande and Minault was a great shock both to the European and the native communities. Pasteur Escande had been nine months in the capital with us, and had greatly endeared himself to all. Pasteur Minault had not been six weeks in the island. He had been appointed local president of the Paris Mission in Fianàrantsòa in the Bètsilèo country, and Pasteur Escande was accompanying him south to see the mission there, and get him properly settled. After this M. Escande was to return to France, and to his own work in Senegal; for he had only come out to Madagascar as a temporary substitute. He had seen and known more than any other European of the persecution of the Protestants at the hands of the Jesuits, knew more about the wholesale shooting of Protestant pastors than any one else, and had saved more from being shot than all the rest of the community. He was about to return to France, and intended to make known there what had been going on. It looks as though some were determined to prevent this at any cost.

It was reported in Europe at the time, that Pasteurs Escande and Minault had been murdered by fàhavàlo (enemies), and this was quite true. But the enemies were not the so-called rebels, or brigands, ordinary fàhavàlo. Among the seven men tried, found guilty, and shot for this murder, there were only two known bad characters, who had been among those who had murdered the Johnsons. The other five were Malagasy officials-a village governor, his secretary, a village schoolmaster, 



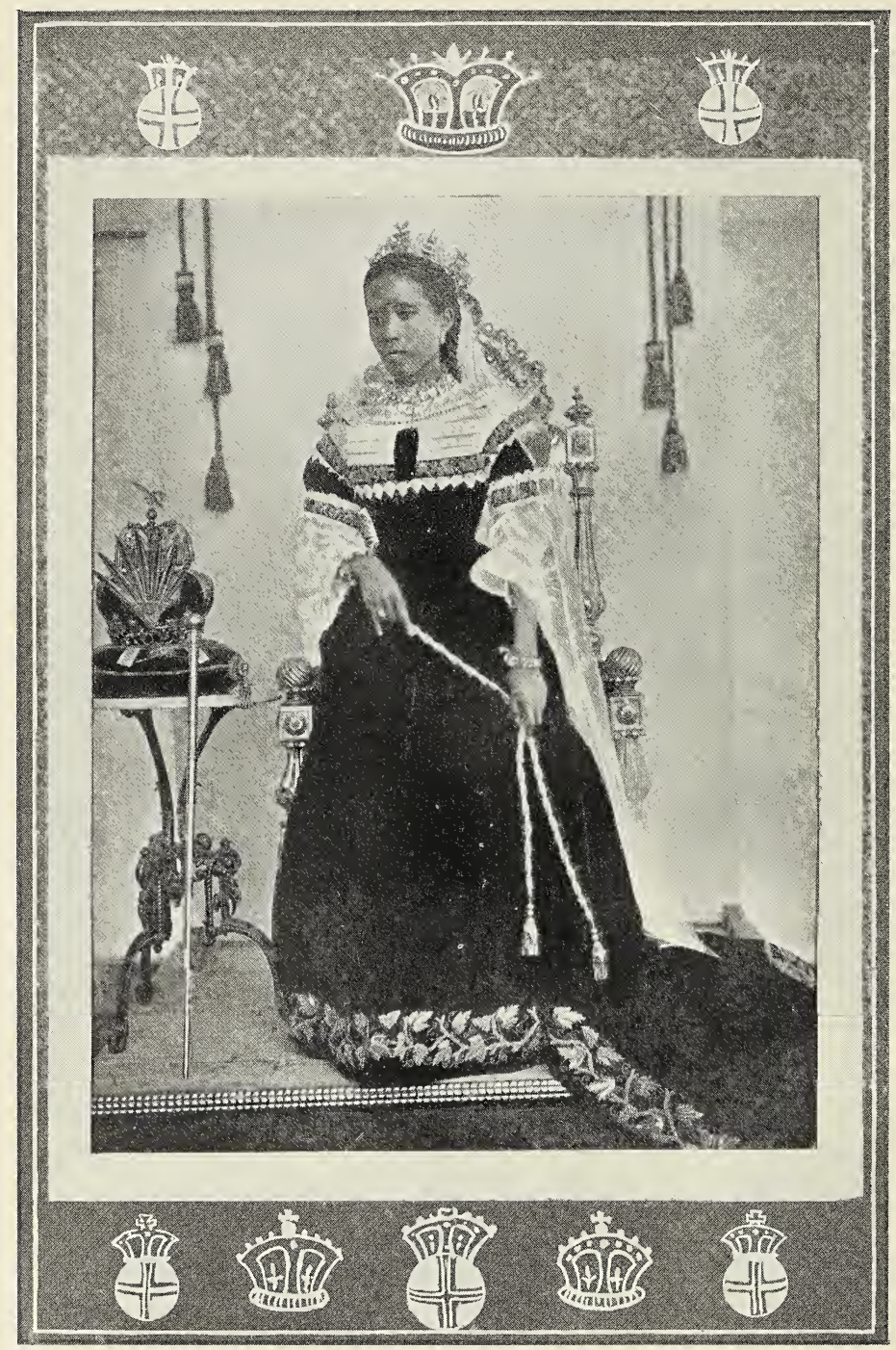

THE LAST QUEEN OF MADAGASCAR. 
and two other officials. The schoolmaster had actually received them into his hut in the village, had spread clean mats for them, had procured white rice for them, and had then gone off to inform the others, who were in waiting a little south of the village, of their arrival. In the European community there was little doubt as to who compassed their removal, and among the natives there was none whatever. Strange to say, some of the Malagasy knew that certain Europeans were to be killed that day, although few probably knew who they were. That some of them did know is perfectly certain.

The two pasteurs were murdered on a Friday afternoon, at a place some sixty miles from Antanànarivo. The news did not reach the capital till the Sabbath morning. On the Friday afternoon, about six o'clock, a native called at the house of Dr. B., and asked Miss A., who was in charge of it, if Dr. and Mrs. B. were among the Europeans that were to be killed that day. Miss A. was horrified at the question; asked the man what Europeans were to be killed, and where. But he could not tell; he only knew from others that there were Europeans to be killed somewhere to the south that day, and, knowing that Dr. and Mrs. B. had gone south, he wanted to know if they were safe.

How did that man come to know that there were Europeans to be killed in the south that day? It was quite impossible that he could have heard of their murder an hour and a half after it took place, some sixty miles away. He himself belonged to the Norwegian Mission, and hence his anxiety to know if Dr. and Mrs. B. were safe. It was afterwards found our that he had relatives and friends who were factotums in another mission. A Jesuit priest near Betàfo told his people the Sabbath before that troublers were coming 
to that part of the country, but God would meet them and stop them! How did he know that, and why did he mention it?

After their murder Pasteurs Escande and Minault were blamed by the French état major for not having asked for an escort; but they did ask for one, and were informed that there was no need for one, as there were no fàhavàlo (rebels) in that part of the country. This indeed was quite true. It came out at the trial that the murderers had surrounded the hut in which the two pasteurs had slept the previous night, but as it was not known whether they had firearms, they were not attacked.

I had a long talk with Pasteur Escande's horse-boy after their murder, and from what he told me I felt quite convinced that if either of them had possessed firearms, even if they had never used them, their lives would have been saved. He told me that they were fired at several times by the murderers with old flintlocks-old Malagasy government guns. They were such bad shots that they could not hit the horse even at a hundred yards! The bearers threw down Pasteur Minault's palanquin at the first shot, and bolted, as they knew the Europeans had no firearms. The murderers drew nearer, and kept on firing. At last Pasteur Minault was hit and fell, and when these ruffians saw they had no firearms, they rushed on them and dispatched them with their knives. The horse-boy caught Pasteur Escande's horse-he had dismounted when he saw his friend fall, and gone to his assistancemounted, galloped off, and gave the alarm.

Madame Escande published a selection of her husband's private letters to her while he was in Madagascar, under the title 'Nine Months in Madagascar.' The 
first edition was sold out in a short time, and all who wish to understand the condition of Madagascar at this time should carefully read this book.

A change gradually came over the policy which had been pursued towards us and our adherents up to this time. The eyes of the General had been opened to the true state of affairs, and to the fact that we were missionaries pure and simple. About the same time, the Jesuits received rebuffs they little expected. They had received a check from even the government of M. Milne. A letter was sent them by the colonial secretary, reminding them that the law for the expulsion of the Jesuits from France had not been repealed, and that as Madagascar had become a French colony, and so a part of France, if they did not alter their tactics and behave better, it might be applied to them even in Madagascar, and they would be expelled.

The late action of the government of $\mathrm{M}$. WaldeckRousseau with regard to the Jesuits and other Roman Catholic institutions in France was another blow to their influence and power even in Madagascar. This has been followed up by the action of the present government, so that while the work of all the Protestant missions is flourishing, the Roman Catholic Mission does not flourish. There are fewer adherents, and the Jesuits have less power to-day than they had before the war. The Malagasy have had their eyes thoroughly opened with regard to them and their aims. For this the Jesuits have themselves to blame. Boasting of their services to France in procuring the new colony of Madagascar, they have alienated the good will of the natives, whom they have taught to regard them as the robbers of their fatherland. Of course the Jesuits were furious at the proclamation of religious liberty. 
The Directors of the London Missionary Society sent out in 1897 the foreign secretary of the Society, the Rev. R. Wardlaw Thompson, and Alderman Evan Spicer of London, L.C.C., as a deputation to visit Madagascar, to have an interview with the General, and to talk over the situation and the work of the Society. The result was most satisfactory. The change that had gradually been coming over the spirit of the General's policy before their arrival was still more apparent after their advent. The deputation were able to save the girls' central school for the mission, to lead the General to understand, as he had never done before, the ends and aims of the Society's work, and to convince him that the Society had no connexion whatever with the British government, and had no ulterior motives for being in Madagascar. They were able to get the fullest concession of religious liberty for all London Missionary Society agents, and the compact has been faithfully carried out, while the General shortly afterwards wrote to H.B.M. consul acknowledging, and even praising, the good work that had been, and was still being done in the island by the Society's agents.

On our return from our first furlough in 1882 , we had been greatly disappointed at not being allowed to return to our old station in Vònizòngo; but after the severe way in which we had both suffered from fever there it was not thought advisable. Instead we were located in the capital. Some had always had the greatest anxiety to get located there, and never rested until they were. We, on the other hand, never felt drawn towards it as we did to our old home. Still, as years went on, it became plainer to us that there was work for us to do in the capital, some of it of a kind 


\section{Some Literary Work}

that I could not have done in Vònizòngo. By giving up my evenings mainly, and most of my spare time, to desk work, I was able to prepare and publish a number of translations, compilations, and books I had written, as I could not have done at Fihàonana.

In 1883 I was able thoroughly to revise the third edition of my translation of the Shorter Catechism, with proofs. I published my Exposition of the Sermon on the Mount, Religious Tales and Anecdotes, Scientific, Monumental, and Historical Illustrations of the Truth of the Old Testament Scriptures; $A$ Digest of the Books of the Bible with Notes; The Life and Times of Razàka, Pastor at Fihàonana; A Short History of the Scottish Covenanters; $A$ Short History of the French Camisards; Booklets I and II, The Children's Portion; a translation of Hodge's Outlines of Theology; and Dr. John Laidlaw's Foundation Truths of Scripture with regard to Sin and Salvation; and When the fullness of Time was come, and other Sermons, being the eighth small volume of sermons, the series representing 60,000 copies of ninetysix sermons.

During our last year I had to undertake the editorship of the Malagasy monthly, Good Words. This was done to save it from extinction, and as no one else would do it. During that year I was able to do the magazine some service, if in no other, from a commercial point of view. I persuaded our own people connected with the mother-church and country district of A-kànga to take $6_{50}$ copies a month; the Paris Missionary Society missionaries to take 500 , and others to push the circulation among theirs, and thus the circulation rose from a thousand to nearly four thousand monthly.

All these books, and also the magazines, were printed 
on paper granted by the Religious Tract Society of London. During the last thirty years that Society has made liberal annual grants of printing paper, and occasional grants of electrotypes to the missionary press in Madagascar. This timely aid has greatly assisted the important work of building up a Christian literature for the Malagasy.

It was of great encouragement to note the progress of our people during the time we had known them. They had grown in grace and in the knowledge of their Lord and Saviour Jesus Christ, and had been building themselves up in their most holy faith, by adding to their faith virtue, and to virtue knowledge, and to knowledge the graces that go to adorn the doctrine of God our Saviour, and by a life and conversation becoming the Gospel. There had been some sad changes in these later days-by the rising some 500 village churches had been more or less destroyed. A large number of villages had been burned, many pastors, evangelists, and church members had lost their little all, and some their lives. A large number of the people were carried off captive to the rebel camp, where they were kept prisoners, some of them for nearly two years. Some few escaped, some were shot for attempting to escape, while others were ransomed by their relatives.

When the rising had been put down, the captives returned to their homes, and the first thing they did was to re-thatch or rebuild their own huts and then their village churches. They recommenced their Sabbath services. Many had met for worship within the roofless walls of their old buildings for months. The children were gathered into the day-schools again. They sent on to me for Bibles and hymn-books, to replace what the rebels had torn up, or burned, and during three 


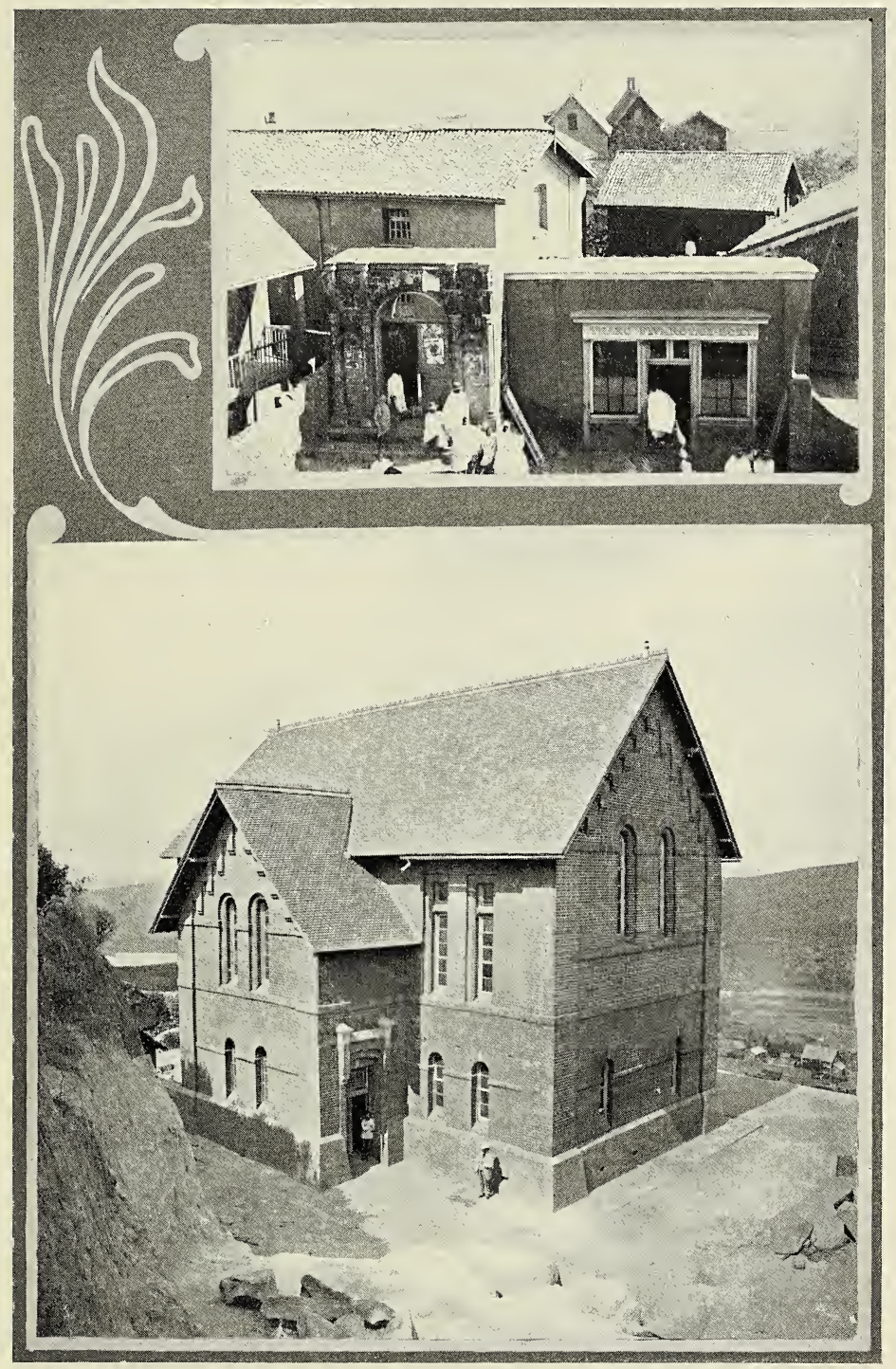

THE LONDON MISSIONARY SOCIETY PRINTING-OFFICE. THE NORMAL SCHOOL. 



\section{Fruits of the 'New Religion' $\quad 365$}

months I sold to the people of one section of our country district 300 Bibles and 500 hymn-books.

The people who returned from captivity came back in a state of absolute destitution. And it refreshed one's heart to witness the way in which the Christian people of the A-kànga district received them and helped them. They made collections of money, manioc, rice, clothing, \&c. for them. They helped to dig and prepare their rice-fields-a thing that many of them, poor creatures, were far too weak to do for themselves. They helped them to rebuild or re-thatch their huts and churches, and in many ways showed such practical sympathy with them in their distress as won the hearts of numbers of the merely nominal adherents to Christianity, and outsiders, for they said: "If this is a sample of the fruits of the "New Religion," it must be a good thing.'

In stating how these young Malagasy church members behaved towards their fellow members and others in their distress, I am but making known the grace of God bestowed on them. They had had great trials themselves, had suffered much, and had been robbed by the heathen rebels. Moreover, many of them who were formerly affluent had been reduced to poverty by the abolition of household slavery. But still they rose to the occasion in a way that was eminently to the credit of their Christian profession. Their zeal was an object-lesson such as many have never witnessed before; a great contrast to the selfishness of heathenism to which they had been accustomed. Many were thus led to take a much deeper and kindlier interest in the 'New Religion.'

I managed to engage a very clever young fellow, a French corporal, and a Bachelor of Science, who was freed from military duty, to teach French in the 
A-kànga High School for Girls. He came to our house two afternoons a week to read French with me. We read through the Gospels, the Acts, and the Epistle to the Romans together. When we came to the account of the Crucifixion in the Gospels, that young fellow broke down, burst into tears, and weeping, said: 'Was it really like that ?' I asked, what? When he answered: 'The Crucifixion of our Lord.' 'Have you never read about that before?' I asked. ' No,' he answered, 'I have not; for I have never seen a Bible before in my life until I saw this one of yours!' As I have mentioned, that soldier was a Bachelor of Science, a German scholar, and a fair English one, and yet he had never seen a Bible in his own or any other language before. He was a Roman Catholic, but by no means a bigoted one.

When any of the French Protestant missionaries preached for me at A-kànga, he was always there to hear them, and seemed to enjoy their discourses very much. When he told me that he had never seen a Bible before I said I would be very pleased to make him a present of one if he would accept it. He said he would only be too delighted to get it. I gave one to him and also to his companion. I often asked him if he read his Bible, and he said he always read it at night, when he could find it; but he explained that he could not always find it, as his comrades, when off duty, took it, read it, and were deeply interested in it. He told me that they thought that we British missionaries could not be such bad men as the Jesuits said, or we would not give such good books to the 'niggers' to read. They thought, of course, that it was vain and foolish labour, as nothing could ever be made of the 'niggers'! I afterwards gave my friend a copy of a small volume of Mr. Spurgeon's sermons in French, 
and some other booklets; and I heard from him several times after he left the island.

Some time after the war and annexation of the island, a consignment of Malagasy New Testaments was sent out by the British and Foreign Bible Society. They were being passed through the custom house, in the presence of the Society's agent. The late Malagasy government had allowed all copies of the Bible into the island dutyfree; but the French authorities demand duty on them. One of the French officers took four copies out of one of the boxes. The agent asked him why he did so, and he answered: 'To have them translated to see that there is nothing in them against the French!'

In a sermon once I told of an old friend of mine in Scotland, who, I said, made clothes for Jesus Christ. One of my local preachers present was very much impressed by what I said, and he retold what he had heard, when preaching in one of the village churches in the neighbourhood of the capital. A shoemaker, a member of that church, was struck by what he heard, it seems, and said to himself: If that European tailor can do his work for Jesus Christ, why can't I do mine for Him; if he can make his clothes for Him, why can't I make my shoes for Him? and he determined he would.

Some months afterwards he called on the local preacher and told him the following story. He said: 'I have been a church member for some years, but it never struck me that my religion should have any bearing on my daily work. I thought if I went to church twice on the Sabbath, and to the Communion once a month, gave a little money to the collection, and read my Bible and prayed sometimes, that was all that was required of me. But that story you told of 
that European tailor has impressed me, and threw such a flood of light upon my duty as a Christian man, that I at once saw that I had been all wrong in the past, and that I ought to do all my work for Jesus Christ.

' Formerly I used to buy the cheapest leather and thread I could get, rush home, make my shoes as quickly as possible, and then off to the market to sell them for as much as I could get-my only anxiety being to get as much money as I could, and as quickly as possible, however badly my work was done-that did not trouble me at all. That story, however, quite startled me; I saw how mistaken I had been, and what my duty was for the future; and I determined to do all my work for Jesus Christ, and I have done so. I now buy the very best leather and thread I can find, and I put the best work I can into all the boots and shoes I make. I make them now just as if Jesus Christ had ordered them, and was standing by watching how I made them, and waiting to put them on as soon as they were finished. I don't make so much money by my work as I did formerly, but I am very much happier, and the people are coming to know the kind of boots and shoes I now make, and I have as much work as I can possibly do. I can't preach or teach, but I can make boots and shoes; and that I do as well as ever I can for Jesus Christ's sake, and in the hope that in that way I may adorn the doctrine of God, by a life and work such as will do credit to my profession of Christianity.' 


\section{CHAPTER XVIII}

\section{THE TRIUMPH OF THE GOSPEL}

'He shall not fail nor be discouraged, till He have set judgement in the earth ; and the isles shall wait for His law.'-ISAraH xlii. 4.

(" $\mathrm{He}$ shall not burn dimly, neither shall His Spirit be crushed, until He has placed the law of Jehovah on the earth; and for His teaching the nations are waiting.'-Nere Translation.)

UNDER French rule everything in Madagascar has been changed. Some of the changes are decidedly beneficial, others are not, and some are such as to cause the profoundest sorrow.

'The whole administration of the island has now been completely organized, and that of course on French principles. What strikes an Englishman as strange in this administration is its elaborate redundancy, especially when the primitive character of the native community and the paucity of colonists are taken into account. If the social condition of the people were ten times more complex than it is, and if the commerce of the island were multiplied even a hundredfold, the number of officials, European and native, would be quite ample to meet all the needs of the community. First of all, there is the civil administration, which is divided up into sixteen or eighteen departments, including those of public works, mines, education, exchequer, landed estates, forests, agriculture, police, topography, taxation, post and telegraph, \&c. Numerous law courts, both 
French and native, have also been established, as well as a health department, with hospitals, dispensaries, military infirmaries, and ambulances. Then there come the chiefs or administrators of provinces, fourteen in number, with their subordinates and a whole tribe of native functionaries; and added to all these there is the army of occupation, many parts of the country being still under military control. It is certainly a great advantage, especially for Europeans accustomed to such things, to have regular postal and telegraphic communication, not only with different parts of the island, but also with the outside world. Such things were formerly beyond the hopes of the most sanguine; and when the capital is provided with electric light and a proper water supply, and railway communication with the coast has been established, all of which are at present in contemplation, even the dreams of the most expectant will have been more than realized.

'As to the present attitude of the French authorities towards our mission, there is a complete and radical change. Their policy is all that we could desire. We have the most absolute freedom to go about our work in our own way, and religious liberty now exists, not merely in theory, but in actual reality. We feel sure that General Gallieni ultimately became quite convinced of our loyalty, for, before he left the island, he had not only changed his policy, but gave many evidences of a friendly feeling towards us. His successor, General Pennequin, also has shown us nothing but courtesy and kindness. General Gallieni returned, and so, through God's overruling providence, the mission has been released from a perilous situation and placed again on a footing of freedom and hopefulness; and if this new and better policy continues, the missionaries of the Society 
may still look forward to many years of useful and successful labour in the cause of Christ in the island ' '.

Everything points to the necessity of Christian workers doing more in the future than has ever been done in the past for the moral and spiritual elevation of the people. The military band which now plays on the Sabbath afternoons in the centre square of Antanànarivo gives the note to society; and the vast crowd which gathers to listen to it are not adverse to march to its music. All branches of manual labour are carried on on the Sabbath, while Sabbath markets, open shops, and stores are general.

The Malagasy in their heathen state were notoriously given to sexual immorality; and one of the many effects of this evil trait in their nature was painfully evident in the prevalence among old and young, rich and poor, of loathsome forms of disease. One of the most serious, and one of the most difficult duties of the missionaries, and of the more enlightened and earnest of the native Christian leaders, has been to wage war against this form of vice, and to create a new and healthy public opinion on this subject of moral purity.

We had in a great measure succeeded in this direction. A fairly strong public opinion had been created, favoured by the late queen and the prime minister. Old heathen customs and vices were hiding their heads, and many were becoming ashamed of what was formerly their pride and boast. When the war came, followed by the annexation, the floodgates of immorality were thrown open; and under the new régime vice and immorality are openly recognized. The gaily dressed paramours of foreigners have lost all sense of shame, and go flitting to and fro in the capital, and travelling with French officers

1 Ten Years' Review.

A a 2 
the country over to and from the coast. The Jesuits seem to take no notice of this shameful state of things. With Montesquieu they seem to regard morals as a mere matter of climate, and speak of such conduct as colonial morality. All true Christian workers will have to contend everywhere in the future against a much stronger tide than ever before of countenanced and patronized irreligion and open sin.

French civilization is more adverse to the progress of mission work, evangelical religion, and morality than even some phases of heathenism; but perhaps we ought to be thankful that things are not worse than they are. They are not so bad now as at one time we feared they would be. The quiet Sabbath day is a thing of the past, as bands now play, games and races go on, theatres are open, and there have been even bull-fights on the Sabbath. On the part of the missionaries this will mean the need of greater spiritual strength, a closer and more constant supervision of the churches than, owing to their number, they have been able to give in the past, and a much more direct and personal contact with their native agents and fellow workers.

The new régime has served as a sort of dark background-although it has been at a terrible cost-to Protestant mission work. The Malagasy themselves said: 'We were bad, and our forefathers were bad; but they and we too were poor, ignorant, dark-minded fools; but that educated men, professing civilization, should behave as these men do is shameful in the extreme. How different their lives and conduct from that of the other foreigners! But is not the one class Protestant, the other Roman Catholic? In the one case we see the fruits of Bible teaching and religion, and in the other that of Jesuit teaching.' 
In the days of Hova supremacy, although the London Missionary Society Mission was in no sense connected with the Malagasy government, and although its missionaries did their utmost to prevent any such connexion-even going the length of informing the prime minister that they would sooner leave the island than consent to his directing the affairs of the churches in any way-still, it enjoyed a certain prestige from the fact that the church of the sovereign and of the leading people of the State was of the same order as those under the charge of its missionaries. Moreover, the congregation known as the Palace Church, which was in close touch with the court, and which very jealously guarded itself from all interference on the part of any European missionary, had a missionary organization of its own, which brought government pressure to bear on the people for the furtherance of Christian work, by means of the so-called Palace Church evangelists who were supported for political purposes.

Hova governors and officials were often much more zealous than intelligent in their ideas of Christian life and duty. There was abundant evidence to show that in many cases they were not content with the influence of personal example; but did not hesitate to make use of their official authority in country districts, and at outposts among other tribes, to compel the people to erect churches and attend the services. In most cases in the central provinces this was done at the instigation of a Palace Church evangelist. As a consequence of all this, and of the queen, prime minister, and chief officers professing Christianity, there always was a large number who went with the stream, and who swelled the list of members and adherents, without adding to the strength of the church. They rather added to its weakness, as 
nominal members and adherents always and everywhere do. This state of things, thank God! has passed away for ever. Never again will it be possible for the London Missionary Society or any other mission to enjoy the very questionable advantage of a worldly prestige, which seemed for long to be one of the greatest helps; but in reality, one of the greatest hindrances and perils which can beset the propagation of the Christian faith. Henceforth the London Missionary Society Mission and all other missions will have to depend for success entirely upon God's blessing, on the moral earnestness and spiritual power of their agents.

Under the Hova government, the pastorate of the churches was an office aspired to by many; not for the stipend-for there usually was none-but because it gave exemption from the hated fanompiana, or unpaid government service. In addition to the pastor, there were in most places a number of local preachers, who took their share of the service with him. Among them would generally be the village schoolmaster and some of the deacons, or other leading men of the congregation. Where there was a trained evangelist, he generally took the oversight of ten or fifteen village churches, while the missionary had the superintendence of the whole district, with its sixty or eighty churches and schools. Under the new system there is a great change in the position of the Protestant pastors. They no longer enjoy special privileges, but are required, like others, to render a certain amount of service annually to the State, or pay for exemption. The demands made by the State upon the services of all and sundry are considerable, and hence the number of local preachers has greatly diminished, and in some places ceased altogether. If, as is to be hoped, the churches generally rise to the recognition of 


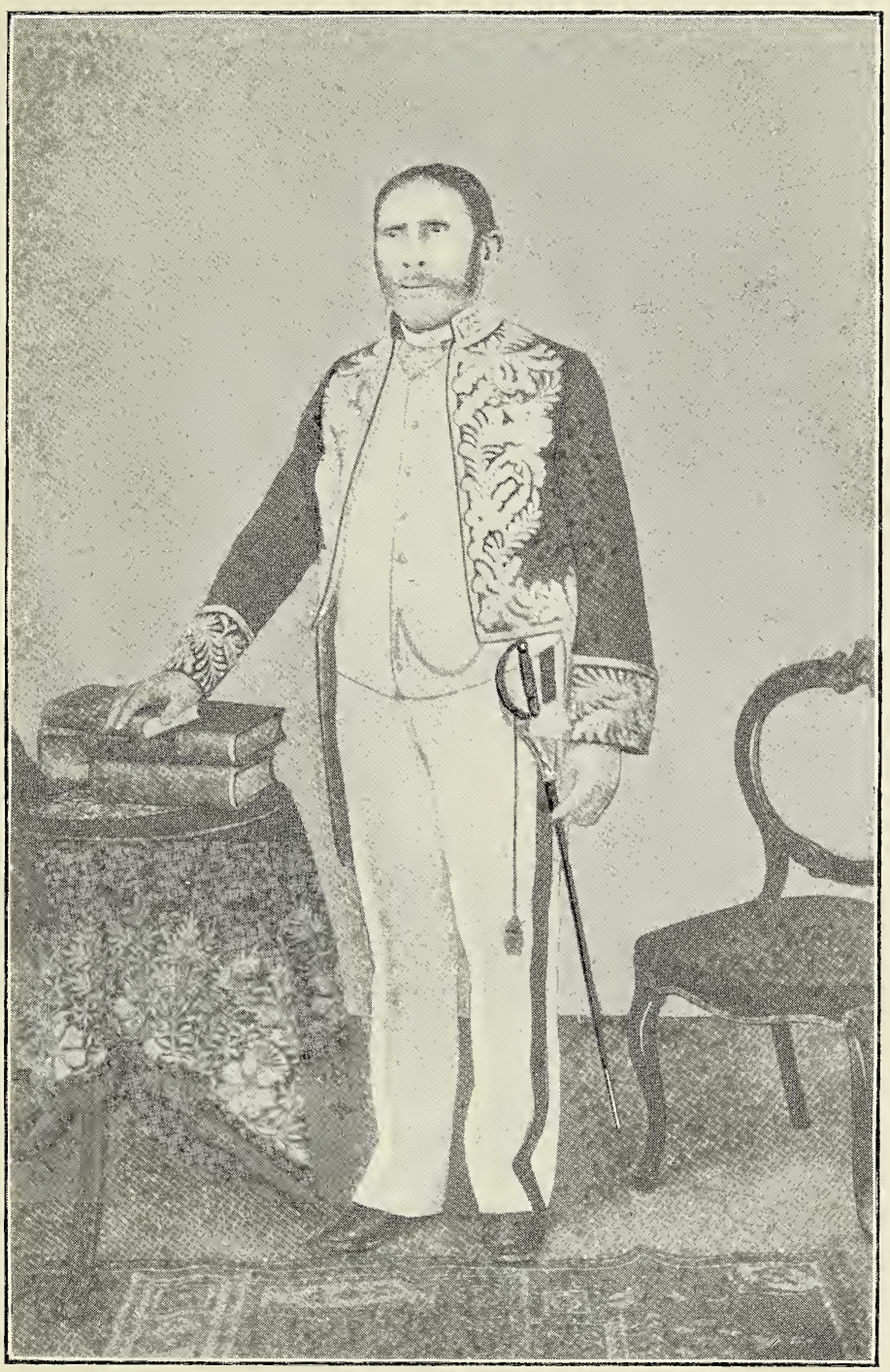

RAINANDRIAMAMPANDRY, GOVERNOR OF TAMATAVE. 



\section{Four-fifths Protestants}

the great importance of having suitable men set apart for the work of the pastorate, faithful men able to teach others also, the prospects for the future of the mission will be brighter than ever.

' By their cruel oppression and arrogant pretensions in the early days of the French occupation, the Jesuits overreached themselves, and for ever opened the eyes of the Hovas to their true character.' Since the people have been free to exercise personal choice with regard to religion, they have turned in great numbers to the Protestant places of worship from which they had been forced to withdraw during the days of Jesuit persecution, and now four-fifths of the worshippers are Protestants.

As I have said already, after the annexation and the emancipation of the slaves, but mainly in consequence of the many false reports set in circulation by the Jesuits, the Roman Catholic schools greatly increased and the attendance at the Roman Catholic services. This change was really a great gain to the strength and spirituality of the Protestant churches, as it rid them of numbers of nominal members and adherents, and although progress seemed slower than in former times, it was more real, and what was lost in extension was gained in depth. The French officials showed their partiality for the Roman Catholic Church by making numerous grants of land for education and other purposes in Antanànarivo, its neighbourhood, and elsewhere. That some partiality and favour may be shown from time to time in such matters is to be looked for; but the facts remain that four-fifths of the people of Imèrina and the Bètsilèo country are Protestants, and that the Jesuits have less power and influence to-day than they had before the war.

M. Bianquis, of the Paris Missionary Society, in a com- 
prehensive review of the present situation in Madagascar says: 'Our earliest missionaries thought that it would suffice for us to be the protectors and guarantors, in the eyes of the French officials, of the English and Norwegian missionaries. But time has cleared these brethren from the calumnies with which they had been charged. The dignity of their life, their absolute political rectitude, and the undeniable part which they are playing in the civilization of the colony have assured to them all the countenance they need for the peaceful continuance of their work.'

" "Then had the churches rest ... and were edified; and walking in the fear of the Lord, and in the comfort of the Holy Ghost, were multiplied "; in some such terms might the peaceful progress of the Malagasy churches of to-day be described. The period of mistrust and suspicion with which those associated with the Society were regarded has ended, and the French Republic recognizes the loyalty of the Protestant native churches, and frankly accepts the labours of the British missionaries as contributing to the progress and enlightenment of their new possession. No word of complaint now reaches us. For the relief thus secured we can hardly be too thankful.'

Thus through God's overruling providence the London Missionary Society's Mission has been released from a perilous position, and placed again on a footing of freedom and hopefulness, and if this new and better policy continues-as it seems likely to do-the London Missionary Society and other missionaries may look forward to many years of useful and successful labour in the cause of Christ on the island.

The Imèrina Mission of the London Missionary Society may be in want of much to thoroughly fit it to face the 


\section{Some Results of Work}

future, and meet and master the many difficulties which are certain to arise under the new régime; but what is most needed - as in hundreds of the churches at home-is an increase of evangelical piety and fervour, and with it a revival of moral earnestness and missionary enthusiasm, which will make itself felt in the Christian work at home and abroad.

This cannot be the outcome of cold-blooded ethical teaching, empty platitudes- ' toothless generalities,' as some one has called them-or of sensational preaching, the sort of sermon which only entertains and pleases, while it leaves the sinner's conscience at ease. These, like mere intellectual preaching, are among the abominations that make desolate the soul. The preaching and teaching of the Gospel of Jesus Christ can alone generate the earnestness, enthusiasm, and zeal needful to carry on successfully His work, and raise men up, whether at home or abroad, to the measure of the stature of His perfect manhood.

When the French arrived in 1895 we had 1,300 selfsupporting Christian churches or preaching stations, I,000 native pastors, some 6,000 local preachers, 80,000 church members, 280,000 adherents, 800 day schools, with 80,000 children in them, and 400 Sabbath schools with 20,000 scholars. From the burning of the idols in September, $\mathbf{1 8 6 9}$, to 1895 , the people had raised for religious purposes upwards of $£ 70,000$, which, seeing that money was five times the value to them it was to us, really represented some $£_{350,000 !}$ !nd yet there are still some ignorant, thoughtless people who talk of foreign missions being a failure. If that is a failure, I hope God in His goodness will give us a repetition of such failures all over the mission field, and we shall be profoundly thankful. 


\section{The Triumph of the Gospel}

It is only fair, however, to the public to say that it is only the grossly ignorant, or the prejudiced, and those more accustomed to speak than to think, that indulge in such statements. Foreign missions have not been a failure, but a great success in Central and Southern Madagascar, in Manchuria, in Livingstonia, in India (recent critics, a certain class of Anglo-Indians and travellers notwithstanding), in China (as 4,000 Chinese converts dying for their faith proved), on the Congo, in New Guinea, in the South Seas, and in South America.

Some cynic has sneeringly remarked that 'nothing is so false as facts, except figures.' Statistics, however, can do a good deal, but they can never convey a really accurate impression of the true results of mission work. Facts and figures can tell much; but they do not and cannot tell folks' feelings, nor can they even tell all they imply.

Foreign missions properly conducted can never be a failure: that is a moral impossibility; for that means the failure of Christianity. Professing Christians may fail to realize their privileges and their responsibilities, and so fail in their duty to the work of extending the kingdom of Christ to the ends of the earth, and thus fail to carry out the divine command: 'Go ye into all the world, and preach the Gospel to every creature'; but foreign missions can never be a failure. Bishop Butler taught us, even in student days, that it was a moral impossibility rnat ever evil could be triumphant over good, in a world where God was the moral Governor.

There are still some people, however, who have no belief in foreign missions, or home missions, or missions of any kind. Some say they only believe in home missions, while there are others who are always pitting 


\section{Failure impossible}

home missions against foreign missions, forgetting that they are but the two branches of the same great work.

The late Bishop Brooks of America said that a man who opposed foreign missions in the interests of home missions was like a man who had murdered his own father and then appealed to the judge for mercy because he was an orphan!

Where would we have been, and what would have been the state of our native land to-day, but for foreign missions? Our forefathers the Britons were cannibals. St. Jerome tells of seeing some of them in Gaul when he was a boy; and he says, we are told, that they had great flocks and herds in their own land, but that they preferred a ham of the herdsman to that of any of their flock. These were our ancestors, so that we have little to be proud of, but much to be thankful for which the Gospel brought us-light, liberty, privileges, and blessings we should never have known but for foreign missions.

Foreign missions can never be a failure. Directors may die, princes and great men in the church may fall, and missionaries may be martyred; but the Great Head of the church lives and works. He was dead, but is alive for evermore, and has the keys of death and of Hades. He lives and rules and reigns for ever and ever, and while $\mathrm{He}$ lives and reigns His work must make progress. Amid the wreck of thrones and the falling of dynasties, the revolutions of empires and the death of sovereigns, the onward rush of successive generations, and the march of sweeping centuries, God's work must and shall prevail.

And the work being done now for the extension of the Redeemer's kingdom will not die when the labourers' task is over and they are called home; but 


\section{The Triumph of the Gospel}

will live and bring forth fruit long after the green grass has grown over their graves. 'To live in hearts we leave behind is not to die.' His work must and shall advance until the kingdoms of this world shall have become the kingdoms of our Lord and of His Christ, and they shall hang upon Him all the glory of His Father's house ; and a glorious and blood-bought church shall yet rise from the ruins of this sin-blighted world, and shall come forth ' fair as the moon, clear as the sun, and terrible as an army with banners.' May God hasten it in His time, and help and bless all who are working for that glorious consummation! 


\section{INDEX}

Aepyornis, the, 16 .

Affliction, use of, $\mathbf{1}_{5} 6$.

Almeida, Don F. de, voyage of, I 7 .

Ambàtonakànga (A-kànga), church at, 232 ; state of, 233,273 ; Sabbath school at, 235; state of schools in, 237 ; collections for soldiers, $27 \mathrm{I}$; troubles in, 279; girls' school at, 288 ; kindness of people of, 365 .

Amusements of ehildren, 269 .

Andriamihàja, 26.

Àndrlamònana, story of, 143 .

Andrlanaivoràvèlona, Pastor $\mathrm{J}$., work of, $25 \circ$; banishment of, 346.

Andriantàvy, Pastor, I3I.

Andrlantsehèno, Pastor J., 266.

Antanànarivo, fall of, 293.

Antsàmpandràno, church at, I69.

Arabs in Madagascar, I5.

Artisans, missionary, 22.

Baptisms, the first, 39 ; forced, II 4 .

Bath, the, festival of, 14 .

Beating, asking for a, 275 .

Bètsilèo Mission, the, 267 .

Bevan, Rev. T., death of, $2 I$.

Bible, the, translation of, mistakes in, II3; first Malagasy, I57; revision of, 248 ; changes in, 249.

Bible-classes, I 45 , I 57 .

Bible teaching, I74.

Blind girl, story of a, I 43 .

Bliss, Miss M. T., 243 .

Boegner, M., visit of, 353 .

Bond, Hon. John, $x 8$.

Boothby, R., book of, 18 .

Boy communicants, I 16 .

Brick-making, 125.

Brigands, 276.

British treaty with France, 286.

Bullock, a, presented, 189 .

Burglars, 276.

Burning of martyrs, 56 .
Cameron, Mr. J., on soap-making, 35 ; story of, 38 ; quoted, 85 .

Carpenters, dispute with, I 30.

Cases, the question of, 209 .

Catechism, the, translation of, 244 .

Catechizing, I93.

Cave, the, 50.

Certificates, use of, ro6.

Chapel royal, the, 77 .

Charms, native, $3 \mathrm{I}, 223$.

Chief, case of a poor, 219.

Children's Scripture Mission formed, 237.

Chloroform, use of, rog.

Conscription, 180 ; anecdote of, 181 .

Contributions of native church, 220, 226, 271.

Cousins, Rev. W. E., quoted, 69, 70 , $74,76,77,86,9$ r, 186 .

Criminals, treatment of, 66 .

Crucifixion, punishment of, 24 .

D'A brew, J. G., I 7.

Dead, burial of the, 202.

Delirium, native, 223 .

Dentistry, 107, I5I.

Diaz, Bartholomew, $x 6$.

Discipline, church, 93, 272, 275 .

Disease, native views of, 223 .

Divorce, cases of, 34 , I 35 .

Divorce of trade, the, IIr.

Doll prizes, 269.

Drainage, 97 .

Dress, the question of, $\mathrm{IO}_{4}$.

Drink, question of the, 179 .

Duchesne, General, expedition of, 292 ; conquest of the capital by, 293; character of, 301 ; recall of, 305 .

Edresi, writings of, 15 .

Education, progress of, 39 , ror, 163 . Ellis, Rev. W., visit of, 62,63 .

Emancipation of the slaves, $3 \circ 5$.

Escande, Pasteur B., on shooting of 
natives, 325 sq.; murder of, 353 , $35^{8}$.

Examinations, school, I 78 .

Fanompdana, the, I 30 .

Fàravòhitra, martyrdoms at, $5 \%$.

Farquhar, Sir R., I9.

Fees, a question of, I 5 I.

Feudal service, 130 .

Fever, malarial, 95,99; ravages of, 22 I

Fihàonana, mission at, 96,99 ; school at, 174 .

Freebooters, I Io.

French, the, difficulties with, 239 ; banished the island, 240 ; treaty with, 280; disputes with, 291 ; expeditionary force sent to the island, 292 ; free the slaves, 305 ; rising against, 307 ; subjugation of the island by, 3I2; severe policy of, 3I4; conduct towards the London Missionary Society, 3I6; murders by, 324 ; take over the island, 355 ; present policy of, 361 ; administra. tion of, 369 .

French corporal, story of a, $36_{5}$.

Frere, Sir Bartle, visit of, 106.

Funerals, native, 202 ; expenses of, 227.

Gallieni, General, rule of, $31_{4}$; character of, 317 ; his opinion of mission work, 318 ; his proclamation banishing the queen, 355 .

Gilpin, Miss H., work of, I75, 243.

Girl, native, story of, I75.

Girls' school, difficulties of, 2 I 5 .

Gore-Jones, Admiral, visit of, 229.

Government service, I 30.

Griffiths, Mr. D., 47.

Hammond, W., book of, I8.

Hastie, Mr., first British Consul, 20.

Heat, the, 227.

Heathen revenge, $\mathbf{3 2} 3$.

Heathenism, character of, 28 .

Horse-boy, story of a, 360 .

Horses, I 49.

Hova sovereigns, authority of, $3 \mathbf{2}_{2}$; officials, character of, 373 .

Hovas, history of, I 5 ; immorality of, I I I ; politeness of, I I 2 ; respect for the dead, I37.

Husband and wife question, a, II 5 .

Huts, native, I 29.
Hymns and tunes, 184 .

Idol, royal, burnt, 78 .

Ile Dauphiné, 17 .

Immorality, native, IIo, $37 \mathrm{I}$.

Infanticide, 32.

Interpreter, treachery of, 229.

Jesuit priests, conduct of, I02, 241 ; deceit of, 321 .

Johnson, Captain, conduct of, 246.

Johnson, W. and L., murder of, 302 . Jones, Rev. D., first missionary, 21.

Knife prizes, 269.

Laborde, M. 70.

Lamba, use of, 202.

Lambert, M., 70 .

Language reduced to writing, 23 ; softness of, 62 .

Laroche, M., character of, $3 \circ 5$; frees the slaves, 305 .

Laurence, St., island of, I 7 .

Le Sage, mission of, 20.

Legacy, the first, to the church, 203.

Lightning, struck by, 217 .

Livingstone, Dr., quoted, I 33 .

Local preacher, a, sermon of, $9^{2}$; a strange, 105 ; story of a, 367 .

Losses caused by the rebellion against the French, 3II; by French excesses, 323 .

Lovett, Rev. R., quoted, 45, 47, 52, $63,70$.

Lucky days, 32 .

Madagascar, description of, I3 ; Jews' connexion with, 14 ; tribes in, I 5 ; Arabs in, 15; French intercourse with, 17 ; etymology of, 17 ; slave trade in, I9; orgies in, 24; immorality in, 24, 1 10 ; beliefs in, 29 ; proverbs in, 30 ; superstition in, 31 ; scenery of, 84; slavery in, 109 ; progress of Christianity in, 138 ; becomes a French colony, 355; church statistics of, 377 .

Magaster, I6.

Malagasy, family names of, 270 ; present state of, 274 ; traits of, 281 ; conduct of, 297 ; improvement in morals of, $37 \mathrm{I}$.

Manse built, 125 . 


\section{Index}

Marco Polo, work of, 16.

Marriage, native views of, 206.

Married things, 184 .

Martyr Memorial Church, building of, $15^{8}$; opening of, 186; mending floor of, 196 .

Martyrdoms, the first, 45 .

Matthews, Rev. T. T., sent out, 82 ; journey to the capital, 83 ; illness of, 87 ; visits Vonizongo, 94 ; builds a house, 96 ; first Sabbath at Fibàonana, roo; mission work of, 102 ; his medical work, 107, 118 ; surgical operations, 108; work on, language, III; cases of advice, II4; visit to the capital, 123; goes back to station, $x_{23}$; difficnlty with palanquinbearers, 123 ; builds a manse, 125 ; his palanquin-bearers, 150 ; a quick journey, I 54; a trying journey, I54; illness of, 160 ; itineration by, 172 ; turned out of bed, $I_{72}$; opens Martyr Memorial Church, 186 ; on slavery, 190; school built, 198; attacked by fever, 208; school work, 2I 3 ; marvellous escape from lightning, 217 ; heat-apoplexy, 227 ; return to the island, 230 ; goes to Akanga, 233; becomes member of Revision Committee, 248; visits Bètsilèo Mission, 267 ; acts as gatekeeper, 268 ; attacked by robbers, 276 ; his literary work, 362 .

Matthews, Mrs., illness of, 99 ; starts a sewing-class, Ior, 145 ; accident to, 153 ; illness of, 160,216 ; escape from lightning, 218 .

Matthews, Miss, work of, 288 .

Medical work, 107.

Miller, Hugh, quoted, 278 .

Minault, Pasteur, murder of, $353,35^{8}$.

Mistakes in language by missionaries, II 2.

Moon-stroke, 227.

Mullens, Rev. Dr., visit of, 98 ; on school work, I62; on Razàka, 263.

Native agents, importance of, $\mathrm{r}_{44}$.

New Testaments and the Customs, $36 \%$.

Normal school, the, 166 .

Nurses, trained, I95.

Old disciple, I $4^{2}$.

Ophir, 14 .
Pakenham, Mr., 70.

Palace Church Evangelist, conduct of, IIg.

Palanquin-bearers, difficulty with, I23; strike among, 150.

Paris Missionary Society, work of, $35^{2}$.

Pastorate, the native, 374 .

Persecution, the first, 42 .

Pigs, 97 ; adventure with, 172 .

Pilkington, Colonel $R_{\text {, }}$ gift of, 199 .

Pillans, Rev. J., visit of, 98 .

Powell, Dr., 47.

'Praying,' 42.

Proclamation on education, 162 ; of freedom, $2 \times 6$.

Proverbs, Malagasy, 30.

Quarterly meetings, 174 ; vigour of, 215 . Questions put to converts, 54 ; curious, 92.

Quinine, sale of, 178 ; use of, 222.

Radàma I, reign of, 20.

Radàma II, reign of, 69 ; character of, 71 ; death of, 72 .

Rafàralàhy, story of, 46 .

Rafàravàvy, story of, 43 .

Rafàravàvy Maria, story of, 49 .

Rainiàsivòla, death of, 58 .

Rainihàrisò, robbery of, 302 .

Rainilaiàrivòny, deposition of, 300 .

Rainitslandàvaka, 27 .

Rakòtobè, 26.

Rakòtovào, story of, ror.

Ramàrindàlana, death of, 56 .

Ràmitràha, story of, $5 \mathrm{r}, 60$.

Rànavàlona $I$, reign of, 26 ; character of, $25,27,39,68$; death of, 26,65 ; on soap-making, 35 ; her edict against Christianity, 42 ; her cruelty, 66.

Rànavàlona II, reign of, 74; policy of, 75 ; founds a chapel royal, 77 ; a nursing-mother of the church, 203 ; judgement of, 205 ; death of, 243 .

Rànavàlona III, reign of, 243 ; deception practised on, 296 ; surrender of, 300 ; banishment of, 346 ; arrest of, 352 ; banished to Bourbon, 353 , 356 .

Rànivo, death of, 59 .

Ràsalàma, story of, 44 .

Ràsohèrina I, reign of, $7^{2}$; her tolerant policy, 72 ; death of, 74 . 
Ràsomoèly, death of, 283 .

Razàka, story of, $5 \circ$; baptism of, $6 \mathrm{I}$; his use of the Bible, 62 ; liberation of, 67 ; character of, $25 \mathrm{I}$; story of, 254 ; death of, 265.

Reading-classes, 208.

Religious Tract Society, grants of, $3^{6} 4$.

Revival in the capital, 287.

Rising against the French, 307; sufferings caused by, $3 \mathrm{II}$.

Robbers, IIO.

Rock, the Tarpeian, 57.

Roman Catholic missionaries compared with Protestant, 23 ; priests, policy of, 69 ; persecution of native converts by, 325 sq.; increase of, 375 .

Sabbath desecration, 272 .

Sabbath worship, $76,78,100$.

Sàkalàvas, the, 245 .

Salaries of native pastors, 207.

Saluting the fowls, 223 .

Schools, statistics of, 39 ; starting of, IOI ; village, state of, $16 \mathrm{I}$; state of, I93 ; statistics of, 195 ; building of, 198 ; progress of, 213 .

Scriptures, the, translation of, 23,29 , 40.

Sewell, J., visit of, rgo.

Sewing-class started, IOI, I45.

Sheep's rump, the, 206.

Shoemaker, story of a native, 367 .

Singing-classes, 183 .

Slave trade, I9; abolished, 20.

Slaves, position of, I09; native opinion of, 190 ; emancipation of, 216 ; decree of freedom for, 305 .

Small-pox, visitation of, 224 .

Soap question, the, 35 .

Soldier-schoolmasters, $\mathrm{I}_{4}$.
Soldiers, runaway, 109.

Soot, 270.

Spicer, Alderman Evan, visit of, 362 .

Squire-pastors, 140.

Statistics, church, 3I 7 .

Stoning, death by, 64 .

Storm, fearful, 217 .

Tàmatàve, blockade of, 246 .

Teacher, honesty of a native, 285 .

Teachers, native, I64.

Ten Years' Review, quoted, 29 I.

Thompson, Rev. R. Wardlaw, visit of, 362 .

Thrashed to church, 119.

Traitors, native, 297 .

Translation work, $23,29,40,363$.

Travellers' tales, 173 .

Tunes and hymns, 184 .

Turning of the dead, 202.

Vaccination, 224.

Vanderkemp, Dr., visit of, 2 I.

Vasco da Gama, I6.

Victoria, Queen, message of, $\mathbf{7 3}$.

Vilers, M. Le Myre, 29 I.

Vònizòngo, mission work in, 48 ; examination of converts in, 54 ; description of, 88 ; mission work in, $9^{\circ}$; state of people of, I 20.

Wages, native, $\mathbf{2} 28$.

Wives of missionaries, their work, 147 . Women, position of, 34 ; services for, 267.

Wreck of churches, 323 .

Writing, introduction of, 23 .

Zànakàntitra, the, conspiracy of, $3 \circ 3$. 


6 
